DANIELLA CRISTINA BARBOSA DE LIRA

ESTUDO DE DEGRADAÇÃO FOTOQUÍMICA PARA REÚSO DE ÁGUAS DE PROCEŞSO EM COMPLEXO INDUSTRIAL PETROQUÍMICO 
DANIELLA CRISTINA BARBOSA DE LIRA

\section{ESTUDO DE DEGRADAÇÃO FOTOQUÍMICA PARA REÚSO DE ÁGUAS DE PROCESSO EM COMPLEXO INDUSTRIAL PETROQUÍMICO}

Dissertação apresentada à Escola Politécnica da Universidade de São Paulo para a obtenção do título de Mestre em Engenharia 
DANIELLA CRISTINA BARBOSA DE LIRA

\section{ESTUDO DE DEGRADAÇÃO FOTOQUÍMICA PARA REÚSO DE ÁGUAS DE PROCESSO EM COMPLEXO INDUSTRIAL PETROQUÍMICO}

Dissertação apresentada à Escola Politécnica da Universidade de São Paulo para a obtenção do título de Mestre em Engenharia

Área de Concentração:

Engenharia Química

Orientador:

Prof. Dr. Roberto Guardani 


\section{AGRADECIMENTOS}

Ao meu pai e à minha mãe por sempre acreditarem no meu potencial, respeitarem as minhas decisões e apoiarem nos momentos mais difíceis.

Ao meu irmão, a quem admiro muito.

Ao meu grande e eterno companheiro Carlos, por toda paciência, incentivo e amor.

Ao Departamento de Engenharia Química da Escola Politécnica da USP, à FINEP, ao CTHidro e à empresa Suzano Petroquímica que viabilizaram a oportunidade para o desenvolvimento do tema desse trabalho cujo objetivo é a racionalização do uso da água na indústria.

Ao Laboratório de Simulação e Controle de Processos (LSCP) que me acolheu e me abasteceu do conhecimento e infra-estrutura necessários para a completa realização dessa dissertação.

À Dra. Isabela Will, amiga e companheira de trabalho, pela importantíssima ajuda na parte experimental, no desenvolvimento da metodologia e na elaboração de trabalhos científicos. Acima de tudo, pelo comprometimento e otimismo.

A todos os amigos do grupo de fotoquímica, que concorreram para o crescimento deste trabalho.

Aos meus amigos que ingressaram junto comigo no programa de mestrado: Cínthia, Verônica, Patrícia, Wilson e Juliana, com quem estudei as disciplinas e troquei idéias. Nos momentos de descontração, eles também foram muito importantes.

Elaborei esta dissertação com muita dedicação. Mas apenas dedicação não bastou para atingir um excelente resultado, a orientação foi fundamental. Por isso, agradeço ao meu orientador Prof. Dr. Roberto Guardani e também ao Prof. Dr. Cláudio Oller.

A Capes pelo apoio financeiro. 


\section{RESUMO}

A racionalização dos recursos hídricos tem sido uma das metas das indústrias em vários setores. Tais metas exigem inovações tecnológicas tanto para novos processos produtivos quanto para novas técnicas de tratamento e reutilização de água na cadeia de produção. Os custos elevados de água industrial no Brasil, particularmente nas regiões metropolitanas, têm estimulado as indústrias nacionais a avaliar as possibilidades de reúso.

O objetivo deste trabalho é a aplicação do tratamento de águas de processo contendo polipropileno utilizando radiação ultravioleta e peróxido de hidrogênio, isto é, o sistema $\mathrm{UV} / \mathrm{H}_{2} \mathrm{O}_{2}$, visando adequá-las para reúso no próprio processo, reduzindo a necessidade de captação de água pré-tratada e de descarte de efluente. A primeira parte do estudo consistiu na realização de experimentos em um sistema fotoquímico de batelada, empregando quatro diferentes correntes efluentes de processo, para a avaliação da viabilidade técnico-econômica do tratamento fotoquímico, bem como para a obtenção de dados referentes à cinética das reações fotoquímicas. Com base nas informações obtidas, na segunda parte do estudo foram realizados experimentos em um sistema fotoquímico contínuo, a fim de obter dados para o aumento de escala para aplicação industrial do processo de tratamento contínuo.

Os resultados experimentais indicaram a viabilidade técnica de aplicação do sistema $\mathrm{UV} / \mathrm{H}_{2} \mathrm{O}_{2}$ utilizando fonte de luz artificial para todas as correntes de processo estudadas, tendo sido alcançados níveis de remoção de matéria orgânica acima de $90 \%$. No entanto, sob o ponto de vista econômico, apenas as correntes com baixo teor de carbono orgânico total dissolvido (COT), entre 6 e $12 \mathrm{mgC} \mathrm{L}^{-1}$, mostraram-se adequadas ao reúso, após o tratamento.

Palavras-chave: Reúso. Sistema $\mathrm{UV} / \mathrm{H}_{2} \mathrm{O}_{2}$. Tratamento de efluentes industriais. Processo Oxidativo Avançado. Distribuição de tempos de residência. Rede neural. 


\section{ABSTRACT}

Rationalization of water use has been one of the goals in many industrial activities, and, in particular, in the petrochemical industry. Such goals demand technological innovations in the productive processes and in techniques for treatment and reuse of water in the production chain. The high costs of industrial water, particularly in some metropolitan regions, have stimulated the industries to evaluate the possibilities of water reuse.

The objective of this work is to evaluate the feasibility of the $U V / \mathrm{H}_{2} \mathrm{O}_{2}$ photochemical process applied to the treatment of process waste water containing polypropylene, aiming at the reuse of the waste water in the as process water in the industrial complex, thus reducing the need for tap water supply and waste water generation rate. The first part of this study consisted of laboratory-scale experiments in a batch photochemical reactor with four different waste water streams to perform the technical and economical feasibility of the photochemical treatment, as well to obtain data on the degradation rate. Based on the results of the first part, the second part of this study consisted of experiments in a continuous photochemical reactor, aimed at obtaining experimental data for reactor scale-up.

Experimental results indicate that the $\mathrm{UV} / \mathrm{H}_{2} \mathrm{O}_{2}$ photodegradation process is able to remove more than $90 \%$ of the organic compounds contained in the waste water. However, only waste waters containing relatively low contaminant levels (between 6 and $12 \mathrm{mgC} \mathrm{L}^{-1}$ ) can be treated at economically favourable costs.

Keywords: Water Reuse. UV/ $\mathrm{H}_{2} \mathrm{O}_{2}$ photochemical process. Industrial waste water treatment. Advanced Oxidation Process. Residence time distribution. Neural Network. 


\section{LISTA DE TABELAS}

Tabela 1 - Classificação das modalidades de reúso e suas respectivas ocorrências

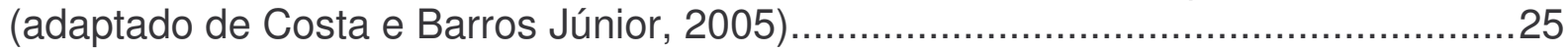

Tabela 2 - Aplicações da Água Reciclada (adaptado de FIESP e CIESP, 2004).....25

Tabela 3 - Processos e operações unitárias usadas em tratamento de águas ........29

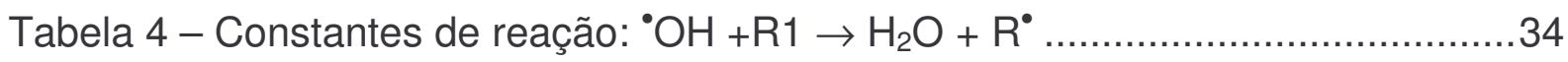

Tabela 5 - Exemplos de processos térmicos e induzidos por luz para a produção de radicais hidroxila (adaptado de Will, 1998 e Teixeira e Jardim, 2004).

Tabela 6 - Revisão bibliográfica sobre os processos oxidativos avançados aplicados ao reúso de efluentes.

Tabela 7 - Parâmetros de processos que afetam o sistema UV/ $\mathrm{H}_{2} \mathrm{O}_{2} \ldots \ldots \ldots \ldots \ldots \ldots . . . . . .40$

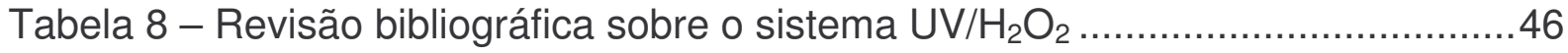

Tabela 9 - Tratamento de águas contaminadas através de sistemas $U V / \mathrm{H}_{2} \mathrm{O}_{2}$ comerciais (Adaptado de EPA, 1998) …......................................................... 51

Tabela 10 - Estudos de reatores contínuos para o sistema $\mathrm{UV} / \mathrm{H}_{2} \mathrm{O}_{2} \ldots \ldots \ldots \ldots \ldots \ldots . . . . . . .54$

Tabela 11 - Caracterização dos efluentes estudados........................................61

Tabela 12 - Quadro comparativo de métodos de injeção ..................................65

Tabela 13 - Teores mássicos $(\mathrm{m} / \mathrm{m})$ das soluções de peróxido de hidrogênio

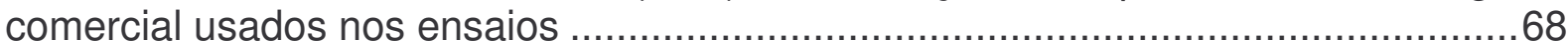

Tabela 14 - Densidade das soluções de peróxido de hidrogênio em função do teor mássico

Tabela 15 - Variáveis investigadas e seus respectivos valores

Tabela 16 - Condições experimentais e percentuais de remoção de carbono orgânico (Eq. 29 ) para os experimentos de tratamento do efluente E1 por sistema $\mathrm{UV} / \mathrm{H}_{2} \mathrm{O}_{2}$.

Tabela 17 - Condições experimentais e percentuais de remoção de carbono orgânico (Eq. 29 ) para os experimentos de tratamento do efluente E2 por sistema $\mathrm{UV} / \mathrm{H}_{2} \mathrm{O}_{2}$.

Tabela 18 - Condições experimentais e percentuais de remoção de carbono orgânico (Eq. 29 ) para os experimentos de tratamento do efluente E3 por sistema $\mathrm{UV} / \mathrm{H}_{2} \mathrm{O}_{2}$.

Tabela 19 - Condições experimentais e percentuais de remoção de carbono orgânico (Eq. 29 ) para os experimentos de tratamento do efluente E4 por sistema $\mathrm{UV} / \mathrm{H}_{2} \mathrm{O}_{2}$

Tabela 20 -Valores mínimos e máximos para as variáveis de entrada e saída......103

Tabela 21 - Parâmetros/Características das redes obtidas

Tabela 22 - Pesos da rede neural (LS) ajustada para modelo $\mathrm{M}-1(\mathrm{NH}=6 ; \mathrm{NI}=10000)$

Tabela 23 - Pesos da rede neural (LS) ajustada para modelo $\mathrm{M}-2(\mathrm{NH}=5 ; \mathrm{NI}=10000)$ 
Tabela 24 - Pesos da rede neural (LS) ajustada para modelo $\mathrm{M}-3(\mathrm{NH}=7 ; \mathrm{Nl}=10000)$ 108

Tabela 25 - Parâmetros/Características da rede obtida para modelo M-1a 111

Tabela 26 - Pesos da rede neural (LS) ajustada para modelo $\mathrm{M}-1 \mathrm{a}$ ( $\mathrm{NH}=6$; $\mathrm{Nl}=10000)$

Tabela 27 - Condições dos ensaios de DTR e características das curvas obtidas no reator contínuo para vazões entre 10 e $90 \mathrm{~L} / \mathrm{h}$. 115

Tabela 28 - Desvio padrão e coeficiente de variação das vazões ensaiadas 117

Tabela 29 - Determinação do volume útil do reator em função da vazão. 118

Tabela 30 - Determinação do desvio padrão de $\mathrm{T}-\mathrm{d}_{\mathrm{p}}(\mathrm{T})$ 119

Tabela 31 - Volumes estimados para a zona morta 121

Tabela 32 - Condições dos experimentos contínuos. 123

Tabela 33 - Plano de experimentos Doehlert 124

Tabela 34 - Condições experimentais dos ensaios realizados no reator continuo 124 Tabela 35 - ANOVA para o modelo proposto $\left(\Delta C O T=b_{0}+b_{1} x_{1}+b_{2} x_{2}+b_{11} x_{1}+\right.$ $\left.\mathrm{b}_{22} \mathrm{x}_{2}+\mathrm{b}_{12} \mathrm{x}_{1} \mathrm{x}_{2}\right)$

Tabela 36 - Resultados de COT versus tempo medidos no $4^{\circ}$ compartimento para os ensaios no ponto central 


\section{LISTA DE FIGURAS}

Figura 1 - Circuito de águas atual (a); Circuito de águas proposto (b). Vazão de

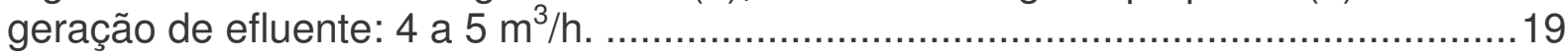

Figura 2 - Vazões de consumo de água para os diferentes usos no Brasil, vazão de

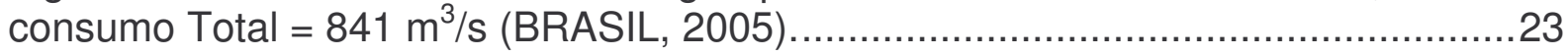

Figura 3 - Mapa tecnológico: tratamentos de efluentes classificados em função do COT (carbono orgânico total) presente em efluentes e vazões volumétricas de efluentes gerados (adaptado de HANCOCK, 1999).

Figura 4 - Coeficiente de extinção molar $\varepsilon_{\mathrm{H} 2 \mathrm{O} 2}\left(\mathrm{M}^{-1} \mathrm{~cm}^{-1}\right)$ em função do comprimento de onda (nm) (EPA, 1998).

Figura 5 - Curvas típicas de distribuição espectral de energia: $(-)$ lâmpada a vapor de mercúrio de baixa pressão - monocromática (TUV - Philips); (-) lâmpada a vapor de mercúrio de média pressão - policromática (Hanovia - Ace Glass). ...........44

Figura 6 - Esquema do reator fotoquímico em escala de bancada. ........................56

Figura 7 - Foto do reator fotoquímico em escala de bancada

Figura 8 - Espectro de transmissão do poço de quartzo encamisado do reator

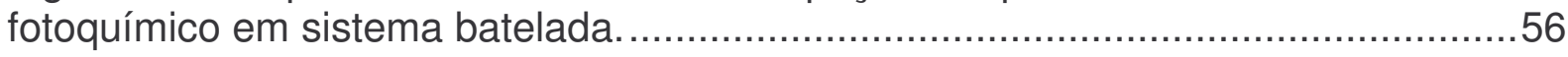

Figura 9 - Desenho esquemático do reator fotoquímico contínuo. .57

Figura 10 - Desenho esquemático do escoamento no interior do reator fotoquímico contínuo.

Figura 11 - Sistema do reator multilâmpadas. O reator pode ser operado de forma contínua (linha verde) ou em batelada (linha vermelha) ........................................58

Figura 12 - Foto do reator contínuo fotoquímico................................................59

Figura 13 - Foto do sistema do reator contínuo fotoquímico ..................................59

Figura 14 - Foto do reator contínuo fotoquímico mostrando em detalhe o sistema de amostragem. 60

Figura 15 - Pontos de coleta dos efluentes investigados, indicados pelos círculos..61

Figura 16 - Valores de COT。 (carbono orgânico total inicial) versus tempo de armazenamento dos efluentes coletados em abril/2004, COTo medido após filtração. (a) efluente E1, (b) efluente E2, (c) efluente E3 e (d) efluente E4 ............................62

Figura 17 - Curva de calibração do traçador (azul de metileno)..............................66

Figura 18 - Modelo não-linear de um neurônio artificial........................................70

Figura 19 - Estrutura de uma rede neural artificial (RNA) do tipo "feedforward" com

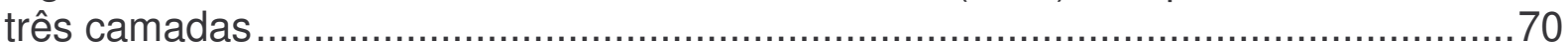

Figura 20 - Representações esquemáticas de $E(\theta)$ para a injeção de um pulso perfeito. (Adaptado de Levenspiel, 1974)..............................................................73

Figura 21 - Erro na medida de COT em função dos valores médios.........................76

Figura 22 - Ensaios preliminares para efluente E1 (baixo teor de matéria orgânica). As condições experimentais são indicadas na tabela. Gráfico à esquerda: resultados não normalizados; gráfico à direita: resultados normalizados. 
Figura 23 - Ensaios preliminares para efluente E1 (baixo teor de matéria orgânica). As condições experimentais estão indicadas ao lado da figura.

Figura 24 - Ensaios preliminares para efluente E2 (baixo teor de matéria orgânica). As condições experimentais são indicadas na tabela. Gráfico à esquerda: resultados não normalizados; gráfico à direita: resultados normalizados.

Figura 25 - Ensaios preliminares para efluente E3 (baixo teor de matéria orgânica). As condições experimentais são indicadas na tabela. Gráfico à esquerda: resultados não normalizados; gráfico à direita: resultados normalizados.

Figura 26 - Ensaios preliminares para efluente E4 (alto teor de matéria orgânica). As condições experimentais são indicadas na tabela. Gráfico à esquerda: resultados não normalizados; gráfico à direita: resultados normalizados.

Figura 27 - Forma de adição de peróxido. Condições experimentais: Efluente E3; $\mathrm{P}=$ 400W; em 4 partes $(0,15,30$ e $45 \mathrm{~min}):\left[\mathrm{H}_{2} \mathrm{O}_{2}\right]=6,5 \mathrm{mM}, \mathrm{COT}_{0}=24 \mathrm{mgC} \mathrm{L}^{-1}, \alpha=9$, $\mathrm{T}=50^{\circ} \mathrm{C}$; início: $\left[\mathrm{H}_{2} \mathrm{O}_{2}\right]=3,3 \mathrm{mM}, \mathrm{COT}_{0}=18 \mathrm{mgC} \mathrm{L}^{-1}, \alpha=6, \mathrm{~T}=30^{\circ} \mathrm{C}$

Figura 28 - Experimento na ausência de luz. Condições experimentais: efluente E3; adição de $\mathrm{H}_{2} \mathrm{O}_{2}$ no início; $\left[\mathrm{H}_{2} \mathrm{O}_{2}\right]_{0}=6,9 \mathrm{mM} ; \mathrm{COT}_{0}=4 \mathrm{mgC} \mathrm{L}^{-1} ; \alpha=60 ; \mathrm{T}=30^{\circ} \mathrm{C}$. Barra de erro: $\pm 0,20 \mathrm{mgC} \mathrm{L}^{-1}$. Intervalo de confiança para média de $95 \%: \pm 0,11 \mathrm{mgC} \mathrm{L}^{-1} .80$

Figura 29 - Remoção de matéria orgânica durante tratamento de efluente E1 por sistema $U V / \mathrm{H}_{2} \mathrm{O}_{2}$, para diferentes potências de lâmpadas. Experimentos $\mathrm{BE} 1-13$, BE1-14, BE1-15 e BE1-16, cujas condições experimentais estão apresentadas na Tabela 16. $\left(\mathrm{COT}_{0}=7,7 \mathrm{mgC} \mathrm{L}^{-1}, \alpha=9, \mathrm{~T}=30^{\circ} \mathrm{C}\right)$

Figura 30 - Remoção de COT após 20 minutos de reação $\left(\mathrm{X}_{20}\right)$ versus Potência da lâmpada para efluente E1. Experimentos BE1-13, BE1-14, BE1-15 e BE1-16.........84

Figura 31 - Remoção de matéria orgânica durante tratamento de efluente E2 por sistema $U V / \mathrm{H}_{2} \mathrm{O}_{2}$, para diferentes potências de lâmpadas. Experimentos BE2-3, BE2-8 e BE2-15, cujas condições experimentais estão apresentadas na Tabela 17 $\left(\alpha=5, T=30^{\circ} \mathrm{C}\right)$. Os dados foram normalizados (figura à direita) devido às diferenças no COT.

Figura 32 - Remoção de COT após 20minutos de reação $\left(X_{20}\right)$ versus Potência da lâmpada para efluente E2. Experimentos BE2-3, BE2-8 e BE2-15.

Figura 33 - Remoção de matéria orgânica durante tratamento de efluente E3 por sistema $\mathrm{UV} / \mathrm{H}_{2} \mathrm{O}_{2}$, para diferentes potências de lâmpadas. Experimentos BE3-2, BE3-6, BE3-12 e BE3-17 cujas condições experimentais estão apresentadas na Tabela $18\left(\alpha \approx 7, T=30^{\circ} \mathrm{C}\right)$. Os dados foram normalizados (figura à direita) devido às diferenças no COTo.

Figura 34 - Remoção de COT após 20 minutos de reação $\left(X_{20}\right)$ versus Potência da lâmpada para efluente E3. Experimentos BE3-2, BE3-6, BE3-12 e BE3-17. .85

Figura 35 - Remoção de matéria orgânica durante tratamento de efluente E4 por sistema $\mathrm{UV} / \mathrm{H}_{2} \mathrm{O}_{2}$, para diferentes potências de lâmpadas. Experimentos BE4-1, BE4-5, BE4-12 e BE4-15 cujas condições experimentais estão apresentadas na Tabela $19\left(\alpha=9, T=30^{\circ} \mathrm{C}\right)$. Os dados foram normalizados (figura à direita) devido às diferenças no $\mathrm{COT}_{0}$.

Figura 36 - Remoção de COT após 120 (20) minutos de reação $\left(X_{120}\right.$ ou $\left.X_{20}\right)$ versus Potência da lâmpada para efluente E4. Experimentos BE4-1, BE4-5, BE4-12 e BE415. 
Figura 37 - Comparação de porcentagem de remoção de COT em função dos efluentes e da potência da lâmpada. Tempo de reação: 20 minutos. $E 1=7,7 \pm 0,2$ $\mathrm{mgC} \mathrm{L}^{-1}$; $\mathrm{E} 2=7,5 \pm 2,1 \mathrm{mgC} \mathrm{L}^{-1}$; E3 = 12,8 $\pm 3,7 \mathrm{mgC} \mathrm{L}^{-1}$ e E4 = $254 \pm 51 \mathrm{mgC} \mathrm{L}^{-1}$.

Figura 38 - Actinometria: taxa de incidência de fótons $P_{\circ}$ (fótons $s^{-1}$ ) em função da potência da lâmpada.

Figura 39 - Curvas de remoção de matéria orgânica no tratamento de efluente E1 por sistema UV/ $\mathrm{H}_{2} \mathrm{O}_{2}$, mostrando o efeito da concentração $\mathrm{H}_{2} \mathrm{O}_{2}$ representada pela razão $\alpha$. Experimentos $\mathrm{BE} 1-10, \mathrm{BE} 1-11, \mathrm{BE} 1-12$ e BE1-13 cujas condições experimentais estão apresentadas na Tabela $16\left(\mathrm{P}=125 \mathrm{~W}, \mathrm{~T}=30^{\circ} \mathrm{C}\right)$. Os dados foram normalizados devido às diferenças no $\mathrm{COT}_{0}$. .88

Figura 40 - Curvas de remoção de matéria orgânica durante tratamento de efluente E2 por sistema UV/ $\mathrm{H}_{2} \mathrm{O}_{2}$, mostrando o efeito da concentração $\mathrm{H}_{2} \mathrm{O}_{2}$ representada pela razão $\alpha$. Experimentos BE2-14, BE2-15, BE2-16 e BE2-17 cujas condições experimentais estão apresentadas na Tabela $17\left(\mathrm{P}=125 \mathrm{~W}, \mathrm{~T}=30^{\circ} \mathrm{C}\right)$. Os dados foram normalizados devido às diferenças no $\mathrm{COT}_{0}$. 88

Figura 41 - Curvas de remoção de matéria orgânica durante tratamento de efluente E3 por sistema UV/ $\mathrm{H}_{2} \mathrm{O}_{2}$, mostrando o efeito da concentração $\mathrm{H}_{2} \mathrm{O}_{2}$ representada pela razão $\alpha$. Experimentos BE3-4, BE3-5 e BE3-6 cujas condições experimentais estão apresentadas na Tabela $18\left(\mathrm{P}=250 \mathrm{~W}, \mathrm{~T}=30^{\circ} \mathrm{C}\right)$. Os dados foram normalizados devido às diferenças no $\mathrm{COT}_{0}$.

Figura 42 - Curvas de remoção de matéria orgânica durante tratamento de efluente E4 por sistema $U V / \mathrm{H}_{2} \mathrm{O}_{2}$, mostrando o efeito da concentração $\mathrm{H}_{2} \mathrm{O}_{2}$ representada pela razão $\alpha$. Experimentos BE4-5 e BE4-6 cujas condições experimentais estão apresentadas na Tabela $19\left(\mathrm{P}=250 \mathrm{~W}, \mathrm{~T}=30^{\circ} \mathrm{C}\right)$. Os dados foram normalizados devido às diferenças no $\mathrm{COT}_{0}$

Figura 43 - Percentual de remoção de COT para $t=20$ min $\left(X_{20}\right)$ e taxa inicial de remoção para $t=20$ min $\left(r_{20}\right)$ em função de dose de $\mathrm{H}_{2} \mathrm{O}_{2}(\alpha)$. .90

Figura 44 - Percentual de remoção de COT para $t=60$ min $\left(X_{60}\right)$ e taxa média de remoção para $t=60$ min $\left(r_{60}\right)$ em função de dose de $\mathrm{H}_{2} \mathrm{O}_{2}(\alpha)$.

Figura 45 - Efeito da temperatura: efluente $\mathrm{E} 1, \mathrm{COT}_{0}=6,9 \mathrm{mgC} \mathrm{L}^{-1}, \mathrm{P}=80 \mathrm{~W}$,

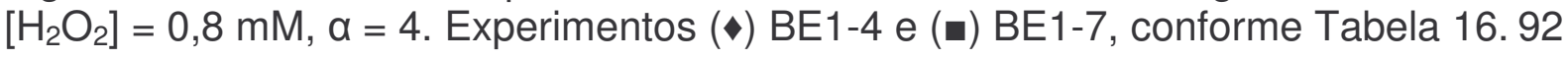
Figura 46 - Efeito da temperatura $(\diamond) 30^{\circ} \mathrm{C}$ e $(\square) 50^{\circ} \mathrm{C}$, efluente E2, COT $=9 \mathrm{mgC} \mathrm{L}$ 1, $P=80$ W. Diagramas (1) $\alpha=8$, Diagramas (2) $\alpha=5$, conforme Tabela 17...........92

Figura 47 - Efeito da temperatura $(\diamond) 30^{\circ} \mathrm{C}$ e ( $50^{\circ} \mathrm{C}$, efluente E3, COT $=14 \mathrm{mgC}$ $\mathrm{L}^{-1}$. Diagramas (1), (2) e (3) $\mathrm{P}=250 \mathrm{~W} ;(4)$, (5) e (6) $\mathrm{P}=80 \mathrm{~W}$. Relação $\alpha=6$ para diagramas (1) e (4), $\alpha=10$ para (2) e (5) e $\alpha=20$ para (3) e (6). Demais condições experimentais conforme Tabela 18.

Figura 48 - Efeito da temperatura $(\diamond) 30^{\circ} \mathrm{C}$ e (匹) 50ㅇ, efluente E4. Diagrama (1) $\mathrm{COT}_{0}=294 \mathrm{mgC} \mathrm{L}^{-1}, \mathrm{P}=250 \mathrm{~W}, \alpha=9$. Diagrama (2) $\mathrm{COT}_{0}=272 \mathrm{mgC} \mathrm{L}^{-1}, \mathrm{P}=250$ $W, \alpha=18$. Demais condições experimentais conforme Tabela 19.......................93

Figura $49-\mathrm{pH}$ versus tempo (min). Experimento B3-14, COTo = $14 \mathrm{mgC} \mathrm{L-1}$,

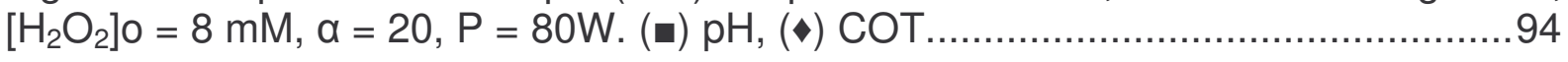

Figura $50-\mathrm{pH}$ versus tempo (min). Experimento B4-12, COT $\mathrm{CO}_{0} 195 \mathrm{mgC} \mathrm{L}^{-1}$, $\left[\mathrm{H}_{2} \mathrm{O}_{2}\right]_{0}=53 \mathrm{mM}, \alpha=9, \mathrm{P}=125 \mathrm{~W}$. (घ) $\mathrm{pH},(\diamond) \mathrm{COT}$. 
Figura $51-\mathrm{pH}$ versus tempo (min). Experimento B4-13, COT $0197 \mathrm{mgC} \mathrm{L}^{-1}$, $\left[\mathrm{H}_{2} \mathrm{O}_{2}\right]_{0}=13 \mathrm{mM}, \alpha=2, \mathrm{P}=80 \mathrm{~W}$. (घ) $\mathrm{pH}$, (») COT.

Figura 52 - Determinação da constante aparente da remoção de COT $\left(\mathrm{k}_{\circ}\right)$ durante 0 tratamento de efluente de baixo e alto COT. Efluente E1 (baixo COT): ( $\square$ ) BE1-13 $\mathrm{k}_{0}=0,09 \mathrm{~min}^{-1}, \mathrm{COT}_{0}=7,8 \mathrm{mgC} \mathrm{L}^{-1}, \mathrm{P}=125 \mathrm{~W},\left[\mathrm{H}_{2} \mathrm{O}_{2}\right]=2,0 \mathrm{mM}, \alpha=9, \mathrm{~T}=30^{\circ} \mathrm{C}$; ( $\mathrm{BE} 1-4 \mathrm{k}_{0}=0,02 \mathrm{~min}^{-1} \mathrm{COT}_{0}=7,6 \mathrm{mgC} \mathrm{L}^{-1}, \mathrm{P}=80 \mathrm{~W},\left[\mathrm{H}_{2} \mathrm{O}_{2}\right]=2,0 \mathrm{mM}, \alpha=9, \mathrm{~T}=30^{\circ} \mathrm{C}$. Efluente E1 (baixo COT): ( $\Delta$ )BE4-3 $\mathrm{k}_{0}=0,01 \mathrm{~min}^{-1} \mathrm{COT}_{\mathrm{o}}=336 \mathrm{mgC} \mathrm{L}^{-1}, \mathrm{P}=400 \mathrm{~W}$, $\left[\mathrm{H}_{2} \mathrm{O}_{2}\right]=41 \mathrm{mM}, \alpha=4, \mathrm{~T}=30^{\circ} \mathrm{C}$; ( $(0) \mathrm{BE} 4-15 \mathrm{k}_{0}=0,01 \mathrm{~min}^{-1} \mathrm{COT}_{0}=204 \mathrm{mgC} \mathrm{L}^{-1}, \mathrm{P}=$ $80 \mathrm{~W},\left[\mathrm{H}_{2} \mathrm{O}_{2}\right]=53 \mathrm{mM}, \alpha=9, \mathrm{~T}=30^{\circ} \mathrm{C}$.

Figura 53 - Custo de tratamento por sistema $\mathrm{UV} / \mathrm{H}_{2} \mathrm{O}_{2}$ versus $\Delta \mathrm{COT}$, efluente $\mathrm{E} 1$, $\mathrm{COT}_{0}=7,7 \mathrm{mgC} \mathrm{L}{ }^{-1}, \alpha=9,\left[\mathrm{H}_{2} \mathrm{O}_{2}\right]_{0}=2,0 \mathrm{mM}, \mathrm{T}=30^{\circ} \mathrm{C}$. Experimentos: BE1-13, $\mathrm{BE} 1-$ 14, BE1-15 e BE1-16.

Figura 54 - Custo de tratamento por sistema $\mathrm{UV} / \mathrm{H}_{2} \mathrm{O}_{2}$ versus $\Delta \mathrm{COT}$, efluente $\mathrm{E} 2$, $\mathrm{COT}_{\circ}=5,3$ a 9,3 mgC L ${ }^{-1}, \alpha=4$ a 5, $\left[\mathrm{H}_{2} \mathrm{O}_{2}\right]_{\circ}=0,8$ a 1,2 mM, $\mathrm{T}=30^{\circ} \mathrm{C}$. Experimentos: BE2-3, BE2-8 e BE2-15.

Figura 55 - Custo de tratamento por sistema $\mathrm{UV} / \mathrm{H}_{2} \mathrm{O}_{2}$ versus $\Delta \mathrm{COT}$, efluente $\mathrm{E} 3$, $\mathrm{COT}_{0}=8,8$ a $17,6 \mathrm{mgC} \mathrm{L}^{-1}, \alpha=6$ a $8,\left[\mathrm{H}_{2} \mathrm{O}_{2}\right]_{\mathrm{o}}=2,2$ a 3,3 mM, T=30ㅇ. Experimentos: BE3-2, BE3-6, BE3-12 e BE3-17.

Figura 56 - Custo de tratamento por sistema $\mathrm{UV} / \mathrm{H}_{2} \mathrm{O}_{2}$ versus $\Delta \mathrm{COT}$, efluente $\mathrm{E} 4$, $\mathrm{COT}_{\mathrm{o}}=195$ a $287 \mathrm{mgC} \mathrm{L}^{-1}, \alpha=9,\left[\mathrm{H}_{2} \mathrm{O}_{2}\right]_{0}=53$ a $76 \mathrm{mM}, \mathrm{T}=30$ e $50^{\circ} \mathrm{C}$. Experimentos: BE4-1, BE4-5, BE4-12 e BE4-15. 99

Figura 57 - Configuração possível para o reúso da água.................................... 100

Figura 58 - Rede neural utilizada na modelagem e variáveis de entrada e saída. .103 Figura 59 - Raiz quadrada do erro quadrático médio, para o LS (RMSTL) e o TS (RMSTT), em função do número de apresentações ( $\mathrm{NH}=6$, nํำ de apresentações = 20000 e LS/TS= 3).

Figura 60 - Resíduo médio por ponto experimental em função do número de neurônios, para o modelo M-1 ( $\mathrm{NH}=4$ a 13, no de apresentações = 10000 e LS/TS= 3). 105

Figura 61 - Coeficientes de determinação (R2) e angular (coef. Angular) em função do número de neurônios, para o modelo $\mathrm{M}-1(\mathrm{NH}=4$ a 13, ํㅡ de apresentações = 10000 e LS/TS= 3). Dados do LS.

Figura 62 - Comparação entre COT experimental e calculado para $\mathrm{NI}=10000$ e $\mathrm{NH}=6$, (a) mostra todos os valores da variável de saída COT e (b) leva em

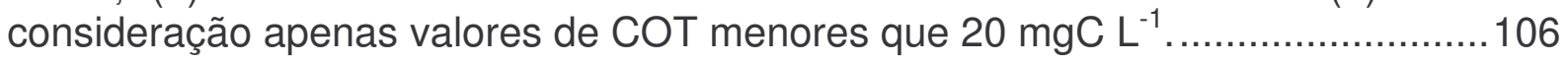

Figura 63 - Resultados para M-2 (efluentes com baixa concentração de COT), $\mathrm{NI}=10000$ e $\mathrm{NH}=5$ : (a) comparação entre valores de COT experimental e calculado; (b) distribuição da função distância para o conjunto de treinamento (LS) e (c) conjunto de teste (TS). A função distância é a diferença entre COT calculado e experimental.

Figura 64 - Resultados para M-3 (efluente com alta concentração de COT), $\mathrm{NI}=10000$ e $\mathrm{NH}=7$ : (a) comparação entre valores de COT experimental e calculado; (b) distribuição da função distância para o conjunto de treinamento (LS) e (c) conjunto de teste (TS). A função distância é a diferença entre COT calculado e experimental. 
Figura 65 - llustração do modelo usado para o cálculo da taxa de remoção de COT. 109

Figura 66 - Comparação dos resultados experimentais (-) e calculados (-) pelo modelo M-1 (alta e baixo teor de matéria orgânica). Experimentos fazem parte da base de dados da RNA para o referido modelo.

Figura 67 - Comparação dos resultados experimentais (-) e calculados (-) pelo modelo $\mathrm{M}$-1a (alta e baixo teor de matéria orgânica). Experimentos não estão na base de dados RNA para o referido modelo.

Figura 68 - Comparação dos resultados experimentais (-) e calculados (-) pelo modelo M-2 (baixo teor de matéria orgânica). O experimento BE1-15 é o único que faz parte da base de dados da RNA para o referido modelo; os demais são experimentos independentes.

Figura 69 - Simulação da superfície de resposta para taxas médias de remoção de COT (durante os primeiros 10 minutos) como função da concentração de $\mathrm{H}_{2} \mathrm{O}_{2}$ e da potência da fonte de luz. COTo $=15 \mathrm{mgC} \mathrm{L}^{-1}$ e $\mathrm{T}=30^{\circ} \mathrm{C}$.

Figura 70 - Curva $E(t) \times t$ para reator contínuo em condições variadas de vazão conforme apresentadas na Tabela 27.

Figura 71 - Curva $E(\Theta)$ para os reatores RFCMS e RFCMI em condições variadas de vazão conforme apresentadas na Tabela 27.Reator de mistura perfeita (---) e reator de fluxo pistonado ideal (-).

Figura 72 - Desvio padrão das distribuições versus vazão de escoamento. 118

Figura 73 - Curva $\mathrm{E}(\mathrm{t})$ versus $\mathrm{t}$ do ensaio 4 e repetição 4'. 120

Figura 74 - Ajustes de modelos aos dados experimentais 122

Figura 75 - Esquema dos fluxos de entradas e saídas no reator contínuo tipo RCFMI. 123

Figura 76 - COT em função de $\theta$ para os ensaios contínuos, do plano experimental. 125

Figura 77 - Representação do Plano de experimentos Doehlert. 125

Figura 78 - Superfície de resposta para o plano experimental Doehlert. 126

Figura 79 - Diagrama de Pareto dos efeitos padronizados 127

Figura 80 - Análise do erro experimental no ponto central. Condições experimentais: ver Tabela 34. 


\section{LISTA DE SÍMBOLOS E SIGLAS}

$\left[\mathrm{H}_{2} \mathrm{O}_{2}\right]_{0}$

A

ABS (665)

ANA

$\mathrm{C}_{\mathrm{H}_{2} \mathrm{O}_{2}}$

$\mathrm{C}(\mathrm{t})$

$\mathrm{C}_{3} \mathrm{H}_{6}$

CAD

CESQ-LSCP

$\mathrm{C}_{\mathrm{OH}}$

$\mathrm{C}_{\mathrm{R} 1}$

COT

$\cot (\mathrm{t})$

$\mathrm{COT}_{\text {calculado }}$

$\mathrm{COT}_{\text {experimental }}$

$\mathrm{COT}_{\text {。 }}$

DBO

DEQ-EPUSP

DQO

DTR

$E(t)$

$\mathrm{E} 1$

E2

E3

E4

$E_{a}$

ETE

Einstein
Concentração de peróxido de hidrogênio, variável de entrada da rede $(\mathrm{mM})$.

constante pré-exponencial

Absorbância em 665nm

Agência Nacional de Águas

Concentração de peróxido de hidrogênio $\left(\mathrm{mg} \mathrm{L}^{-1}\right)$

Concentração de traçador na saída do reator no tempo t (mM)

Fórmula molecular do propileno

Custo de produção água desmineralizada $\left(R \$ / \mathrm{m}^{3}\right)$

Centro de Engenharia de Sistemas Químicos - Laboratório de Simulação e Controle de Processos

Concentração de ${ }^{\circ} \mathrm{OH}(\mathrm{M})$

Concentração de R1 (M)

Carbono orgânico total

COT da solução no tempo t após o início da reação $\left(\mathrm{mgC} \mathrm{L}^{-1}\right)$

COT calculado com os pesos do $\mathrm{LS}\left(\mathrm{mgC} \mathrm{L}^{-1}\right)$

COT experimental $\left(\mathrm{mgC} \mathrm{L}^{-1}\right)$

COT da solução antes da adição de peróxido de hidrogênio $\left(\mathrm{mgC} \mathrm{L}^{-1}\right)$

Demanda biológica de oxigênio $\left(\mathrm{mgO}_{2} \mathrm{~L}^{-1}\right)$

Departamento de Engenharia Química da Escola Politécnica da USP

Demanda química de oxigênio $\left(\mathrm{mgO}_{2} \mathrm{~L}^{-1}\right)$

Distribuição de tempos de residência

Função distribuição de tempo de residência

Corrente efluente do processo P1

Corrente efluente do processo P2

Corrente efluente do processo P3

Corrente efluente do processo P4

Energia de Ativação $(\mathrm{J} / \mathrm{mol})$

Estação de tratamento de efluentes

1 mol de fótons 


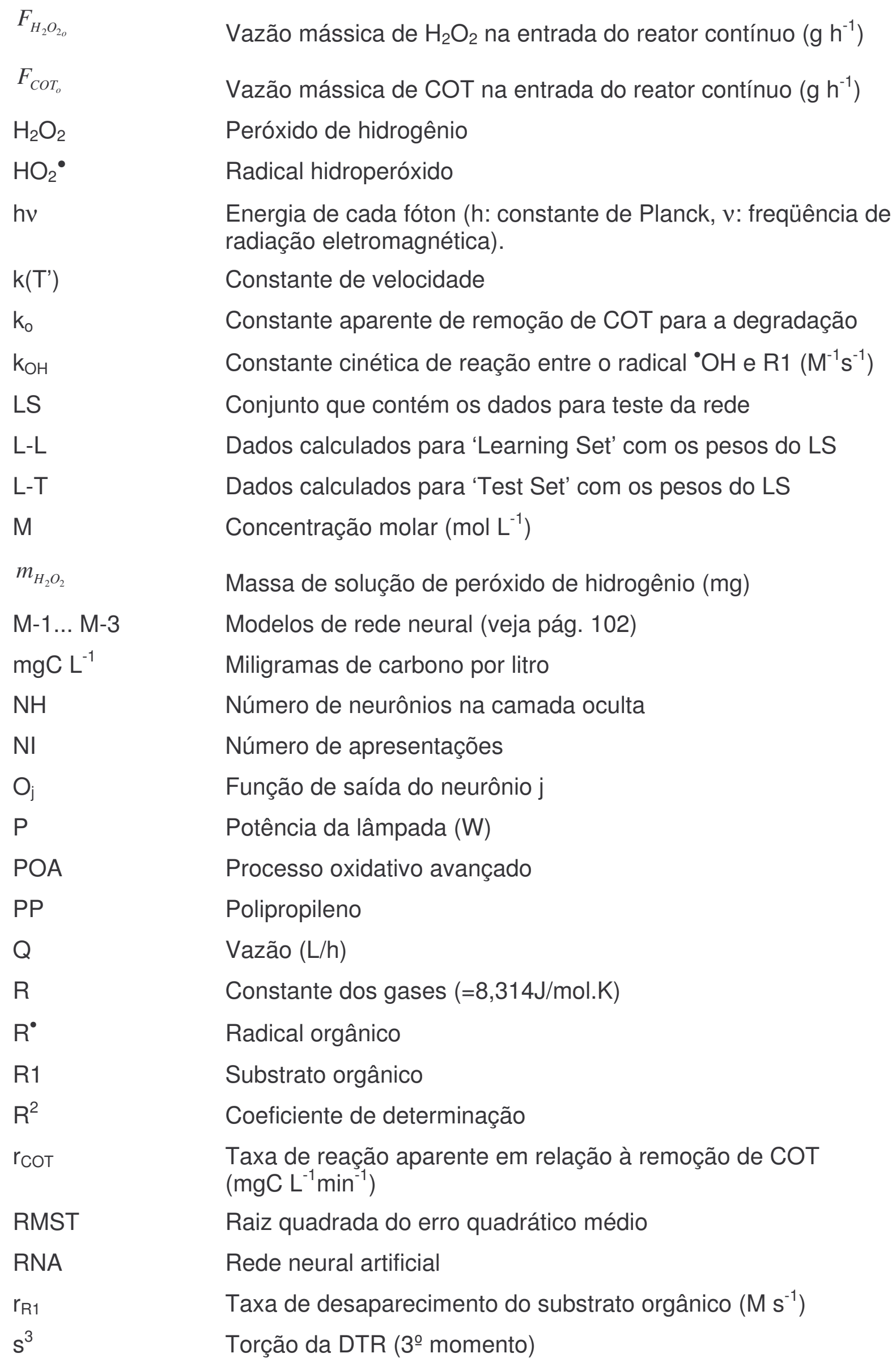




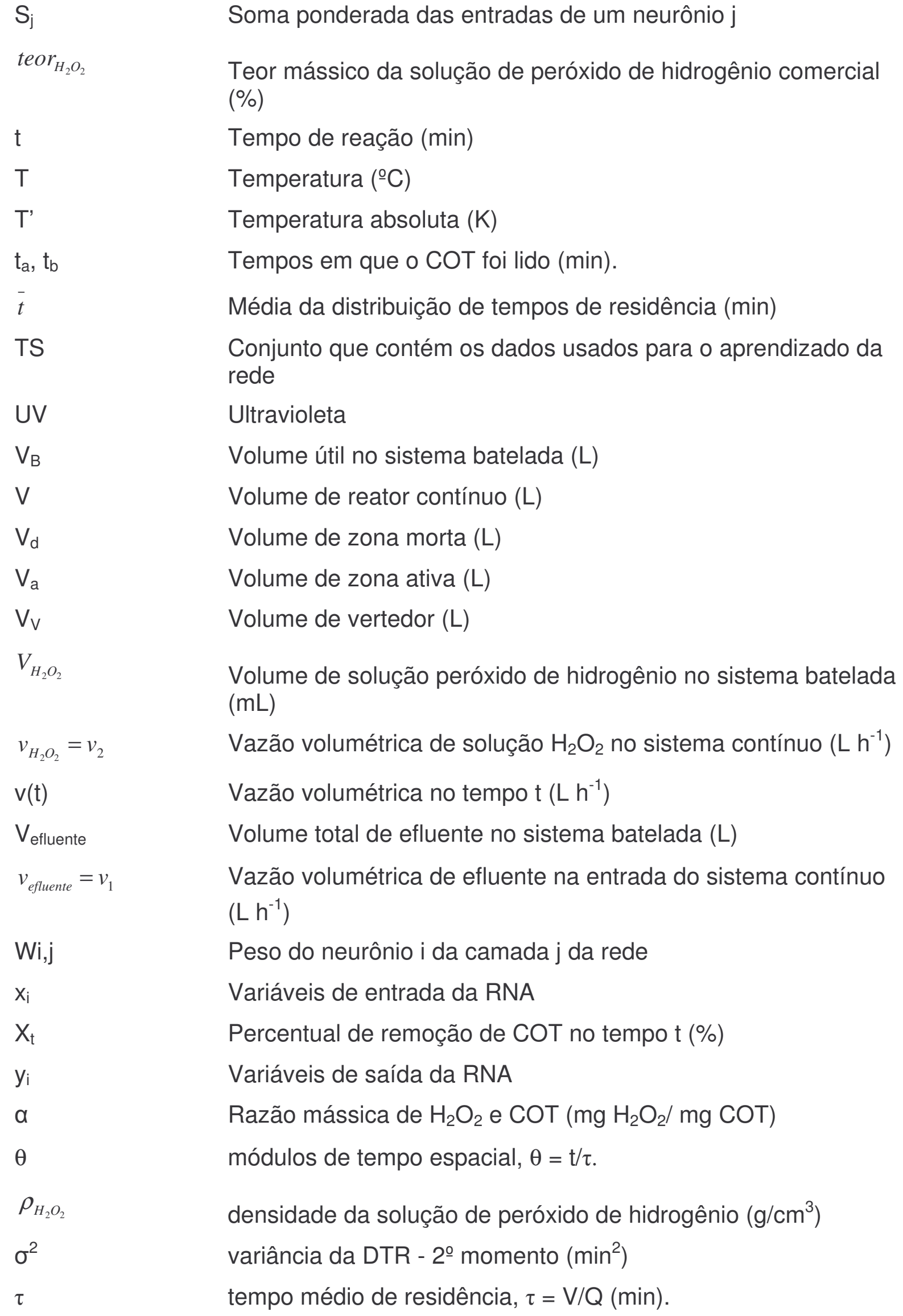




\section{SUMÁRIO}

1. INTRODUÇÃO

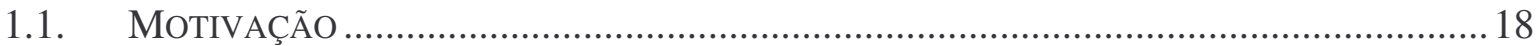

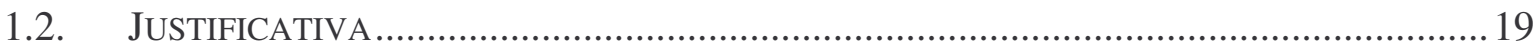

1.3. APRESENTAÇÃO DA EMPRESA.......................................................................... 20

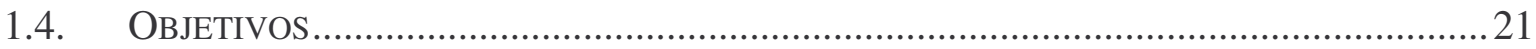

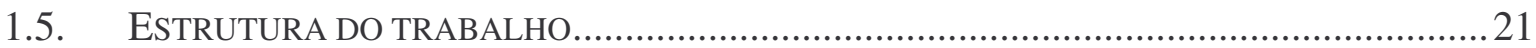

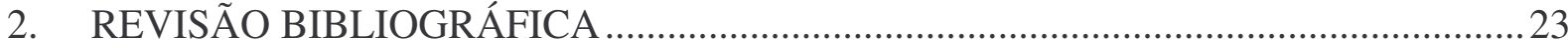

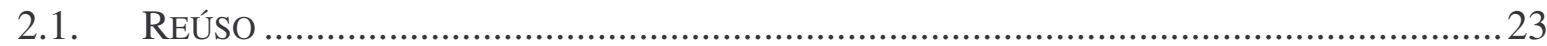

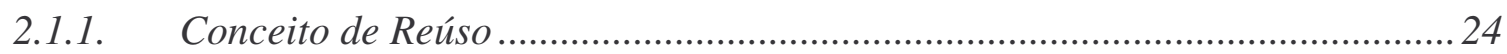

2.1.2. Aspectos Legais da Conservação e Reúso de Água ...........................................2

2.1.3. Tecnologias de Tratamento de Água …………………………………….....2

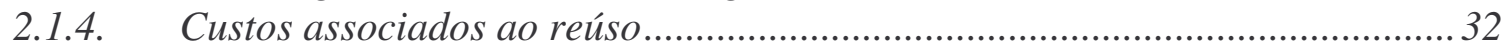

2.1.5. Processos Oxidativos Avançados ...................................................................... 33

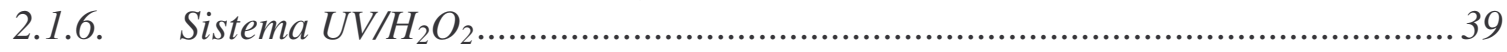

2.1.7. Estudos sobre a degradação foto-oxidativa de Polipropileno ............................51

2.2. PROCESSO CONTÍNUO DE FOTODEGRADAÇÃO …………………………................53

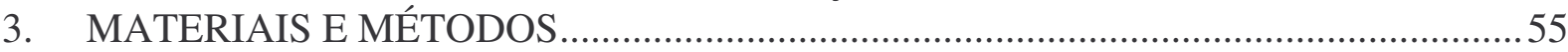

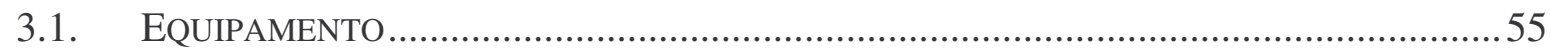

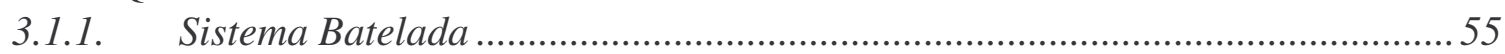

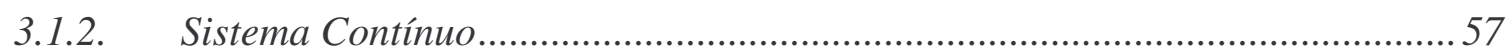

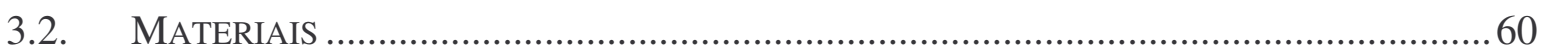

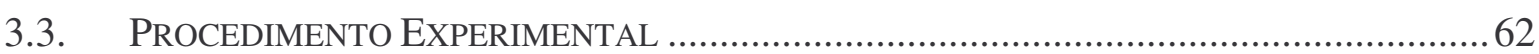

3.3.1. Ensaios de fotodegradação em sistemas descontínuo e contínuo ........................62

3.3.2. Ensaios de Distribuição de tempos de residência (DTR)...................................64 64

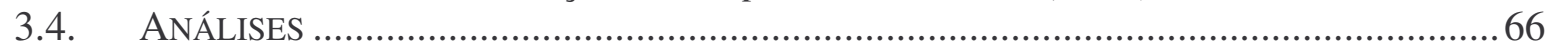

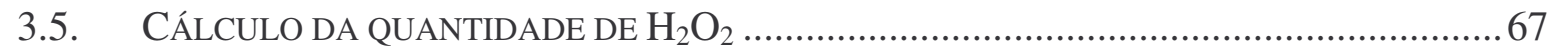

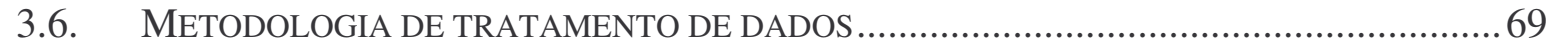

3.6.1. Rede Neural Artificial (RNA) ..................................................................... 69

3.6.2. Distribuição do tempo de residência $(D T R)$.................................................. 71

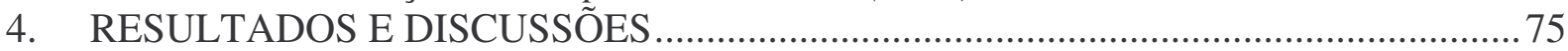

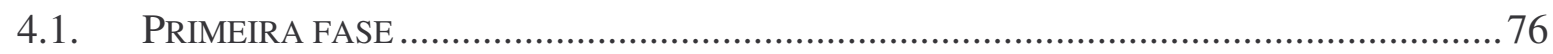

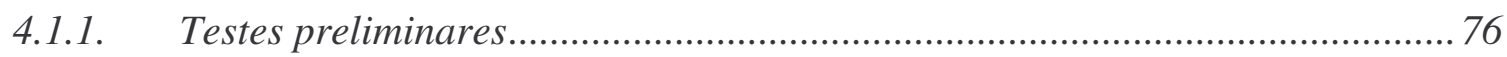

4.1.2. Testes sistemáticos................................................................................... 80

4.1.2.1. Efeito da potência da lâmpada.................................................................... 83

4.1.2.2. Efeito da concentração de peróxido de hidrogênio ......................................87

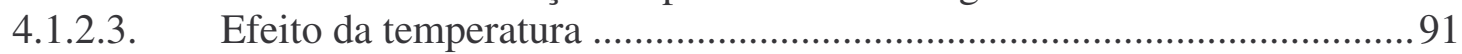

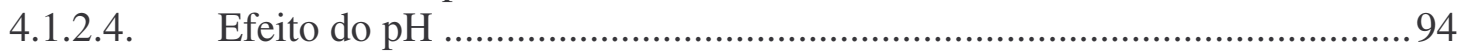

4.1.2.5. Cálculo da constante aparente de remoção de COT ...................................95

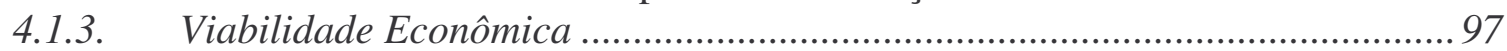

4.1.4. Modelagem por Redes Neurais ................................................................... 102

4.1.4.1. Variáveis de entrada e saída para o modelo de redes neurais...................102

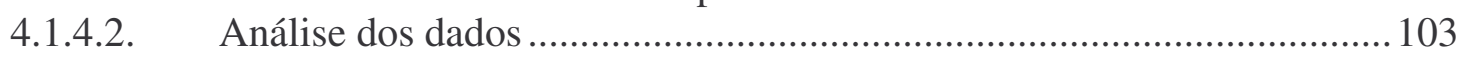

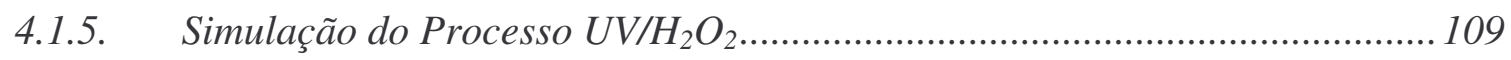

4.1.5.1. Discussão dos resultados de simulação .................................................. 110

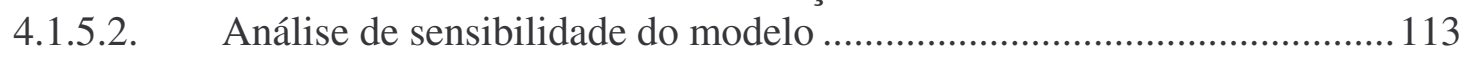

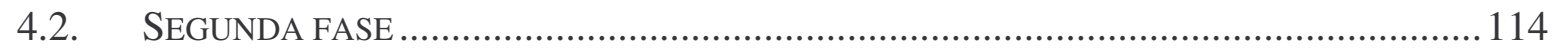

4.2.1. Distribuição de tempos de residência ......................................................... 114

4.2.2. Ensaios fotoquímicos nos Reatores Contínuos................................................ 123 
5. CONCLUSÕES

6. REFERÊNCIAS BIBLIOGRÁFICAS

APÊNDICE A - Código do programa de simulação da Curva de COT x tempo a partir dos pesos obtidos por rede neural:

APÊNDICE B - Cálculo de modelos de distribuição de tempos de residência .......145

APÊNDICE C - Estudo de Viabilidade Econômica

APÊNDICE D - Resultados Gerais dos Ensaios de DTR 150

APÊNDICE E - Resultados dos ensaios fotoquímicos contínuos 156 


\section{INTRODUÇÃO}

\subsection{Motivação}

A água é o insumo básico em muitos processos industriais. O Brasil é um país privilegiado, pois em seu território encontram-se as mais extensas bacias hidrográficas do planeta. No entanto, muitas delas estão distantes dos principais centros populacionais e industriais do país. Segundo Mancuso e Santos (2003), dos $8 \%$ da reserva mundial de águas doces do país, $80 \%$ encontram-se na Região Amazônica, e os restantes 20\% concentram-se nas regiões onde vivem $95 \%$ da população brasileira.

Muitos dos mananciais utilizados estão cada vez mais poluídos devido à falta de controle, insuficiência de investimentos em coleta, tratamento e disposição final adequada de esgotos e de resíduos sólidos. Em conseqüência, a adoção de tarifas escalonadas vem, gradualmente, tornando proibitivo o uso de água potável para processos industriais.

Uma alternativa para a atividade industrial é a utilização de água de reúso. O reúso de água passou a ser mais utilizado na década de 80 quando as águas de abastecimento foram se tornando cada vez mais caras, onerando o produto final quando usado no processo de fabricação. Como o preço de produto, ao lado de sua qualidade, é fator determinante para o sucesso de uma empresa, a indústria passou a procurar, dentro de suas próprias instalações, a solução para o problema, tentando reaproveitar ao máximo seus próprios efluentes. Uma gama de processos foi desenvolvida tais como os processos oxidativos avançados, POAs (LIRA et al., 2005a, 2006a; TELÊMACO et al., 2005).

Os POAs consistem na produção de intermediários altamente reativos, principalmente o radical hidroxila ( $(\mathrm{OH})$ capazes de oxidar a maioria das moléculas orgânicas (ALFANO et al., 2000; ANDREOZZI et al., 1999; GOSLICH; DILLERT; BAHNEMANN, 1997; BIGDA, 1995).

Dentre os vários processos oxidativos classificados como POAs, o processo baseado na combinação da ação da luz ultravioleta e peróxido de hidrogênio $\left(\mathrm{UV} / \mathrm{H}_{2} \mathrm{O}_{2}\right)$ é um dos mais estudados. O sistema UV/ $\mathrm{H}_{2} \mathrm{O}_{2}$ tem se mostrado eficiente na degradação de diversos poluentes presentes em água, tais como: benzeno, 
cloroetano, pesticidas e cetonas (CLARKE; KNOWLES, 1982; GLAZE; LAY; KANG, 1987).

\subsection{Justificativa}

A indústria petroquímica estudada, POLIBRASIL, que desde setembro de 2005, passou a ser chamada de Suzano Petroquímica, possui uma unidade de polimerização, na qual quatro diferentes correntes efluentes (E1, E2, E3 e E4; cf. Figura 1) geradas no processo foram selecionadas para o estudo. Estas correntes são contaminadas predominantemente com oligômeros de propileno não convertidos em polímeros durante o processo produtivo e outros reagentes (p. ex, catalisadores). A demanda de água para esta unidade é suprida atualmente pela rede de abastecimento de água potável. Antes de seguir para a unidade de polimerização propriamente dita, a água potável é desmineralizada por resinas de troca iônica. De acordo com dados fornecidos pela empresa, a soma dos custos de captação e de desmineralização da água da rede de abastecimento é de aproximadamente $\mathrm{R} \$ 7,40 / \mathrm{m}^{3}$. Atualmente, todo efluente gerado na indústria em estudo é tratado biologicamente, conforme apresentado na Figura 1a.

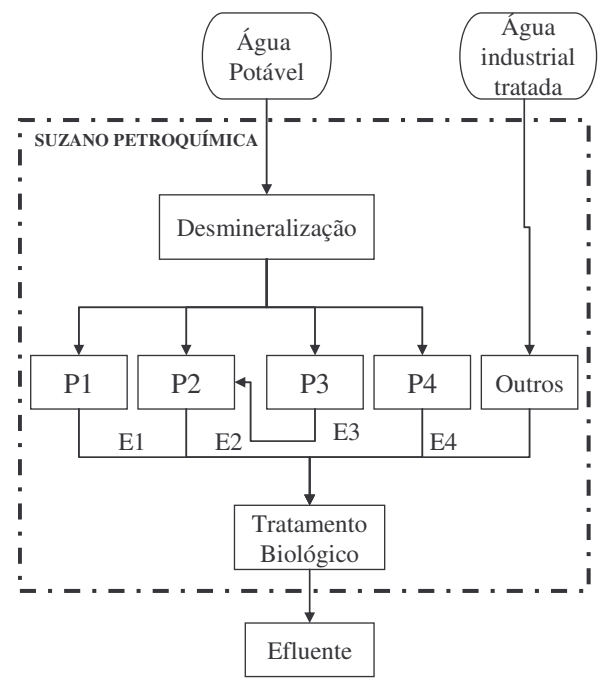

(a)

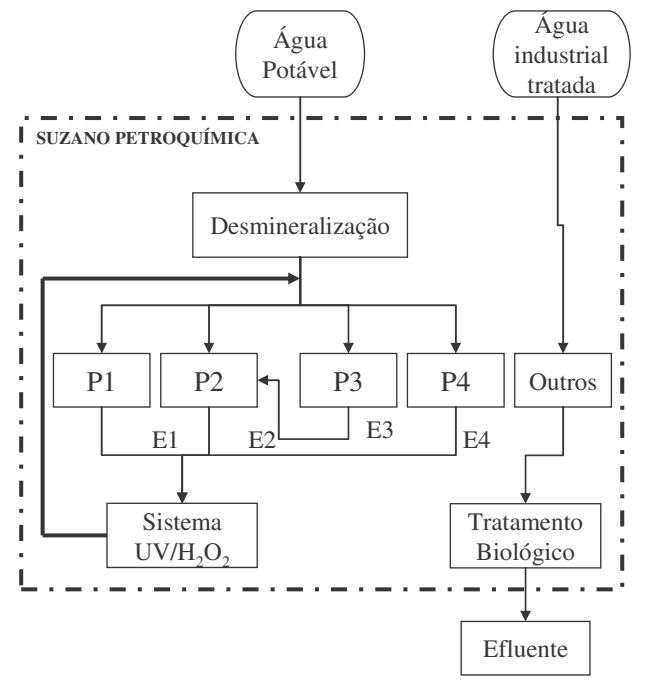

(b)

Figura 1 - Circuito de águas atual (a); Circuito de águas proposto (b). Vazão de geração de efluente: 4 a $5 \mathrm{~m}^{3} / \mathrm{h}$.

$\mathrm{O}$ processo $\mathrm{UV} / \mathrm{H}_{2} \mathrm{O}_{2}$, que se pretende utilizar no lugar do tratamento biológico (Figura 1b), foi selecionado, dentre outros POAs, porque possibilita a 
construção de reatores simples, não necessitando de unidades de separação após o tratamento. O processo requer apenas uma etapa prévia de filtração para a remoção de sólidos suspensos, os quais, se presentes no reator fotoquímico, dispersam a luz, reduzindo assim a eficiência do processo. Uma vez que não há adição de outros compostos químicos além do peróxido de hidrogênio, e que os compostos presentes nas correntes de água de processo são decompostos no processo de tratamento estudado a taxas compatíveis, esses efluentes podem ser realimentados em diferentes pontos de demanda de água nas instalações industriais do complexo petroquímico, sem restrições adicionais.

Os níveis de remoção de contaminantes pelo sistema fotoquímico devem atender as condições operacionais dos processos nos quais a água de reúso será destinada (P1, P2, P3 e P4) com "especificação semelhante da água desmineralizada". Caso estas condições não sejam atendidas, o efluente tratado pelo sistema fotoquímico pode ser encaminhado para alimentação das resinas de troca iônica que produzirá águas desmineralizada. Como as resinas são extremamente sensíveis à presença de ferro solúvel, substâncias oxidantes (entre elas, o cloro) e matéria orgânica na água de alimentação, os níveis satisfatórios de remoção de COT devem ser tais que atendam às especificações do processo industrial. Deve-se também minimizar a concentração residual de peróxido de hidrogênio ao final do tratamento com sistema $U V / \mathrm{H}_{2} \mathrm{O}_{2}$, pois esta substância oxidante pode afetar a eficiência das resinas de troca iônica.

\subsection{Apresentação da empresa}

A Suzano Petroquímica é uma indústria petroquímica que produz e comercializa polipropileno e materiais relacionados, sendo líder no mercado de polipropileno na América Latina. Pelo trabalho de preservação ambiental, realizado com base em padrões internacionais, a Suzano Petroquímica obteve a conquista, no ano 2000, da certificação ISO-14.001 para todas as unidades - Camaçari, Duque de Caxias e Mauá, o que demonstra o seu interesse e comprometimento pelo desenvolvimento econômico vinculado às questões ambientais, tais como o uso racional dos recursos naturais e a proteção do meio ambiente. 
Com base neste comprometimento e por meio de um convênio firmado entre a Universidade de São Paulo, representada pelo Departamento de Engenharia Química da Escola Politécnica, Financiadora de Estudos e Projetos (FINEP), Fundo Setorial de Recursos Hídricos (CTHidro), e Suzano Petroquímica, foi viabilizada a oportunidade para o desenvolvimento de um projeto cujo objetivo é a racionalização do uso da água na indústria. Este trabalho aborda especificamente o tratamento fotoquímico de correntes efluentes de processo para fim de reúso.

\subsection{Objetivos}

O objetivo deste trabalho é estudar, em escala de laboratório, a degradação dos compostos orgânicos presentes nas quatro correntes efluentes empregando radiação ultravioleta e peróxido de hidrogênio, isto é, o sistema $U V / \mathrm{H}_{2} \mathrm{O}_{2}$, visando adequá-las para reúso no próprio processo (Figura 1b). Essa estratégia visa reduzir a captação de água pré-tratada e melhorar o aproveitamento de água, reduzindo assim os custos com a aquisição e despejo de água.

Os objetivos específicos são:

> obter dados sobre a taxa de remoção da matéria orgânica dos efluentes estudados;

> estimar os efeitos das principais variáveis de processo em cada tratamento;

$>\quad$ avaliar o desempenho de um reator contínuo.

\subsection{Estrutura do trabalho}

O capítulo 2 apresenta a revisão bibliográfica sobre os temas relevantes do presente trabalho: reúso de água, processos oxidativos avançados e processos contínuos de fotodegradação.

O capítulo 3, Materiais e Métodos, descreve os equipamentos, materiais utilizados, procedimento experimental adotado, métodos analíticos empregados e ferramentas de tratamento de dados. Este capítulo ilustra que os experimentos de 
degradação de componentes oligoméricos foram realizados em reatores fotoquímicos operando em sistemas batelada e contínuo.

O capítulo 4 apresenta os resultados do estudo, subdivididos em duas fases. Numa primeira fase, experimentos em sistema fotoquímico batelada foram realizados para obtenção de dados experimentais sobre processo de foto-oxidação (sistema $\mathrm{UV} / \mathrm{H}_{2} \mathrm{O}_{2}$ ) de efluente aquoso industrial de origem petroquímica e avaliação técnico-econômica da aplicação do tratamento fotoquímico. Nesta fase os efeitos das principais variáveis foram avaliados e um modelo empírico baseado em redes neurais foi ajustado para simular o processo em função de cinco variáveis (tempo, teor de carbono orgânico inicial, concentrações de peróxido de hidrogênio inicial, potência da lâmpada e temperatura) contidas no intervalo estudado.

$\mathrm{Na}$ segunda fase, experimentos foram conduzidos em reator fotoquímico contínuo projetado com base no reator em sistema batelada, a fim de avaliar o desempenho de processos de foto-oxidação em sistemas contínuos visando à aplicação industrial. O reator contínuo foi submetido a ensaios de distribuição de tempos de residência, com o propósito de analisar as características de escoamento.

O capítulo 5 finaliza o trabalho proposto, por meio da apresentação das principais conclusões que foram obtidas pelo desenvolvimento do mesmo. Este capítulo mostra também sugestões para futuros trabalhos.

Este trabalho foi confeccionado seguindo as Diretrizes para apresentação de dissertações e teses da Escola Politécnica da Universidade de São Paulo. 


\section{REVISÃO BIBLIOGRÁFICA}

\subsection{Reúso}

A água está se tornando um recurso cada vez mais escasso nas regiões metropolitanas devido ao crescimento demográfico, à urbanização, ao desenvolvimento industrial e à expansão do cultivo irrigado. Segundo dados da Agência Nacional de Águas (BRASIL, 2005), ao menos 8\% das reservas mundiais de água doce estão no Brasil, sendo que 80\% encontram-se na Região Amazônica e os $20 \%$ restantes localizam-se nas regiões onde vivem $95 \%$ da população brasileira.

De acordo com a Agência Nacional de Águas, o consumo de água para fins urbanos representa apenas $11 \%$ do volume total de água consumido no Brasil, 0 consumo de água para irrigação pode chegar a 69\%, enquanto que o consumo de água para uso industrial é próximo de 7\% (Figura 2), muito embora esses valores sejam bastante variados, quando se considera cada região isoladamente.

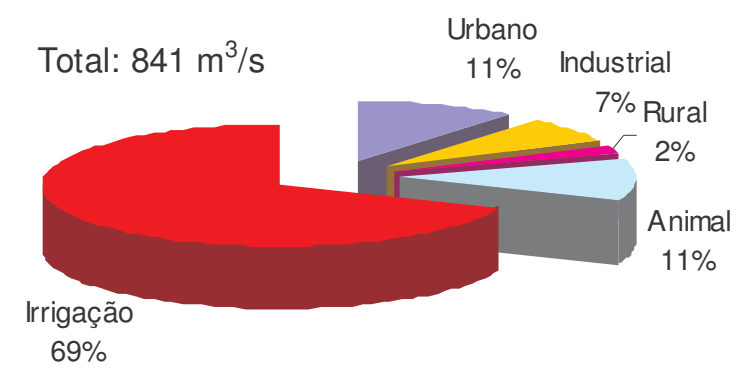

Figura 2 - Vazões de consumo de água para os diferentes usos no Brasil, vazão de consumo Total = $841 \mathrm{~m}^{3} / \mathrm{s}$ (BRASIL, 2005).

O brasileiro tem uma cultura de abundância de água, por isso além do avanço tecnológico, vontade política e mudanças culturais em toda a população são consideradas questões chave para a conservação e reúso de água. Em relação ao tema de conservação da água existem vários níveis que devem ser abordados, entre os quais se destacam: sistema de abastecimento de água, cultivos irrigados, indústrias. No Brasil, as perdas de água tratada no sistema de abastecimento atingem uma média de 30 a 60\% dos volumes produzidos (HERRERA; LEOPOLDO, 1997). Na agricultura, observa-se que o desperdício de água para irrigação de cultivos brasileiros gira em torno de 60\% (COSTA; BARROS JÚNIOR, 2005). Portanto, o potencial para conservação e reúso nesses setores é enorme. 
O outro nível importante em termos de conservação é o industrial. Em geral, as perdas de água ocorrem devido a vazamentos, mau desempenho do sistema, negligência do usuário. Um sistema hidráulico sem manutenção adequada pode perder de 15 a 20\% da água que adentra na unidade (FIESP; CIESP, 2004). Nas indústrias, o desperdício pode ser combatido através de medidas para a otimização do consumo e redução de perdas e desperdícios, além de programas de conscientização e treinamento.

Além da disponibilidade cada vez menor, a água durante a sua utilização acaba tendo as suas características degradadas, ocorrendo contaminação pelos mais distintos tipos de substâncias desenvolvidas e utilizadas pelo homem, o que dá origem aos processos de poluição dos recursos hídricos e contribui para a redução na disponibilidade da água. Atualmente, os problemas mais sérios de poluição referem-se aos efluentes industriais, os quais, devido à grande variedade de atividades desenvolvidas pelas indústrias, podem apresentar em sua composição os mais variados tipos de substâncias, das quais muitas são extremamente tóxicas e podem ter efeitos adversos sobre todos os seres vivos, caso as mesmas atinjam qualquer recurso hídrico (MIERZWA, 2002).

A crescente preocupação com a racionalização dos recursos hídricos aliada aos elevados custos de água industrial no Brasil, particularmente nas regiões metropolitanas, e às exigências da legislação ambiental, têm estimulado as indústrias nacionais a avaliar as possibilidades internas de reúso, principalmente ante as legislações associadas aos instrumentos de outorga e cobrança pela utilização dos recursos hídricos, tanto na tomada de água como nos despejos dos efluentes, que serão efetivamente implantados pela Agência Nacional de Águas em todo o país.

\subsubsection{Conceito de Reúso}

O conceito de reúso de águas não é recente, pois sua aplicação em todo o mundo ocorre há muitos anos, desde a Grécia Antiga que destinava esgotos para irrigação (FELIZATTO, 2001). A reutilização de água pode ser direta ou indireta, decorrente de ações planejadas ou não (Tabela 1). O reúso de água é um dos instrumentos mais importantes para o uso racional da água, o qual abrange também 
o controle de perdas e desperdícios, a minimização da produção de efluentes e do consumo de água. Desse modo, nos últimos anos, o reúso planejado de água tornou-se cada vez mais notório.

Em meio às principais aplicações de reúso estão: a irrigação com efluente industrial tratado, recirculação de águas de processo industrial, coleta de água de chuva, recarga de água subterrânea por reúso de água potável ou não potável (Tabela 2). Especialmente nos casos de efluentes industriais, o reúso da água resulta em benefício ambiental, diminuindo a descarga de poluentes e permitindo alcançar tanto a redução no consumo de água, quanto na quantidade de efluente gerado (NEWTON; SOLT, 1994).

Tabela 1 - Classificação das modalidades de reúso e suas respectivas ocorrências (adaptado de Costa e Barros Júnior, 2005).

\begin{tabular}{ll}
\hline Classificação & Ocorrência \\
\hline Reúso indireto \\
não planejado da \\
água & $\begin{array}{l}\text { ocorre quando a água, utilizada em alguma atividade humana, é descarregada no } \\
\text { meio ambiente e novamente utilizada a jusante, em sua forma diluída, de maneira } \\
\text { não intencional e não controlada. Indo até o ponto de captação para o novo } \\
\text { usuário, a mesma está sujeita às ações naturais do ciclo hidrológico (diluição, } \\
\text { autodepuração). }\end{array}$ \\
\hline $\begin{array}{ll}\text { Reúso indireto } \\
\text { planejado da }\end{array}$ & $\begin{array}{l}\text { ocorre quando os efluentes, depois de tratados, são descarregados de forma } \\
\text { planejada nos corpos de águas superficiais ou subterrâneas, para serem utilizadas } \\
\text { à jusante, de maneira controlada, no atendimento de algum uso benéfico. O reúso } \\
\text { indireto planejado da água pressupõe que exista também um controle sobre as } \\
\text { eventuais novas descargas de efluentes no caminho, garantindo assim que o } \\
\text { efluente tratado estará sujeito apenas a misturas com outros efluentes que } \\
\text { também atendam ao requisito de qualidade do reúso objetivado. }\end{array}$ \\
\hline $\begin{array}{l}\text { Reúso direto } \\
\text { planejado das }\end{array}$ & $\begin{array}{l}\text { ocorre quando os efluentes, depois de tratados, são encaminhados diretamente } \\
\text { de seu ponto de descarga até o local do reúso, não sendo descarregados no meio } \\
\text { ambuas } \\
\text { ambiente. É o caso com maior ocorrência, destinando-se a uso em indústria ou } \\
\text { irrigação. }\end{array}$ \\
\hline
\end{tabular}

Tabela 2 - Aplicações da Água Reciclada (adaptado de FIESP e CIESP, 2004).

\begin{tabular}{|c|c|}
\hline Aplicações & Requisitos \\
\hline $\begin{array}{l}\text { Consumo humano: água utilizada em } \\
\text { ambientes sanitários, vestiários, cozinhas } \\
\text { e refeitórios, bebedouros, equipamentos } \\
\text { de segurança (por exemplo, lava-olhos) } \\
\text { ou em qualquer atividade doméstica com } \\
\text { contato humano direto. }\end{array}$ & $\begin{array}{l}\text { Água potável, atendendo às características estabelecidas } \\
\text { pela Portaria no } 518 \text { - Norma de qualidade da água para } \\
\text { consumo humano, de } 25 / 03 / 2004 \text {, do Ministério da Saúde } \\
\text { (www.saude.gov.br). }\end{array}$ \\
\hline $\begin{array}{l}\text { Matéria Prima: água incorporada ao } \\
\text { produto final (por exemplo, indústrias de } \\
\text { fármacos, de alimentos, de produtos de } \\
\text { higiene pessoal e limpeza doméstica) ou } \\
\text { água utilizada para a obtenção de outros } \\
\text { produtos (por exemplo, o hidrogênio por } \\
\text { meio da eletrólise da áqua). }\end{array}$ & $\begin{array}{l}\text { O grau de qualidade da água pode variar } \\
\text { significativamente, podendo-se admitir a utilização de uma } \\
\text { água com característica equivalente ou superior à da água } \\
\text { utilizada para consumo humano, tendo-se como principal } \\
\text { objetivo a proteção da saúde dos consumidores finais e/ou } \\
\text { a garantia da qualidade final do produto. }\end{array}$ \\
\hline
\end{tabular}


continuação

\begin{tabular}{l}
\hline Aplicações \\
\hline Fluido auxiliar: a água, como fluido \\
auxiliar, pode ser utilizada em diversas \\
atividades, destacando-se a preparação \\
de suspensões e soluções químicas, \\
compostos intermediários, reagentes \\
químicos, veículo, ou ainda, para as \\
operações de lavagem.
\end{tabular}

Geração de energia: água pode ser utilizada por meio da transformação da energia cinética, potencial ou térmica em energia mecânica e posteriormente em energia elétrica.

\section{Requisitos}

O grau de qualidade da água irá depender do processo à que esta se destina. Caso essa água entre em contato com o produto final, o grau de qualidade será mais ou menos restritivo, em função do tipo de produto que se deseja obter. Não havendo contato da água com o produto final, esta poderá apresentar um grau de qualidade menos restritivo que o da água para consumo humano, principalmente com relação à concentração residual de agentes desinfetantes.

No aproveitamento da energia potencial ou cinética, a água é utilizada no seu estado natural, captada de um rio, lago ou outro reservatório; materiais sólidos de dimensões maiores, presente na água, podem danificar os dispositivos de geração de energia. No aproveitamento da energia térmica, após aquecimento e vaporização da água por meio do fornecimento de energia térmica, a mesma deve apresentar um elevado grau de qualidade, para que não ocorram problemas nos equipamentos de geração de vapor ou no dispositivo de conversão de energia.

Fluido de aquecimento e/ou resfriamento Para água na forma de vapor, o grau de qualidade deve ser bastante elevado; água como fluido de resfriamento requer um grau de qualidade bem menos restritivo, devendo-se levar em consideração a proteção e a vida útil dos equipamentos com os quais esta água irá entrar em contato.

Usos diversos:

Aproveitamento de água de chuva Para uso humano, inclusive para como água potável, deve sofrer filtração e cloração; para fins menos nobres, como irrigação de jardins ou lavagem de áreas externas, não necessita de tratamento avançado.

\begin{tabular}{l}
\hline Combate a incêndio \\
\hline Descarga de vasos sanitários \\
\hline Irrigação de áreas verdes \\
\hline Limpeza de instalações \\
\hline Recarga de aqüíferos \\
\hline Sistema de ar condicionado \\
\hline
\end{tabular}

\subsubsection{Aspectos Legais da Conservação e Reúso de Água}

Dentre as leis que incentivam a prática do reúso, a lei nำ 9.433 de 8 de janeiro de 1997 define a água como "um bem de domínio público" e "um recurso natural limitado, dotado de valor econômico". Apesar do tema reúso não estar explicitamente mencionado na lei supracitada, a filosofia do reúso de águas está implicitamente presente em vários aspectos da lei. Esta lei instituiu a Política Nacional de Recursos Hídricos e estabeleceu o Sistema Nacional de Gerenciamento de Recursos Hídricos. Por essa lei, um dos objetivos da Política Nacional de 
Recursos Hídricos é "assegurar à atual e às futuras gerações a necessária disponibilidade de água, em padrões de qualidade adequados aos respectivos usos", acenando para necessidade de racionalização do uso de água. A presente norma legal ainda prevê "a outorga dos direitos de uso de recursos hídricos" e "a cobrança pelo uso de recursos hídricos", cujos valores arrecadados destinam-se prioritariamente à bacia hidrográfica em que foram gerados.

O Art. 19 da Lei no 9433/97, estabelece que a água é um bem econômico sujeito à cobrança, e que os recursos financeiros arrecadados deverão ser utilizados em financiamentos de programas e intervenções na bacia hidrográfica. O Art. 21 da Lei no 9433/97 determinou que a fixação de valores a serem cobrados leve em conta captações, consumo e lançamento de efluentes líquidos ou gasosos. O Art. 22 da Lei no 9433/97 estabelece que os valores arrecadados com a cobrança devam ser aplicados prioritariamente na bacia hidrográfica onde foram gerados, para 0 financiamento de estudos, programas, obras e custeio administrativo das entidades do sistema.

O regime de outorga de direito de uso de recursos hídricos tem como objetivos assegurar o controle quantitativo e qualitativo dos usos de água, por parte do órgão gestor, e o efetivo exercício dos direitos de acesso à água fornecido ao usuário outorgado. O reúso, em si, não é objeto de outorga, pois não intervém diretamente em um corpo d'água. Todavia quando o empreendimento implanta-o, seu balanço hídrico pode ser alterado de forma quantitativa e qualitativa.

A Lei no 9.984, de 17 de julho de 2000, que criou a Agência Nacional de Águas (ANA), entidade federal responsável pela implementação da política e coordenação do Sistema Nacional de Gerenciamento de Recursos Hídricos. Em articulação com os Comitês de Bacia Hidrográfica, à ANA compete a cobrança pelo uso dos recursos hídricos de domínio da União.

A cobrança pelo uso dos recursos hídricos começou na bacia hidrográfica do rio Paraíba do Sul, que banha São Paulo, Rio de Janeiro e Minas Gerais. A cobrança foi implantada nos termos das Deliberações CEIVAP № 008/01, de 6 de dezembro de 2001 e № 015/02, de 4 de novembro de 2002, e foi efetivamente iniciada em 30 de março de 2003, data de vencimento da primeira fatura emitida pela Agência Nacional de Águas. O Comitê para Integração da Bacia Hidrográfica do Rio Paraíba do Sul - CEIVAP definiu a metodologia e a fórmula de cobrança, que diferencia os tipos de uso: captação $\left(R \$ 0,008 / \mathrm{m}^{3}\right)$; consumo - volume captado que 
não retorna ao corpo hídrico (de zero a $\mathrm{R} \$ 0,02 / \mathrm{m}^{3}$ ) e despejo de efluente no corpo receptor (de zero a $\mathrm{R} \$ 0,02 / \mathrm{m}^{3}$ ).

A cobrança pelo uso da água nas Bacias PCJ (Bacias Hidrográficas dos rios Piracicaba, Capivari e Jundiaí) teve início em janeiro de 2006. Os usos de recursos hídricos em rios de domínio dos Estados de São Paulo e Minas Gerais estão sujeitos ao que estabelecem as leis estaduais: em SP a Lei $n$ ำ12.183, de 29/12/05; e em MG no Decreto no 44.046, de 13/06/05. A cobrança aplica-se à captação, ao consumo e ao lançamento dos recursos hídricos utilizados, de acordo com os usos declarados e consolidados e com os mecanismos previstos na Deliberação Conjunta dos Comitês PCJ $n^{0}$ 027/05, de 30/11/05. A formulação para o cálculo dos valores para a cobrança pelo uso dos recursos hídricos leva em consideração os seguintes valores dos "Preços Unitários Básicos - PUB": captação $\left(\mathrm{R} \$ 0,01 / \mathrm{m}^{3}\right)$, consumo $\left(\mathrm{R} \$ 0,02 / \mathrm{m}^{3}\right)$, lançamento de teor de matéria orgânica $(\mathrm{R} \$ 0,10 / \mathrm{kg})$. Estes valores, no entanto, obedecerão a uma progressividade aprovada pelos Comitês PCJ, sendo cobrado 60\% destes valores em 2006, 75\% em 2007 e em 2008 o valor integral.

A cobrança em rios de domínio da União se inicia após a aprovação pelo Conselho Nacional de Recursos Hídricos - CNRH dos mecanismos e valores de cobrança propostos pelos comitês de bacia hidrográfica. Aprovado em dezembro de 2005, o plano permite a tributação, pelos Estados ou municípios, sobre a captação de água em rios e aqüíferos e pelo descarte dos efluentes (quando com qualidade inferior à captada) de indústrias e companhias de saneamento. (FURTADO, 2005).

De acordo com a lei no 9.605 de 12 de fevereiro de 1998, trata-se de crime ambiental o lançamento de resíduos sólidos, líquidos ou gasosos em desacordo com as exigências estabelecidas em leis ou regulamentos. Portanto, torna-se obrigatório o tratamento de efluentes, que representa o passo inicial para reutilização de efluente. De acordo com Leite (2003), o tratamento de água deve ser visto como um meio de purificar a água de qualquer grau de impureza para um grau de pureza que seja adequado ao uso pretendido.

A classificação de corpos d'água e as diretrizes ambientais são estabelecidas pela Resolução CONAMA no 357, de 17 de março de 2005. As águas destinadas ao reúso industrial podem ser provenientes de quaisquer das classes dos corpos d'água definidas pelo capítulo II, seção I, pois estão sujeitas ao uso a que se reservam, desde os menos exigentes (por exemplo: lavagens de pátios) até os mais restritivos, como por exemplo, as águas desmineralizadas ou deionizadas 
resultantes de tratamentos complementares e destinadas a alguns processos industriais específicos.

\subsubsection{Tecnologias de Tratamento de Água}

Uma revisão das práticas de reúso através do mundo mostra que alguns países fizeram progressos significativos no reúso de águas estabelecendo regras e regulamentos e investindo em projetos estratégicos e em tecnologias de tratamento de águas. A Tabela 3 apresenta processos e operações usados em tratamento de águas, sua descrição e respectivas aplicações.

Tabela 3 - Processos e operações unitárias usadas em tratamento de águas

\begin{tabular}{|c|c|c|c|}
\hline \multicolumn{2}{|c|}{ Processo } & Descrição & Aplicação \\
\hline \multirow{2}{*}{ 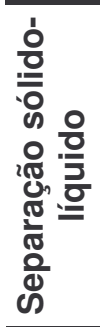 } & Sedimentaçãc & $\begin{array}{l}\text { Sedimentação gravimétrica de } \\
\text { partículas de matéria, flóculos } \\
\text { químicos e precipitados de } \\
\text { suspensão. }\end{array}$ & $\begin{array}{l}\text { Remoção de partículas de águas } \\
\text { túrbidas maiores que } 30 \mu \mathrm{m} \text {. } \\
\text { Remoção de partículas de água maiores } \\
\text { que } 2 \mu \mathrm{m} \text {. }\end{array}$ \\
\hline & Filtração & $\begin{array}{l}\text { Remoção de partículas pela } \\
\text { passagem } \\
\text { de água através de areia ou outros } \\
\text { poros médios. }\end{array}$ & $\begin{array}{l}\text { Freqüentemente usado após a } \\
\text { sedimentação ou coagulação - } \\
\text { floculação. }\end{array}$ \\
\hline \multirow{4}{*}{ 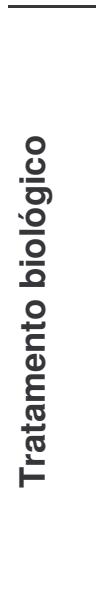 } & $\begin{array}{l}\text { Tratamento } \\
\text { biológico } \\
\text { aeróbio }\end{array}$ & $\begin{array}{l}\text { Oxidação de substâncias orgânicas } \\
\text { por microorganismos em um dique de } \\
\text { aeração ou em um processo de } \\
\text { biofilme. }\end{array}$ & $\begin{array}{l}\text { Remoção de matéria orgânica } \\
\text { dissolvida e suspensa da água } \\
\text { servida. }\end{array}$ \\
\hline & $\begin{array}{l}\text { Tanque de } \\
\text { oxidação }\end{array}$ & $\begin{array}{l}\text { Tanques com } 1,00 \mathrm{~m} \text { de profundidade } \\
\text { para mistura e penetração da luz } \\
\text { solar. }\end{array}$ & $\begin{array}{l}\text { Redução dos sólidos suspensos, } \\
\text { DBO, bactérias patogênicas e amônia } \\
\text { da água servida. }\end{array}$ \\
\hline & $\begin{array}{l}\text { Remoção de } \\
\text { nutrientes }\end{array}$ & $\begin{array}{l}\text { Combinação de processos aeróbios, } \\
\text { anóxidos e anaeróbios para otimizar } \\
\text { a conversão de orgânicos, e remoção } \\
\text { de fósforo e nitrogênio. }\end{array}$ & $\begin{array}{l}\text { Redução do conteúdo de nutrientes } \\
\text { da água exigida. }\end{array}$ \\
\hline & $\begin{array}{l}\text { Tanque de } \\
\text { estabilização } \\
\text { de água } \\
\text { servida }\end{array}$ & $\begin{array}{l}\text { O sistema consiste de tanques } \\
\text { anaeróbio, facultativo e de } \\
\text { maturação ligados em série para } \\
\text { aumentar o tempo de retenção. }\end{array}$ & $\begin{array}{l}\text { Redução dos sólidos suspensos, DBO, } \\
\text { bactérias patogênicas e amônia da água } \\
\text { servida. Instalações para reúso da água } \\
\text { na irrigação e aqüicultura. }\end{array}$ \\
\hline \multicolumn{2}{|c|}{ Desinfecção } & $\begin{array}{l}\text { Inativação de organismos } \\
\text { patogênicos usando oxidação } \\
\text { química, luz ultravioleta, produtos } \\
\text { cáusticos, calor ou processos de } \\
\text { separação física (membranas). }\end{array}$ & Remoção de organismos patogênicos. \\
\hline
\end{tabular}


continuação

\begin{tabular}{|c|c|c|c|}
\hline \multicolumn{2}{|c|}{ Processo } & Descrição & Aplicação \\
\hline \multirow{8}{*}{ 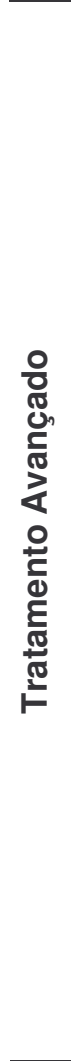 } & $\begin{array}{l}\text { Carvão } \\
\text { ativado }\end{array}$ & $\begin{array}{l}\text { Processo no qual os contaminantes } \\
\text { são fisicamente adsorvidos na } \\
\text { superfície do carvão ativado. }\end{array}$ & $\begin{array}{l}\text { Remoção de compostos orgânicos } \\
\text { hidrofóbicos. }\end{array}$ \\
\hline & $\begin{array}{l}\text { Corrente de } \\
\text { ar }\end{array}$ & $\begin{array}{l}\text { Transferência de amônia e de outros } \\
\text { componentes voláteis da água para o } \\
\text { ar }\end{array}$ & $\begin{array}{l}\text { Remoção de amônia e de alguns } \\
\text { orgânicos voláteis da água. }\end{array}$ \\
\hline & $\begin{array}{l}\text { Permuta de } \\
\text { íons }\end{array}$ & $\begin{array}{l}\text { Permuta de íons entre uma resina e a } \\
\text { água, usando um fluxo através de um } \\
\text { reator. }\end{array}$ & $\begin{array}{l}\text { Remoção efetiva de cátions como } \\
\text { cálcio, magnésio, ferro, amônio e } \\
\text { ânions como nitrato. }\end{array}$ \\
\hline & $\begin{array}{l}\text { Coagulação } \\
\text { química e } \\
\text { precipitação }\end{array}$ & $\begin{array}{l}\text { Uso de sais de alumínio ou de ferro, } \\
\text { polieletrólitos e/ou ozônio para } \\
\text { promover a desestabilização das } \\
\text { partículas coloidais da água e } \\
\text { precipitação de fosfato. }\end{array}$ & $\begin{array}{l}\text { Formação de precipitados de fosfato } \\
\text { e floculação de partículas para remoção } \\
\text { pela sedimentação e filtração. }\end{array}$ \\
\hline & $\begin{array}{l}\text { Tratamento } \\
\text { com cal }\end{array}$ & $\begin{array}{l}\text { O uso de cal para precipitar cátions e } \\
\text { metais da solução. }\end{array}$ & $\begin{array}{l}\text { Usado para reduzir problemas de } \\
\text { incrustação pela precipitação de fosfato } \\
\text { e modificar o pH. }\end{array}$ \\
\hline & $\begin{array}{l}\text { Filtração por } \\
\text { membrana }\end{array}$ & $\begin{array}{l}\text { Microfiltração, nanofiltração e } \\
\text { ultrafiltração. }\end{array}$ & $\begin{array}{l}\text { Remoção de partículas e } \\
\text { microrganismos da água. }\end{array}$ \\
\hline & $\begin{array}{l}\text { Osmose } \\
\text { reversa }\end{array}$ & $\begin{array}{l}\text { Sistema de membranas para separar } \\
\text { íons da solução baseada na pressão } \\
\text { osmótica reversa diferencial. }\end{array}$ & $\begin{array}{l}\text { Remoção de sais e minerais } \\
\text { dissolvidos da solução; também, } \\
\text { remoção efetiva de patogênicos. }\end{array}$ \\
\hline & $\begin{array}{l}\text { Processos } \\
\text { Oxidativos } \\
\text { Avançados }\end{array}$ & $\begin{array}{l}\text { Consistem na produção de } \\
\text { intermediários altamente reativos } \\
\text { capazes de oxidar grande gama de } \\
\text { poluentes. }\end{array}$ & $\begin{array}{l}\text { Oxidação de compostos orgânicos, } \\
\text { inorgânicos dissolvidos e poluentes } \\
\text { tóxicos ou refratários ao tratamento } \\
\text { biológico. }\end{array}$ \\
\hline
\end{tabular}

Fonte: Adaptado de Asano (1998) apud Costa e Barros Júnior (2005).

As tecnologias podem ser utilizadas isoladamente, ou integradas em duas ou mais técnicas, para que melhores resultados sejam alcançados. A seleção das tecnologias dependerá das especificações de aplicação de reúso associado à qualidade de água requerida e do preço que o usuário está disposto a pagar com o tratamento do efluente (MIERZWA; HESPANHOL, 1999; COSTA; BARROS JÚNIOR, 2005).

O uso racional e reúso são ferramentas básicas para os programas de gerenciamento de águas e efluentes na indústria. A adoção da prática do reúso resulta em benefícios não somente ambientais, mas também econômicos e sociais, conforme listados a seguir (FIESP; CIESP, 2004).

BENEFÍCIOS AMBIENTAIS:

$>$ Redução do lançamento de efluentes industriais em cursos d'água, possibilitando melhorar a qualidade das águas;

> Redução da captação de águas superficiais e subterrâneas, possibilitando uma situação mais equilibrada;

$>$ Aumento da disponibilidade de água para usos mais exigentes, como abastecimento público para consumo humano. 


\section{BENEFÍCIOS ECONÔMICOS:}

> Conformidade ambiental em relação a padrões e normas ambientais estabelecidos, possibilitando melhor inserção dos produtos brasileiros nos mercados internacionais;

$>$ Mudanças nos padrões de produção e consumo;

$>$ Redução dos custos de produção;

$>$ Aumento da competitividade do setor;

> Habilitação para receber incentivos e coeficientes redutores dos fatores da cobrança pelo uso da água.

\section{BENEFÍCIOS SOCIAIS:}

$>$ Ampliação da oportunidade de negócios para as empresas fornecedoras de serviços e equipamentos, e em toda a cadeia produtiva;

> Ampliação na geração de empregos diretos e indiretos;

$>$ Melhoria da imagem do setor produtivo junto à sociedade, com reconhecimento de empresas socialmente responsáveis.

No entanto, a prática de reúso de efluentes tratados apresenta limitações técnicas, operacionais e econômicas. Entre as limitações técnicas, pode-se citar: a escolha de um sistema de tratamento adequado capaz de atender os requisitos de qualidade da água para a aplicação na qual se pretende reutilizar o efluente e dificuldade de identificação de oportunidades para a prática de reúso. Como limitações econômicas, apresentam-se: a necessidade de recursos financeiros para aquisição de equipamentos, para implantação e manutenção do sistema de tratamento. As limitações operacionais incluem: necessidade de capacitação de pessoal para operação do sistema e de procedimentos específicos de uso racional da água, como por exemplo: monitoramento e plano de melhoria contínua.

Em certos casos, o reúso só é viável por meio da utilização de técnicas avançadas de tratamento (MIERZWA, 2002). Estas tecnologias incluem troca iônica, membranas (micro, ultra, nanofiltração e osmose reversa), processos físico-químicos (filtração com areia ou carvão ativado e ozonização), processos eletroquímicos (eletrodiálise, eletrodeionização), processos oxidativos avançados (DURHAM; BOURBIGOT; PANKRATZ, 2001; SOUILAH; AKRETCHE; AMARA, 2004; BES-PIÁ et al., 2003; MARCUCCI; TOGNOTTI, 2002; MADWAR E TARAZI, 2002; INTO; JONSSON; LENGDEN, 2004; SONUNE; GHATE, 2004).

Segundo Leite (2003), o reúso de água no Brasil começou nos engenhos de cana-de-açúcar, com a irrigação dos canaviais com o efluente oriundo das destilarias de álcool. A literatura relata diversos exemplos de aplicação de reúso industrial de água (SANTOS, 2004; FURTADO, 2005; BRASIL, 2006) que resultam 
na redução da captação de água, atendimento às exigências da legislação e economia de recursos financeiros.

\subsubsection{Custos associados ao reúso}

De acordo com Butler e Mac Cormick (1996) apud Marcucci e Tognotti (2002), a complexidade das plantas de tratamento para fins de reúso leva ao alto custo de operação. No entanto, muitas vezes o custo é comparável à soma dos custos procedentes da captação e purificação da água para um determinado uso.

Numa avaliação econômica convencional a tomada de decisão sobre a implantação, ou não, de qualquer atividade ou projeto depende, basicamente, do montante de recursos, em geral financeiros, a ser investido e do retorno que se espera obter após a implantação desta mesma atividade ou projeto. Nesta situação, a decisão depende de uma análise comparativa entre os custos e benefícios diretamente relacionados à implantação da atividade ou projeto. Por outro lado, quando as questões ambientais estão envolvidas no processo de tomada de decisão, os conceitos de custo e benefício adquirem uma outra dimensão.

$\mathrm{Na}$ avaliação econômica clássica são considerados apenas os custos e benefícios diretamente associados às atividades em estudo, podendo, em alguns casos, ser considerados os custos e benefícios indiretos. Já em uma avaliação na qual as questões ambientais estão envolvidas, além dos custos mencionados, também devem ser considerados os custos e benefícios intangíveis, os quais são difíceis de avaliar em termos financeiros, muito embora sejam facilmente verificados. Além de gerar uma nova fonte de suprimento de água e limitar as descargas de efluentes, o reúso de água conserva as fontes de águas naturais para necessidades mais nobres, como por exemplo, consumo humano. 


\subsection{Processos Oxidativos Avançados}

Novas tecnologias de tratamento de efluente, incluindo os processos oxidativos avançados (POAs), são desenvolvidas para tratar toxicidade e compostos orgânicos não biodegradáveis.

Os POAs consistem na produção de intermediários altamente reativos, principalmente o radical hidroxila $\left({ }^{\circ} \mathrm{OH}\right)$, capazes de oxidar a maioria das moléculas orgânicas (ALFANO et al., 2000; ANDREOZZI et al., 1999; GOSLICH; DILLERT; BAHNEMANN, 1997). Esses radicais livres reagem de $10^{6}$ a $10^{9}$ vezes mais rapidamente que outros oxidantes químicos fortes, tais como ozônio e peróxido de hidrogênio, utilizados em processos de oxidação química convencional (BIRCHER et al., 1997 apud INCE E TEZCANLI, 1999).

$\mathrm{O}$ radical hidroxila possui potencial redox de $2,8 \mathrm{~V}$ comparado ao eletrodo padrão de hidrogênio (EPH), menor apenas do que o flúor, cujo potencial é de 3,0 V (BELTRÁN; GONZÁLEZ, M.; GONZÁLEZ, J. F., 1997; TEIXEIRA e JARDIM, 2004).

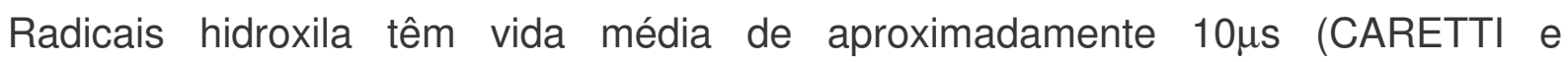
LUBELLO, 2003) e são capazes de reagir muito rapidamente e pouco seletivamente com a maioria dos compostos orgânicos e inorgânicos no meio aquoso (BUXTON et al., 1988), iniciando uma rápida cadeia de reações de oxidação dos contaminantes que são transformados em moléculas menores, podendo ser completamente mineralizados em dióxido de carbono, água e íons inorgânicos (Eq. 1 ).

$\mathrm{POA} \rightarrow{ }^{\bullet} \mathrm{OH}+$ poluentes $\rightarrow \mathrm{CO}_{2}+\mathrm{H}_{2} \mathrm{O}+$ íons inorgânicos

Os radicais hidroxila reagem pouco seletivamente com a maioria dos compostos orgânicos com constante cinética de reação da ordem de $10^{9} \mathrm{M}^{-1} \mathrm{~s}^{-1} \mathrm{a}$ $10^{10} \mathrm{M}^{-1} \mathrm{~s}^{-1}$, de acordo com a reação abaixo (BUXTON et al., 1988 apud BELTRÁN; GONZÁLEZ, M.; GONZÁLEZ, J. F., 1997).

$$
\cdot \mathrm{OH}+\mathrm{R} 1 \rightarrow \mathrm{H}_{2} \mathrm{O}+\mathrm{R}^{\bullet} \quad\left(r_{R I}=-k_{O H} C_{O H} C_{R_{1}}\right)
$$

Em que: $R 1$ = susbtrato orgânico, $R^{*}=$ radical orgânico, $r_{R 1}=$ taxa de desaparecimento do substrato orgânico, $\mathrm{k}_{\mathrm{OH}}=$ constante cinética de reação entre o radical ${ }^{\circ} \mathrm{OH}$ e $\mathrm{R} 1, \mathrm{C}_{\mathrm{OH}}=$ concentação de ${ }^{\circ} \mathrm{OH}$, $\mathrm{C}_{\mathrm{R} 1}=$ concentração de R1.

A Tabela 4 mostra constantes cinéticas de reação de ataque de ${ }^{\circ} \mathrm{OH}$ a alguns substratos específicos, obtidos em estudos prévios, confirmando o que já foi relatado anteriormente por Buxton et al. (1988). 
Tabela 4 - Constantes de reação: ${ }^{\circ} \mathrm{OH}+\mathrm{R} 1 \rightarrow \mathrm{H}_{2} \mathrm{O}+\mathrm{R}^{\bullet}$

\begin{tabular}{|c|c|c|}
\hline Substrato - R1 & $\mathrm{K}_{\mathrm{OH}}\left(\mathrm{M}^{-1} \mathrm{~s}^{-1}\right)$ & Referência \\
\hline DBCP (1,2-dibromo-3-cloropropano) & $1,50.10^{8}$ & Crittenden et al. (1999) \\
\hline Fluoreno & $(9,9 \pm 0,8) \cdot 10^{9}$ & Béltran et al. (1996) \\
\hline Fenantreno & $(13,4 \pm 1,4) \cdot 10^{9}$ & \\
\hline Acenafteno & $(8,8 \pm 0,3) \cdot 10^{9}$ & \\
\hline TCE (tricloroeteno) & $4,2.10^{9}$ & Buxton et al. (1988) apud Bolton et al. (2001) \\
\hline MTBE (metil terc-butil éter) & $(3,9 \pm 0,73) \cdot 10^{9}$ & Chang e Young (2000) \\
\hline TBF (terc-butil formato) & $(1,2 \pm 0,40) \cdot 10^{9}$ & \\
\hline PNP (4-nitrofenol) & $3,8.10^{9}$ & Cercek e Ebert (1968) e Neta e Dorfman \\
\hline NBE (nitrobenzeno) & $3,2.10^{9}$ & (1968) apud Einschlag (2002) \\
\hline $\begin{array}{l}\text { CDNBA (4-cloro-3,5-ácido } \\
\text { dinitrobenzóico) }\end{array}$ & $(3,3 \pm 0,2) \cdot 10^{8}$ & Einschlag; Carlos e Capparelli (2003) \\
\hline CDNB (1-cloro,2-4dinitrobenzeno) & $(8,2 \pm 0,5) \cdot 10^{8}$ & \\
\hline DNB (1,3-dinitrobenzeno) & $(1,1 \pm 0,5) \cdot 10^{9}$ & \\
\hline DNP (2,4-dinitrofenol) & $(2,3 \pm 0,4) \cdot 10^{9}$ & \\
\hline NBE (nitrobenzeno) & $(4,2 \pm 0,4) \cdot 10^{9}$ & \\
\hline MNP (3-nitrofenol) & $(5,0 \pm 0,4) \cdot 10^{9}$ & \\
\hline ONP (2-nitrofenol) & $(5,9 \pm 0,7) \cdot 10^{9}$ & \\
\hline PNP (4-nitrofenol) & $(6,2 \pm 0,6) \cdot 10^{9}$ & \\
\hline PNT (4-nitrotolueno) & $(8,2 \pm 0,5) \cdot 10^{9}$ & \\
\hline MNT (3-nitrotolueno) & $(8,6 \pm 0,5) \cdot 10^{9}$ & \\
\hline $\mathrm{CH}_{3} \mathrm{SO}_{2}^{-}$(sulfonato de metila) & $\begin{array}{l}5,3.10^{9} \\
1.0 .10^{9}\end{array}$ & $\begin{array}{l}\text { Buxton and Greenstock (1998) apud Lee et } \\
\text { al. (2004) }\end{array}$ \\
\hline Formaldeído & & \\
\hline
\end{tabular}
$\mathrm{k}_{\mathrm{OH}}$ : Constante cinética de reação entre ${ }^{\circ} \mathrm{OH}$ e R1 $\left(\mathrm{M}^{-1} \mathrm{~s}^{-1}\right)$

A produção de radicais hidroxila pode ocorrer de diversas formas, através de reações envolvendo oxidantes fortes, como ozônio $\left(\mathrm{O}_{3}\right)$ e peróxido de hidrogênio $\left(\mathrm{H}_{2} \mathrm{O}_{2}\right)$, ou semicondutores, como dióxido de titânio e óxido de zinco. A Tabela 5 apresenta alguns exemplos dos processos de geração de radicais hidroxila, classificados em térmicos, eletroquímicos ou induzidos por luz.

Tabela 5 - Exemplos de processos térmicos e induzidos por luz para a produção de radicais hidroxila (adaptado de Will, 1998 e Teixeira e Jardim, 2004).

\begin{tabular}{ll}
\hline Processos térmicos & Processos induzidos por luz \\
\hline $\mathrm{H}_{2} \mathrm{O}_{2}-\mathrm{Fe}^{2+}$ (Reagente de Fenton) & $\mathrm{UV}$ (fotólise) \\
\hline $\mathrm{O}_{3} / \mathrm{OH}^{-}$ & $\mathrm{H}_{2} \mathrm{O}_{2}-\mathrm{Fe}^{2+} / \mathrm{hv}$ (foto-Fenton) \\
\hline $\mathrm{H}_{2} \mathrm{O}_{2} / \mathrm{O}_{3}$ & $\mathrm{H}_{2} \mathrm{O}_{2} / \mathrm{hv}$ \\
\hline & $\mathrm{O}_{3} / \mathrm{hv}$ \\
\hline Processos eletroquímicos & $\mathrm{H}_{2} \mathrm{O}_{2} / \mathrm{O}_{3} / \mathrm{hv}$ \\
\hline Feixe de elétrons & $\mathrm{TiO}_{2} / \mathrm{O}_{3} / \mathrm{hv}$ \\
\hline Eletro-Fenton & $\mathrm{TiO}_{2} / \mathrm{H}_{2} \mathrm{O}_{2} / \mathrm{hv}$ \\
\hline
\end{tabular}

POAs são alternativas tecnológicas eficientes para destruir substâncias orgânicas de difícil degradação e muitas vezes em baixa concentração (DEZOTTI, 2000). Apresentam-se também como opção aos tratamentos de águas tradicionais que não degradam os poluentes (por exemplo: dessorção "air stripping", adsorção e membranas), pois neste processo os contaminantes são destruídos em oposição à mera transferência de uma fase para outra (CRITTENDEN et al., 1999). 
O uso de técnicas avançadas de tratamento de efluentes, principalmente os processos de separação por membranas, para a viabilização da prática de reúso pode conduzir a resultados satisfatórios em relação ao volume e à qualidade do efluente que poderá ser reutilizado. Por outro lado, essas técnicas podem resultar na geração de um efluente com características que impeçam o seu lançamento para o meio ambiente (MIERZWA, 2002).

$\mathrm{Na}$ literatura, a maioria das aplicações de POA refere-se à oxidação de compostos orgânicos, compostos inorgânicos dissolvidos e outros poluentes que são tóxicos e/ou refratários ao tratamento biológico (BENITEZ et al., 1996; BELTRÁN; GONZÁLEZ, M.; GONZÁLEZ, J. F., 1997; ESPULGAS et al., 2002). POA é uma tecnologia efetiva para tratamento de águas contaminadas e suas aplicações incluem: (1) águas subterrâneas contaminadas, (2) efluentes industriais, (3) esgoto municipal, (4) água potável, (5) chorume e (6) águas superficiais contaminadas (EPA, 1998).

POAs podem ser combinados com carvão ativado, processos biológicos e outros, diminuindo o custo total de tratamento (DEZOTTI, 2000). Entretanto, poucas referências são encontradas sobre a aplicação de POAs para reúso (CARETTI; LUBELLO, 2003; ACERO et al., 2004).

A Tabela 6 apresenta uma compilação da bibliografia sobre os processos oxidativos avançados aplicados para fim de reúso.

Caretti e Lubello (2003) estudaram, em escala piloto, o tratamento combinado por ácido peracético e radiação UV para desinfecção de efluente secundário de uma estação de tratamento de esgoto municipal e industrial, obtendo excelentes resultados de degradação para o reúso na agricultura.

Acero et al. (2004) conduziram experimentos em reatores de mistura completa em batelada de volume de $1 \mathrm{~L}$, cujos resultados indicaram que o ozônio sozinho é capaz de eliminar grande parte da matéria orgânica (entre 81,2 e 99,2\% de remoção de compostos fenólicos) presente nos efluentes de processos de fabricação de cortiça, que contém substâncias tais como ácidos fenólicos, uma fração tânica, 2,4,6-tricloroanisol (TCA) e pentaclorofenol (DQO = $1600 \mathrm{mg} \mathrm{O} / \mathrm{L}$ ). Uma melhora nos resultados foi observada em experimentos nos quais ozônio foi combinado com $\mathrm{H}_{2} \mathrm{O}_{2}$ e/ou UV (remoção de compostos fenólicos entre 95,2 e 100\%). Isso pode ser atribuído à geração adicional de radicais hidroxila devido à presença de $\mathrm{H}_{2} \mathrm{O}_{2}$ ou radiação UV. Entre os POAs, o sistema $U V / \mathrm{H}_{2} \mathrm{O}_{2}$ foi o menos efetivo em 
relação à combinação de $\mathrm{O}_{3} \operatorname{com~} \mathrm{H}_{2} \mathrm{O}_{2}$ e/ou UV (remoção de compostos fenólicos entre 17,3 e $46,2 \%$ ) e a degradação alcançada pelos sistemas Fenton e foto-fenton não foi suficiente para promover o reúso do efluente (remoção de compostos fenólicos entre 30,1 e 56,3\%). Os tratamentos via $\mathrm{O}_{3}, \mathrm{O}_{3} / \mathrm{H}_{2} \mathrm{O}_{2}, \mathrm{O}_{3} / \mathrm{UV}$ e $\mathrm{O}_{3} / \mathrm{H}_{2} \mathrm{O}_{2} / \mathrm{UV}$ tornaram o efluente apropriado para o reúso. 
Tabela 6 - Revisão bibliográfica sobre os processos oxidativos avançados aplicados ao reúso de efluentes

\begin{tabular}{|c|c|c|c|c|c|}
\hline \multirow{2}{*}{$\begin{array}{l}\text { Referência } \\
\text { Caretti e } \\
\text { Lubelo } \\
(2003)\end{array}$} & \multirow[b]{2}{*}{$\begin{array}{l}\text { Aplicação } \\
\text { Desinfecção de efluente } \\
\text { secundário de uma ETE para } \\
\text { reúso indireto na agricultura. } \\
\text { Parâmetro monitorado: } \\
\text { coliformes totais. } \\
\text { Meta: } 2 \text { NMP } / 100 \mathrm{~mL}^{\mathrm{A}}\end{array}$} & \multirow[b]{2}{*}{$\begin{array}{l}\text { Condições Experimentais } \\
\text { Efluente real (Coliformes totais }=307.000 \mathrm{NMP} / 100 \mathrm{~mL}) \\
\text { Tipo de POA: Ácido peracético (PAA)+UV } \\
\text { PAA: } M=2-8 \text { ppm } \\
\text { UV: lâmpadas de baixa pressão } \\
\quad \text { emissão efetiva de UV }=20 \mathrm{~W} \\
\quad \text { dose }=100-300 \mathrm{~mJ} / \mathrm{cm}^{2} \\
\text { Reator piloto anular: vazão }=2-16 \mathrm{~m}^{3} / \mathrm{h} \text {; tempo de contato=3- } \\
\text { 24s; volume }=13,6 \mathrm{~L}\end{array}$} & \multicolumn{3}{|c|}{ Resultados } \\
\hline & & & \multicolumn{3}{|c|}{ inativação total de coliformes totais. } \\
\hline $\begin{array}{l}\text { Acero et al. } \\
(2004)\end{array}$ & $\begin{array}{l}\text { Eliminação de contaminação de } \\
\text { efluentes de processos de } \\
\text { fabricação de cortiça contendo } \\
\text { ácidos fenólicos, 2,4,6- } \\
\text { tricloroanisol (TCA) e o } \\
\text { pentaclorofenol. } \\
\text { Parâmetros monitorados: DQO, } \\
\text { compostos fenólicos (CF) } \\
\text { Meta: não definida }\end{array}$ & $\begin{array}{l}\text { Efluente real (DQO }=1600 \mathrm{mg} / \mathrm{L}, \mathrm{CF}=305 \mathrm{mg} / \mathrm{L}, \mathrm{pH}=4,8) ; \\
\text { Tipos de POA: UV, } \mathrm{UV} / \mathrm{H}_{2} \mathrm{O}_{2} \text {, Fenton, } \mathrm{O}_{3} \text {, Foto-fenton, } \\
\mathrm{O}_{3} / \mathrm{H}_{2} \mathrm{O}_{2}, \mathrm{O}_{3} / \mathrm{UV} \text { e } \mathrm{O}_{3} / \mathrm{H}_{2} \mathrm{O}_{2} / \mathrm{UV} \text {. } \\
\text { UV: radiação policromática entre } 185 \text { a } 436 \mathrm{~nm} ; \\
\quad \text { potência nominal }=150 \mathrm{~W} ; \\
\quad \text { radiação absorvida pelo reator }=1,76.10^{-5} \text { eins } / \mathrm{s} \\
\quad\left[\mathrm{H}_{2} \mathrm{O}_{2}\right]_{0}=0,1 \mathrm{M},\left[\mathrm{Fe} \mathrm{e}^{2+}\right]_{0}=0,001 \mathrm{M}, \mathrm{pO} \mathrm{O}_{3}=4,4 \mathrm{kPa} \text { (pressão } \\
\text { parcial de Ozônio), } \mathrm{T}=40^{\circ} \mathrm{C}, \mathrm{pH}=4.8 \\
\text { Reator batelada anular: vaso de vidro, poço de quartzo, tempo } \\
\text { de reação=3h, volume }=1 \mathrm{~L} \text {. }\end{array}$ & $\begin{array}{l}\mathrm{X}_{\mathrm{DQO}} \text { : remoção de } \mathrm{DC} \\
\mathrm{X}_{\mathrm{CF}} \text { : remoção de com } \\
\text { Processo } \\
\text { UV } \\
\text { UV/ } \mathrm{H}_{2} \mathrm{O}_{2} \\
\text { Fenton } \\
\mathrm{O}_{3} \\
\text { Foto-fenton } \\
\mathrm{O}_{3} / \mathrm{H}_{2} \mathrm{O}_{2} \\
\mathrm{O}_{3} / \mathrm{UV} \\
\mathrm{O}_{3} / \mathrm{H}_{2} \mathrm{O}_{2} / \mathrm{UV}\end{array}$ & $\begin{array}{c} \\
\text { ostos fenóli } \\
\text { X }_{\text {DQO }}(\%) \\
8,8 \\
29,7 \\
58,4 \\
69,3 \\
74,8 \\
79,8 \\
97,9 \\
98,2\end{array}$ & $\begin{array}{l}\text { os } \\
X_{\text {CF }}(\%) \\
10,0 \\
46,2 \\
56,3 \\
93,6 \\
52,2 \\
97,7 \\
99,9 \\
99,4\end{array}$ \\
\hline
\end{tabular}

${ }^{\mathrm{A}}$ NMP: número mais provável; ${ }^{\mathrm{B}}$ plexiglass: poli (metil metacrilato) 
A adequação dos POAs para a degradação de poluentes foi reconhecida a partir do início da década de 1970 e muitas pesquisas e trabalhos têm sido desenvolvidos para a comercialização de alguns desses processos (PARSONS, 2004). POAs têm mostrado grande potencial no tratamento tanto de baixas quanto de altas concentrações de poluentes (Figura 3), motivo pelo qual se encontram diversas aplicações para estes processos, tais como tratamento de águas subterrâneas, de esgoto municipal e controle de compostos orgânicos voláteis (VOCs).

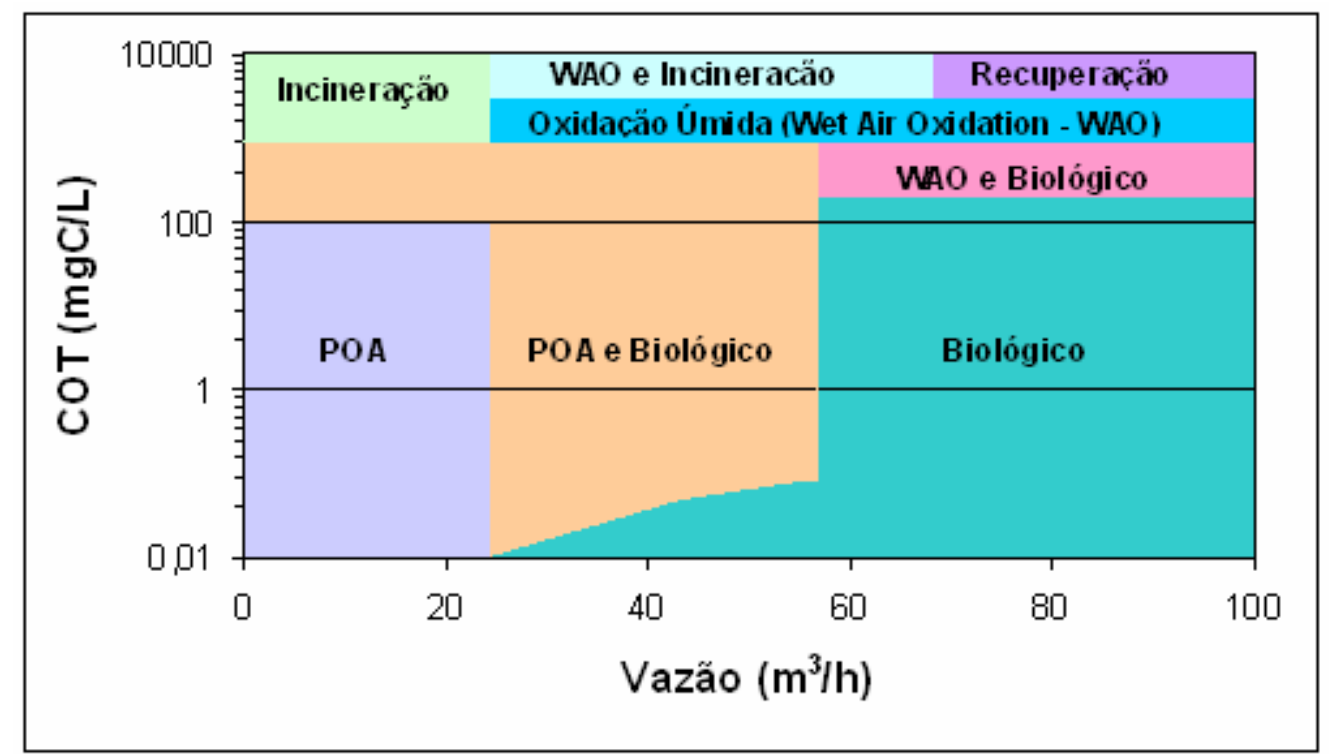

Figura 3 - Mapa tecnológico: tratamentos de efluentes classificados em função do COT (carbono orgânico total) presente em efluentes e vazões volumétricas de efluentes gerados (adaptado de HANCOCK, 1999).

O mapa apresentado na Figura 3 oferece as áreas em que as tecnologias são técnica e economicamente mais efetivas. Os limites, embora traçados, são na verdade difusos e devem ser somente usados como guia. O modelo de custo empregado para obtenção do mapa é baseado em simples hipóteses: em alto COT e altas vazões volumétricas, os tratamentos biológicos provaram ser viáveis; em baixas vazões volumétricas, os POAs são tecnologias promissoras, compatíveis com os valores que são estudados no presente trabalho (cf. item 1.2 Justificativa).

Sanz et al. (2002a) alertam que entre as limitações dos POAs, os aspectos econômicos são determinantes, especialmente devido aos altos custos energéticos (radiação UV, geração de ozônio). 


\subsubsection{Sistema $\mathrm{UV} / \mathrm{H}_{2} \mathrm{O}_{2}$}

O sistema UV/ $\mathrm{H}_{2} \mathrm{O}_{2}$ consiste na combinação de radiação ultravioleta (UV) com peróxido de hidrogênio $\left(\mathrm{H}_{2} \mathrm{O}_{2}\right)$. Este processo é baseado em duas etapas principais: a formação de radicais hidroxila pela fotólise direta de $\mathrm{H}_{2} \mathrm{O}_{2}$ (Eq. 3) e pelas reações de oxidação das moléculas orgânicas pelos radicais de acordo com as equações ( 4 ), ( 5 ) e ( 6 ) (Braun e Oliveros, 1997).

Formação de radical ${ }^{\circ} \mathrm{OH}$ por fotólise direta de $\mathrm{H}_{2} \mathrm{O}_{2}$ :

$\mathrm{H}_{2} \mathrm{O}_{2}+\mathrm{hv} \rightarrow 2^{\circ} \mathrm{OH}$

Abstração de hidrogênio:

$\cdot \mathrm{OH}+\mathrm{RH} \rightarrow \mathrm{H}_{2} \mathrm{O}+\mathrm{R}^{\bullet}$

Adição a ligações insaturadas:

$\cdot \mathrm{OH}+\mathrm{X}_{2} \mathrm{C}=\mathrm{CX}_{2} \rightarrow \mathrm{X}_{2} \mathrm{C}(\mathrm{OH})-\mathrm{C}^{\cdot} \mathrm{X}_{2}$

Transferência de elétrons:

$\cdot \mathrm{OH}+\mathrm{RX} \rightarrow{ }^{-} \mathrm{OH}+\mathrm{XR}^{+} \cdot$

Peróxido de hidrogênio pode reagir diretamente com compostos orgânicos. Entretanto, a combinação do $\mathrm{H}_{2} \mathrm{O}_{2}$ com UV (Eq. 3) gera radical hidroxila, um forte oxidante, conforme discutido anteriormente.

Os radicais orgânicos gerados pelas equações 4 a 6 originam uma série de reações de oxidação essenciais à aceleração da degradação de substratos orgânicos, podendo até levar a sua completa mineralização (formação de $\mathrm{CO}_{2}, \mathrm{H}_{2} \mathrm{O}$ e íons inorgânicos).

Outros possíveis mecanismos de reação com ${ }^{\circ} \mathrm{OH}$ podem ocorrer conforme mostrado nas equações de ( 7 ) a ( 10 ) (CHANG; YOUNG, 2000; CRITTENDEN et al., 1999):

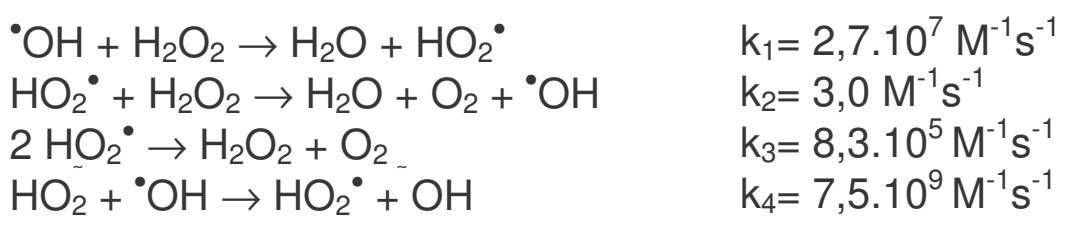

$\mathrm{O}$ radical hidroperóxido $\left(\mathrm{HO}_{2}{ }^{\circ}\right)$ formado (Eq. 7) é menos reativo que o radical hidroxila $\left({ }^{\circ} \mathrm{OH}\right)$, levando a uma menor contribuição nas reações de oxidação de poluentes (DANESHAVAR et al., 2005). Esta reação é favorecida quando $\mathrm{H}_{2} \mathrm{O}_{2}$ está em excesso no meio reacional. 
$\mathrm{O}$ sucesso de aplicação do sistema $\mathrm{UV} / \mathrm{H}_{2} \mathrm{O}_{2}$ depende essencialmente das características do efluente que se pretende tratar e das condições operacionais a serem empregadas. A Tabela 7 apresenta os principais parâmetros de processo que afetam o sistema. As condições ótimas devem ser determinadas para cada caso através de estudos de tratabilidade.

Tabela 7 - Parâmetros de processos que afetam o sistema UV/ $\mathrm{H}_{2} \mathrm{O}_{2}$

\begin{tabular}{ll}
\hline Categorias & Parâmetros \\
\hline Características do efluente & $\begin{array}{l}\mathrm{pH}, \text { absorbância, estrutura química e concentrações de contaminantes, } \\
\text { seqüestradores de radicais livres, cor, turbidez. }\end{array}$ \\
\hline Condições operacionais & $\begin{array}{l}\mathrm{pH} \text {, temperatura, dose de oxidante, espectro de emissão da lâmpada e } \\
\text { intensidade, tempo de residência, modo de operação (batelada e contínuo com } \\
\text { ou sem reciclo), transmissividade de UV, objetivos do tratamento. }\end{array}$ \\
\hline
\end{tabular}

Neste item da REVISÃO BIBLIOGRÁFICA (2.2.1 Sistema UV/ $\mathrm{H}_{2} \mathrm{O}_{2}$ ) serão discutidos os seguintes parâmetros: temperatura, $\mathrm{pH}$, absorbância, seqüestradores de radicais livres, espectro de emissão de energia de lâmpadas na região UV e intensidade. Os demais parâmetros serão discutidos ao longo do texto, quando da discussão dos resultados experimentais.

A estabilidade do $\mathrm{H}_{2} \mathrm{O}_{2}$ varia em função do $\mathrm{pH}$ e da temperatura. Maiores temperaturas e pH básico favorecem sua decomposição em $\mathrm{H}_{2} \mathrm{O}$ e $\mathrm{O}_{2}$ (Eq. 11).

$2 \mathrm{H}_{2} \mathrm{O}_{2} \stackrel{-}{-} \mathrm{OH} \longrightarrow 2 \mathrm{H}_{2} \mathrm{O}+\mathrm{O}_{2}$

A taxa de fotólise do $\mathrm{H}_{2} \mathrm{O}_{2}$ e a conseqüente geração de radical hidroxila parece não ser dependente da temperatura. No entanto, observa-se um aumento da eficiência global do sistema $U \mathrm{U} / \mathrm{H}_{2} \mathrm{O}_{2}$ com o aumento da temperatura. Isto ocorre porque o aumento da temperatura favorece as reações de oxidação, devido ao efeito da temperatura sobre a constante de velocidade, resultando em um aumento da taxa da reação de oxidação. A dependência da constante de velocidade de reação com a temperatura pode ser descrita pela equação de Arrhenius (12):

$$
k(T)=A \cdot \exp \left(\frac{-E_{a}}{R T}\right)
$$

A taxa de fotólise de $\mathrm{H}_{2} \mathrm{O}_{2}$ no meio aquoso parece ser influenciada pelo $\mathrm{pH}$, atingindo seu valor máximo em pH alcalino (LEGRINI; OLIVEROS; BRAUN, 1993). Para os autores supracitados, isto pode ser atribuído à formação do ânion conjugado de $\mathrm{H}_{2} \mathrm{O}_{2}\left(\mathrm{HO}_{2}^{-}\right)$em pH alcalino (Eq. 13):

$$
\mathrm{H}_{2} \mathrm{O}_{2} \rightarrow \mathrm{HO}_{2}^{-}+{ }^{+} \mathrm{H} \quad \mathrm{pK}_{\mathrm{a}}=11,6
$$


O ânion $\mathrm{HO}_{2}{ }^{-}$apresenta maior coeficiente de extinção molar $\left(240 \mathrm{M}^{-1} \mathrm{~cm}^{-1} \mathrm{em}\right.$ $254 \mathrm{~nm})$ em relação ao $\mathrm{H}_{2} \mathrm{O}_{2}\left(18,6 \mathrm{M}^{-1} \mathrm{~cm}^{-1}\right)$, favorecendo a produção de ${ }^{\circ} \mathrm{OH}$ (ANDREOZZI et al., 1999).

Ademais, sabe-se que o peróxido de hidrogênio se decompõe através da reação de dismutação (Eq. 14), com a máxima taxa no $\mathrm{pH}$ de seu valor de $\mathrm{pK}_{\mathrm{a}}$. $\mathrm{H}_{2} \mathrm{O}_{2}+\mathrm{HO}_{2}^{-} \rightarrow \mathrm{H}_{2} \mathrm{O}+\mathrm{O}_{2}+{ }^{\bullet} \mathrm{OH}$

Por outro lado, o ânion $\mathrm{HO}_{2}^{-}$em meio alcalino reage com radical hidroxila $\left(\mathrm{k}_{4}=\right.$ $\left.7,5.10^{9} \mathrm{M}^{-1} \mathrm{~s}^{-1}\right)$ mais rapidamente que o peróxido de hidrogênio $\left(\mathrm{k}_{1}=2,7.10^{7} \mathrm{M}^{-1} \mathrm{~s}^{-1}\right)$, conforme reações apresentadas nas Equações 7 e 10.

Além disso, o pH do efluente controla o equilíbrio de carbonatos, bicarbonatos e ácido carbônico, que é importante parâmetro da eficiência do tratamento, pois os íons carbonatos e bicarbonatos são seqüestradores de radicais hidroxila. A diminuição do pH para uma faixa de 4 a 6 desloca o equilíbrio para a formação de ácido carbônico e conseqüente redução de carbonatos e bicarbonatos.

Portanto, a faixa de $\mathrm{pH}$ ótimo para o sistema $\mathrm{UV} / \mathrm{H}_{2} \mathrm{O}_{2}$ leva em consideração o efeito combinado de: (1) estabilidade de $\mathrm{H}_{2} \mathrm{O}_{2}$ em função do $\mathrm{pH}$; (2) taxa de fotólise de $\mathrm{H}_{2} \mathrm{O}_{2}$ em função do $\mathrm{pH}$, (3) equilíbrio de carbonatos, bicarbonatos e ácido carbônico e (4) características do substrato estudado.

Cisneros; Espinoza e Litter (2002) analisaram a fotodegradação de um corante azo, preto de hispamin, pelo sistema $\mathrm{UV} / \mathrm{H}_{2} \mathrm{O}_{2}$, de acordo com as condições experimentais apresentadas na Tabela 8. Os resultados obtidos por esses autores foram que a reação de fotodegradação mostrou-se mais lenta em pH ácido e que a eficiência do processo aumenta em $\mathrm{pH}$ neutro e, principalmente, alcalino, devido às maiores taxas de fotólise de $\mathrm{H}_{2} \mathrm{O}_{2}$.

Ao estudar a degradação do herbicida ácido acético 2,4-diclorofenóxi em sistema UV/ $\mathrm{H}_{2} \mathrm{O}_{2}$, Chu (2001) observou que o pH ácido favorecia a taxa de reação. Galindo e Kalt (1998) pesquisaram a cinética de oxidação de corante azo em meio aquoso pelo sistema $U V / \mathrm{H}_{2} \mathrm{O}_{2}$. Ao avaliarem o efeito do $\mathrm{pH}$ inicial sobre a cinética, os autores verificaram que a taxa de oxidação caía consideravelmente em pH alcalino, principalmente em torno de 10,5. Em ambos os trabalhos, os autores atribuíram este decréscimo à elevada taxa de decomposição de $\mathrm{H}_{2} \mathrm{O}_{2}$ em $\mathrm{H}_{2} \mathrm{O}$ e $\mathrm{O}_{2}$, em detrimento da produção de radicais hidroxila. 
A eficiência do processo de combinação do $\mathrm{H}_{2} \mathrm{O}_{2}$ com UV depende também da absorção de UV pelos compostos irradiados presentes no efluente e da geração de radical hidroxila a partir do peróxido de hidrogênio. A radiação UV absorvida por qualquer outra substância que não seja $\mathrm{H}_{2} \mathrm{O}_{2}$ deve ser minimizada, uma vez que a oxidação resultante da fotólise direta da matéria orgânica é pequena em relação à oxidação provocada pelos radicais hidroxila formados a partir de $\mathrm{H}_{2} \mathrm{O}_{2}$.

A taxa de uma reação fotoquímica pode ser definida como (BRAUN et al, 1993):

$$
-\frac{d[S]}{d t}=\int_{\lambda_{1}}^{\lambda_{2}} \phi_{-S} P_{a} d \lambda
$$

Em que:

$\mathrm{S}=$ substrato

$\phi_{-s}=$ rendimento quântico de consumo de substrato

$\mathrm{P}_{\mathrm{a}}=$ taxa de absorção de fótons $=\mathrm{P}_{\mathrm{o}}\left(1-10^{-\mathrm{As}}\right)$

$P_{0}=$ taxa de incidência de fótons

$A_{S}=$ absorbância do substrato

$\mathrm{O}$ cálculo de $\mathrm{P}_{\mathrm{a}}$ de acordo com a lei de Beer-Lambert pode somente servir como uma estimativa, uma vez que a irradiação de fótons incidentes chegando em um dado ponto do volume de reação irradiado não pode ser calculado precisamente.

O rendimento quântico, que expressa a quantidade de composto oxidado por unidade de fóton absorvido, para produção de radicais hidroxila a partir de $\mathrm{H}_{2} \mathrm{O}_{2}$, é de aproximadamente 1,0 mol/Einstein, para comprimentos de onda de 254, 308 e 351 nm (CHANG; YOUNG, 2000).

O coeficiente de extinção molar $(\varepsilon)$ denota a intensidade de absorção pela substância para um determinado comprimento de onda. É proporcional à probabilidade de ocorrência de transição eletrônica e pode ser obtido pela lei de Beer-Lambert, $\varepsilon=\mathrm{A} /(\mathrm{cl})$, baseado no caminho óptico da cela de absorção (I), absorbância (A) e concentração da amostra (c) (VERHOEVEN, 1996). O coeficiente de extinção molar de $\mathrm{H}_{2} \mathrm{O}_{2}\left(\varepsilon_{\mathrm{H} 2 \mathrm{O} 2}\right)$ cresce gradualmente em comprimentos de ondas menores, conforme apresentado na Figura 4. Nessa figura, observa-se que o peróxido de hidrogênio não absorve radiações com comprimentos de onda maiores que 300 nm (LEGRINI; OLIVEROS; BRAUN, 1993). 


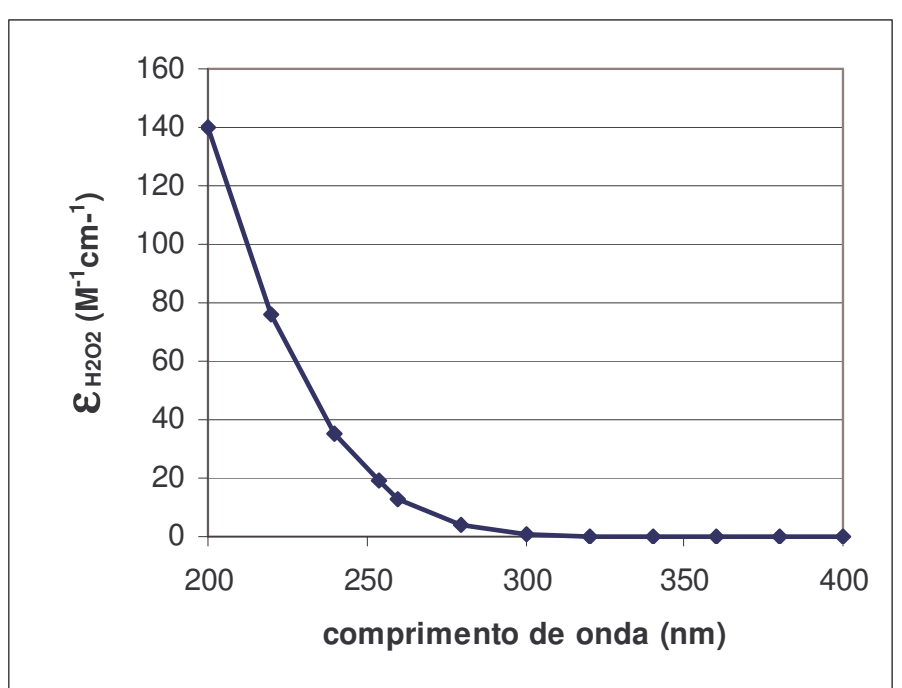

Figura 4 - Coeficiente de extinção molar $\varepsilon_{\mathrm{H} 2 \mathrm{O} 2}\left(\mathrm{M}^{-1} \mathrm{~cm}^{-1}\right)$ em função do comprimento de onda $(\mathrm{nm})$ (EPA, 1998).

Devido ao intervalo de absorção do peróxido de hidrogênio, quando se pretende utilizar o processo $U \mathrm{~V} / \mathrm{H}_{2} \mathrm{O}_{2}$, a lâmpada a ser usada como fonte de UV tem que ser específica para este caso.

Portanto, as características de emissão e geometria da fonte luminosa são fatores importantes para o projeto de um reator fotoquímico e para a adequada eficiência do processo fotoquímico. Para o sistema $U V / \mathrm{H}_{2} \mathrm{O}_{2}$, altas conversões do processo são alcançadas no domínio espectral do UV-C (EPA, 1998).

A radiação ultravioleta (UV) pertence ao espectro eletromagnético e situa-se na faixa de 40 a $400 \mathrm{~nm}$ de comprimento de onda, entre os raios-X e a luz visível. $O$ espectro UV é dividido em (SOBOTKA, 1993 apud TEIXEIRA; JARDIM, 2004):

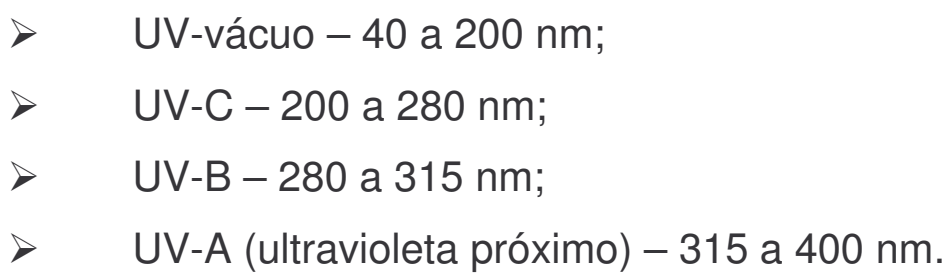

As fontes disponíveis comercialmente para a geração de luz com comprimentos de onda na região do espectro ultravioleta são limitadas por três tipos: lâmpadas de deutério, xenônio e vapor de mercúrio. Entre elas, as de vapor de mercúrio são as mais usadas em aplicações de laboratório e industriais (CAVICCHIOLI; GUTZ, 2003). O princípio de funcionamento das lâmpadas a vapor de mercúrio é baseado na descarga elétrica que resulta na emissão de energia luminosa a partir de átomos de mercúrio excitados pelas colisões resultantes da corrente de elétrons e íons no arco formado entre os eletrodos montados no interior de um bulbo de quartzo, contendo além de uma determinada quantidade do metal, 
um gás nobre, normalmente argônio. O espectro de emissão de energia dessas lâmpadas depende fortemente da pressão dos gases no interior do bulbo de quartzo. A Figura 5 apresenta exemplos de curvas típicas de distribuição espectral de energia de lâmpadas a vapor de mercúrio de baixa pressão (monocromática) e média pressão (policromática).

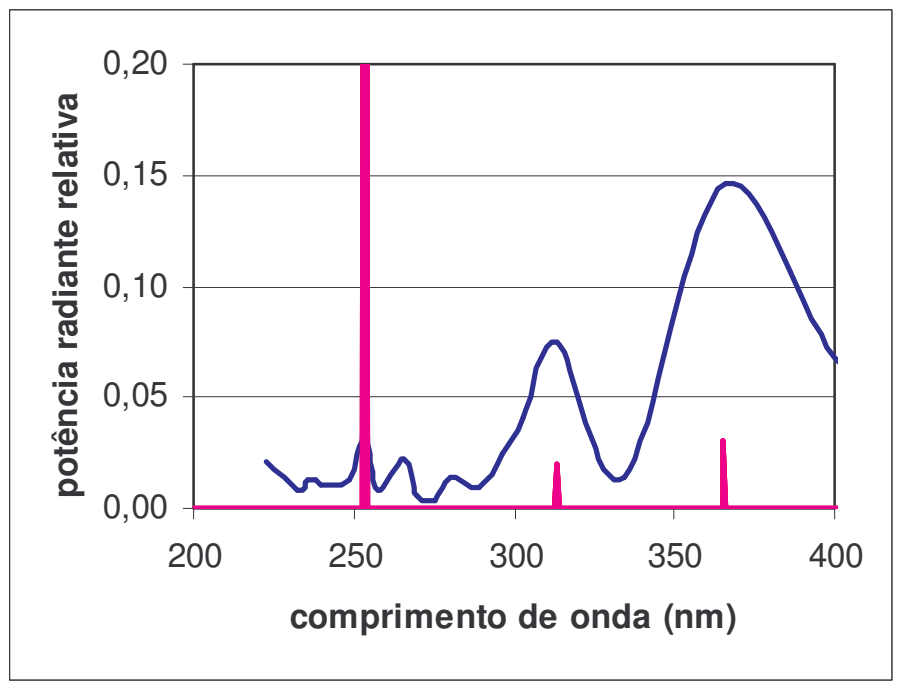

Figura 5 - Curvas típicas de distribuição espectral de energia: (-) lâmpada a vapor de mercúrio de baixa pressão - monocromática (TUV - Philips); (-) lâmpada a vapor de mercúrio de média pressão - policromática (Hanovia - Ace Glass).

Lâmpadas a vapor de mercúrio de baixa pressão são praticamente monocromáticas com emissão em 254 nm, sendo que uma outra linha gerada em $189 \mathrm{~nm}$ é, em lâmpadas convencionais, filtrada pelas paredes do bulbo e pelo $\mathrm{O}_{2}$ atmosférico. Sua eficiência de conversão da potência em radiação UV é melhor do que a das lâmpadas de média e alta pressão que, apesar de apresentarem potência nominal aproximadamente uma ordem de grandeza maior, convertem em luz UV somente cerca de $30 \%$ da potência elétrica consumida. Porém, estas lâmpadas podem não ser a melhor escolha para o processo $\mathrm{UV} / \mathrm{H}_{2} \mathrm{O}_{2}$, devido ao coeficiente de absorção molar de peróxido de hidrogênio no comprimento de onda de $254 \mathrm{~nm}$ ser baixo (18,6 $\mathrm{M}^{-1} \mathrm{~cm}^{-1}$, ANDREOZZI et al., 1999).

Portanto, se lâmpadas a vapor de mercúrio de baixa pressão são utilizadas, é necessária alta concentração de $\mathrm{H}_{2} \mathrm{O}_{2}$ para geração suficiente de radicais hidroxila $\left({ }^{\circ} \mathrm{OH}\right)$. Entretanto, em altas concentrações, $\mathrm{H}_{2} \mathrm{O}_{2}$ pode atuar como seqüestrador de radicais ${ }^{\bullet} \mathrm{OH}$, conforme reações apresentadas nas Equações de 7 a 9, reduzindo a eficiência do sistema $\mathrm{UV} / \mathrm{H}_{2} \mathrm{O}_{2}$, devido à menor disponibilidade desse radical para o processo. Comparando-se as constantes de reações de ataque de ${ }^{\circ} \mathrm{OH}$ aos compostos orgânicos $\left(\mathrm{k} \sim 10^{9} \mathrm{M}^{-1} \mathrm{~s}^{-1}\right)$, conforme apresentado na Tabela 4, com a 
constante de reação de ${ }^{\bullet} \mathrm{OH}$ com $\mathrm{H}_{2} \mathrm{O}_{2}\left(\mathrm{k}=2,7.10^{7} \mathrm{M}^{-1} \mathrm{~s}^{-1}\right)$, apresentada na Eq.(7), percebe-se o quão significativa é a parcela de consumo de ${ }^{\circ} \mathrm{OH}$ com $\mathrm{H}_{2} \mathrm{O}_{2}$ em detrimento do ataque de ${ }^{\bullet} \mathrm{OH}$ aos compostos orgânicos. Para superar esta limitação, lâmpadas de emissão de energia UV em banda larga de alta intensidade e média pressão podem ser usadas (EPA, 1998).

As fontes de média e alta pressão apresentam um espectro de emissão caracterizado por linhas mais alargadas e um fundo contínuo que cobre toda a região UV, inclusive a faixa do ultravioleta próximo (UV-A), além de emitirem radiação na região visível e infravermelho. Estas lâmpadas dissipam uma grande quantidade de calor e atingem temperaturas elevadas $\left(600-800^{\circ} \mathrm{C}\right)$, sendo requerido controle de temperatura para evitar superaquecimento. Processos baseados em lâmpadas a vapor de mercúrio de baixa pressão operam tipicamente a $40^{\circ} \mathrm{C}$ (GONÇALVES, 2004).

A Tabela 8 descreve alguns trabalhos representativos sobre aplicação do sistema $\mathrm{UV} / \mathrm{H}_{2} \mathrm{O}_{2}$ para tratamento de poluentes orgânicos. 
Tabela 8 - Revisão bibliográfica sobre o sistema UV/ $\mathrm{H}_{2} \mathrm{O}_{2}$

\section{Referência Objetivos Condições Experimentais}

Sanz et al., Tratamento de solução com alta

(2003)

concentração de surfactante para aumento da biodegradabilidade. substrato: Linear Aquil-benzenosulfonato, LAS.

Temperatura: ambiente; $\mathrm{pH}=2,2$ a 7,0;

$\left[\mathrm{H}_{2} \mathrm{O}_{2}\right]_{0} /[\mathrm{LAS}]_{0}=2$ a $40 \mathrm{~mol} / \mathrm{mol}$

Reator tubular anular com recirculação de solução: $\mathrm{V}_{\mathrm{R}}{ }^{\mathrm{a}}=0,75 \mathrm{~L} ; \mathrm{V}_{\mathrm{T}}{ }^{\mathrm{b}}=0,25 \mathrm{~L} ; \mathrm{t}^{\mathrm{c}}=60 \mathrm{~min}$; poço:

quartzo; estrutura externa: aço; agitação mecânica no tanque; sem resfriamento.

Lâmpada: BP ${ }^{d} 19 W$ (Hannau T44/NN15)

$\mathrm{I}_{0}{ }^{e}=0,21 \cdot 10^{-6}$ einstein $\mathrm{L}^{-1} \mathrm{~s}^{-1}$ (actinômetro: $\mathrm{H}_{2} \mathrm{O}_{2}$ )

$\mathrm{S}_{\mathrm{o}}{ }^{\mathrm{f}}=1 \mathrm{a} 20 \mathrm{~g} / \mathrm{L} ; \varepsilon_{\mathrm{s}}{ }^{\mathrm{g}}(254 \mathrm{~nm})=641,5 \mathrm{M}^{-1} \mathrm{~cm}^{-1}$

Beltrán; Estudo de efluentes de destilaria Temperatura: $18^{\circ} \mathrm{C} ; \mathrm{pH}=4,0$ e 7,$0 ;\left[\mathrm{H}_{2} \mathrm{O}_{2}\right]_{\circ}=10^{-3} \mathrm{a}$

González, (efluente A) e plantas de $10^{-1} \mathrm{M}$

M. e processamento de tomate

González, J. (efluente B): obtenção de taxa de

F. (1997) oxidação e de parâmetros cinéticos globais.

Parâmetros monitorados: DQO,

COT, absorbância em 254nm $\left(\mu_{\mathrm{T}}\right)$

Reator batelada anular:

$\mathrm{V}_{\mathrm{R}}{ }^{\mathrm{a}}=0,85 \mathrm{~L} ; \mathrm{t}$

externa: vidro.

Lâmpada: BP ${ }^{\mathrm{d}} 15 \mathrm{~W}$ (Hannau)

$\mathrm{I}_{0}{ }^{e}=3,8 \cdot 10^{-6}$ einstein $\mathrm{L}^{-1} \mathrm{~s}^{-1}$ (actinômetro: $\mathrm{H}_{2} \mathrm{O}_{2}$ )

Efluente $\mathrm{A}: \mathrm{DQO}_{0}{ }^{\mathrm{i}}=750$ a $3000 \mathrm{mg} \mathrm{O} / \mathrm{L} ; \mathrm{COT}_{0}{ }^{\mathrm{j}}=$

230 a $930 \mathrm{mg} \mathrm{C} / \mathrm{L} ; \mathrm{pH}=3$ a $5 ; \mu_{\mathrm{To}}{ }^{\mathrm{k}}=0,4$ a $2,3 \mathrm{~cm}^{-1}$

Efluente B: $\mathrm{DQO}_{0}{ }^{\mathrm{i}}=250$ a $960 \mathrm{mg} \mathrm{O} / \mathrm{L} ; \mathrm{COT}_{0}{ }^{\mathrm{j}}=$

\begin{tabular}{lll}
\hline Juang; & Investigação de aplicação de & Temperatura: $30^{\circ} \mathrm{C} ; \mathrm{pH}=1-11 ;\left[\mathrm{H}_{2} \mathrm{O}_{2}\right]_{\circ}=29$ a 294 \\
Tseng e & tratamento UV/ $\mathrm{H}_{2} \mathrm{O}_{2}$ em efluentes & $\mathrm{mM}$ (efluente $\mathrm{A}$ ) e $\left[\mathrm{H}_{2} \mathrm{O}_{2}\right]_{\circ}=7$ a $147 \mathrm{mM}$ (efluente B) \\
Yang (1997) & petroquímicos brutos (A) ou & Reator batelada anular:
\end{tabular}

Yang (1997) petroquímicos brutos (A) ou previamente polido por

biotratamento (B)

Parâmetros monitorados: DQO e

COT. Compostos tóxicos: mono-

(NB), o-cresol (CR) foram, em

alguns ensaios, adicionados para

avaliar potencial de

desintoxicação. 280 a $815 \mathrm{mg} \mathrm{C} / \mathrm{L} ; \mathrm{pH}=6$ a 7,$5 ; \mu_{\mathrm{To}}{ }^{\mathrm{k}}=0,2 \mathrm{a} 0,8 \mathrm{~cm}^{-1}$
$V_{R}{ }^{a}=3 L ; t^{c}=240$ min; poço encamisado

(resfriamento): quartzo; estrutura externa: vidro,

agitação magnética

Lâmpada: BP ${ }^{\mathrm{d}}$ 15W (G15T8 GL-15)

Intensidade $=4,8 \mathrm{~mW} / \mathrm{cm}^{2}$ (radiômetro UVX $254 \mathrm{~nm}$ )

Efluente $\mathrm{A}: \mathrm{DQO}_{0}{ }^{\mathrm{i}}=4800 \mathrm{mg} \mathrm{O} / \mathrm{L} ; \mathrm{COT}_{0}{ }^{\mathrm{j}}=1200 \mathrm{mg}$

$\mathrm{C} / \mathrm{L} ; \mathrm{pH}=8,5$; alcalinidade $=584 \mathrm{mg} / \mathrm{L}$

Efluente B: $\mathrm{DQO}_{0}{ }^{\mathrm{i}}=360 \mathrm{mg} \mathrm{O} \mathrm{O}_{2} / \mathrm{L} ; \mathrm{COT}_{0}{ }^{\mathrm{j}}=130 \mathrm{mg}$

$\mathrm{C} / \mathrm{L} ; \mathrm{pH}=8,5 ;$ alcalinidade $=940 \mathrm{mg} / \mathrm{L}$
Resultados

$\mathrm{X}_{\mathrm{S}}{ }^{\mathrm{h}} \cong 50 \%$ (nos casos mais favoráveis). A oxidação

de LAS por ${ }^{\circ} \mathrm{OH}$ contribuiu com 60 a $97 \%$ de remoção total de LAS. A taxa de oxidação foi ligeiramente maior para $\mathrm{pH}$ mais ácidos. $\mathrm{O}$ aumento da razão $\left[\mathrm{H}_{2} \mathrm{O}_{2}\right]_{0} /[\mathrm{LAS}]_{0}$ aumentou a taxa de oxidação, no entanto para $\left[\mathrm{H}_{2} \mathrm{O}_{2}\right]_{0} /[\mathrm{LAS}]_{0}>15$ não houve incremento significativo na taxa de oxidação. O tratamento melhora a biodegradabilidade $e$ diminui a toxicidade da solução.

Fotólise direta: Efluente $A$ é refratário à fotólise direta em 254nm; Efluente B: $\phi_{B}{ }^{n}(254 \mathrm{~nm})=0,7 \mathrm{a}$ $0,005 \mathrm{~mol} \mathrm{O}_{2} /$ fóton para $\mathrm{DQO}_{0}{ }^{1}=907$ e $105 \mathrm{mg}$ $\mathrm{O}_{2} / \mathrm{L}$.

$\mathrm{UV} / \mathrm{H}_{2} \mathrm{O}_{2}$ : Efluente $\mathrm{A}\left(\triangle \mathrm{DQO}{ }^{\mathrm{I}}=38 \%, \mathrm{DQO}_{0}{ }^{\mathrm{i}}=850\right.$ $\left.m g \mathrm{O}_{2} / \mathrm{L} \mathrm{e}\left[\mathrm{H}_{2} \mathrm{O}_{2}\right]_{0}=10^{-1} \mathrm{M}\right)$. pH inicial não influenciou na oxidação. $\Delta$ COT $^{\mathrm{m}}$ negligenciável. UV/ $\mathrm{H}_{2} \mathrm{O}_{2}$ deve ser combinado com tratamento biológico, pois melhora biodegradabilidade, mas não mineraliza os compostos.

Efluente $\mathrm{A}: \triangle \mathrm{DQO} \mathrm{I}^{\mathrm{e}} \mathrm{\text {e }} \mathrm{COT}^{\mathrm{m}}$ aumentam para

) maiores doses de $\mathrm{H}_{2} \mathrm{O}_{2}$ e diminuem com o aumento de $\mathrm{pH}\left(\triangle \mathrm{DQO}^{\mathrm{l}} \cong 31 \%, \Delta \mathrm{COT}^{\mathrm{m}} \cong 29 \%\right.$ em pH=3 e $\left.\left[\mathrm{H}_{2} \mathrm{O}_{2}\right]_{0}=147 \mathrm{mM}\right)$. Remoção de MBC, NB e CR revela o potencial de desintoxicação.

Efluente $\mathrm{B}$ : $U V / \mathrm{H}_{2} \mathrm{O}_{2}$ em $\mathrm{pH}=8,5$ não foi efetivo devido à alta alcalinidade $\left(\mathrm{CO}_{3}{ }^{2-}, \mathrm{HCO}_{3}{ }^{-}\right)$, em $\mathrm{pH}=$ 3 obteve-se remoções de $\triangle \mathrm{DQO}^{1} \cong 50 \%, \Delta \mathrm{COT}^{\mathrm{m}}$ $\cong 15 \%$ para $\left[\mathrm{H}_{2} \mathrm{O}_{2}\right]_{0} \geq 29 \mathrm{mM}$, atendendo padrões locais de lançamento.

continua

${ }^{\mathrm{a}} \mathrm{V}_{\mathrm{R}}$ : volume do reator, ${ }^{\mathrm{b}} \mathrm{V}_{\mathrm{T}}$ : volume do tanque, ${ }^{\mathrm{c}}$ t: tempo de reação, ${ }^{\mathrm{d}} \mathrm{BP}$ : lâmpada a vapor de mercúrio de baixa pressão, ${ }^{\mathrm{e}} \mathrm{I}_{\mathrm{o}}$ : fluxo de radiação incidente, ${ }^{\mathrm{f}} \mathrm{S}_{\mathrm{o}}$ : concentração inicial de substrato, ${ }^{\mathrm{g}} \mathrm{E}$ : coeficiente de extinção molar, ${ }^{\mathrm{h}} \mathrm{X}$ : remoção de poluentes, ${ }^{\mathrm{i}} \mathrm{DQO}$ : demanda química de oxigênio, ${ }^{\mathrm{j}} \mathrm{COT}$ : carbono orgânico total, ${ }^{\mathrm{k}} \mu_{\mathrm{T}}$ : absorbância em $254 \mathrm{~nm},{ }^{\mathrm{I}} \Delta \mathrm{DQO}$ : remoção de DQO, ${ }^{\mathrm{m}} \Delta \mathrm{COT}$ : remoção de COT, ${ }^{\mathrm{n}} \phi$ : rendimento quântico, ${ }^{\circ} \mathrm{MP:}$ lâmpada a vapor de mercúrio de média pressão, ${ }^{\mathrm{p}} \mathrm{k}_{1}$ : constante de reação pseudo $1^{\mathrm{a}}$ ordem, ${ }^{\mathrm{q}} \mathrm{HP}$ : peróxido de hidrogênio, ${ }^{\mathrm{r}} \mathrm{k}$ : constantes de reação com ${ }^{\circ} \mathrm{OH}$ 
continuação

Einschlag et Análise do efeito das de tratamento. Correlação de

condições ótimas com absorção do substrato e reatividade com -OH.

Parâmetros monitorados: COD Compostos nitroaromáticos:

nitrobenzeno (NBE), 1-cloro-2,4dinitrobenzeno (CDNB), 2,4-dinitro fenol (DNP) e 4-nitrofenol (PNP).

\section{Cater et al. Determinação da eficiência de}

(2000) tratamento de MTBE, presente em 9,3m águas subte por gasolina.

Parâmetros monitorados: Metil terc-butil éter (MTBE) al. (2002) concentrações de $\mathrm{H}_{2} \mathrm{O}_{2}$ e

contaminantes sobre a eficiência

Produtos intermediários (ex. $\mathrm{NO}_{3}{ }^{-}$)

$\mathrm{pH}=2,5 ;\left[\mathrm{H}_{2} \mathrm{O}_{2}\right]_{\mathrm{o}}=5,5$ a $600 \mathrm{mM} ; \mathrm{t}^{\mathrm{c}}=2 \mathrm{a} 3 \mathrm{~h}$

Reatores (batelada anular):

\begin{tabular}{lcc}
\hline & Reator $1^{*}$ & Reator $2^{*}$ \\
\hline VR a (L) & 0,75 & 0,80 \\
\hline Lâmpada MP o & $125 \mathrm{~W}$ Philips & $150 \mathrm{~W}$ Hanau \\
\hline lo e (einstein/s) & $9,8.10^{-6 * *}$ & $12.10^{-6 * *}$ \\
\hline T $\left({ }^{\circ} \mathrm{C}\right)$ & $25^{\star * *}$ & $21^{* * *}$
\end{tabular}

* poço em quartzo, agitação por borbulhamento de ar sintético $\left(21 \% \mathrm{O}_{2} \text { em N }\right)_{2}$; ** 200-450nm, actinômetro: ferroxilato de potássio. ${ }^{* * *}$ Controle por $r$ : taxa de reação, $\mathrm{R}_{\mathrm{OPT}}=\left[\mathrm{H}_{2} \mathrm{O}_{2}\right]_{\circ \mathrm{OPT}} / \mathrm{c}_{\mathrm{o}}$ (ótimo) banho termostático.

$\mathrm{NBE}=(1,5$ a 19$) \cdot 10^{-4} \mathrm{M} ; \mathrm{CDNB}=(1,5$ a 5,2$) \cdot 10^{-4} \mathrm{M}$ $\mathrm{DNP}=(2,2$ a 8,1$) \cdot 10^{-4} \mathrm{M} ; \mathrm{PNP}=(2,50$ a 18$) \cdot 10^{-4} \mathrm{M}$

Temperatura: não reportada; $\mathrm{pH}=7 ;\left[\mathrm{H}_{2} \mathrm{O}_{2}\right]_{0}=0,3 \mathrm{a}$ Reator batelada anular:

$V_{R}{ }^{a}=40 L ; t^{c}=2,4$ a 10,8 mim (dose $U V=1$ a 4,5 $\mathrm{kWh} / \mathrm{m}^{3}$ ); poço: quartzo; estrutura externa: aço inox agitador mecânico, resfriamento: serpentina. Lâmpada: MP ${ }^{\circ} 1 \mathrm{~kW}$ (Rayox-Calgon Carbon Corporation)

MTBE diluído em água potável $(\mathrm{pH}=7$, alcalinidade $=$ $80 \mathrm{mg} / \mathrm{L}) ; \mathrm{MTBE}=0,08$ a $85 \mathrm{mg} / \mathrm{L}$

Arslan et al. Desempenho de tratamento e (2000) remoção de cor de efluentes têxteis (corantes) através divers POAs (ex. UV-C/ $/ \mathrm{H}_{2} \mathrm{O}_{2}$, UV-CFenton). Considerações Temperatura: $21^{\circ} \mathrm{C} ;\left[\mathrm{H}_{2} \mathrm{O}_{2}\right]_{0}=1$ a $25 \mathrm{mM}$

UV $/ \mathrm{H}_{2} \mathrm{O}_{2}$ : $\mathrm{pH}=7$, Foto-fenton: $\mathrm{pH}=2,8,\left[\mathrm{Fe}^{2+}\right]_{0}=0,5 \mathrm{mM}$ Reator cônico com lâmpada imersa: $\mathrm{V}_{\mathrm{R}}{ }^{\mathrm{a}}=4 \mathrm{~L} ; \mathrm{t}=60$ mim; poço: quartzo; estrutura externa: vidro, agitador magnético, sem resfriamento.

econômicas

Lâmpada: $\mathrm{BP}^{\mathrm{d}} 25 \mathrm{~W}$ (Hanovia)

Absorbância em $254 \mathrm{~nm}\left(\mathrm{ABS}_{254}\right)$ e $\mathrm{I}_{0}{ }^{\mathrm{e}}=4,8.10^{-6}$ einstein $\mathrm{L}^{-1} \mathrm{~s}^{-1}$ (actinômetro: $600 \mathrm{~nm}\left(\mathrm{ABS}_{600}\right)$
Fotólise direta proporciona remoção de até $4 \%$. Completa remoção dos compostos nitroaromáticos: mecanismo envolvendo substituição eletrofílica no estágio inicial de reação (formação de $\mathrm{NO}_{3}{ }^{-}$).

Modelos propostos compatível com os resultados experimentais. (ver notas e, g, n, r no rodapé)

Cinética baseada na taxa de oxidação inicial (constante pseudo $1^{\text {a }}$ ordem, $\mathrm{k}_{1}{ }^{\prime} \mathrm{p}$ ), apropriado o uso de $\mathrm{E}_{\mathrm{EO}}$ (energia elétrica necessária para redução de concentração de poluente por 1 ordem de magnitude)

$\mathrm{MTBE}=12 \frac{\mathrm{mg}}{\mathrm{L}} \rightarrow \mathrm{K}_{1}{ }^{\mathrm{p}}=1 \mathrm{~min}^{-1} ; \mathrm{E}_{\mathrm{EO}}=1,4 \frac{\mathrm{kWh}}{\mathrm{m}^{3} \text { ordem }}$

$\mathrm{MTBE}=85 \frac{\mathrm{mg}}{\mathrm{L}} \rightarrow \mathrm{k}_{1}{ }^{\mathrm{p}}=0,2 \mathrm{~min}^{-1} ; \mathrm{E}_{\mathrm{EO}}=7,5 \frac{\mathrm{kWh}}{\mathrm{m}^{3} \mathrm{ordem}}$

Tratamento adequado para remoção de cor e

mineralização parcial de compostos. UV/ $\mathrm{H}_{2} \mathrm{O}_{2}$ fol relativamente mais lento.

$\Delta \mathrm{ABS}_{254}=86 \%, \Delta \mathrm{COT}=31 \%$.

$0,5 \mathrm{mM} \mathrm{Fe}^{2+} / 10 \mathrm{mM} \mathrm{H}_{2} \mathrm{O}_{2} / \mathrm{UV}, \mathrm{pH}=2.8 \rightarrow \mathrm{k}_{1}{ }^{\prime} \mathrm{p}=1,2 \mathrm{~min}^{-1}$, $\Delta \mathrm{ABS}_{254}=89 \%, \Delta \mathrm{COT}=32 \%$. $r=\frac{2 I_{0} \Phi_{\mathrm{HP}} \epsilon R}{(\epsilon R+1)(k R+1)} \quad R_{O P T}=\sqrt{\frac{1}{k \epsilon}}=\sqrt{\frac{k_{\mathrm{S}} \epsilon_{\mathrm{S}}}{k_{\mathrm{HP}} \epsilon_{\mathrm{HP}}}}$ $25 \mathrm{mM} \mathrm{H}_{2} \mathrm{O}_{2} / \mathrm{UV}, \mathrm{pH}=7 \rightarrow \mathrm{k}_{1}{ }^{\prime} \mathrm{p}=0,1 \mathrm{~min}^{-1}$ $\left.\mathrm{H}_{2} \mathrm{O}_{2}\right) \rightarrow 2,26 \mathrm{~W} / \mathrm{L}$ Efluente simulado: $\mathrm{DQO}=44 \mathrm{mg} / \mathrm{L}, \mathrm{COT}=31 \mathrm{mg} / \mathrm{L}$, $\mathrm{pH}=11, \mathrm{ABS}_{254}=47 \mathrm{~m}^{-1}, \mathrm{ABS}_{254}=38 \mathrm{~m}^{-1}$

${ }^{\mathrm{a}} \mathrm{V}_{\mathrm{R}}$ : volume do reator, ${ }^{\mathrm{b}} \mathrm{V}_{\mathrm{T}}$ : volume do tanque, ${ }^{\mathrm{c}} \mathrm{t}$ : tempo de reação, ${ }^{\mathrm{d}} \mathrm{BP}$ : lâmpada a vapor de mercúrio de baixa pressão, ${ }^{\mathrm{e}} \mathrm{I}_{0}$ : fluxo de radiação incidente, ${ }^{\mathrm{f}} \mathrm{S}_{\mathrm{o}}$ : concentração inicial de substrato, ${ }^{\mathrm{g}} \mathrm{E}$ : coeficiente de extinção molar, ${ }^{\mathrm{h}} \mathrm{X}$ : remoção de poluentes, ${ }^{\mathrm{i}} \mathrm{DQO}$ : demanda química de oxigênio, ${ }^{\mathrm{j}} \mathrm{COT}$ : carbono orgânico total, ${ }^{\mathrm{k}} \mu_{\mathrm{T}}$ : absorbância em $254 \mathrm{~nm},{ }^{\mathrm{I}} \Delta \mathrm{DQO}$ : remoção de DQO, ${ }^{\mathrm{m}} \Delta \mathrm{COT}$ : remoção de COT, ${ }^{\mathrm{n}} \phi$ : rendimento quântico, ${ }^{\circ} \mathrm{MP:}$ lâmpada a vapor de mercúrio de média pressão, ${ }^{\mathrm{p}} \mathrm{k}_{1}$ : constante de reação pseudo $1^{\mathrm{a}}$ ordem, ${ }^{\mathrm{q}} \mathrm{HP}$ : peróxido de hidrogênio, ${ }^{\mathrm{r}} \mathrm{k}$ : constantes de reação com ${ }^{\circ} \mathrm{OH}$ 
Um certo número de estudos enfoca o tratamento de compostos orgânicos em solução e de águas subterrâneas contaminadas. Entretanto, praticamente não existem relatos sobre tratamentos de efluentes petroquímicos por processo $U V / \mathrm{H}_{2} \mathrm{O}_{2}$ na literatura. Juang; Tseng e Yang (1997) mencionam em seu trabalho o uso do processo $\mathrm{UV} / \mathrm{H}_{2} \mathrm{O}_{2}$ para tratamento de efluentes petroquímicos como tratamento terciário ou pré-tratamento.

Stepnowiski et al (2002) examinaram o emprego do sistema $\mathrm{UV} / \mathrm{H}_{2} \mathrm{O}_{2}$ como uma técnica de tratamento de efluentes gerados em refinaria de petróleo, previamente submetidos a um tratamento físico-químico. A degradação dos contaminantes presentes no efluente foi avaliada através da concentração de hidrocarbonetos totais de petróleo (TPH), diclorometano (DCM), dicloroetano (DCE) e terc-butil-metil éter (tBME), na presença e na ausência de radiação UV e concentrações variadas de $\mathrm{H}_{2} \mathrm{O}_{2}(1,17 ; 3,52 ; 5,88$ e 11,76 mM). Na ausência de UV, o TPH foi o composto mais facilmente removido mediante baixas concentrações de $\mathrm{H}_{2} \mathrm{O}_{2}$. A remoção de DCM foi relativamente baixa devido a sua estabilidade. Para os outros compostos, a degradação foi mais eficiente em concentrações de $\mathrm{H}_{2} \mathrm{O}_{2}$ mais elevadas. Os autores concluíram que, para o efluente estudado a radiação UV não foi essencial, apesar de acelerar o processo de degradação.

Um grande número de estudos e aplicações bem sucedidas do sistema $\mathrm{UV} / \mathrm{H}_{2} \mathrm{O}_{2}$ já foi relatado para diversas situações, como o tratamento de pigmentos (ARSLAN et al., 2000), águas subterrâneas contaminadas por gasolina (CATER et al., 2000), compostos fenólicos (BELTRÁN; GONZÁLEZ, M.; GONZÁLEZ, J. F., 1997), compostos nitro-aromáticos (EINSCHLAG et al., 2002), benzeno, cloroetano, pesticidas e cetonas (CLARKE; KNOWLES, 1982; GLAZE; LAY; KANG, 1987). O sucesso do sistema $\mathrm{UV} / \mathrm{H}_{2} \mathrm{O}_{2}$ está fundamentado no fato de que as constantes de reação do radical hidroxila com a maioria dos poluentes são muito altas. Os radicais hidroxila geralmente reagem milhões a bilhões de vezes mais rápido do que outros oxidantes químicos como ozônio e peróxido de hidrogênio.

No trabalho de Beltrán; González, M. e González, J. F. (1997) um mecanismo proposto de degradação da teor de matéria orgânica mostra que além do ataque por radicais hidroxila, o desaparecimento de contaminantes pode ser atribuído à fotólise direta. Os autores estudaram o efeito da irradiação UV na remoção de poluentes em efluentes de destilaria e plantas de processamento de tomate, que contém, entre outras substâncias, fenóis e compostos insaturados. Resultados obtidos de 
experimentos feitos em fotoreator anular operando em batelada (volume: $850 \mathrm{~mL}$, potência da lâmpada UV-254nm: 15W) revelaram redução de DQO de 4 a 18\%, dependendo da DQO inicial (105 e $907 \mathrm{mgO}_{2} / \mathrm{L}$, respectivamente) e variação desprezível de COT. No entanto muitos autores têm monstrado que UV sozinho não decompõe a maioria da matéria orgânica ou a faz em baixíssimas taxas (SANZ et al.,2002b; BELTRÁN; GONZÁLEZ, M.; GONZÁLEZ, J. F., 1997). Acero et al. (2004) realizaram experimentos apenas com UV em efluente contendo ácidos fenólicos, pentaclorofenol e entre outros contaminantes (fotoreator anular, volume: $1 \mathrm{~L}$, potência da lâmpada a vapor de mercúrio de alta pressão: 150W) obtendo remoções desprezíveis da matéria orgânica. Segundo explicações dos autores, isso ocorre porque os compostos estudados são resistentes à ação individual de radiação UV. Embora a fotólise direta não remova quantidades significativas de compostos orgânicos da água, ela é eficiente no processo de desinfecção.

As vantagens do processo UV/ $\mathrm{H}_{2} \mathrm{O}_{2}$ são: (1) o fácil manuseio, baixo custo do oxidante $\left(\mathrm{H}_{2} \mathrm{O}_{2}\right)$, bem como sua solubilidade muito grande em água e possibilidade de estoque no local, (2) o emprego de reatores de simples construção, já que se opera a baixas pressões e temperaturas. Além disso, este processo não necessita de unidades de separação após o tratamento, pois não produz lodo (ARSLAN et al., 2000), pois pode oxidar os contaminantes, e justamente por causa disso, tornam-se mais competitivos economicamente em relação a tecnologias de "air stripping" e adsorção em carvão ativado (VENKATADRI; PETERS, 1993). De acordo com os autores recém citados, o sistema $\mathrm{UV} / \mathrm{H}_{2} \mathrm{O}_{2}$ pode também ser empregado para tratamento de poluentes em fase gasosa, com taxas de degradação superiores às obtidas no processo em fase aquosa, possivelmente devido à menor absorção de UV pelo ar, aumento da concentração de oxigênio molecular disponível e às mobilidades maiores de reagentes e intermediários.

O sistema $U V / \mathrm{H}_{2} \mathrm{O}_{2}$ apresenta algumas limitações. A principal desvantagem é o baixo coeficiente de absorção do $\mathrm{H}_{2} \mathrm{O}_{2}$ e rendimento quântico da produção de radicais hidroxila, no comprimento de onda de $254 \mathrm{~nm}$, o que diminui a eficiência global do processo (ANDREOZZI et. al., 1999). A taxa de oxidação do poluente é limitada pela taxa de formação dos radicais hidroxila e é dependente da matéria orgânica presente e da quantidade de oxidante adicionado ao sistema. Além disso, a fotólise do peróxido de hidrogênio pode ser afetada pela presença em solução de partículas suspensas e ou espécies que absorvem a radiação UV incidente no 
sistema. Como conseqüência, a parcela de energia UV disponível para a formação de radicais hidroxila a partir da fotólise de $\mathrm{H}_{2} \mathrm{O}_{2}$ diminui, reduzindo dessa maneira a eficiência do processo de oxidação da matéria orgânica (GLAZE; LAY; KANG, 1995). Por isso, o processo necessita de uma etapa prévia de filtração para a remoção de sólidos suspensos. A presença de espécies reativas em solução, tais como: carbonato $\left(\mathrm{CO}_{3}{ }^{2-}\right)$, bicarbonato $\left(\mathrm{HCO}_{3}{ }^{-}\right)$, substâncias húmicas, ou íons fosfato, pode afetar a taxa de degradação do poluente devido ao consumo dos radicais hidroxila. Por exemplo, as constantes cinéticas de reação de carbonatos e bicarbonatos com •OH são de $1,5.10^{7} \mathrm{M}^{-1} \mathrm{~s}^{-1}$ e 4,2.10 $0^{8} \mathrm{M}^{-1} \mathrm{~s}^{-1}$, respectivamente (CRITTENDEN et al., 1999). Venkatadri e Peters (1993) citaram em seu trabalho que compostos inorgânicos presentes em solução, tais como sais de ferro e cálcio, podem precipitar quando expostos à radiação UV, impregnando a camisa da lâmpada e afetando a quantidade de radiação disponível para o tratamento.

Projetos de implantação de sistema $\mathrm{UV} / \mathrm{H}_{2} \mathrm{O}_{2}$ para degradação de compostos orgânicos estão disponíveis atualmente em escala comercial. As principais empresas e as tecnologias oferecidas por elas são: (1) Calgon Carbon Corporation: perox-pure $^{\mathrm{TM}}$ e Rayox ${ }^{\circledR}$; (2) Magnum Water Technology, Inc.: CAV-OX ${ }^{\circledR}$; (3) WEDECO UV Systems: sistema UV/ $\mathrm{H}_{2} \mathrm{O}_{2}$; (4) U.S. Filter/Zimpro, Inc.: $\mathrm{UV} / \mathrm{H}_{2} \mathrm{O}_{2} / \mathrm{O}_{3}$; e (5) Hydroxyl Industrial Systems Inc.: Hydroxyl UVP. A Tabela 9 apresenta dados de desempenho de sistemas comerciais aplicados em tratamentos de águas contaminadas por diversos tipos de poluentes típicos encontrados em águas subterrâneas e efluentes industriais e seus custos aproximados. 
Tabela 9 - Tratamento de águas contaminadas através de sistemas $\mathrm{UV} / \mathrm{H}_{2} \mathrm{O}_{2}$ comerciais (Adaptado de EPA, 1998)

\begin{tabular}{|c|c|c|c|c|}
\hline \multirow{2}{*}{ Sistema } & \multicolumn{3}{|c|}{ Dados de Desempenho } & \multirow{2}{*}{$\begin{array}{c}\text { Custos Aproximados } \\
\text { US\$ (1998) }\end{array}$} \\
\hline & Contaminante & Concentração & Remoção (\%) & \\
\hline \multirow{5}{*}{$\begin{array}{l}\text { Calgon } \\
\text { perox-pure }{ }^{\mathrm{TM}}\end{array}$} & Acetona & $20 \mathrm{mg} / \mathrm{L}$ & $>97,5$ & \multirow[t]{2}{*}{$\$ 1,10 / \mathrm{m}^{3}(\mathrm{O} \& \mathrm{M})$} \\
\hline & Álcool isopropil & $20 \mathrm{mg} / \mathrm{L}$ & $>97,5$ & \\
\hline & Benzeno & $52 \mathrm{mg} / \mathrm{L}$ & $>96$ & \multirow{3}{*}{$\begin{array}{c}\$ 0,08(\mathrm{O} \& \mathrm{M})^{1} \text { a } \$ 1,50 / \mathrm{m}^{3} \\
\text { (capital e O\&M) }\end{array}$} \\
\hline & 1,2-Dicloroeteno & 200 a $11.000 \mathrm{mg} / \mathrm{L}$ & $>99 a>99,9$ & \\
\hline & Clorobenzeno & $3100 \mathrm{mg} / \mathrm{L}$ & $>99,9$ & \\
\hline \multirow{4}{*}{$\begin{array}{l}\text { Calgon } \\
\text { Rayox }^{\circledR}\end{array}$} & DQO & $1000 \mathrm{mg} / \mathrm{L}$ & $\mathrm{Nr}^{4}$ & \multirow{3}{*}{$\begin{array}{c}\$ 0,83 \text { a } \$ 150 / \mathrm{m}^{3} \text { (capital e } \\
\text { O\&M) }\end{array}$} \\
\hline & NDMA $^{2}$ & $30 \mu \mathrm{g} / \mathrm{L}$ a $1,400 \mathrm{mg} / \mathrm{L}$ & $>98,3$ a >99,9 & \\
\hline & UDMH $^{3}$ & $6.000 \mathrm{mg} / \mathrm{L}$ & $\mathrm{Nr}^{4}$ & \\
\hline & 1,2-Dicloroeteno & $810 \mathrm{mg} / \mathrm{L}$ & 91,4 & $\$ 0,09 / \mathrm{m} 3(\mathrm{O} \& \mathrm{M})^{1}$ \\
\hline \multirow{4}{*}{$\begin{array}{l}\text { Magnum CAV } \\
O X^{\boxplus}\end{array}$} & Fenol & $20 \mathrm{mg} / \mathrm{L}$ & $>99,9$ & \multirow[t]{2}{*}{$\mathrm{Nr}^{4}$} \\
\hline & Salmonela & $10^{-6}$ UFC $/ \mathrm{mL}^{5}$ & $>99,9$ & \\
\hline & Benzeno & 250 a $500 \mathrm{mg} / \mathrm{L}$ & 99,8 & \multirow{2}{*}{$\begin{array}{c}\$ 1,50 / \mathrm{m}^{3} \\
\text { (capital e O\&M) }^{1}\end{array}$} \\
\hline & Tetracloroeteno & 1500 a $2000 \mathrm{mg} / \mathrm{L}$ & 99,8 & \\
\hline \multirow[t]{4}{*}{ WEDECO } & Benzeno & $310 \mathrm{mg} / \mathrm{L}$ & 93 & \multirow[t]{4}{*}{$\$ 0,39 / \mathrm{m}^{3}(\mathrm{O} \& \mathrm{M})^{1}$} \\
\hline & 1,2-Dicloroetano & $54 \mathrm{mg} / \mathrm{L}$ & 9 & \\
\hline & cis-1,2-Dicloroeteno & $48 \mathrm{mg} / \mathrm{L}$ & $>87$ & \\
\hline & Etilbenzeno & $41 \mathrm{mg} / \mathrm{L}$ & 92 & \\
\hline
\end{tabular}

O\&M: Operação e Manutenção, ${ }^{2}$ NDMA: N-nitro-sódio-dimetilamina, ${ }^{3}$ UDMH: Unsymmetrical dimethylhydrazine, ${ }^{4} \mathrm{Nr}$ : Não reportado, ${ }^{5}$ UFC: unidades formadoras de colônias.

\subsubsection{Estudos sobre a degradação foto-oxidativa de Polipropileno}

O polipropileno (PP) é um polímero termoplástico de estrutura semicristalina do grupo das poliolefinas, de massa molar entre 80.000 e 500.000 (Strapasson, 2004), produzido a partir de monômeros de propileno, também chamado de propeno. $\mathrm{O}$ propeno é um hidrocarboneto incolor e gasoso, de fórmula: $\mathrm{CH}_{3}-\mathrm{CH}=\mathrm{CH}_{2}$, alceno obtido do petróleo por quebra de cadeias maiores de alcanos.

Os tipos de polipropileno fabricados na Suzano Petroquímica englobam Homopolímeros, Copolímeros Randômicos e Copolímeros Heterofásicos. Os Homopolímeros são produzidos pela polimerização única do propeno e apresentam alta cristalinidade, rigidez, dureza e resistência ao calor. Os Copolímeros Randômicos são obtidos quando se adiciona ao propeno um segundo monômero (normalmente eteno) no reator. As moléculas de eteno são inseridas aleatoriamente, o que reduz a cristalinidade do material. Os Copolímeros Randômicos são mais resistentes ao impacto à temperatura ambiente que os homopolímeros. Os Copolímeros Heterofásicos (muitas vezes também chamados de Copolímeros de 
Impacto ou de Bloco) são produzidos em dois reatores em série, onde no primeiro se polimeriza somente o propeno e no segundo uma fase elastomérica composta de propeno e eteno. Por apresentar, então, estas duas fases os copolímeros heterofásicos perdem transparência, porém apresentam elevada resistência ao impacto tanto à temperatura ambiente como a baixas temperaturas.

De acordo com Lindén et al. (1993), as reações primárias envolvidas na degradação foto-oxidativa de quase todos os polímeros seguem as seguintes etapas:

- Iniciação: formação de radicais poliméricos

- Propagação: reação dos radicais poliméricos livres com oxigênio e a produção de radicais de óxido e peróxido de polímeros, resultando em cisão de cadeia.

- Terminação: reação de radicais poliméricos livres resultando em ligações cruzadas.

O PP é um polímero altamente suscetível à fotodegradação, especialmente na presença de $\mathrm{H}_{2} \mathrm{O}_{2}$. Radicais hidroxila $\left({ }^{\circ} \mathrm{OH}\right)$, gerados pela fotólise de peróxido de hidrogênio na presença de PP, abstraem hidrogênio dos grupos metil $\left(-\mathrm{CH}_{3}\right)$ mais facilmente do que dos grupos metilenos $\left(=\mathrm{CH}_{2}\right)$, gerando assim radicais livres que são capazes de reagir com oxigênio e formar peróxidos e hidroperóxidos, que por sua vez produzem mais radicais livres ocasionando a cisão das cadeias. A ruptura das ligações $\mathrm{C}-\mathrm{H}$ do carbono primário ocorre preferencialmente, pois possui ligações mais fracas que os demais carbonos, e também pode ser causada pela energia absorvida por influência de calor e de luz (LINDÉN et al., 1993; STRAPASSON, 2004). Lindén et al. (1993) propõem o mecanismo de ataque do ácido polimetacrílico por radical hidroxila conforme Eq. ( 17 ). Este composto está ligado ao grupo funcional carboxila $(-\mathrm{COOH})$.<smiles>[CH]C([CH])(CCC(C(=O)O)C(=O)O)C(=O)O</smiles> 
Fazendo uma analogia com o polipropileno, tem-se:<smiles>[CH2]C([CH2+])CC[OH2+]</smiles>

Lindén et al. (1993) realizaram experimentos com poliacrilamida (PAA) e poli(óxido de etileno) (PEO) dissolvido em $\mathrm{H}_{2} \mathrm{O}_{2}$ (30\% em massa) e irradiação UV (254 nm) nos quais foi observada uma rápida degradação oxidativa de ambos os polímeros. As amostras de PAA e PEO foram simultaneamente expostas à fotólise direta (sob radiação UV) e à ação dos radicais hidroxila $\left(\mathrm{HO}^{\bullet}\right)$ e hidroperóxidos $\left(\mathrm{HO}_{2}{ }^{\circ}\right)$. No entanto, a irradiação UV de PAA e PEO em água não provocou degradação significativa.

\subsubsection{Processo contínuo de fotodegradação}

A maioria dos trabalhos apresentados na literatura relata estudos de fotodegradação em escala de bancada e operação em batelada. Somente um limitado número de estudos em reatores em escala piloto ou industrial e operação contínua tem sido reportado (PAREEK; BRUNGS; ADESINA, 2001; LIRA et al., 2006b). A caracterização dos efeitos das variáveis, tais como intensidade de luz, $\mathrm{pH}$, oxidante e concentração de substratos em reatores de bancada, tende ser mais complexa em reatores em escala maior.

A Tabela 10 uma compilação da bibliografia sobre os processos oxidativos avançados aplicados em reatores contínuos.

Shen e Wang (2002) estudaram a aplicabilidade e eficiência de remoção de pigmentos em solução aquosa por meio do sistema $U V / \mathrm{H}_{2} \mathrm{O}_{2}$ em reatores anulares contínuos (0,3 a 1,3 L) e desenvolveram um sistema de equações a fim de prever o comportamento da destruição de pigmentos em variadas condições operacionais.

Segundo os autores supracitados, muitos dos trabalhos passados sobre tratamento de efluentes contendo pigmentos pelo sistema $U V / \mathrm{H}_{2} \mathrm{O}_{2}$ são baseados em descrições fenomenológicas de remoção de poluentes em reator batelada. $O$ estudo do desenvolvimento de equações de projeto em fotoreatores contínuos é 
escasso. Grande parte das pesquisas de modelagem de fotoreatores foi direcionada ao desenvolvimento de expressões para distribuição de intensidade de luz em reatores de configurações simples. Modelos também foram desenvolvidos para analisar o problema de irradiação em diferentes geometrias: transversal, axial ou pontualmente (SHEN; WANG, 2002).

Daneshvar et al. (2005) investigaram o uso do tratamento $\mathrm{UV} / \mathrm{H}_{2} \mathrm{O}_{2}$ em reatores tubulares contínuos em função da concentração de oxidante, comprimento do reator, vazão e intensidade de luz. Esse processo de tratamento pode ser usado para a completa remoção do poluente usado. No entanto sua eficiência depende dos parâmetros operacionais, aumentando quando a concentração de $\mathrm{H}_{2} \mathrm{O}_{2}$ e a intensidade de luz aumentam e diminuindo quando a vazão aumenta.

Tabela 10 - Estudos de reatores contínuos para o sistema UV/ $\mathrm{H}_{2} \mathrm{O}_{2}$

\begin{tabular}{|c|c|c|c|}
\hline Referência & composto & Condições experimentais & Resultados \\
\hline $\begin{array}{l}\text { Shen e } \\
\text { Wang } \\
(2002)\end{array}$ & $\begin{array}{l}\text { Pigmento } \\
\text { "Direct } \\
\text { Yellow } 86 \text { ". } \\
\mathrm{C}_{\mathrm{o}}=50 \pm 0,3 \\
\mathrm{mg} / \mathrm{L}\end{array}$ & $\begin{array}{l}\text { Descrição do reator: Fotoreator anular, } \\
\text { tubo interno de quartzo e tubo externo de } \\
\text { pirex. } \\
\text { Volume útil: entre } 0,3 \text { e } 1,3 \mathrm{~L} \text {. } \\
\text { Fonte de radiação: Lâmpada a vapor de } \\
\text { mercúrio de baixa pressão com emissão } \\
\text { em } 254 \mathrm{~nm} \text { e máxima saída } 5,3 \mathrm{~W} \text {. } \\
\text { Intensidade de UV ajustada por } \\
\text { transformador de voltagem variável (I = } 65 \\
\text { a } 105 \mathrm{~W} / \mathrm{m}^{2} \text { ). } \\
\text { Posição da lâmpada: dentro do tubo de } \\
\text { quartzo. } \\
\text { Vazão: } 3 \text { a } 12 \mathrm{~L} \mathrm{~h}^{-1} \text {. } \\
{\left[\mathrm{H}_{2} \mathrm{O}_{2}\right]_{0}: 50 \text { a } 200 \mathrm{mg} \mathrm{L}^{-1} \text { (adicionado à }} \\
\text { solução contaminada). } \\
\text { Temperatura: } 25^{\circ} \mathrm{C} \text { (reator encamisado) } \\
\text { pH: } 3 \text {. }\end{array}$ & $\begin{array}{l}\text { Modelo fenomenológico } \\
\text { proposto se adequa aos } \\
\text { resultados experimentais. } \\
\text { Condições ótimas de } \\
\text { operação: }\left[\mathrm{H}_{2} \mathrm{O}_{2}\right]_{\circ}=150 \mathrm{mg} \mathrm{L} \\
1, \mathrm{I}=82 \mathrm{~W} / \mathrm{m}^{2} \text { e maiores } \\
\text { tempos de retenção resultam } \\
\text { em remoção de } \sim 90 \% \text {. }\end{array}$ \\
\hline $\begin{array}{l}\text { Daneshvar } \\
\text { et al. } \\
\text { (2005) }\end{array}$ & $\begin{array}{l}\text { Pigmento } \\
\text { monoazo } \\
\text { aniônico } \\
\text { "Acid Red } \\
27 " \text { (AR27). } \\
\mathrm{C}_{0}=150 \mathrm{mg} / \mathrm{L}\end{array}$ & $\begin{array}{l}\text { Descrição do reator: Quatro fotoreatores } \\
\text { tubulares de quartzo em série. } \\
\text { Volume útil: } 1,6 \mathrm{~L} \text {. } \\
\text { Fonte de radiação: Quatro lâmpadas a } \\
\text { vapor de mercúrio em baixa pressão com } \\
\text { emissão em } 254 \mathrm{~nm} \text { (30W, UV-C). } \\
\text { Posição da lâmpada: em frente ao tubo } \\
\text { de quartzo distante } 5 \mathrm{~cm} \text {. Intensidade de } \\
\text { luz ( } \mathrm{I}_{0}=14 \text { a } 59 \mathrm{~W} / \mathrm{m}^{2} \text { ) varia com esta } \\
\text { distância. } \\
\text { Vazão: } 1 \text { a } 3 \mathrm{~L} \mathrm{~h}^{-1} \text {. } \\
{\left[\mathrm{H}_{2} \mathrm{O}_{2}\right]_{0}: 150 \text { a } 1300 \mathrm{mg} \mathrm{L}^{-1} \text { (adicionado à }} \\
\text { solução contaminada). } \\
\text { Temperatura: não reportada. } \\
\text { pH: não reportado. }\end{array}$ & $\begin{array}{l}\text { Condição ótima de operação: } \\
{\left[\mathrm{H}_{2} \mathrm{O}_{2}\right]_{0}=650 \mathrm{mg} \mathrm{L}^{-1}, \mathrm{I}_{0}=59} \\
\mathrm{~W} / \mathrm{m}^{2}, \mathrm{Vazão}=1 \mathrm{~L} \mathrm{~h}^{-1}, \\
\text { resultando em completa } \\
\text { remoção de cor e de AR27 }\end{array}$ \\
\hline
\end{tabular}




\section{MATERIAIS E MÉTODOS}

\subsection{Equipamento}

\subsubsection{Sistema Batelada}

Os experimentos em sistema fotoquímico batelada foram realizados para avaliar o efeito da potência da lâmpada $(\mathrm{P})$, da concentração de $\mathrm{H}_{2} \mathrm{O}_{2}\left(\left[\mathrm{H}_{2} \mathrm{O}_{2}\right]_{0}\right)$ no sistema, da temperatura $(\mathrm{T})$ e da concentração inicial de carbono orgânico (COT。) sobre a taxa de degradação de compostos orgânicos. O esquema e a foto do aparato experimental estão apresentados na Figura 6 e Figura 7. Esse sistema é composto por um reator fotoquímico em vidro borossilicato com volume útil de $1 \mathrm{~L}$, anular de fluxo ascendente, ao qual se adapta um poço coaxial encamisado em quartzo, para inserção de uma lâmpada a vapor de mercúrio de média pressão (Philips HPLN de 400, 250, 125 ou 80 W). O reator fotoquímico é conectado a um tanque de mistura encamisado, volume útil de $1 \mathrm{~L}$, com uma saída para uma bomba centrífuga, a qual recircula o efluente no sistema. A vazão de recirculação do efluente foi constante em todos os experimentos e igual a 2,5 L/min. A temperatura da solução foi controlada por um banho termostático (TECNAL, TE-184). Um termopar cromel-alumel de haste flexível, conectado a um indicador digital de temperatura (Oakton, 90080-00), foi utilizado para medir a temperatura no interior do tanque. $O$ efluente no interior do tanque é homogeneizado constantemente por um agitador mecânico (Ética 103). No início e durante os ensaios, o pH da solução não foi ajustado. A medida do pH (QUIMIS, Q-400BC) da solução e a coleta de amostras foram realizadas no tanque de mistura em diferentes tempos de reação. Em grande parte dos ensaios, exceto quando citado, peróxido de hidrogênio foi adicionado ao sistema numa dosagem única no início do experimento com o auxílio de uma pipeta e sua concentração inicial $\left(\left[\mathrm{H}_{2} \mathrm{O}_{2}\right]_{0}\right)$ é definida em relação ao volume total de solução aquosa no sistema, mantida em $2 \mathrm{~L}$. O reator fotoquímico é posto dentro de uma caixa metálica para proteção em relação à radiação ultravioleta. 


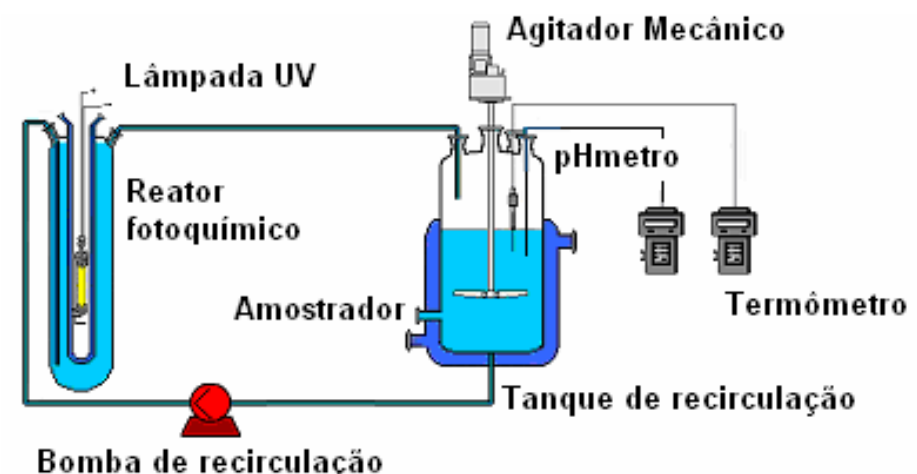

Figura 6 - Esquema do reator fotoquímico em escala de bancada.

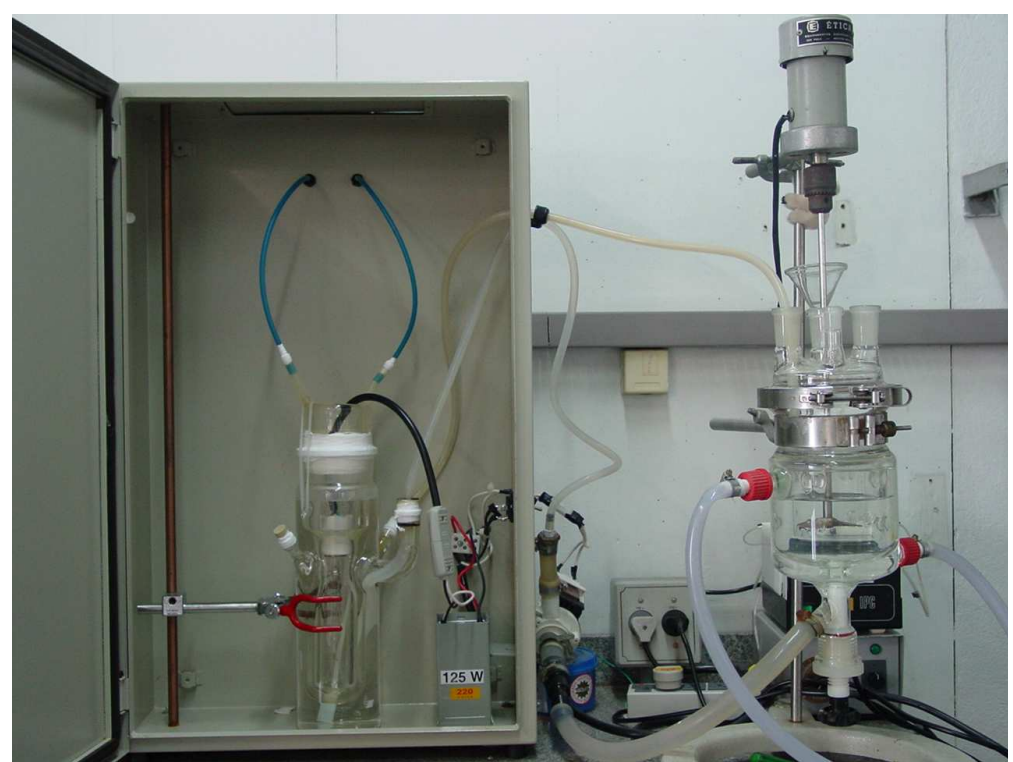

Figura 7 - Foto do reator fotoquímico em escala de bancada

O procedimento experimental adotado para os ensaios em sistema batelada é apresentado no item 3.3 Procedimento Experimental. A Figura 8 apresenta 0 espectro de transmissão do poço de quartzo utilizado nos ensaios.

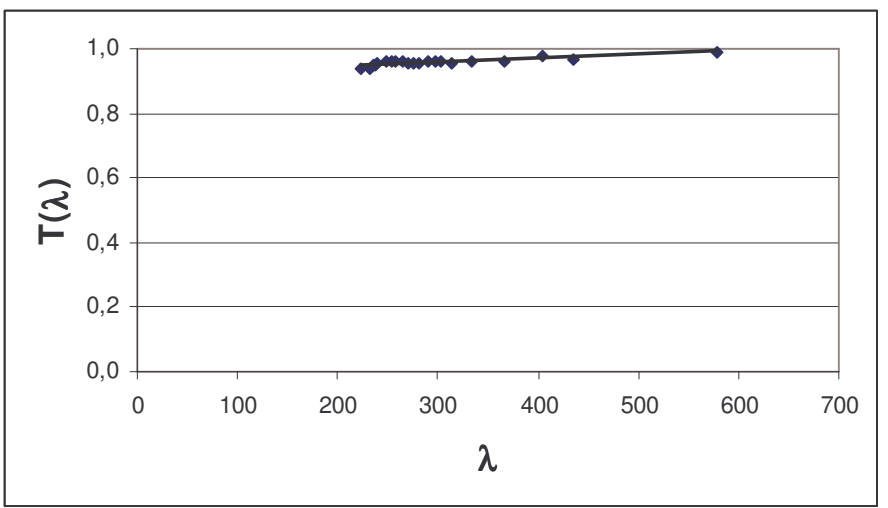

Figura 8 - Espectro de transmissão do poço de quartzo encamisado do reator fotoquímico em sistema batelada. 


\subsubsection{Sistema Contínuo}

O reator fotoquímico contínuo foi concebido como uma série de 4 compartimentos, cada um dos quais com volume adequado para se obterem relações entre volume e potência nominal da lâmpada compatíveis com as condições mais adequadas, com base nos resultados dos estudos com sistema em batelada. O reator, construído em aço inox 304, possui 3 chicanas internas que dividem o reator em quatro partes. Em cada uma das quatro partes se encaixa um poço de quartzo onde se pode posicionar uma lâmpada a vapor de mercúrio de media pressão (80, 125, 250 e 400 W, HPLN Philips), resultando numa configuração máxima de até 4 lâmpadas de iguais ou de variadas potências. O volume útil do reator é de 13,75 $\pm 0,03$ litros. A Figura 9 mostra o desenho do reator. $O$ escoamento no interior do reator dá-se de forma alternada ao longo do reator, ora ascendente, ora descendente devido à presença das chicanas (Figura 10).

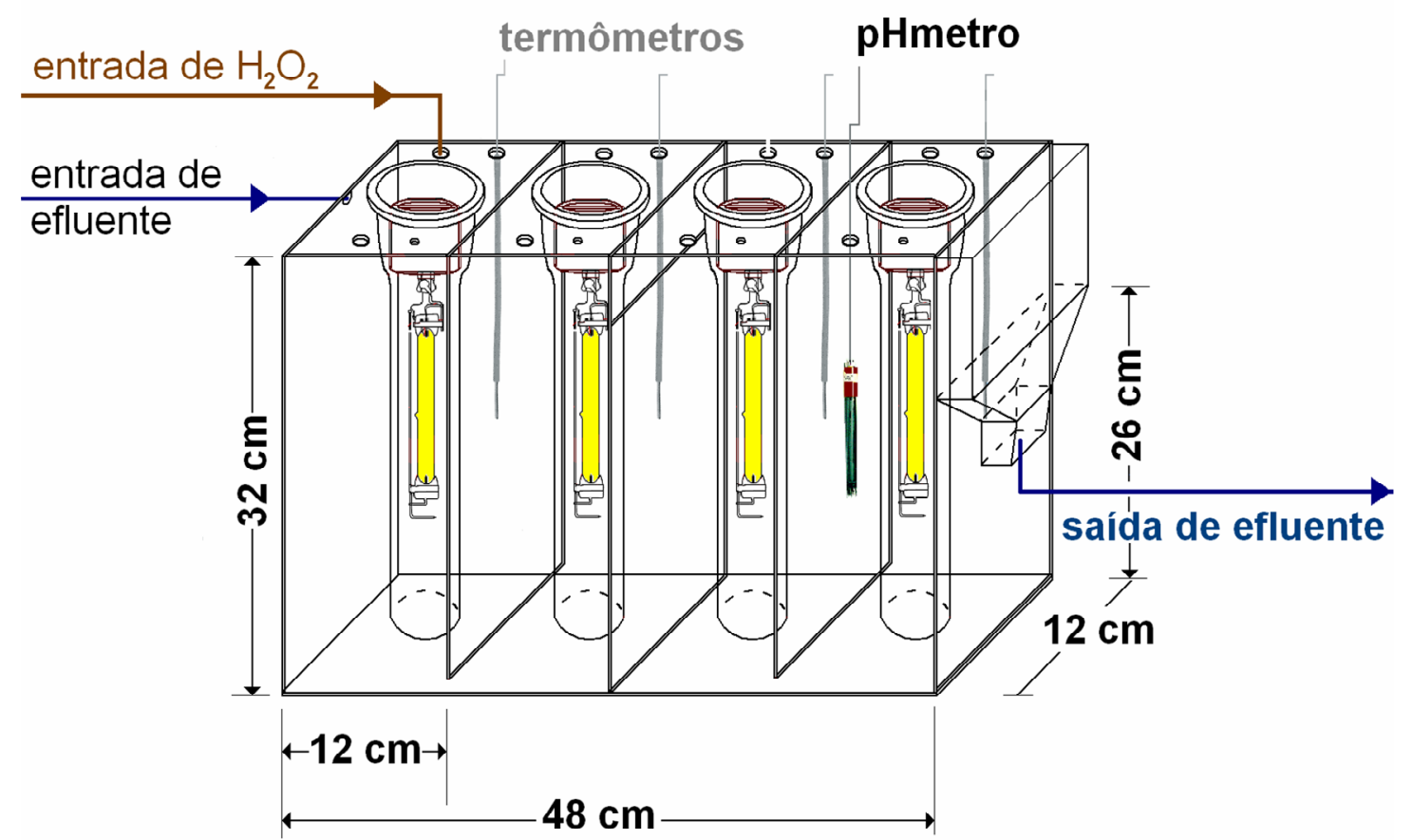

Figura 9 - Desenho esquemático do reator fotoquímico contínuo.

Para operação do reator multilâmpadas, o sistema esquematizado pela Figura 11 foi montado. Esse sistema é composto por dois tanques de $50 \mathrm{~L}$, duas bombas centrífugas, tubulações rígidas de PVC de diâmetro nominal de $1 / 2$ polegada, válvulas e conexões de PVC. O sistema construído permite a operação contínua ou em batelada, conforme apresentado a seguir. 


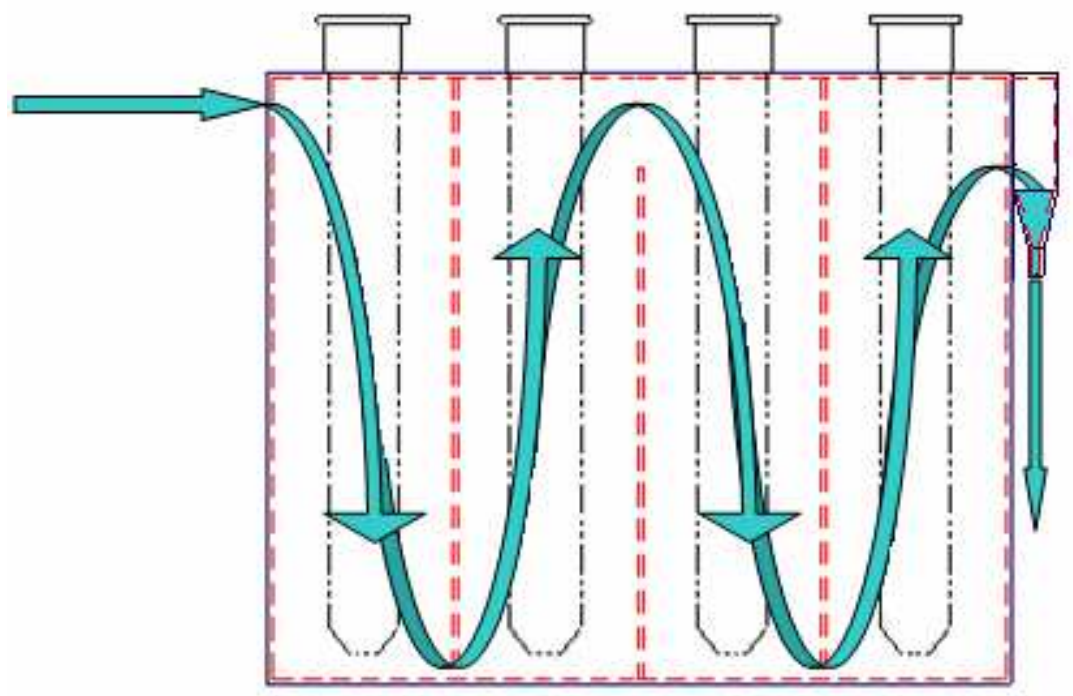

Figura 10 - Desenho esquemático do escoamento no interior do reator fotoquímico contínuo.

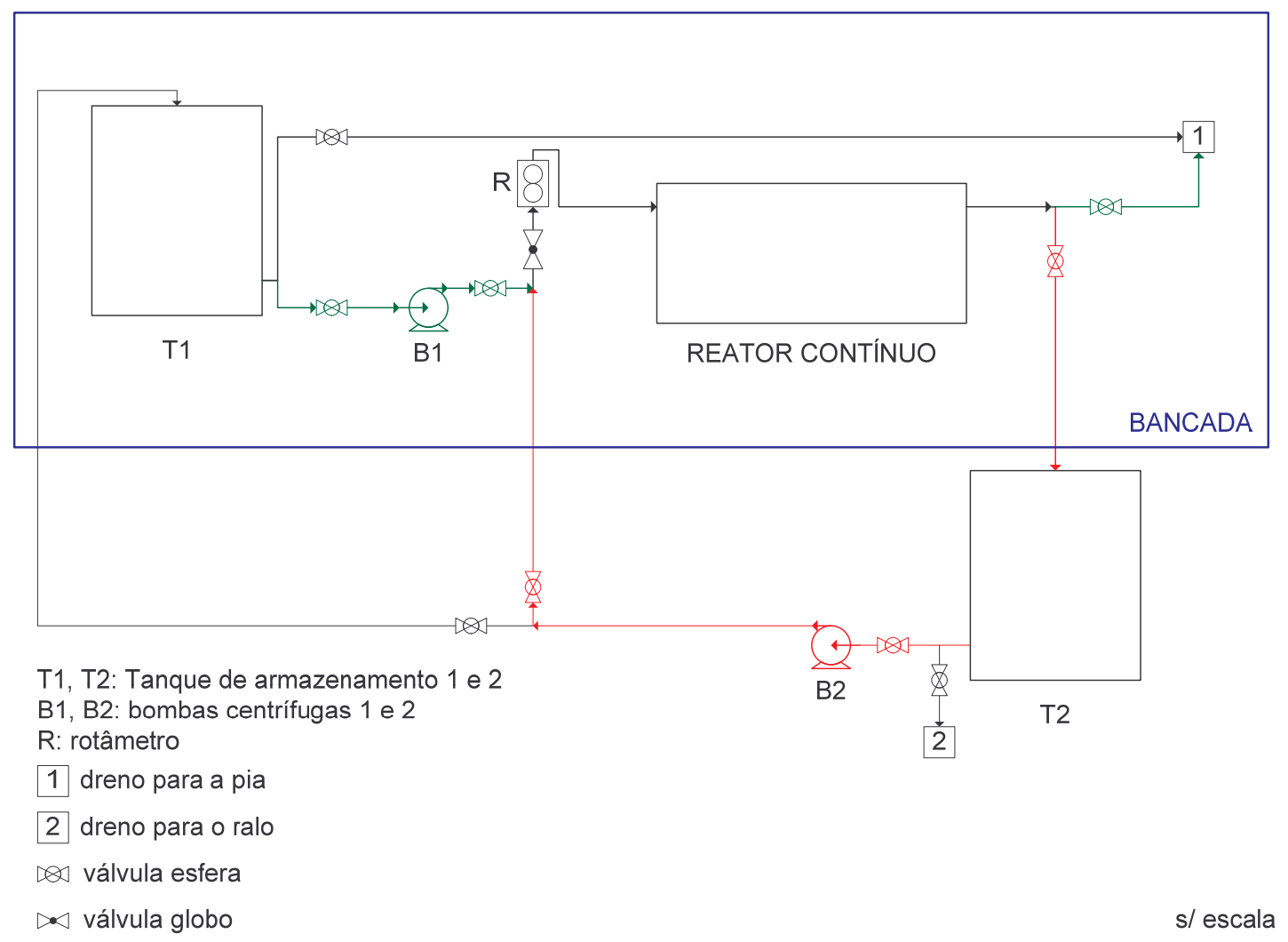

Figura 11 - Sistema do reator multilâmpadas. O reator pode ser operado de forma contínua (linha verde) ou em batelada (linha vermelha) 


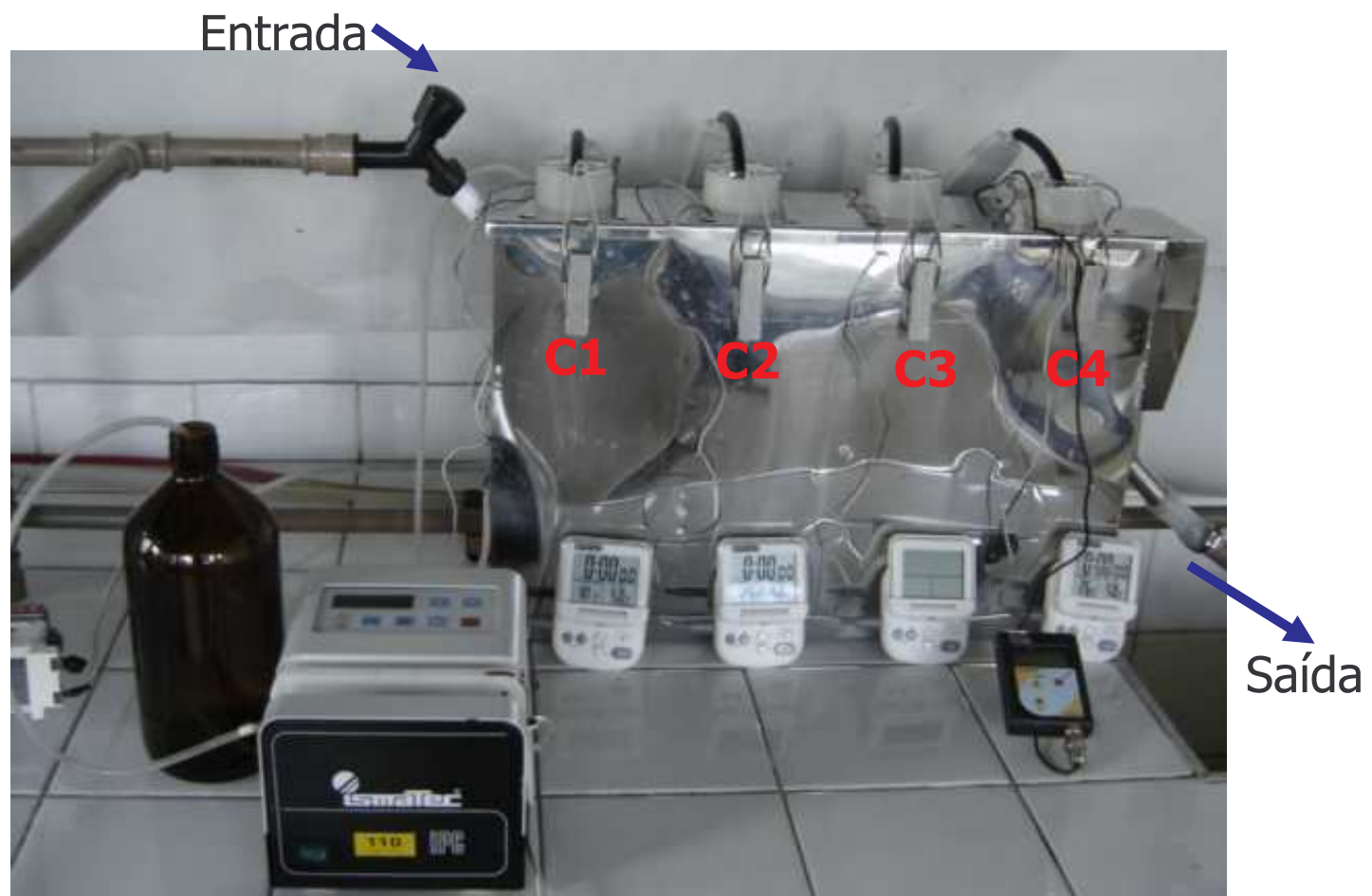

Figura 12 - Foto do reator contínuo fotoquímico

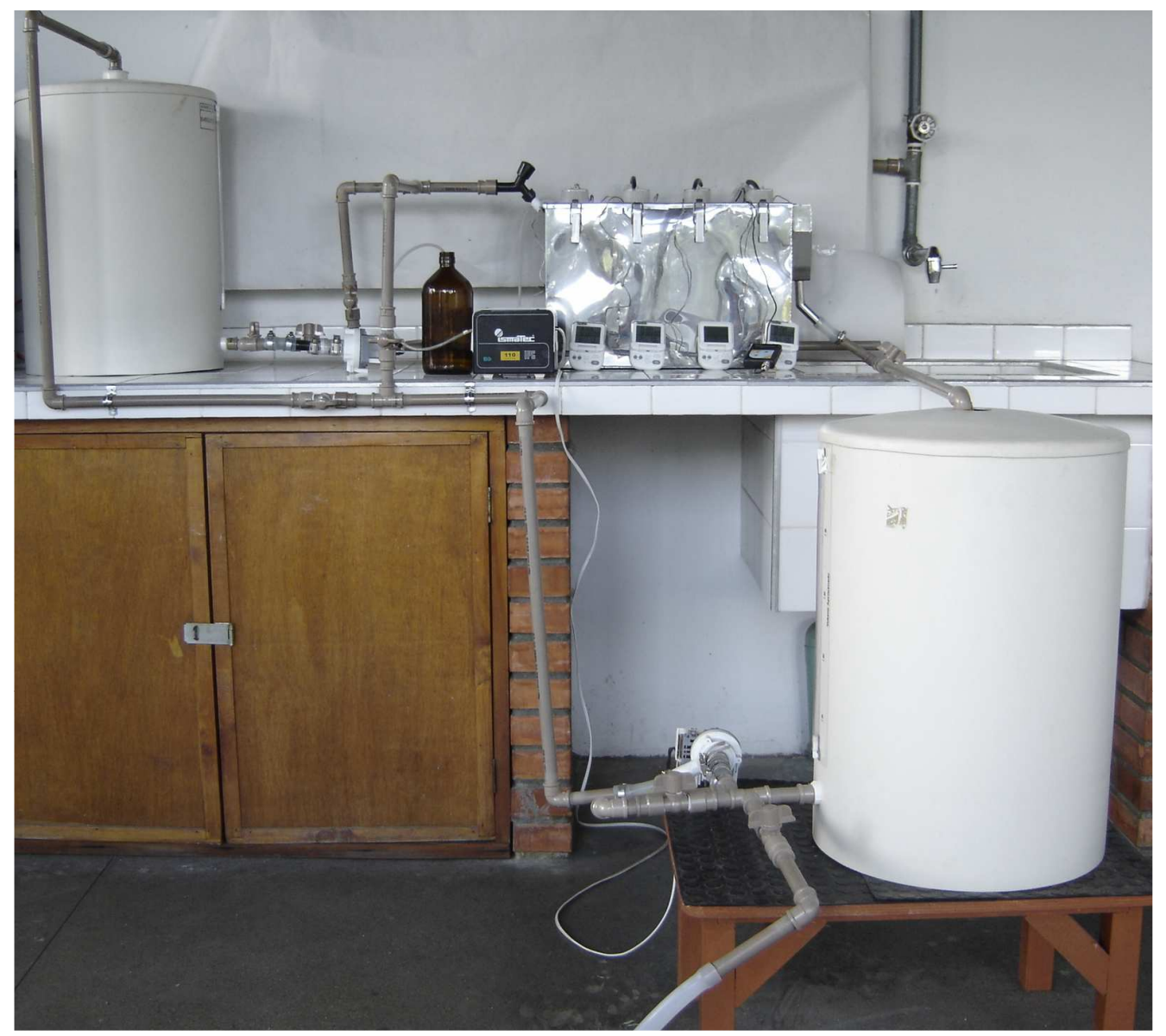

Figura 13 - Foto do sistema do reator contínuo fotoquímico

Durante os experimentos, a temperatura em cada um dos compartimentos foi monitorada através de termômetros digitais acoplados a termopares (Oakton, 90080- 
00). O monitoramento do $\mathrm{pH}$ foi feito utilizando um pHmetro (Quimis, Q-400BC), posicionado no último compartimento (C4). As amostras foram retiradas com auxílio de seringas acopladas a mangueiras flexíveis inseridas no interior dos compartimentos C1, C2 e C3 e diretamente na saída do reator após o compartimento $\mathrm{C} 4$.

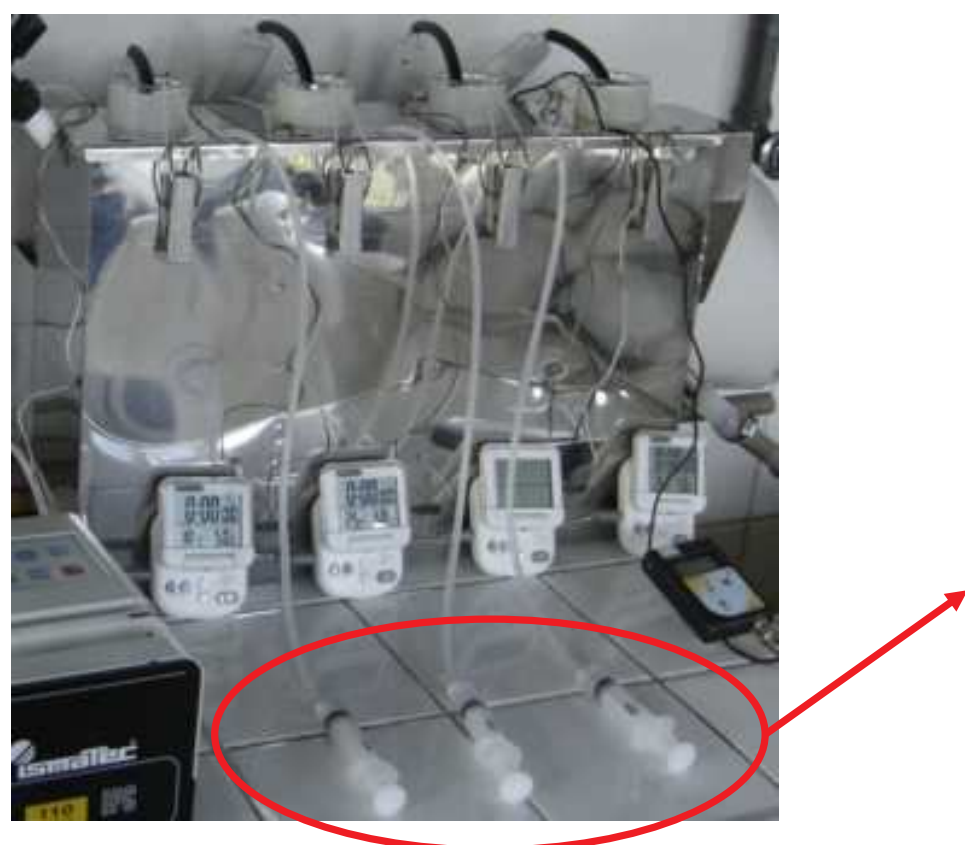

Sistema de amostragem: seringas acopladas a mangueiras flexiveis

Figura 14 - Foto do reator contínuo fotoquímico mostrando em detalhe o sistema de amostragem.

\subsection{Materiais}

Em todos os experimentos utilizaram-se efluentes da indústria petroquímica Suzano Petroquímica, coletados em quatros diferentes pontos do processo (Figura 15), com diferentes concentrações de poluentes.

Antes de todos os experimentos as amostras foram filtradas a fim de remover os sólidos suspensos. Nos ensaios descontínuos (2 litros de efluente por experimento), os efluentes foram filtrados utilizando filtro lento $\mathrm{n}^{\circ} 1542$ CAAL, abertura de $2 \mu \mathrm{m}$. Já nos ensaios contínuos (55 litros de efluente por experimento), o efluente foi filtrado na própria planta industrial, onde foi implementado filtro do tipo semi-bag de 200 mesh $(=74 \mu \mathrm{m})$ na saída do processo P1. As características dos efluentes industriais investigados estão apresentadas na Tabela 11, que mostra as faixas de valores de COT, pH e DQO. 


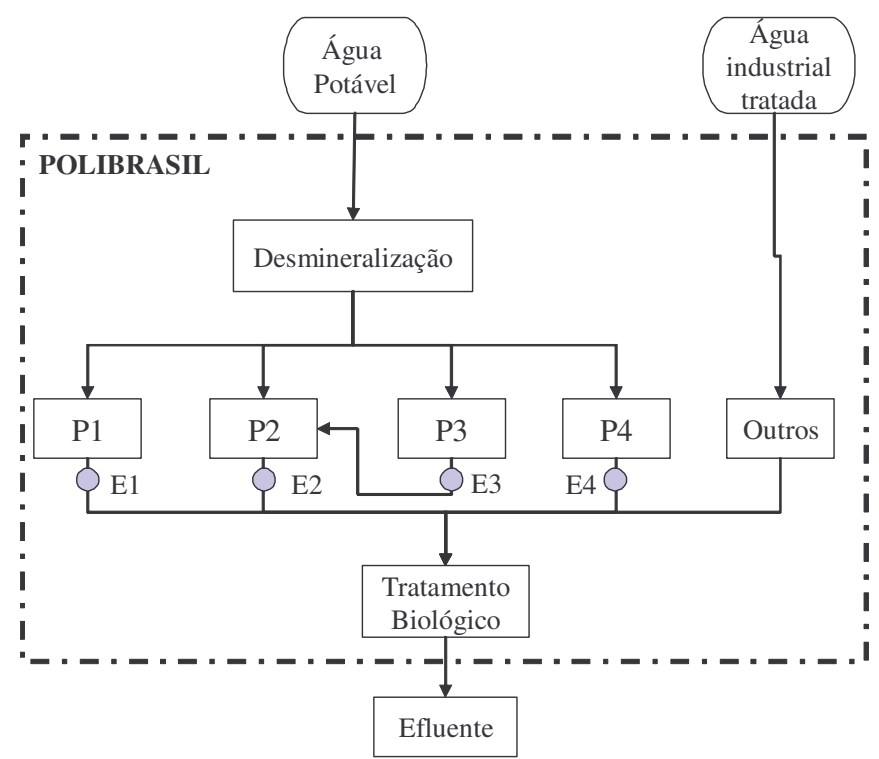

Figura 15 - Pontos de coleta dos efluentes investigados, indicados pelos círculos.

Tabela 11 - Caracterização dos efluentes estudados

\begin{tabular}{|c|c|c|c|c|}
\hline Efluente & E1 & E2 & E3 & E4 \\
\hline $\mathrm{COT}^{\mathrm{a}}\left(\mathrm{mgC} \mathrm{L}^{-1}\right)$ & $3,0-8,0$ & $3,0-10,0$ & $4,0-16,0$ & $278-337$ \\
\hline $\mathrm{pH}^{\mathrm{a}}$ & $2,8-6,6$ & $5,9-7,6$ & $4,5-7,3$ & $6,3-7,5$ \\
\hline $\mathrm{DQO}^{\mathrm{a}}\left(\mathrm{mgO}_{2} \mathrm{~L}^{-1}\right)$ & $26-35$ & $25-102$ & 82-105 & 1218-1305 \\
\hline $\mathrm{DBO}^{\mathrm{a}}\left(\mathrm{mgO}_{2} \mathrm{~L}^{-1}\right)$ & $10-14$ & * & * & * \\
\hline SST (mg L-1) & $2-4$ & * & * & * \\
\hline$\overline{F e^{a}\left(m g ~ L^{-1}\right)}$ & $0,0140-0,0811$ & * & * & * \\
\hline $\mathrm{Mn}^{\mathrm{a}}\left(\mathrm{mg} \mathrm{L}^{-1}\right)$ & $<0,003$ & * & * & * \\
\hline $\operatorname{Vazão}\left(m^{3} / h\right)^{b, c}$ & $2,0-2,5$ & $2,0-2,5$ & $2,0-2,5^{d}$ & 0,024 \\
\hline
\end{tabular}

A variação desses parâmetros é causada por flutuações no próprio processo produtivo da indústria, como conseqüência da demanda de mercado dos três tipos de polipropileno fabricados, mencionados no item 2.2.2. Os tipos de polipropileno englobam Homopolímeros, Copolímeros Randômicos e Copolímeros Heterofásicos. Nesta tabela, também são apresentadas os valores das vazões desses efluentes gerados na planta petroquímica.

A pequena quantidade de ferro contida no efluente (máximo valor $=0,0811$ $\mathrm{mg} \mathrm{L}^{-1}=0,0014 \mathrm{mM}$ ) não provoca efeitos fotocatalíticos significativos, pois a quantidade de ferro geralmente adicionada nos processos foto-Fenton é, em geral, superior a 0,05 mM (VENKATADRI; PETERS, 1993).

A partir da análise dos valores de COT。 (Carbono Orgânico Total inicial) referentes ao mesmo período de coleta, foi verificada uma tendência de redução em função do tempo de armazenamento (Figura 16), o que se deve provavelmente à 
coagulação de parte do material dissolvido seguida de sua remoção na etapa de filtração.
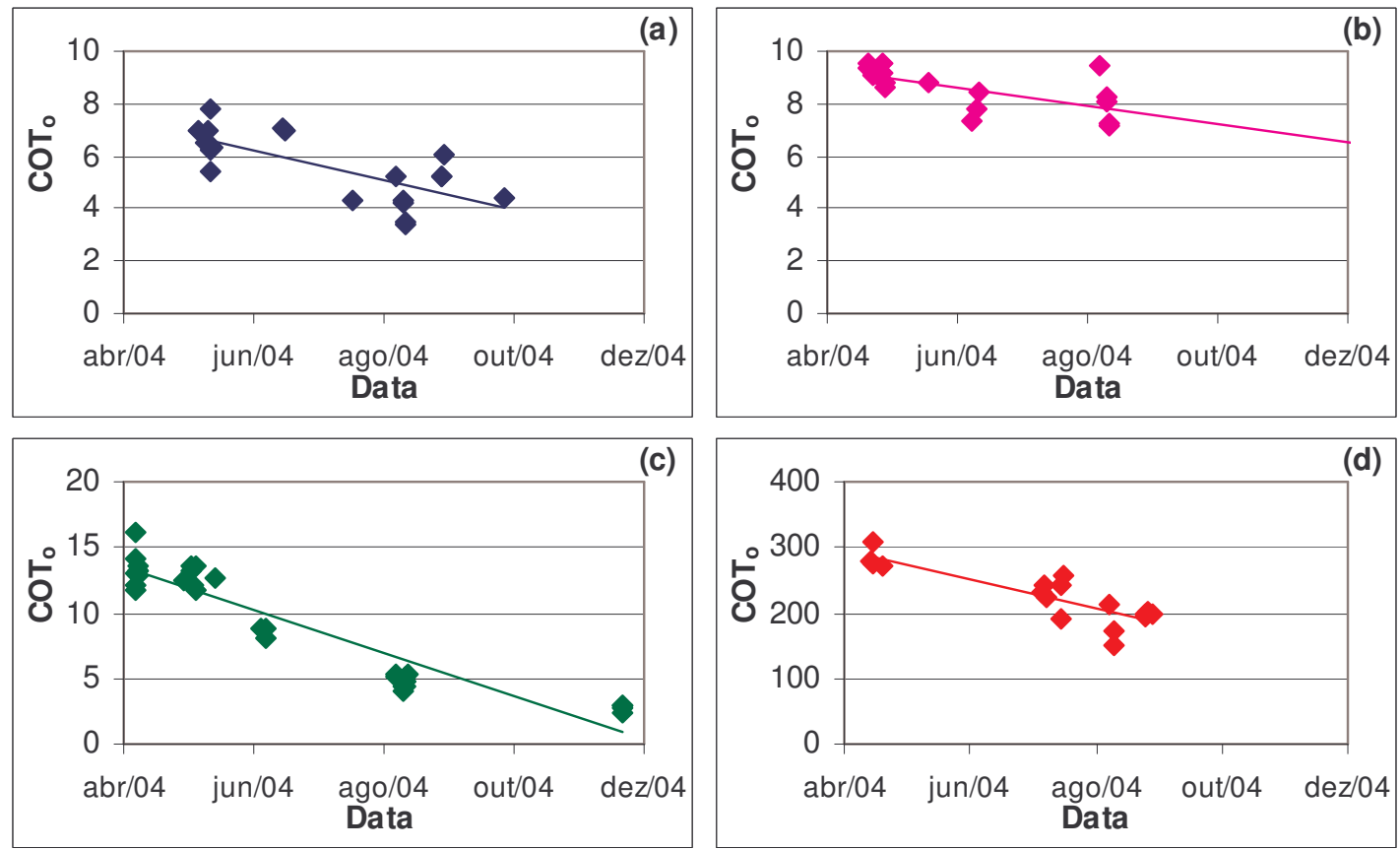

Figura 16 - Valores de COT。 (carbono orgânico total inicial) versus tempo de armazenamento dos efluentes coletados em abril/2004, COT。 medido após filtração. (a) efluente E1, (b) efluente E2, (c) efluente E3 e (d) efluente E4.

Além dos efluentes descritos, foi utilizado peróxido de hidrogênio 30-35\% $(\mathrm{m} / \mathrm{m})$ (Nuclear, Reatec e CAAL) como reagente fonte de radicais hidroxila.

Para os ensaios de distribuição do tempo de residência do reator contínuo, azul de metileno (cloreto de tetrametiltionina - $\mathrm{C}_{16} \mathrm{H}_{18} \mathrm{~N}_{3} \mathrm{SCl}$ ) a $13,6 \%$ (em massa) foi utilizado como traçador.

\subsection{Procedimento Experimental}

\subsubsection{Ensaios de fotodegradação em sistemas descontínuo e contínuo}

Os experimentos em sistema descontínuo foram realizados com um volume total de 2 litros de solução. As amostras foram retiradas da mangueira que envia 0 efluente do reator para o tanque de recirculação. 
Os experimentos em sistema contínuo foram realizados com um volume total variando de 55 litros de efluente no sistema em cada ensaio. As amostras foram retiradas com auxílio de seringas acopladas a mangueiras flexíveis inseridas no interior dos compartimentos C1, C2 e C3 e diretamente na saída do reator após o compartimento C4.

O procedimento experimental para ambos os sistemas foi realizado da forma descrita a seguir.

A massa total de peróxido de hidrogênio necessária para atingir a dose de $\mathrm{H}_{2} \mathrm{O}_{2}$ definida para o experimento foi calculada, conforme item 3.5 (Cálculo da quantidade de $\mathrm{H}_{2} \mathrm{O}_{2}$ ). Para dosagem de $\mathrm{H}_{2} \mathrm{O}_{2}$ via bomba peristáltica ou em diversos intervalos ao longo do ensaio, esta massa foi diluída em um volume adequado de água destilada.

As lâmpadas de potências (80, 125, 250 ou 400 W) definidas para o ensaio foram posicionadas dentro dos poços de quartzo e conectadas às respectivas fontes, totalizando 1 lâmpada para o sistema batelada e 4 lâmpadas para o sistema contínuo.

O efluente industrial foi adicionado ao sistema batelada (2 litros) ou contínuo (de 55 litros). Nos ensaios em sistema contínuo antes de iniciar o experimento, o efluente foi recirculado do reator para os tanques e vice-versa para promover a mistura do efluente.

Um termopar e um pHmetro foram posicionados no tanque de mistura do sistema batelada. Um termopar foi posicionado em cada um dos quatros compartimentos do sistema contínuo e um pHmetro foi colocado no compartimento final C4.

Deste ponto em diante, a seguinte seqüência foi ser adotada para os ensaios em sistema batelada: (1) o agitador mecânico, a bomba de recirculação e o banho termostático, ajustado para a temperatura estabelecida para o ensaio, foram ligados; (2) quando a temperatura atingiu o valor desejado, a primeira amostra $(7 \mathrm{~mL})$ foi retirada para a análise de COT e os valores de temperatura e $\mathrm{pH}$ foram anotados; (3) a água de resfriamento da lâmpada foi acionada; (4) a caixa do reator foi fechada.

Já para os ensaios em sistema contínuo, o procedimento foi: (1) as bombas B1 e B2 foram ligadas para fazer recircular o efluente dentro do sistema; (2) as vazões de efluente (bomba B1) e de peróxido de hidrogênio (bomba peristáltica) 
foram ajustadas, de acordo com os valores definidos para o ensaio; (3) em cada compartimento foi retirada uma amostra inicial $(7 \mathrm{~mL})$ para a análise de COT e os valores de temperatura e $\mathrm{pH}$ foram anotados.

Para ambos sistemas, as lâmpadas foram ligadas e a estabilização do nível de luminosidade foi aguardada por cerca de 2 minutos. O ensaio foi iniciado com a adição de peróxido de hidrogênio simultaneamente ao acionamento do cronômetro.

As demais amostras foram removidas para leitura do COT nos tempos estabelecidos e os valores de temperatura e $\mathrm{pH}$ foram anotados. Para cada amostra foram retirados $7 \mathrm{~mL}$ de efluente.

Ao longo do ensaio no sistema contínuo o valor da vazão de efluente foi verificado e, sendo necessário, novos ajustes foram feitos.

\subsubsection{Ensaios de Distribuição de tempos de residência (DTR)}

Para caracterização do sistema contínuo, foi necessário fazer a medição da distribuição de tempos de residência (DTR). A avaliação é feita com o auxílio da técnica de estímulo e resposta, que consiste na injeção de uma substância inerte chamada traçador na entrada do reator no tempo $t=0$ e pela medida de concentração deste traçador na saída do reator em função do tempo. O traçador de concentração conhecida deve ser facilmente detectável e não participar de nenhum processo físico ou químico que transforme a hidrodinâmica do fluido (DANTAS; MELO; NETO, 2000). Os dois mais usuais métodos de injeção são: perturbação em pulso (pulse input) e perturbação em degrau (step input) (FOGLER, 1999).

$\mathrm{Na}$ perturbação em pulso, uma quantidade $\mathrm{N}_{0}$ de traçador é injetada na entrada do reator num intervalo de tempo o menor possível. Na perturbação em degrau, o traçador é alimentado ao sistema a uma taxa constante num intervalo de tempo pré-estabelecido. As características relativas aos métodos de injeção estão apresentadas na Tabela 12.

Devido às características mencionadas, adotou-se neste trabalho o método de injeção pulso para o estudo da distribuição dos tempos de residência nos reatores contínuos. 
Tabela 12 - Quadro comparativo de métodos de injeção

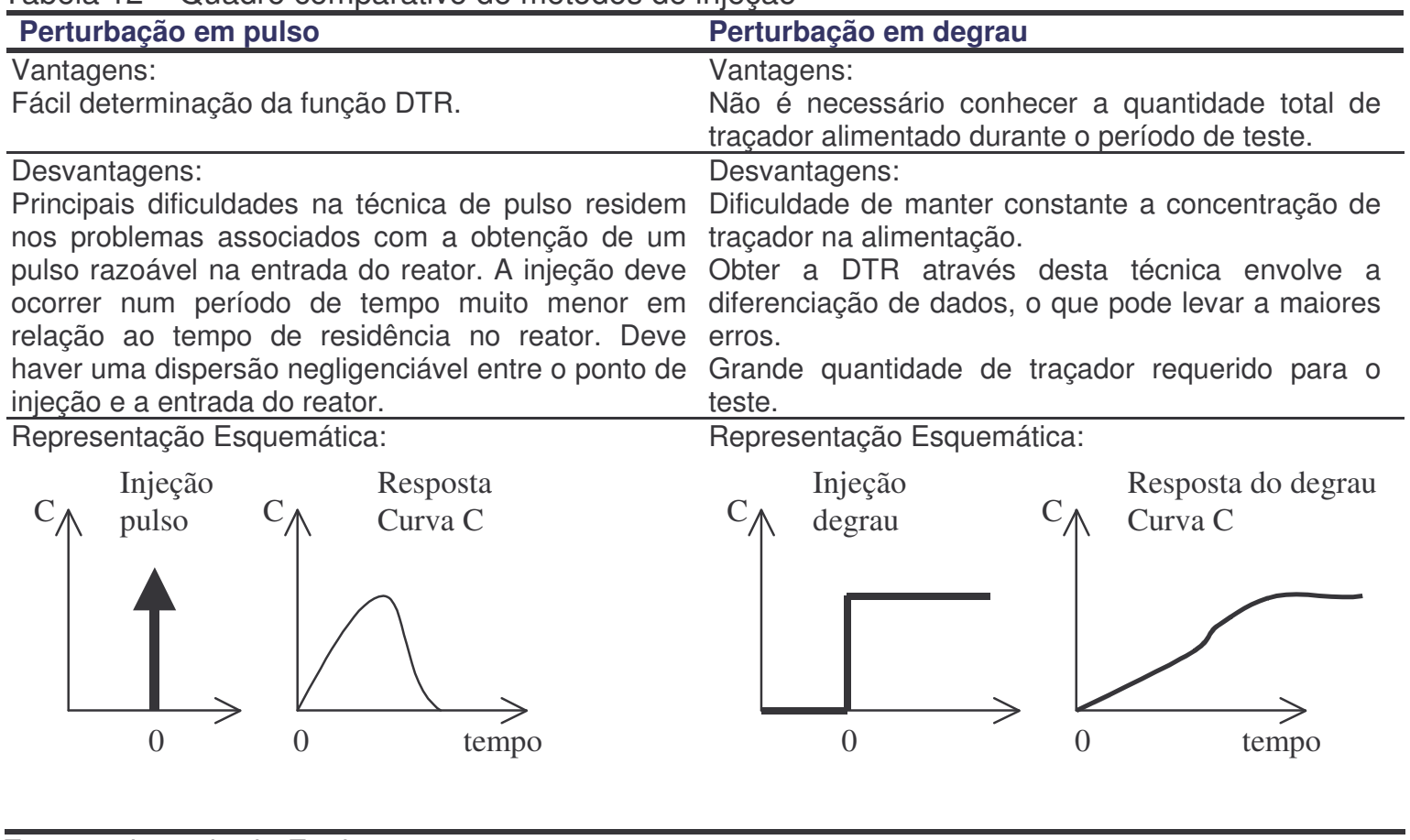

Fonte: adaptado de Fogler, 2000.

A DTR do reator fotoquímico contínuo foi determinada experimentalmente pela injeção pulso de uma solução de azul de metileno (13\% em massa) na entrada do reator no tempo $t=0$ e pela medida de concentração deste traçador na saída do reator em função do tempo. O volume de traçador adicionado com auxílio de uma pipeta automática (GILSON, P1000) foi de 1mL. A concentração máxima esperada de azul de metileno na saída do reator é de aproximadamente 0,03 mM, considerando mistura perfeita e instantânea. Os ensaios foram conduzidos em vazões variadas entre 10 e 90 L/h. Para simular o fluxo de efluente no reator, água da rede foi usada durante os ensaios em vez do efluente.

Para a elaboração da curva de calibração no espectrofotômetro, preparou-se uma solução de azul de metileno de concentração 0,175 mM. A partir dessa solução, foram feitas 12 diluições com o objetivo de preparar as soluções padrões da curva de calibração do traçador. As amostras foram analisadas em um espectrofotômetro de Ultra Violeta - Visível (Varian CARY 50) pela leitura das absorbâncias nos comprimentos de onda entre 820 e $190 \mathrm{~nm}$.

A partir dos espectros obtidos observou-se que o azul de metileno absorve fortemente luz no comprimento de onda de $665 \mathrm{~nm}$ e que uma maior ou menor intensidade de absorção neste comprimento de onda depende da concentração.

A Figura 17 apresenta a reta de calibração obtida. 
A partir da distribuição dos pontos no gráfico, determinou-se a equação de regressão linear através do método dos mínimos quadrados (Eq. 19).

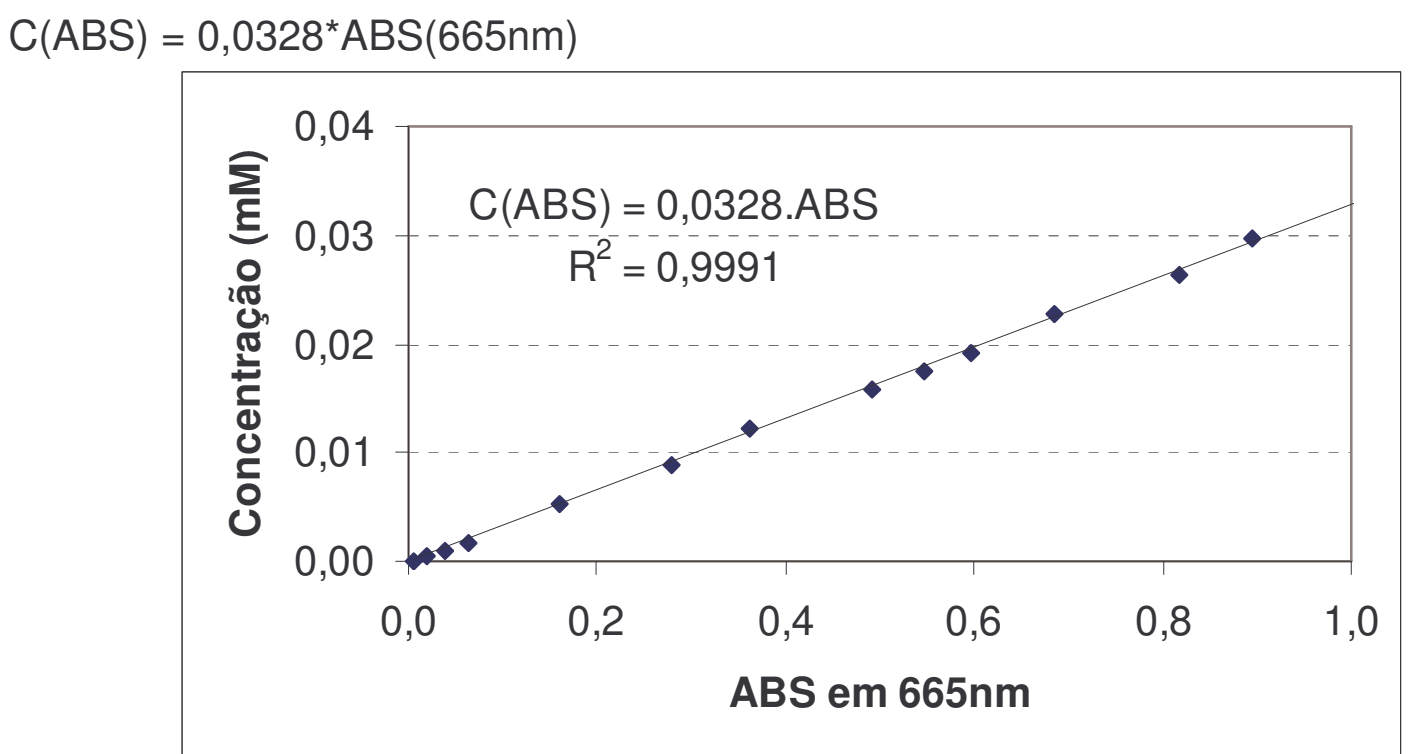

Figura 17 - Curva de calibração do traçador (azul de metileno).

\subsection{Análises}

$\mathrm{O}$ residual de $\mathrm{H}_{2} \mathrm{O}_{2}$ presente nas amostras de efluente interfere na análise de DQO, cujo valor tende a aumentar, visto que uma parcela de DQO é produzida pelo $\mathrm{H}_{2} \mathrm{O}_{2}$ que provoca oxidação dos compostos contidos na amostra (JUANG; TSENG; YANG, 1997). Devido a este fato, a DQO ao longo dos experimentos não foi determinada. A análise de DQO foi feita apenas em algumas amostras iniciais, ou seja, antes da adição de peróxido.

As amostras de efluente coletadas em diferentes tempos de reação foram imediatamente analisadas quanto ao seu teor de carbono orgânico total em um analisador de TOC (Shimadzu, TOC-5000A). O aparelho mede a quantidade total de carbono (TC) e a quantidade de carbono inorgânico (IC) na solução. A diferença dos dois valores é a quantidade total de carbono orgânico (COT). A medição do TC se dá pela combustão completa da amostra em um forno a $680^{\circ} \mathrm{C}$. O produto de combustão $\left(\mathrm{CO}_{2}\right)$ é levado pelo gás de arraste até um detector infravermelho (NDIR) onde $\mathrm{o} \mathrm{CO}_{2}$ é detectado. $\mathrm{O}$ carbono inorgânico inclui todos os $\mathrm{CO}_{3}{ }^{2-}, \mathrm{HCO}_{3}{ }^{-}$e $\mathrm{CO}_{2}$ contidos em uma amostra. Em um meio ácido, todo o IC é purgado da solução por um gás de arraste na forma de $\mathrm{CO}_{2}$, e este é detectado pelo NDIR. Para a análise 
de COT das amostras foi feita uma calibração com os pontos 0, 50, 100 e 200 mgC $\mathrm{L}^{-1}$, aos quais foi ajustada uma reta que passa pela origem. $\mathrm{O}$ equipamento de COT foi calibrado com a solução de biftalato de potássio como padrão de calibração.

Teores de Fe e Mn de amostras do efluente E1 foram determinados via ICP. AES (Espectrometria de emissão atômica por plasma indutivamente acoplado) pela Central Analítica do Instituto de Química da USP.

As amostras do ensaio de DTR foram levadas ao espectrofotômetro, obtendose a absorbância em função do comprimento de onda para cada amostra.

\subsection{Cálculo da quantidade de $\mathrm{H}_{2} \mathrm{O}_{2}$}

A quantidade e concentração de $\mathrm{H}_{2} \mathrm{O}_{2}$ utilizada nos experimentos foi calculada de acordo com a quantidade mássica proporcional à massa de carbono orgânico total presente em um determinado volume de efluente, definida como sendo a razão $\alpha=\frac{C_{\mathrm{H}_{2} \mathrm{O}_{2}}}{\mathrm{COT}_{o}}$. Por se tratar de um efluente real e estando sujeito às variabilidades do processo industrial, foi necessário o monitoramento de COT dos efluentes em cada remessa enviada pela indústria e também antes de cada ensaio. Portanto, definindo-se a razão $\alpha$ e conhecendo-se os valores de COT $_{0}$ foi possível calcular a quantidade de $\mathrm{H}_{2} \mathrm{O}_{2}$ empregada em cada ensaio.

$$
\begin{aligned}
& V_{\mathrm{H}_{2} \mathrm{O}_{2}}=\frac{0,1 \cdot \alpha \cdot C O T_{0} \cdot V_{\text {efluente }}}{\rho_{\mathrm{H}_{2} \mathrm{O}_{2}} \cdot \text { teOr }_{\mathrm{H}_{2} \mathrm{O}_{2}}} \\
& m_{\mathrm{H}_{2} \mathrm{O}_{2}}=\alpha \cdot \mathrm{COT}_{0} \cdot V_{\text {efluente }}
\end{aligned}
$$

em que:

$V_{\mathrm{H}_{2} \mathrm{O}_{2}}$ : volume de peróxido de hidrogênio $(\mathrm{mL})$

$m_{\mathrm{H}_{2} \mathrm{O}_{2}}$ : massa de peróxido de hidrogênio $(\mathrm{mg})$

$\mathrm{C}_{\mathrm{H}_{2} \mathrm{O}_{2}}$ : concentração de peróxido de hidrogênio ( $\mathrm{mg} \mathrm{L}^{-1}$ )

0,1 = fator de conversão (de g para mg e \% para valor fracionário)

$\alpha=\frac{C_{\mathrm{H}_{2} \mathrm{O}_{2}}}{C O T_{o}}$

$\mathrm{COT}_{0}$ : Carbono orgânico total no início do experimento $\left(\mathrm{mgC} \mathrm{L}^{-1}\right)$ teor $_{\mathrm{H}_{2} \mathrm{O}_{2}}$ : teor mássico $(\mathrm{m} / \mathrm{m})$ da solução de peróxido de hidrogênio $(\%)$

$\rho_{\mathrm{H}_{2} \mathrm{O}_{2}}$ : densidade da solução de peróxido de hidrogênio $\left(\mathrm{g} / \mathrm{cm}^{3}\right)$ 
$V_{\text {efluente }}$ : volume de efluente utilizado em cada ensaio $(\mathrm{L})$

Tabela 13 - Teores mássicos $(\mathrm{m} / \mathrm{m})$ das soluções de peróxido de hidrogênio comercial usados nos ensaios

\begin{tabular}{cc}
\hline Fornecedor da solução de $\mathrm{H}_{2} \mathrm{O}_{2}$ & teor $_{\mathrm{H}_{2} \mathrm{O}_{2}}(\%)$ \\
\hline Caal & 30 \\
\hline Nuclear & 34 \\
\hline Reatec & 35 \\
\hline
\end{tabular}

Tabela 14 - Densidade das soluções de peróxido de hidrogênio em função do teor mássico

\begin{tabular}{cc}
\hline teor $_{\mathrm{H}_{2} \mathrm{O}_{2}(\%)}$ & $\rho_{\mathrm{H}_{2} \mathrm{O}_{2}}\left(\mathbf{g} / \mathbf{c m}^{3}\right)$ \\
\hline 30 & 1,1122 \\
\hline 35 & 1,1327 \\
\hline
\end{tabular}

A Eq.(20) pode ser utilizada para o cálculo da vazão de entrada de peróxido de hidrogênio, substituindo $V_{\mathrm{H}_{2} \mathrm{O}_{2}}$ por $v_{\mathrm{H}_{2} \mathrm{O}_{2}}$ (vazão volumétrica de solução de $\mathrm{H}_{2} \mathrm{O}_{2}$ ), $V_{\text {effuente }}$ por $v_{\text {effuente }}$ (vazão volumétrica de efluente) e definindo $\alpha=\frac{F_{\mathrm{H}_{2} \mathrm{O}_{2 o}}}{F_{\mathrm{COT}_{o}}}$. Neste caso, $F_{\mathrm{H}_{2} \mathrm{O}_{2 o}}$ é a vazão mássica de $\mathrm{H}_{2} \mathrm{O}_{2}$ e $F_{C O T_{o}}$ é a vazão mássica de COT na entrada do reator. Para o cálculo da vazão mássica, $m_{\mathrm{H}_{2} \mathrm{O}_{2}}$ deve ser substituída por $F_{\mathrm{H}_{2} \mathrm{O}_{2} \text { 。 }}$.

Para uma primeira estimativa da razão $\alpha=\frac{C_{\mathrm{H}_{2} \mathrm{O}_{2}}}{C O T_{o}}$ adequada para uma degradação efetiva pelo processo $\mathrm{UV} / \mathrm{H}_{2} \mathrm{O}_{2}$, foi adotada como hipótese que todo carbono presente no efluente estaria sob forma de propileno $\left(\mathrm{C}_{3} \mathrm{H}_{6}\right)$. A proporção estequiométrica de $\mathrm{H}_{2} \mathrm{O}_{2}$ necessária para oxidar o propileno segundo a equação a seguir é de 9:1. Portanto o valor estimado inicialmente para $\alpha$ foi:

$$
\begin{array}{ll}
\mathrm{C}_{3} \mathrm{H}_{6}+9 \mathrm{H}_{2} \mathrm{O}_{2} \Rightarrow 3 \mathrm{CO}_{2}+12 \mathrm{H}_{2} \mathrm{O} \\
3 \mathrm{~mol} \mathrm{C} & 9 \mathrm{~mol} \mathrm{H}_{2} \mathrm{O}_{2} \\
3 \cdot 12 \mathrm{~g} \mathrm{C} & 9 \cdot 34 \mathrm{~g} \mathrm{H}_{2} \mathrm{O}_{2}
\end{array} \Rightarrow \alpha=\frac{\mathrm{C}_{\mathrm{H}_{2} \mathrm{O}_{2}}}{\mathrm{COT}_{o}}=\frac{9 \cdot 34 \mathrm{~g}}{3 \cdot 12 \mathrm{~g}}=8,5 .
$$




\subsection{Metodologia de tratamento de dados}

\subsubsection{Rede Neural Artificial (RNA)}

$\mathrm{O}$ uso do sistema $\mathrm{UV} / \mathrm{H}_{2} \mathrm{O}_{2}$ para eliminação de poluentes tem sido objeto de estudo de muitos trabalhos (BELTRÁN; GONZÁLEZ, M.; GONZÁLEZ, J. F., 1997; CRITTENDEN et al., 1999; STEFAN; BOLTON, 1998). No entanto, devido à complexidade do sistema de reações envolvidas, os parâmetros cinéticos são de difícil determinação, levando a incertezas no projeto e no aumento de escala de reatores para fins industriais. $\mathrm{O}$ modelo de um reator baseado em princípios básicos requer a solução de conservação de momento, energia térmica e de massa multicomponentes. No caso de um foto-reator, o balanço de energia radiante é também necessário (CASSANO et al, 1995).

Sob estas condições, uma aproximação empírica baseada em redes neurais artificiais (RNA) para modelar a cinética de processos fotoquímicos pode ser convenientemente empregada (LIRA et al., 2005b). RNA são capazes de "aprender" a partir de um conjunto de dados experimentais, sem necessitar de conhecimentos de natureza físico-química do sistema (HAM; KOSTANIC, 2001). O neurônio humano serviu de inspiração para o neurônio artificial. RNA são tipicamente constituídas por neurônios (Figura 18) e por fluxos de informações entre eles, denominados de interconectores. Existem diferentes tipos de RNA, entre os quais a estrutura "feedforward" (rede de múltiplas camadas com sentido único) tem sido relatada em trabalhos como ferramenta para o ajuste de dados experimentais aplicados em reatores fotoquímicos (NASCIMENTO; OLIVEROS; BRAUN, 1994; TEIXEIRA; GUARDANI; NASCIMENTO, 2004). De acordo com a estrutura de rede "feedforward", a informação é propagada em um sentido único através dos neurônios distribuídos nas camadas de entrada, oculta e de saída. 


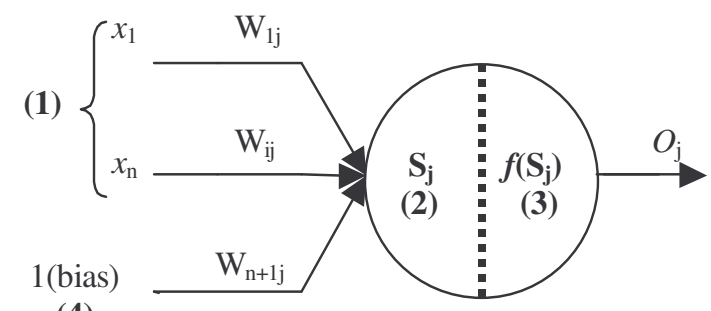

(4)

(1) Entradas $\left(x_{1} \ldots x_{\mathrm{n}}\right)$ com os pesos associados $\left(\mathrm{W}_{1 \mathrm{j}} \ldots \mathrm{W}_{\mathrm{ij}}\right)$;

(2) Dispositivo de soma:

$$
S_{j}=\sum_{i=1}^{n} W_{i, j} \cdot x_{i}+W_{n+1, j}
$$

(3) Função de ativação:

Pode ser de diversos tipos sendo que a função sigmoidal é a mais comum.

$$
O_{j}=f\left(S_{j}\right)=\frac{1}{\left(1+e^{-S_{j}}\right)} \text { (sigmoidal) }
$$

(4) Bias, termo de polarização.

Obs.: Neurônios da camada de entrada apenas normalizam os dados de entradas.

Figura 18 - Modelo não-linear de um neurônio artificial

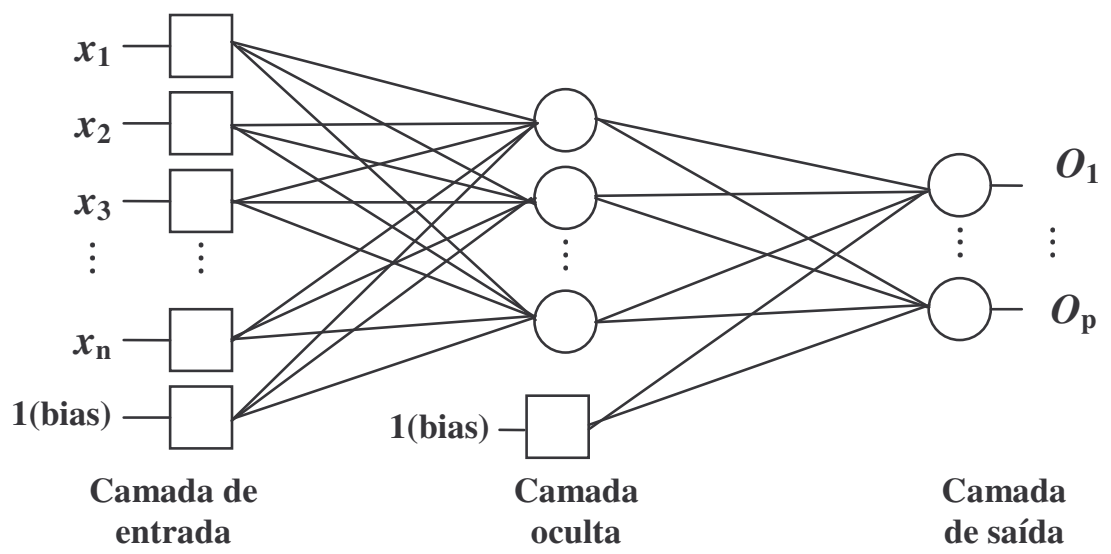

Figura 19 - Estrutura de uma rede neural artificial (RNA) do tipo "feedforward" com três camadas

Um dos problemas em modelar um processo por RNA é a escolha correta das variáveis de entrada e saída para descrever o processo adequadamente (BRAUN et al, 1993). Em sistemas fotoquímicos as variáveis de entrada escolhidas podem ser, por exemplo: potência da fonte de luz radiante, concentrações de contaminantes, de oxidantes e de catalisadores, $\mathrm{pH}$ e vazão (se o reator for contínuo). As variáveis de saída são, por exemplo, taxa de conversão e remoção de contaminantes. A escolha de variáveis convenientes é particular para cada caso.

O primeiro passo para o desenvolvimento de uma rede neural é coleta de dados experimentais relativos ao problema e sua separação em um conjunto de treinamento (LS) e conjunto de teste (TS). O segundo passo é a definição da estrutura da rede e de seus neurônios (topologia - número de camadas, número de neurônios em cada camada, etc.; parâmetros do algoritmo de treinamento; função de ativação). O terceiro passo é o treinamento da rede com os pares de dados de entradas e respostas normalizados $(x, y)$ contidos no LS. No presente trabalho, todas as variáveis foram normalizadas na faixa entre 0,1 e 0,9. 
A rede aprende por modificações sucessivas nos pesos de maneira a alcançar o valor mínimo da soma dos quadrados dos desvios entre as respostas calculadas e experimentais.

O método geralmente usado para a variação de pesos é o algoritmo de retropropagação, baseado no método do gradiente descendente (NASCIMENTO; OLIVEROS; BRAUN, 1994). O quarto passo é a validação da rede através da comparação das respostas calculadas e experimentais de um conjunto de dados independentes (conjunto de teste - TS).

Os programas utilizados para preparação dos dados, bem como para ajuste e simulação de redes neurais, foram desenvolvidos no LSCP/DEQ-EPUSP (NASCIMENTO; GUARDANI, 1998).

\subsubsection{Distribuição do tempo de residência (DTR)}

A função distribuição de tempos de residência $E(t)$ descreve de maneira quantitativa quanto tempo diferentes elementos de volume de fluido permanecem no reator. Para injeção em pulso, considerando um sistema no qual apenas o fluxo (isto é, sem dispersão) seja responsável pelo arrastamento de material através do reator, a função $E(t)$ é definida conforme a Eq.(22).

$$
E(t)=\frac{v(t) \cdot C(t)}{\int_{0}^{\infty} v(t) \cdot C(t) d t}
$$

Em que:

$\mathrm{C}(\mathrm{t})$ : concentração de traçador na saída do reator.

$\mathrm{v}(\mathrm{t})$ : vazão volumétrica

Como geralmente a vazão volumétrica é constante: $\mathrm{v}(\mathrm{t})=\mathrm{Q}, \mathrm{E}(\mathrm{t})$ pode ser expressa pela Eq.(23):

$$
E(t)=\frac{C(t)}{\int_{0}^{\infty} C(t) d t}
$$

Com base na Eq.(22), como o denominador representa a quantidade total de traçador alimentado, vale a propriedade: $\int_{0}^{\infty} E(t) d t=1$. 
Para a completa descrição de uma distribuição, três momentos são geralmente usados. O primeiro é a média da distribuição de tempos de residência, definido pela Eq.(24):

$\bar{t}=\frac{\int_{0}^{\infty} t \cdot E(t) d t}{\int_{0}^{\infty} E(t) d t}=\int_{0}^{\infty} t \cdot E(t) d t$

A média da distribuição de tempos de residência $(\bar{t})$ é igual ao tempo espacial ou tempo médio de residência $\left(\tau=\frac{V}{Q}\right)$ somente para sistemas fechados, isto é, sem dispersão (FOGLER, 1999).

O segundo momento, Eq.(25), é a variância da distribuição. A magnitude desse momento é um indicador de espalhamento da distribuição. Quanto maior este momento, maior é a dispersão na distribuição e maior é o desvio da idealidade em relação a um sistema de escoamento ideal pistonado (plug-flow).

$$
\sigma^{2}=\int_{0}^{\infty}(t-\bar{t})^{2} \cdot E(t) d t
$$

O terceiro momento (skewness), Eq.( 26 ), também calculado a partir da média, é relacionado à torção:

$s^{3}=\frac{1}{\sigma^{3 / 2}} \int_{0}^{\infty}(t-\bar{t})^{3} \cdot E(t) d t$

O terceiro momento é uma medida de simetria de dados da distribuição de probabilidade de uma variável. Uma curva normal apresenta o terceiro momento igual a "0", daí a utilidade desta medida para comparar outras distribuições com uma gaussiana ou normal. Uma medida negativa indica que a cauda negativa da distribuição é mais longa e uma medida positiva indica que a cauda positiva da distribuição é mais longa.

As funções de distribuição de tempos de residência podem ser expressas sob a forma adimensional, definindo o tempo adimensional como:

$\theta=\frac{t}{\tau}$

A função adimensional $E(\theta)$ pode ser definida como:

$E(\theta)=\tau \cdot E(t)$ 
A determinação da DTR permite diagnosticar problemas de escoamento nos reatores reais. Os principais desvios em relação aos reatores ideais são (LEVENSPIEL, 1962):

A) Existência de zonas de estagnação de fluido ou zonas mortas;

B) Curto-circuito e sub-passagem de fluido;

C) Existência de caminhos preferenciais, especialmente em operações em contracorrente;

D) Dispersão axial em reatores tubulares;

E) Segregação, resultante das condições de mistura.

A Figura 20 ilustra as DTRs para os reatores ideais e exemplos típicos de perfis de escoamento que apresentam desvios da idealidade causados pelos fenômenos descritos acima.

(a) Mistura

$\mathrm{E}(\theta)$

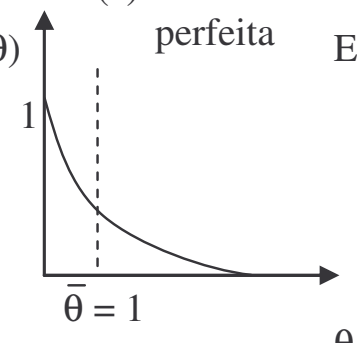

$\theta$

(d) Zona morta

$\mathrm{E}(\theta)$

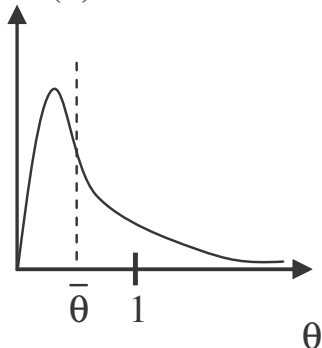

(g) Atrasado

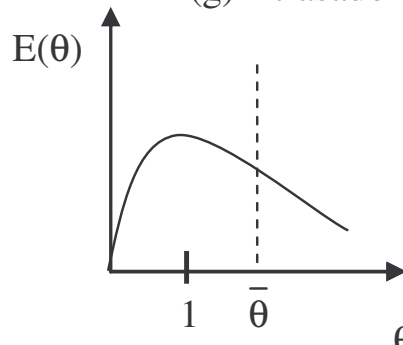

$\theta$ (b) Mistura

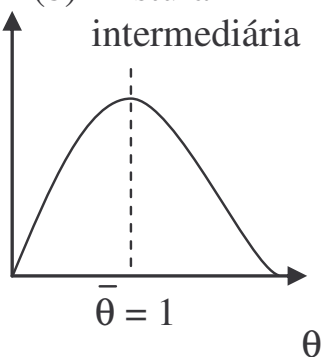

$\theta$

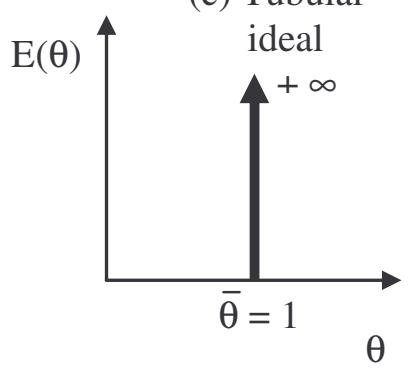

(e) Sub-passagem

$\mathrm{E}(\boldsymbol{\theta})$
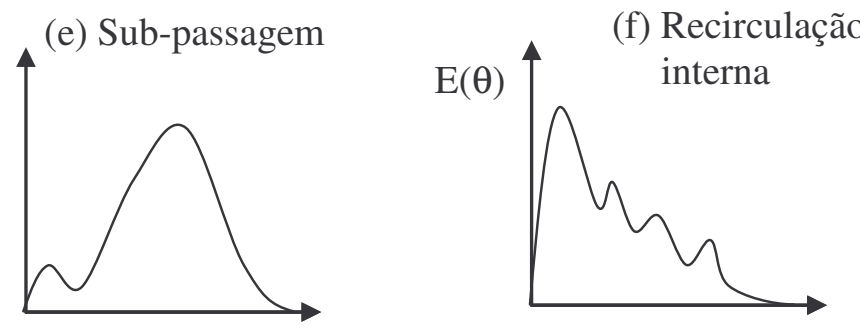

$\theta$

\section{(n)}


$\mathrm{Na}$ caracterização de escoamento de um reator não ideal, pode-se usar desde modelos mais simples (p. ex.: reatores CSTR em séries e reatores pistonados com dispersão axial), até modelos de escoamento hidrodinâmico baseados em redes complexas de reatores elementares interconectados (MARTIN, 2000; LECLERC et al., 2000).

Três conceitos geralmente envolvidos para descrever reatores não-ideais são: a distribuição do tempo de residência no sistema, a qualidade da mistura e o modelo usado para descrever o sistema. Todos estes três conceitos são considerados na descrição de desvios do padrão de mistura de reatores ideais e devem ser avaliados como características de mistura em reatores não-ideais. Em reatores reais, padrões de fluxo não-ideal existem, resultando em contato ineficaz e conversões mais baixas em relação aos reatores ideais. A não-idealidade pode ser contabilizada usando informações de macro-mistura (DTR) e de micro-mistura (micro-escala para prever conversões em reatores não ideais).

A DTR fornece o tempo que os diversos elementos de fluido permanecem no reator, mas não informa sobre a troca de matéria entre os elementos de fluido (por exemplo, mistura). A mistura nos meios reacionais é um dos principais fatores que controlam o comportamento dos reatores químicos. Para as reações de $1^{a}$ ordem, cuja conversão é independente da concentração, o conhecimento da DTR é o suficiente para calcular conversões. Entretanto para reações diferentes da de $1^{\text {a }}$ ordem, a DTR não é suficiente. Neste caso o grau de mistura das moléculas deve ser conhecido e os modelos de um ou dois parâmetros ajustáveis podem ser convenientemente empregados. 


\section{RESUltados E Discussões}

$\mathrm{Na}$ primeira fase do estudo foi realizado um conjunto de experimentos e análises preliminares para definição das condições mais adequadas das variáveis do processo de degradação em sistema de batelada. Esses experimentos indicaram a viabilidade técnica de se obterem taxas adequadas de degradação dos compostos orgânicos contidos nos efluentes por processo de foto-oxidação com peróxido de hidrogênio. Baseando-se nos resultados dos experimentos exploratórios, outros conjuntos de experimentos foram planejados a fim de refinar a busca para as condições ótimas do sistema, tanto do ponto de vista do próprio tratamento quanto do processo petroquímico. Com os resultados da primeira fase, foi possível ajustar um modelo empírico para a taxa de degradação dos compostos orgânicos, baseado em redes neurais, assim como uma estimativa preliminar da viabilidade econômica da implementação do processo para tratamento de efluentes industrias.

$\mathrm{Na}$ segunda fase, foi estudado o comportamento de degradação do efluente E1 no sistema fotoquímico contínuo, a fim de se obter informação sobre o comportamento do sistema em operação contínua. Nesta fase, foi medida a distribuição de tempos de residência e foram ajustados modelos de reatores nãoideais.

O percentual de remoção de COT durante a reação de degradação foi calculado segundo a Eq.(29). A taxa média de remoção de COT é apresentada pela Eq.(30).

$$
\begin{aligned}
& X_{t}=\text { Percentual de Re moção de COT }(\%)=100\left[1-\left(\frac{\text { COT }_{t}}{\text { COT }_{0}}\right)\right] \\
& r_{t}=\frac{X_{t}}{\Delta t} \cdot \text { COT }_{o}
\end{aligned}
$$

A fim de comparar experimentos, e conseqüentemente analisar 0 desempenho do processo num determinado aspecto e estudar os efeitos das variáveis, foi estabelecido arbitrariamente um limite aceitável de variação para COT。 de $\pm 25 \%$, ou seja, experimentos cujos valores de COT。 estejam fora desse limite não são comparados.

A sensibilidade de medida de COT e a varabilidade das amostras foram testadas medindo-se aleatoriamente amostras dos efluentes (Figura 21). $O$ erro 
experimental engloba erro do aparelho de análise de COT e de preparação das amostras.

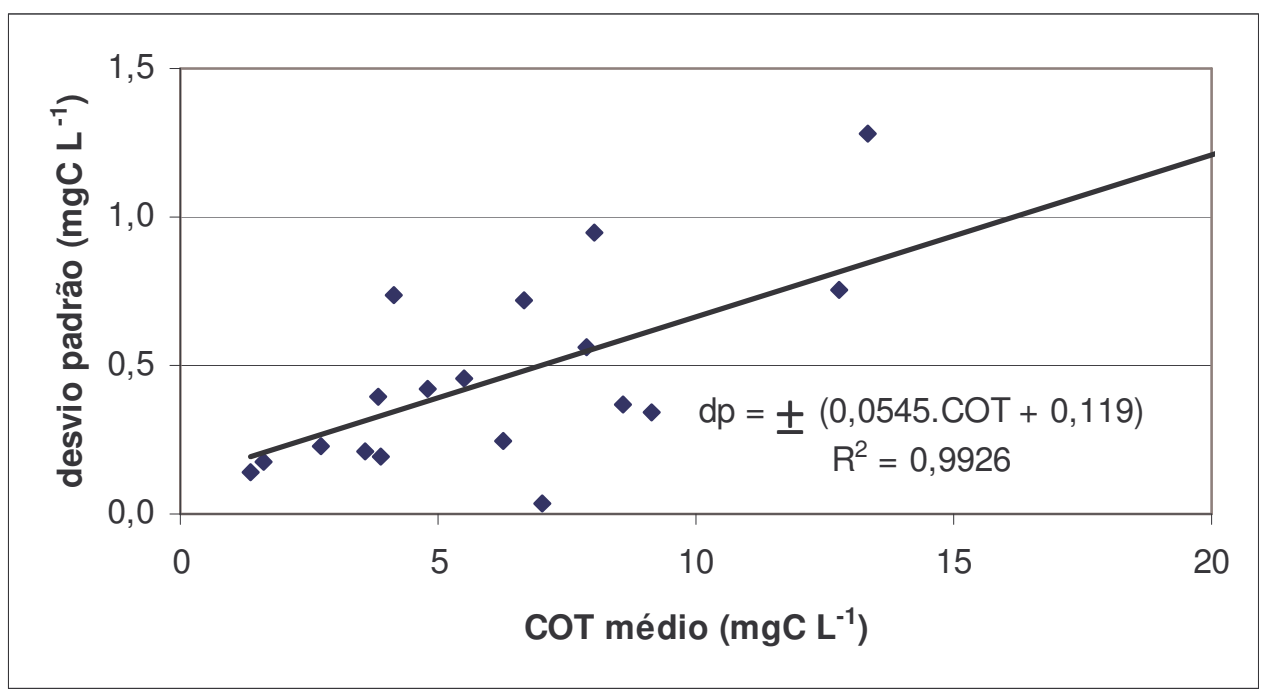

Figura 21 - Erro na medida de COT em função dos valores médios

Pela função ajustada aos pontos da Figura 21, observa-se que para amostras contendo baixo teor de matéria orgânica (até $15 \mathrm{mgC} \mathrm{L}^{-1}$ ), o erro foi estimado em até $\pm 1,0 \mathrm{mgC} \mathrm{L}^{-1}$. Para amostras contendo alto teor de matéria orgânica $(\sim 223 \mathrm{mgC} \mathrm{L}$ ${ }^{1}$ ), o erro foi estimado em $\pm 12 \mathrm{mgC} \mathrm{L}^{-1}$.

\subsection{Primeira fase}

\subsubsection{Testes preliminares}

Inicialmente foram realizados testes preliminares de degradação fotoquímica utilizando lâmpada a vapor de mercúrio de $400 \mathrm{~W}$ com o objetivo de investigar a viabilidade técnica de aplicação do processo fotoquímico e ajustar o procedimento experimental para a forma de adição de oxidante e o tempo de reação.

Resultados dos testes preliminares são mostrados na Figura 22 até Figura 26. Os resultados experimentais sugerem a viabilidade da aplicação do sistema $\mathrm{UV} / \mathrm{H}_{2} \mathrm{O}_{2}$ em todas as correntes de efluente do processo, alcançando percentuais finais de remoção de carbono orgânico total entre (55 e 100\%). Devido às diferenças nos valores iniciais de COT para cada um dos efluentes, os dados foram 
normalizados para efeito de comparação. Para os efluentes com baixo teor de matéria orgânica (E1, E2 e E3) observa-se uma queda acentuada de COT até aproximadamente 20 minutos de reação e, a partir desse ponto, observa-se uma taxa de remoção de COT muito baixa (p. ex.: experimentos BE1-1, BE1-2, BE2-3, BE2-5, BE3-2, BE3-3) ou nula (p. ex.: experimentos BE1-3, BE2-1, BE2-2, BE2-4, BE3-1). Para o efluente com alto teor de matéria orgânica (efluente E4), a taxa de remoção de COT foi relativamente mais lenta do que para os efluentes de baixa COT, uma vez que para um mesmo tempo de reação, o percentual de COT removido foi menor. Analisando-se os experimentos BE3-1 e BE4-1, que possuem condições experimentais semelhantes ( $\alpha=9 ; \mathrm{P}=400 \mathrm{~W}$ e $\left.\mathrm{T}=50^{\circ} \mathrm{C}\right)$, os percentuais de remoção de COT em 20min foram 92 e $28 \%$, respectivamente. A adição de $\mathrm{H}_{2} \mathrm{O}_{2}$ em ambos os experimentos foi feita de forma descontínua em quatro partes iguais durante o tempo de reação. Por isso 0 intervalo de adição de $\mathrm{H}_{2} \mathrm{O}_{2}$ para $\mathrm{O}$ experimento BE4-1 (30min) foi maior do que para o experimento (BE3-1). Nota-se na Figura 26 que para efluente com alta $\mathrm{COT}_{0}$ o tempo requerido para remoções satisfatórias de COT, em torno de $80 \%$, é de $80 \mathrm{~min}$. De acordo com esta análise foram adotados tempos de reação para os ensaios seguintes entre $60 \mathrm{~min}$ (condições experimentais mais severas com maiores concentrações de $\mathrm{H}_{2} \mathrm{O}_{2}$, alta potência da lâmpada e menores $\mathrm{COT}_{\circ}$ ) e $180 \mathrm{~min}$ (condições experimentais mais amenas com menores concentrações de $\mathrm{H}_{2} \mathrm{O}_{2}$, menor potência da lâmpada e maiores $\mathrm{COT}_{0}$ ).

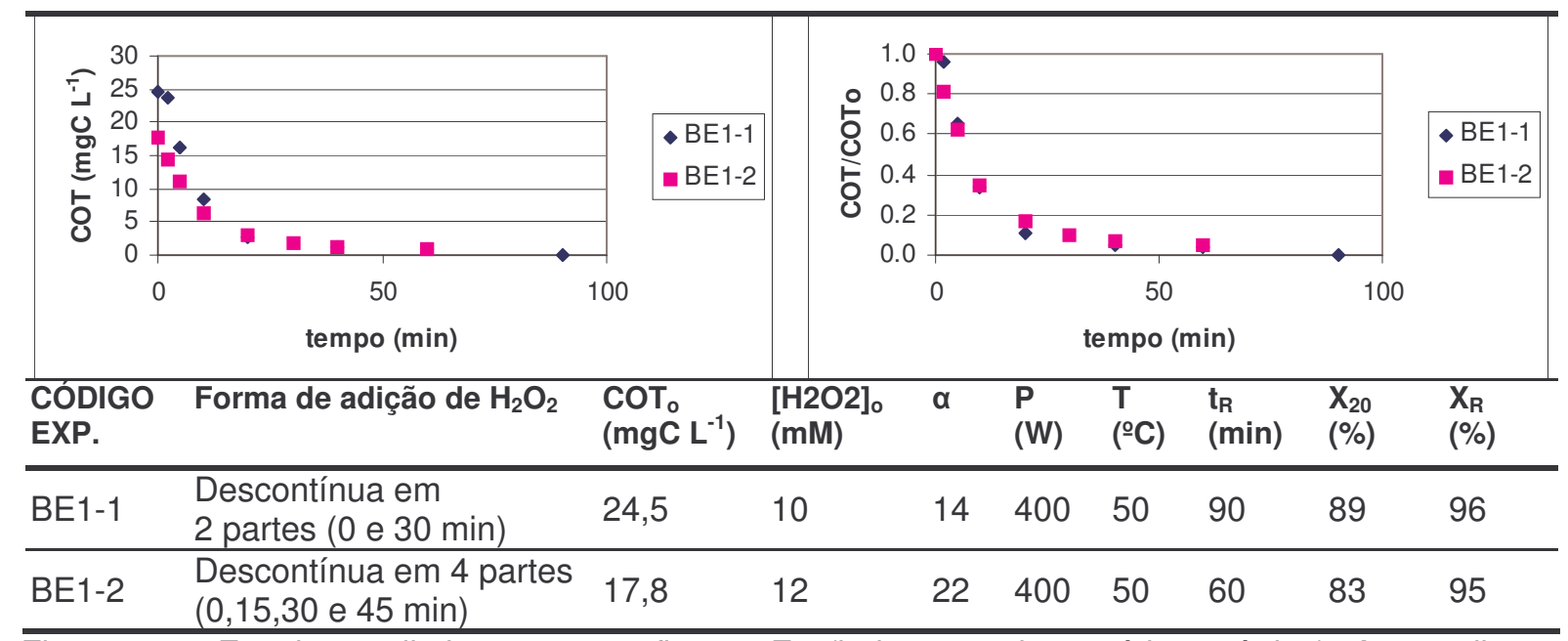

Figura 22 - Ensaios preliminares para efluente E1 (baixo teor de matéria orgânica). As condições experimentais são indicadas na tabela. Gráfico à esquerda: resultados não normalizados; gráfico à direita: resultados normalizados. 
Como previsto, maiores remoções de COT são alcançadas nos experimentos cuja dosagem de $\mathrm{H}_{2} \mathrm{O}_{2}$ em relação ao $\mathrm{COT}_{0}$ foi maior, ou seja, maior razão $\alpha$, independentemente da forma de adição de $\mathrm{H}_{2} \mathrm{O}_{2}$ ou do nível de $\mathrm{COT}_{0}$. Em virtude dos resultados alcançados nos experimentos preliminares foi definida a faixa de valores para razão a entre 3 e 40.

No ensaio da Figura 23, cuja forma de adição de $\mathrm{H}_{2} \mathrm{O}_{2}$ ocorreu no início, observa-se a remoção de COT do efluente E1 é possível mesmo para baixos valores de teor de carbono orgânico inicial (COTo). Neste ensaio, o valor de COT o foi menor do que em outras amostras recebidas em períodos distintos. Foi possível identificar dois outliers (exp B1-3, $t=5 \mathrm{~min}$ e $t=60 \mathrm{~min}$ ), fato possivelmente devido a erros de amostragem e análise. Outra possível explicação é a baixa sensibilidade do equipamento de análise de COT para a detecção de baixos teores de carbono orgânico.

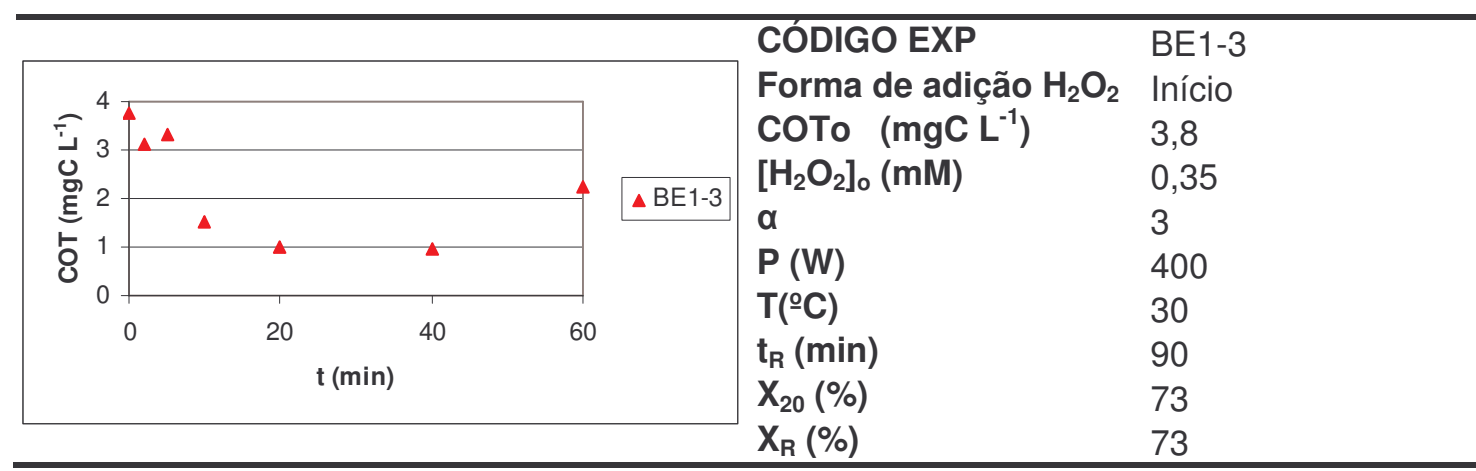

Figura 23 - Ensaios preliminares para efluente E1 (baixo teor de matéria orgânica). As condições experimentais estão indicadas ao lado da figura.

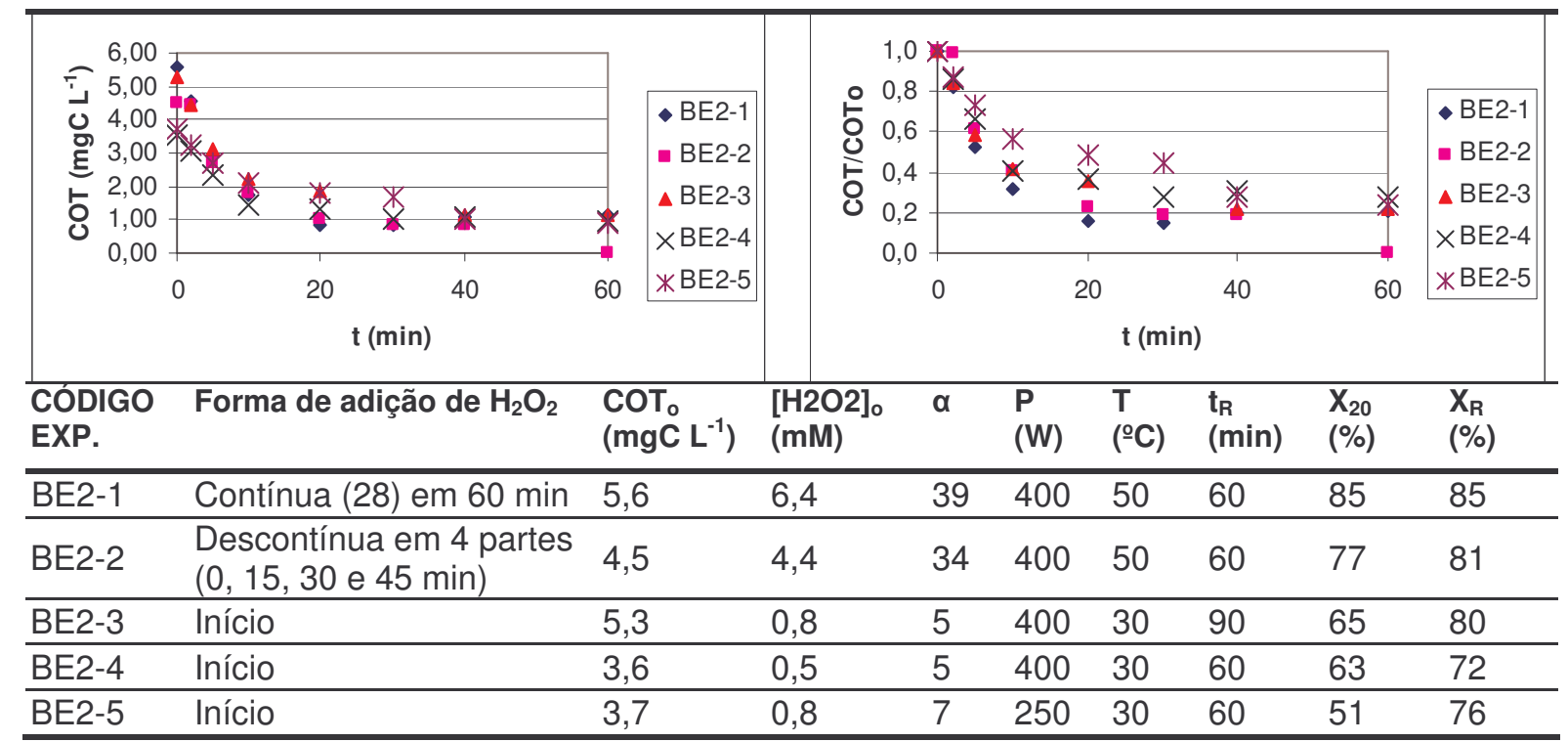

Figura 24 - Ensaios preliminares para efluente E2 (baixo teor de matéria orgânica). As condições experimentais são indicadas na tabela. Gráfico à esquerda: resultados não normalizados; gráfico à direita: resultados normalizados. 
Um único experimento (BE2-1) foi realizado com adição contínua de $\mathrm{H}_{2} \mathrm{O}_{2}$ por bomba peristáltica (Figura 24). Comparando-se com o experimento BE2-2, no qual a adição foi feita de forma descontínua em 4 partes iguais, observa-se que a forma de adição contínua ou descontínua pouco influenciou a remoção de COT.

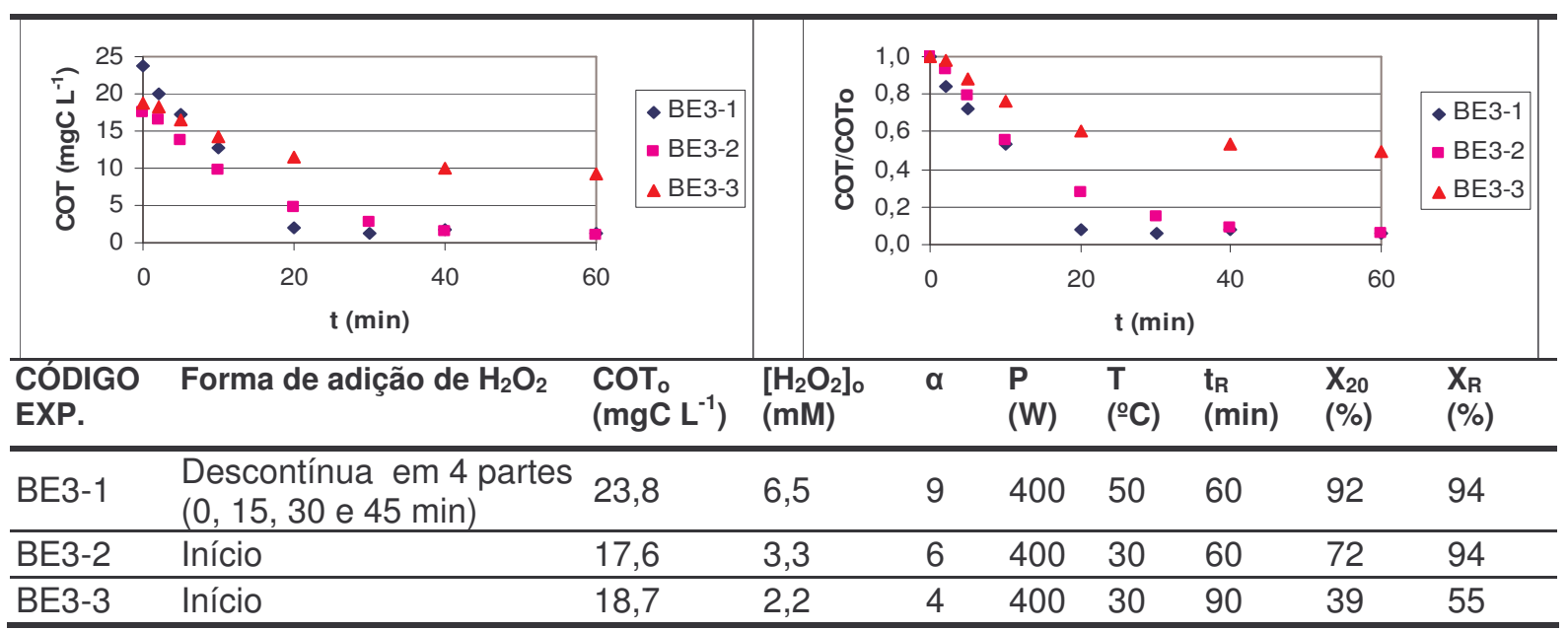

Figura 25 - Ensaios preliminares para efluente E3 (baixo teor de matéria orgânica). As condições experimentais são indicadas na tabela. Gráfico à esquerda: resultados não normalizados; gráfico à direita: resultados normalizados.

Em geral, observa-se na Figura 25 e Figura 26, que quantos maiores as doses de $\mathrm{H}_{2} \mathrm{O}_{2}$, maiores são as remoções de COT alcançadas.

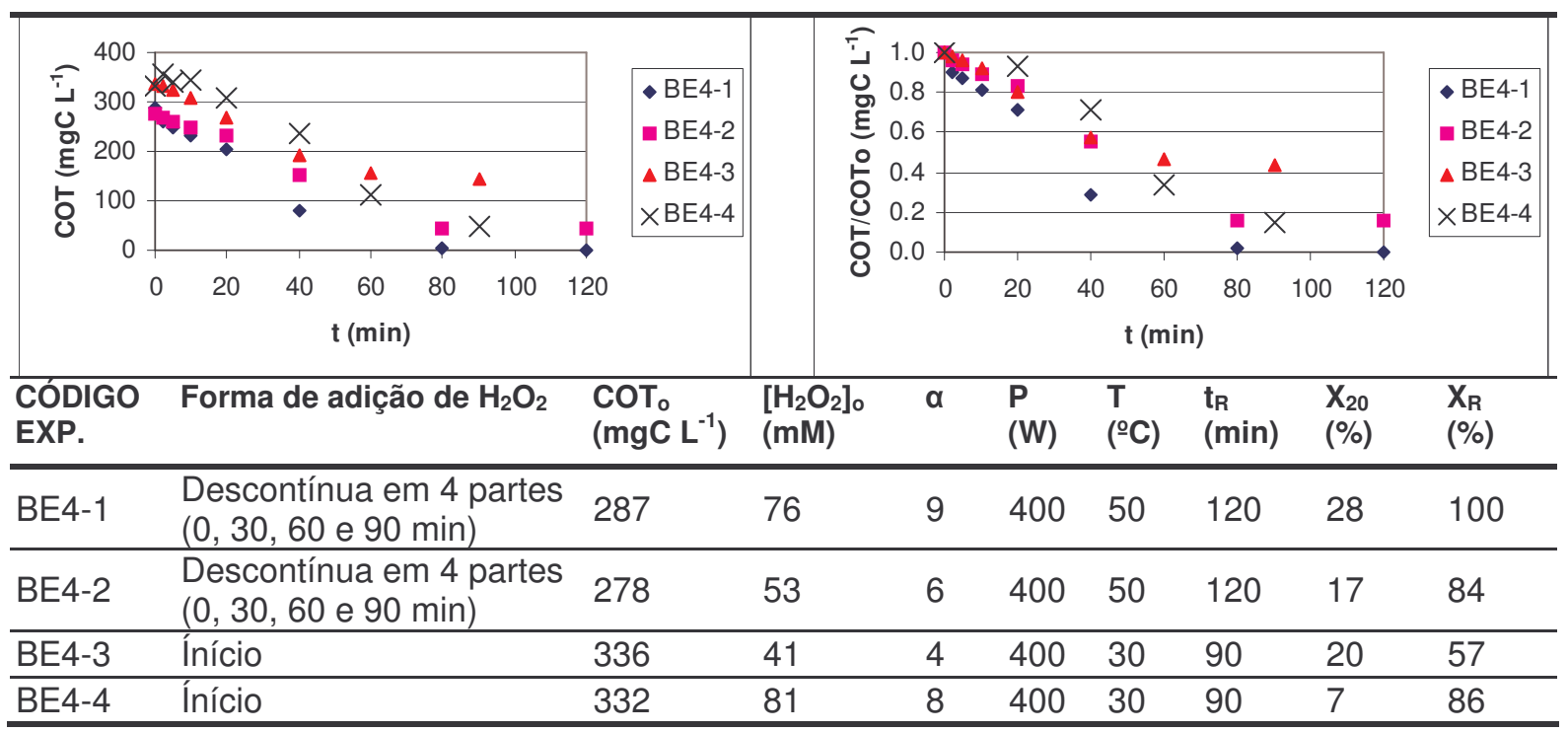

Figura 26 - Ensaios preliminares para efluente E4 (alto teor de matéria orgânica). As condições experimentais são indicadas na tabela. Gráfico à esquerda: resultados não normalizados; gráfico à direita: resultados normalizados.

A forma de adição do reagente oxidante $\left(\mathrm{H}_{2} \mathrm{O}_{2}\right)$ não causou efeito significativo na taxa de degradação fotoquímica como pode ser observado na Figura 27, portanto, adotou-se a forma de adição descontínua, com adição sempre no início do experimento. 


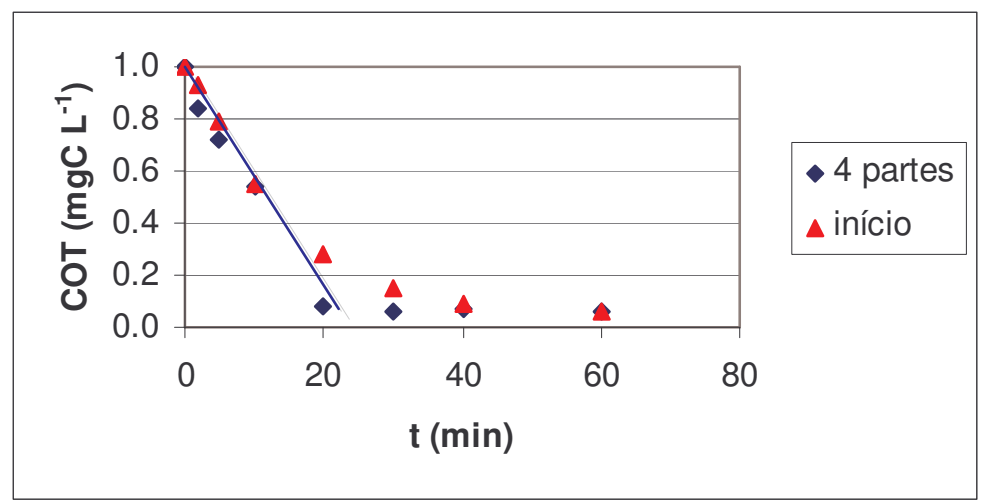

Figura 27 - Forma de adição de peróxido. Condições experimentais: Efluente E3; $P=400 \mathrm{~W}$; em 4 partes $(0,15,30$ e $45 \mathrm{~min}):\left[\mathrm{H}_{2} \mathrm{O}_{2}\right]=6,5 \mathrm{mM}, \mathrm{COT}_{0}=24 \mathrm{mgC} \mathrm{L}^{-1}, \alpha=9, \mathrm{~T}=50^{\circ} \mathrm{C}$; início: $\left[\mathrm{H}_{2} \mathrm{O}_{2}\right]=3,3 \mathrm{mM}$, $\mathrm{COT}_{0}=18 \mathrm{mgC} \mathrm{L}^{-1}, \alpha=6, \mathrm{~T}=30^{\circ} \mathrm{C}$.

Experimentos de referência, na ausência de luz, foram realizados com algumas amostras de efluente. A Figura 28 apresenta resultados representativos desses experimentos.

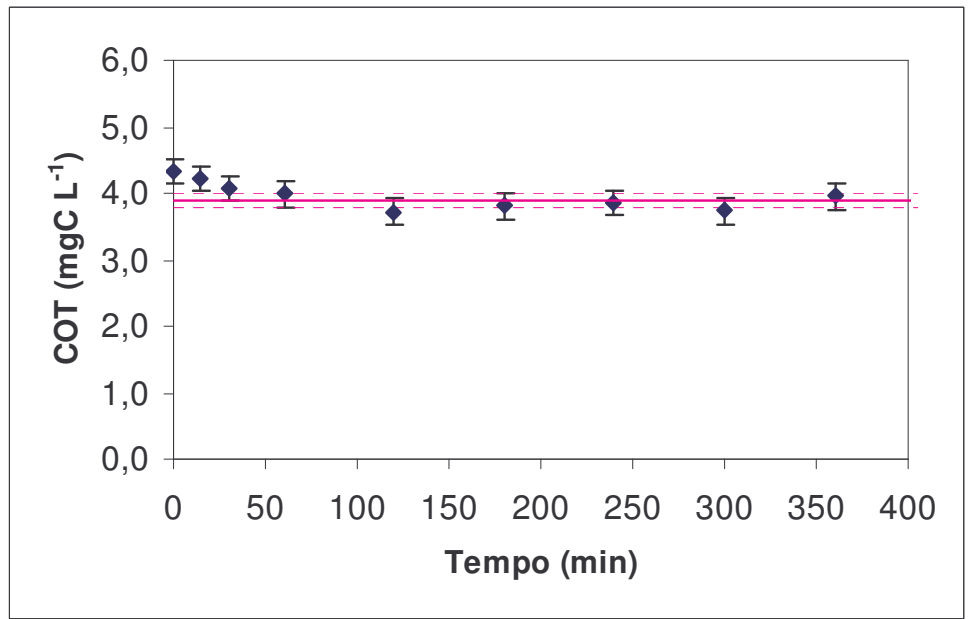

Figura 28 - Experimento na ausência de luz. Condições experimentais: efluente E3; adição de $\mathrm{H}_{2} \mathrm{O}_{2}$ no início; $\left[\mathrm{H}_{2} \mathrm{O}_{2}\right]_{0}=6,9 \mathrm{mM} ; \mathrm{COT}_{0}=4 \mathrm{mgC} \mathrm{L}^{-1} ; \alpha=60 ; \mathrm{T}=30^{\circ} \mathrm{C}$. Barra de erro: $\pm 0,20 \mathrm{mgC} \mathrm{L}^{-1}$. Intervalo de confiança para média de $95 \%$ : $\pm 0,11 \mathrm{mgC} \mathrm{L}^{-1}$.

Na Figura 28, observa-se que a ausência de luz implica redução significativa na remoção de COT do efluente, uma vez que, na ausência de luz, não é gerado radical hidroxila.

\subsubsection{Testes sistemáticos}

Em seguida, foram investigados os efeitos de 4 variáveis: temperatura da reação, potência da lâmpada, concentração de $\mathrm{H}_{2} \mathrm{O}_{2}$ (valor de $\alpha$ ) e tempo de reação sobre a taxa de remoção de COT. A Tabela 15 apresenta, em resumo, as variáveis 
investigadas e suas respectivas faixas de valores de trabalho. A Tabela 16 até Tabela 19 mostram as condições experimentais em cada ensaio.

Tabela 15 - Variáveis investigadas e seus respectivos valores

\begin{tabular}{cc}
\hline Variáveis & Valores \\
\hline Fonte de Luz $(\mathrm{W})$ & $80,125,250$ e 400 \\
\hline Temperatura $\left({ }^{\circ} \mathrm{C}\right)$ & 30 e 50 \\
\hline Tempo de reação $(\mathrm{min})$ & $60,90,120$ e 180 \\
\hline Concentração de peróxido $(\mathrm{mM})^{*}$ & 0,4 a 141,2 \\
\hline$\alpha(\mathrm{mg} \mathrm{H} 2 \mathrm{O} 2 / \mathrm{mg} \mathrm{C})$ & 1,7 a 39,0
\end{tabular}

* Refere-se à concentração de peróxido de hidrogênio no sistema batelada

A princípio, a intenção era realizar experimentos baseados numa metodologia de planejamento experimental (BARROS NETO; SCARMÍNIO; BRUNS, 2002) para avaliação dos efeitos das variáveis. No entanto, devido ao fato de terem sido usados efluentes reais, o controle sobre o COT。 não foi possível, conforme discutido anteriormente, e isso afetou os cálculos da variável dependente do COT, ou seja, a concentração de $\mathrm{H}_{2} \mathrm{O}_{2}$. Optou-se, então, por avaliar os efeitos comparando-se os experimentos realizados sob condições experimentais semelhantes.

A discussão dos resultados é feita nos itens a seguir, nos quais são apresentados os efeitos da intensidade de luz (potência da lâmpada), da quantidade de $\mathrm{H}_{2} \mathrm{O}_{2}$ adicionada ao sistema e da temperatura de reação. Uma análise sobre o comportamento do pH ao longo da reação e uma avaliação preliminar em relação à cinética de reação também são apresentadas.

Tabela 16 - Condições experimentais e percentuais de remoção de carbono orgânico (Eq. 29 ) para os experimentos de tratamento do efluente $\mathrm{E} 1$ por sistema $\mathrm{UV} / \mathrm{H}_{2} \mathrm{O}_{2}$.

\begin{tabular}{lccccccccc}
\hline CÓdIGO & $\begin{array}{c}\mathbf{C O T}_{0} \\
\left(\mathbf{m g C ~ L}^{-1}\right)\end{array}$ & $\begin{array}{c}{\left[\mathbf{H}_{2} \mathbf{O}_{2}\right]_{0}} \\
(\mathbf{m M})\end{array}$ & $\alpha$ & $\mathbf{P}(\mathbf{W})$ & $\mathbf{T}(\mathbf{-} \mathbf{C})$ & $\mathbf{t}_{\mathbf{R}}(\mathbf{m i n})$ & $\mathbf{X}_{\mathbf{2 0}}(\%)$ & $\mathbf{X}_{60}(\%)$ & $\mathbf{X}_{\mathbf{R}}(\%)$ \\
\hline BE1-1* $^{+}$ & 24,5 & 10 & 14 & 400 & 50 & 90 & 89 & 96 & 100 \\
\hline BE1-2*+ & 17,8 & 12 & 22 & 400 & 50 & 60 & 83 & 95 & 95 \\
\hline BE1-3* & 3,8 & 0,4 & 3 & 400 & 30 & 90 & 73 & $73^{\Delta}$ & $73^{\Delta}$ \\
\hline BE1-4 & 7,0 & 0,8 & 4 & 80 & 30 & 90 & 29 & 51 & 53 \\
\hline BE1-5 & 7,0 & 1,5 & 7 & 80 & 30 & 120 & 20 & 51 & 60 \\
\hline BE1-6 & 7,8 & 3,1 & 13 & 80 & 30 & 120 & 41 & 64 & 67 \\
\hline BE1-7 & 6,2 & 0,8 & 4 & 80 & 50 & 120 & 24 & $37^{\Delta}$ & 38 \\
\hline BE1-8 & 5,4 & 1,5 & 10 & 80 & 50 & 120 & 23 & 50 & 54 \\
\hline BE1-9 & 6,4 & 3,1 & 17 & 80 & 50 & 120 & 35 & 64 & 66 \\
\hline BE1-10 & 9,1 & 0,5 & 2 & 125 & 30 & 120 & 35 & 66 & 80 \\
\hline BE1-11 & 8,1 & 1,0 & 4 & 125 & 30 & 120 & 51 & 88 & 88 \\
\hline BE1-12 & 11,6 & 2,0 & 6 & 125 & 30 & 120 & 79 & 76 & 86 \\
\hline BE1-13 & 7,8 & 2,0 & 9 & 125 & 30 & 120 & 84 & 86 & 87 \\
\hline BE1-14 & 7,6 & 2,0 & 9 & 80 & 30 & 120 & 27 & 74 & 83 \\
\hline BE1-15 & 7,8 & 2,0 & 9 & 250 & 30 & 120 & 87 & 87 & 87 \\
\hline BE1-16 & 7,5 & 2,0 & 9 & 400 & 30 & 120 & 85 & 85 & 88 \\
\hline
\end{tabular}

* ensaios dos testes preliminares; ${ }^{+}$adição de $\mathrm{H}_{2} \mathrm{O}_{2}$ ao longo do ensaio, nos demais experimentos esta adição ocorreu no início; ${ }^{\Delta}$ valores inferidos a partir da tendência da curva de remoção de COT. 
Tabela 17 - Condições experimentais e percentuais de remoção de carbono orgânico (Eq. 29 ) para os experimentos de tratamento do efluente E2 por sistema UV/ $\mathrm{H}_{2} \mathrm{O}_{2}$.

\begin{tabular}{lccccccccc}
\hline Código & $\begin{array}{c}\mathbf{C O T}_{0} \\
\left(\mathbf{m g C ~ L}^{-1}\right)\end{array}$ & $\begin{array}{c}\left.\mathbf{H}_{2} \mathbf{O}_{2}\right]_{\circ} \\
(\mathbf{m M})\end{array}$ & $\alpha$ & $\mathbf{P}(\mathbf{W})$ & $\mathbf{T}\left({ }^{\circ} \mathbf{C}\right)$ & $\mathbf{t}_{\mathbf{R}}(\mathbf{m i n})$ & $\mathbf{X}_{20}(\%)$ & $\mathbf{X}_{60}(\%)$ & $\mathbf{X}_{\mathbf{R}}(\%)$ \\
\hline BE2-1*+ $^{*}$ & 5,6 & 6,4 & 39 & 400 & 50 & 60 & 85 & 79 & 79 \\
\hline BE2-2 $^{+}$ & 4,5 & 4,4 & 34 & 400 & 50 & 60 & 77 & 100 & 100 \\
\hline BE2-3 & 5,3 & 0,8 & 5 & 400 & 30 & 90 & 65 & 79 & 80 \\
\hline BE2-4* & 3,6 & 0,5 & 5 & 400 & 30 & 60 & 63 & 72 & 72 \\
\hline BE2-5* & 3,7 & 0,8 & 7 & 250 & 30 & 60 & 51 & 76 & 76 \\
\hline BE2-6 & 9,5 & 2,3 & 8 & 80 & 30 & 120 & 22 & 80 & 86 \\
\hline BE2-7 & 8,8 & 2,3 & 9 & 80 & 30 & 120 & 41 & 76 & 82 \\
\hline BE2-8 & 9,4 & 1,2 & 4 & 80 & 30 & 120 & 32 & 67 & 83 \\
\hline BE2-9 & 9,1 & 4,9 & 18 & 80 & 30 & 120 & 41 & 72 & 83 \\
\hline BE2-10 & 9,5 & 2,3 & 8 & 80 & 50 & 120 & 50 & 83 & 85 \\
\hline BE2-11 & 8,6 & 1,2 & 5 & 80 & 50 & 120 & 40 & 69 & 71 \\
\hline BE2-12 & 8,9 & 4,9 & 19 & 80 & 50 & 120 & 61 & 77 & 79 \\
\hline BE2-13 & 7,3 & 0,6 & 3 & 125 & 30 & 120 & 27 & 59 & 60 \\
\hline BE2-14 & 9,5 & 0,5 & 2 & 125 & 30 & 120 & 50 & 66 & 84 \\
\hline BE2-15 & 7,8 & 1,2 & 5 & 125 & 30 & 120 & 68 & 86 & 88 \\
\hline BE2-16 & 9,6 & 1,0 & 3 & 125 & 30 & 120 & 38 & 65 & 71 \\
\hline BE2-17 & 8,5 & 2,5 & 10 & 125 & 30 & 120 & 82 & 89 & 95 \\
\hline BE2-18 & 8,0 & 1,9 & 8 & 125 & 30 & 120 & 45 & 78 & 79 \\
\hline
\end{tabular}

Tabela 18 - Condições experimentais e percentuais de remoção de carbono orgânico (Eq. 29 ) para os experimentos de tratamento do efluente $\mathrm{E} 3$ por sistema $\mathrm{UV} / \mathrm{H}_{2} \mathrm{O}_{2}$.

\begin{tabular}{cccccccccc}
\hline CódiGo & $\begin{array}{c}\mathbf{C O T}_{0} \\
\left(\mathbf{m g C ~ L}^{-1}\right)\end{array}$ & $\begin{array}{c}\left.\mathbf{H}_{2} \mathbf{O}_{2}\right]_{\circ} \\
(\mathbf{m M})\end{array}$ & $\alpha$ & $\mathbf{P}(\mathbf{W})$ & $\mathbf{T}\left({ }^{-} \mathbf{C}\right)$ & $\mathbf{t}_{\mathbf{R}}(\mathbf{m i n})$ & $\mathbf{X}_{20}(\%)$ & $\mathbf{X}_{60}(\%)$ & $\mathbf{X}_{\mathbf{R}}(\%)$ \\
\hline BE3-1*+ & 23,8 & 6,5 & 9 & 400 & 50 & 60 & 92 & 94 & 94 \\
\hline BE3-2 & 17,6 & 3,3 & 6 & 400 & 30 & 60 & 72 & 94 & 94 \\
\hline BE3-3* & 18,7 & 2,2 & 4 & 400 & 30 & 90 & 39 & 50 & 55 \\
\hline BE3-4 & 14,1 & 4,0 & 10 & 250 & 30 & 60 & 90 & 93 & 93 \\
\hline BE3-5 & 12,9 & 8,0 & 21 & 250 & 30 & 60 & 84 & 92 & 92 \\
\hline BE3-6 & 11,7 & 2,0 & 6 & 250 & 30 & 60 & 75 & 90 & 90 \\
\hline BE3-7 & 12,1 & 4,0 & 11 & 250 & 50 & 60 & 84 & 84 & 84 \\
\hline BE3-8 & 12,7 & 2,0 & 5 & 250 & 50 & 60 & 84 & 87 & 87 \\
\hline BE3-9 & 13,6 & 8,0 & 20 & 250 & 50 & 60 & 83 & 90 & 90 \\
\hline BE3-10 & 12,5 & 4,0 & 11 & 80 & 30 & 120 & 41 & 83 & 89 \\
\hline BE3-11 & 13,2 & 8,0 & 21 & 80 & 30 & 120 & 62 & 83 & 88 \\
\hline BE3-12 & 13,0 & 2,4 & 6 & 80 & 30 & 120 & 14 & 78 & 84 \\
\hline BE3-13 & 12,0 & 4,0 & 11 & 80 & 50 & 120 & 54 & 83 & 87 \\
\hline BE3-14 & 13,6 & 8,0 & 20 & 80 & 50 & 120 & 76 & 88 & 89 \\
\hline BE3-15 & 11,7 & 2,0 & 6 & 80 & 50 & 120 & 38 & 81 & 84 \\
\hline BE3-16 & 8,8 & 1,0 & 4 & 125 & 30 & 120 & 49 & 70 & 71 \\
\hline BE3-17 & 8,8 & 2,0 & 8 & 125 & 30 & 120 & 68 & 80 & 80 \\
\hline BE3-18 & 8,1 & 4,0 & 17 & 125 & 30 & 120 & 75 & 84 & 83 \\
\hline
\end{tabular}

* ensaios dos testes preliminares; ${ }^{+}$adição de $\mathrm{H}_{2} \mathrm{O}_{2}$ ao longo do ensaio, nos demais experimentos esta adição ocorreu no início; ${ }^{\Delta}$ valores inferidos a partir da tendência da curva de remoção de COT. 
Tabela 19 - Condições experimentais e percentuais de remoção de carbono orgânico (Eq. 29 ) para os experimentos de tratamento do efluente E4 por sistema UV/ $\mathrm{H}_{2} \mathrm{O}_{2}$.

\begin{tabular}{|c|c|c|c|c|c|c|c|c|c|}
\hline CÓDIGO & $\begin{array}{c}\mathrm{COT}_{0} \\
\left(\mathrm{mgC} \mathrm{L}^{-1}\right)\end{array}$ & $\begin{array}{c}\left.\mathrm{H}_{2} \mathrm{O}_{2}\right]_{\circ} \\
(\mathrm{mM})\end{array}$ & $\alpha$ & $P(W)$ & $\mathrm{T}\left({ }^{\circ} \mathrm{C}\right)$ & $t_{R}(\min )$ & $X_{20}(\%)$ & $X_{60}(\%)$ & $X_{R}(\%)$ \\
\hline BE4-1*+ & 287 & 76 & 9 & 400 & 50 & 120 & 28 & 93 & 100 \\
\hline BE4-2 $2^{*+}$ & 278 & 53 & 6 & 400 & 50 & 120 & 17 & 69 & 84 \\
\hline BE4-3* & 336 & 41 & 4 & 400 & 30 & 90 & 20 & 54 & 57 \\
\hline BE4-4* & 332 & 81 & 8 & 400 & 30 & 90 & 7 & 66 & 86 \\
\hline BE4-5 & 280 & 71 & 9 & 250 & 30 & 120 & 14 & 87 & 96 \\
\hline BE4-6 & 274 & 141 & 18 & 250 & 30 & 120 & 29 & 92 & 98 \\
\hline BE4-7 & 308 & 71 & 8 & 250 & 50 & 140 & 38 & 91 & 97 \\
\hline BE4-8 & 271 & 141 & 18 & 250 & 50 & 120 & 55 & 97 & 99 \\
\hline BE4-10 & 202 & 13 & 2 & 125 & 30 & 180 & 4 & 8 & 19 \\
\hline BE4-11 & 198 & 27 & 5 & 125 & 30 & 180 & 0 & 12 & 41 \\
\hline BE4-12 & 195 & 53 & 9 & 125 & 30 & 180 & 0 & 57 & 88 \\
\hline BE4-13 & 197 & 13 & 2 & 80 & 30 & 180 & 9 & 6 & 19 \\
\hline BE4-14 & 193 & 27 & 5 & 80 & 30 & 180 & 1 & 6 & 40 \\
\hline BE4-15 & 205 & 53 & 9 & 80 & 30 & 180 & 0 & 5 & 77 \\
\hline
\end{tabular}

${ }^{*}$ ensaios dos testes preliminares; ${ }^{+}$adição de $\mathrm{H}_{2} \mathrm{O}_{2}$ ao longo do ensaio, nos demais experimentos esta adição ocorreu no início; ${ }^{\Delta}$ valores inferidos a partir da tendência da curva de remoção de COT.

\subsubsection{Efeito da potência da lâmpada}

Para avaliar o efeito da potência das lâmpadas para cada uma das quatro amostras de efluente, os ensaios, que apresentam as mesmas condições de relação a e de temperatura, foram comparados. Os gráficos, da Figura 29 até a Figura 36, mostram a relação entre a potência da lâmpada e a quantidade de carbono orgânico total ao longo do tempo, para os quatro efluentes.

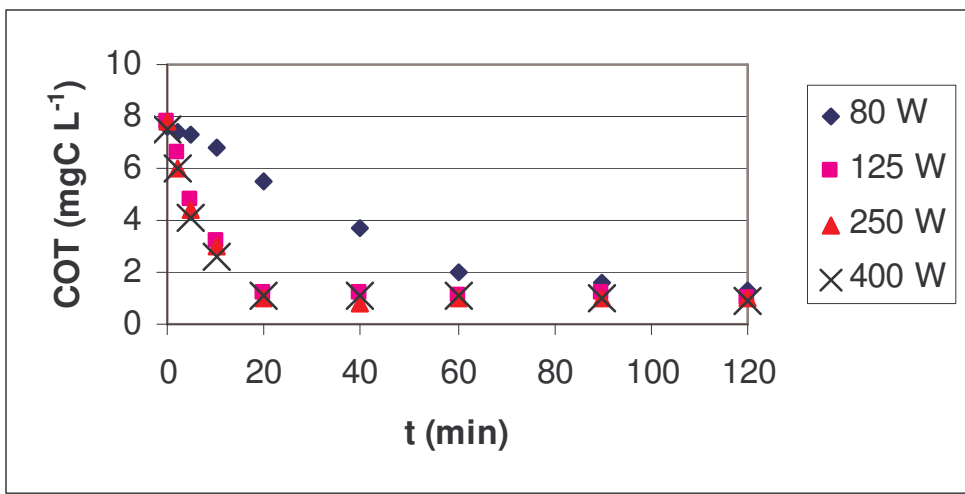

Figura 29 - Remoção de matéria orgânica durante tratamento de efluente E1 por sistema UV/ $\mathrm{H}_{2} \mathrm{O}_{2}$, para diferentes potências de lâmpadas. Experimentos BE1-13, BE1-14, BE1-15 e BE1-16, cujas condições experimentais estão apresentadas na Tabela 16. $\left(\mathrm{COT}_{0}=7,7 \mathrm{mgC} \mathrm{L}^{-1}, \mathrm{a}=9, \mathrm{~T}=30^{\circ} \mathrm{C}\right)$. 


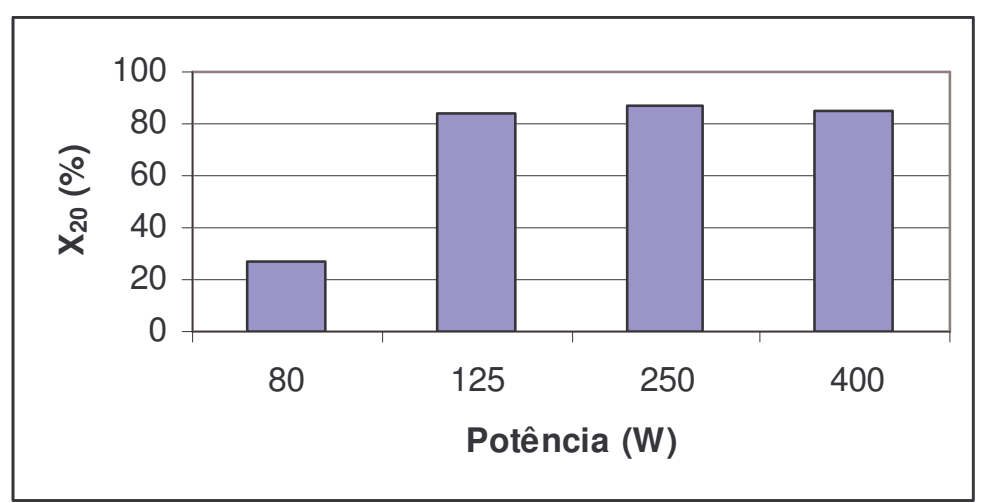

Figura 30 - Remoção de COT após 20 minutos de reação $\left(\mathrm{X}_{20}\right)$ versus Potência da lâmpada para efluente E1. Experimentos BE1-13, BE1-14, BE1-15 e BE1-16.

Na Figura 29 e Figura 30 observa-se que, para o efluente E1, quanto maior a potência elétrica da lâmpada maior o percentual de remoção de carbono orgânico total. No entanto, a partir da potência $125 \mathrm{~W}$ não foi possível distinguir diferenças significativas ao longo da curva e no percentual de remoção final de COT. Observase que o percentual de remoção máxima ( $80 \%)$ ocorreu para as potências de 125 , 250 e 400W, nas quais provavelmente houve excesso de fótons para esta condição de relação $\alpha=9$, que é a dose de $\mathrm{H}_{2} \mathrm{O}_{2}$ em mg por mg de COT presente no efluente.

Assim sendo, o uso de lâmpada de potência de $125 \mathrm{~W}$, em detrimento das potências maiores, implica um excedente de fótons menor e, portanto economia de energia. Constatações semelhantes podem ser feitas para os demais efluentes.

Nos casos dos efluentes E1, E2 e E3, que contêm baixo teor de matéria orgânica, um menor tempo de reação, aproximadamente 20 minutos de reação, é requerido para alcançar níveis satisfatórios de remoção, como é possível observar nos gráficos, da Figura 29 a Figura 34.
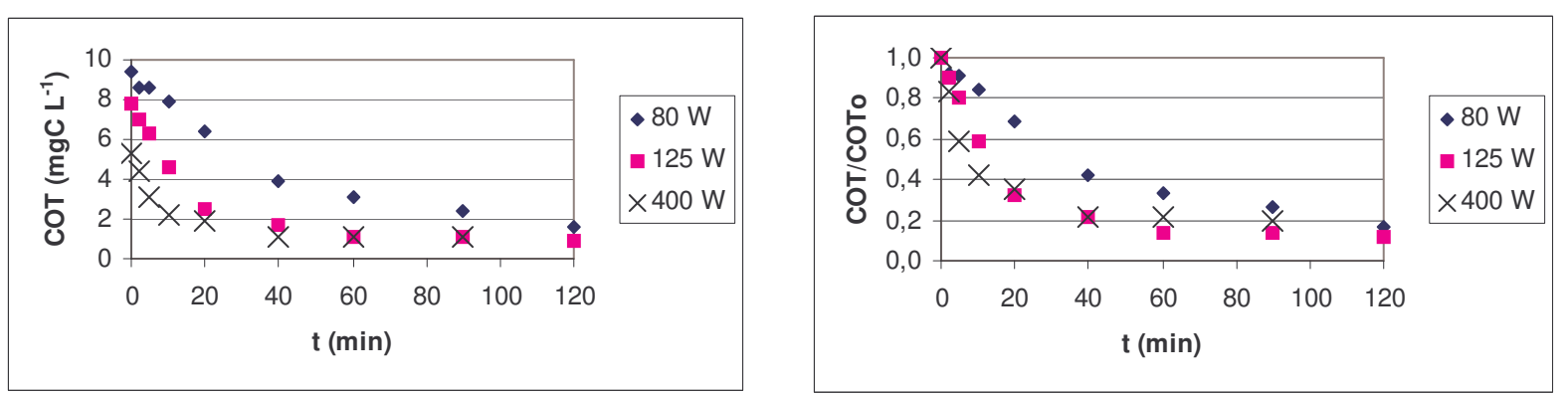

Figura 31 - Remoção de matéria orgânica durante tratamento de efluente E2 por sistema $U V / \mathrm{H}_{2} \mathrm{O}_{2}$, para diferentes potências de lâmpadas. Experimentos BE2-3, BE2-8 e BE2-15, cujas condições experimentais estão apresentadas na Tabela $17\left(\alpha=5, T=30^{\circ} \mathrm{C}\right)$. Os dados foram normalizados (figura à direita) devido às diferenças no $\mathrm{COT}_{0}$. 


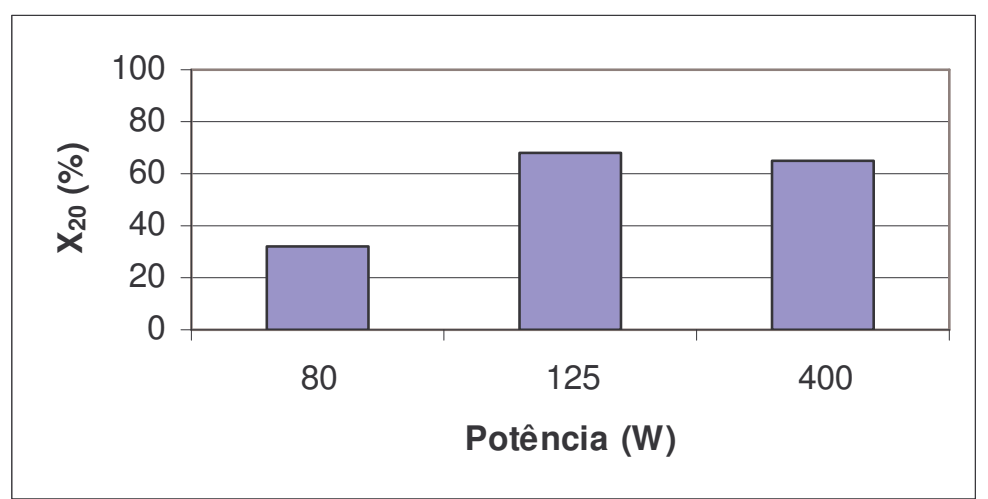

Figura 32 - Remoção de COT após 20 minutos de reação $\left(X_{20}\right)$ versus Potência da lâmpada para efluente E2. Experimentos BE2-3, BE2-8 e BE2-15.
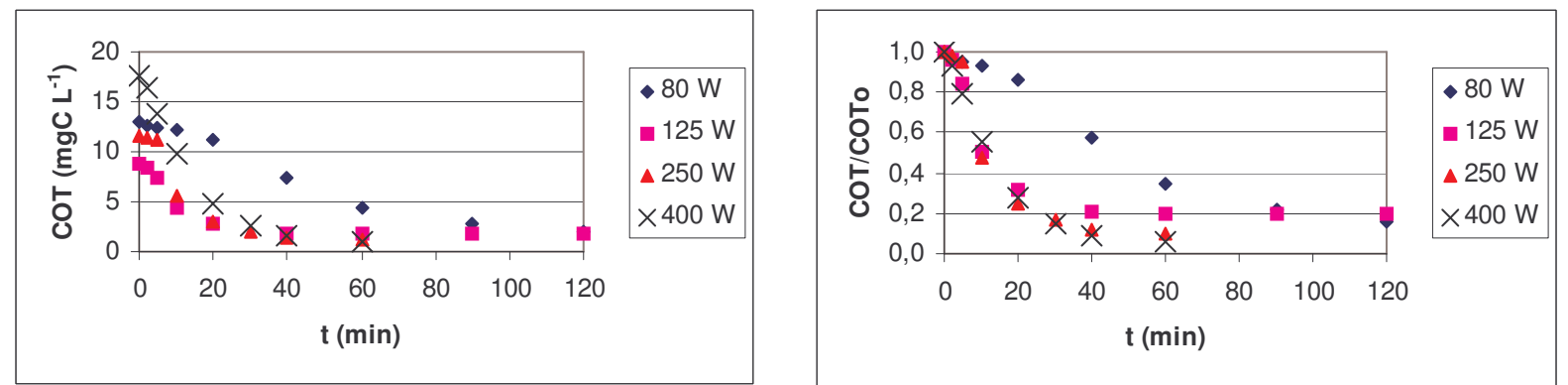

Figura 33 - Remoção de matéria orgânica durante tratamento de efluente E3 por sistema $U V / \mathrm{H}_{2} \mathrm{O}_{2}$, para diferentes potências de lâmpadas. Experimentos BE3-2, BE3-6, BE3-12 e BE3-17 cujas condições experimentais estão apresentadas na Tabela $18\left(\alpha \approx 7, T=30^{\circ} \mathrm{C}\right)$. Os dados foram normalizados (figura à direita) devido às diferenças no COTo.

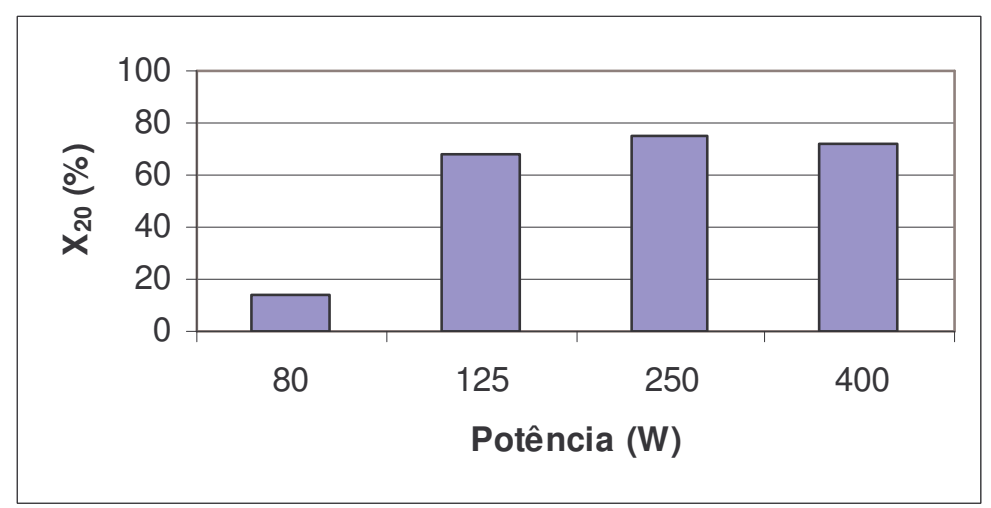

Figura 34 - Remoção de COT após 20 minutos de reação $\left(\mathrm{X}_{20}\right)$ versus Potência da lâmpada para efluente E3. Experimentos BE3-2, BE3-6, BE3-12 e BE3-17.

No entanto, para o caso do efluente E4 (Figura 36), de alto teor de matéria inicial, maiores tempos de reação são necessários, em torno de 80 minutos, para atingir níveis satisfatórios de remoção de COT. Algumas hipóteses para explicar este fato são: (1) parte da quantidade de fótons disponível no sistema é absorvida pela matéria orgânica presente em maior concentração, reduzindo a quantidade de fótons disponível; (2) natureza distinta de composição dos efluentes, o que pode resultar em caminhos de reação diferentes; (3) tempos maiores são requeridos em função da 
maior concentração de carbono orgânico, não tendo relação com a taxa de absorção de luz.
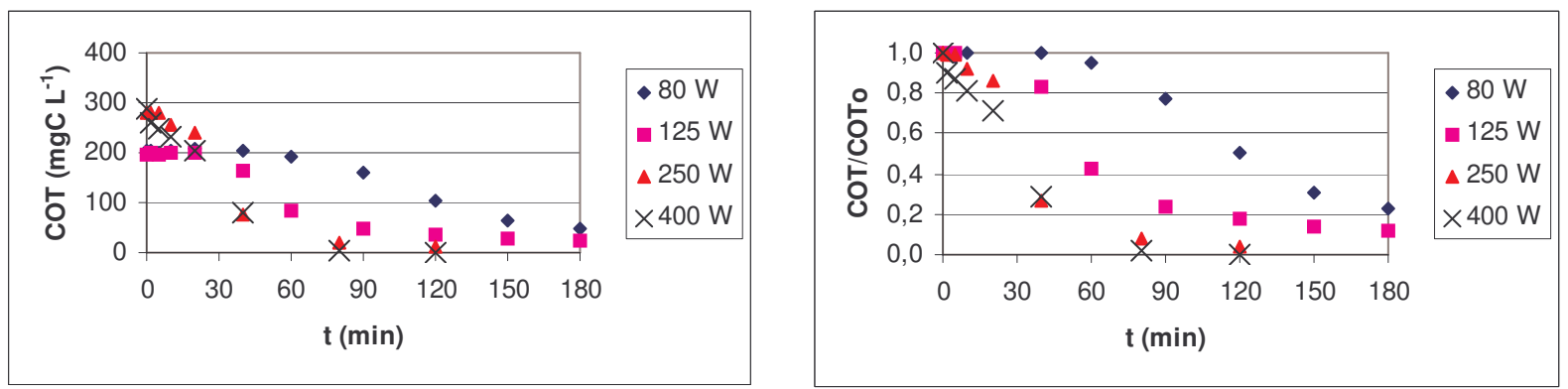

Figura 35 - Remoção de matéria orgânica durante tratamento de efluente $E 4$ por sistema $U V / \mathrm{H}_{2} \mathrm{O}_{2}$, para diferentes potências de lâmpadas. Experimentos BE4-1, BE4-5, BE4-12 e BE4-15 cujas condições experimentais estão apresentadas na Tabela $19\left(\alpha=9, T=30^{\circ} \mathrm{C}\right)$. Os dados foram normalizados (figura à direita) devido às diferenças no $\mathrm{COT}_{0}$.

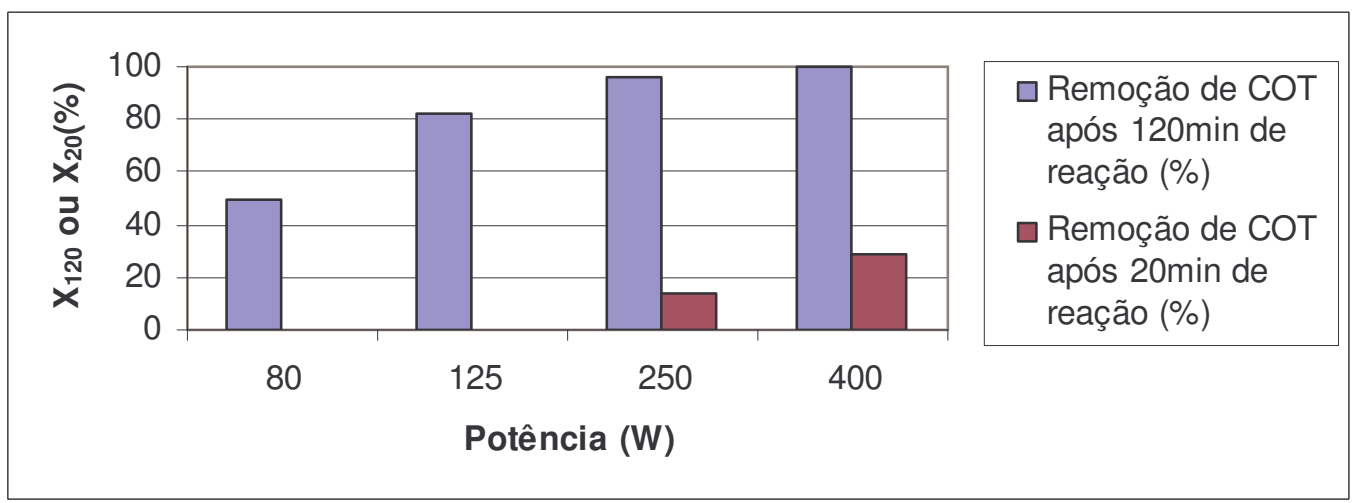

Figura 36 - Remoção de COT após 120 (20) minutos de reação $\left(\mathrm{X}_{120}\right.$ ou $\left.\mathrm{X}_{20}\right)$ versus Potência da lâmpada para efluente E4. Experimentos BE4-1, BE4-5, BE4-12 e BE4-15.

A Figura 37 apresenta em resumo a comparação de porcentagem de remoção de COT para os diferentes efluentes em função da potência da lâmpada.

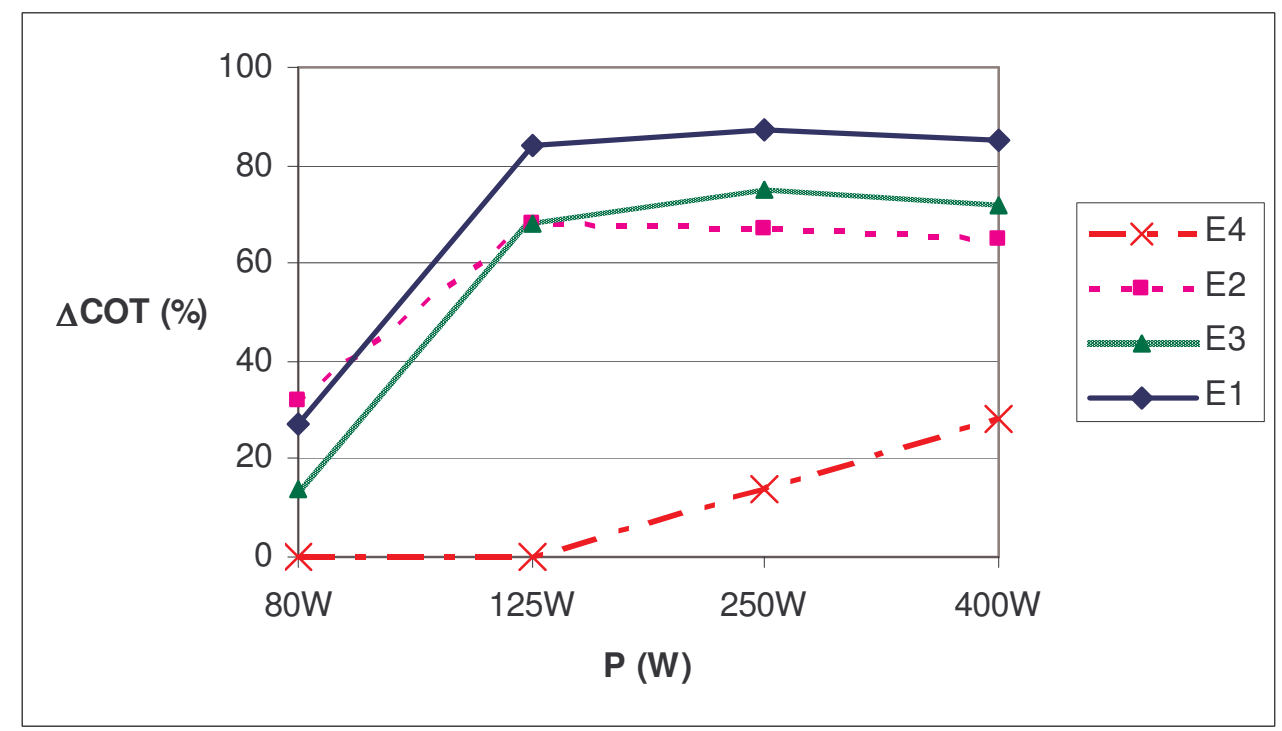

Figura 37 - Comparação de porcentagem de remoção de COT em função dos efluentes e da potência da lâmpada. Tempo de reação: 20 minutos. $\mathrm{E} 1=7,7 \pm 0,2 \mathrm{mgC} \mathrm{L}^{-1}$; $\mathrm{E} 2=7,5 \pm 2,1 \mathrm{mgC} \mathrm{L}^{-1}$; E3 =12,8 $\pm 3,7 \mathrm{mgC} \mathrm{L}^{-1}$ e E4 = $254 \pm 51 \mathrm{mgC} \mathrm{L}^{-1}$. 
A actinometria é um método simples para medir a intensidade de radiação luminosa incidente no reator fotoquímico. O método permite determinar a taxa de incidência de fótons $\left(P_{0}\right)$ em um sistema de geometria específica e domínio espectral da radiação bem definido (BRAUN; MAURETTE; OLIVEROS, 1991). A Figura 38 mostra resultados de actinometria para o reator fotoquímico batelada deste trabalho, obtidos pela equipe do CESQ-LSCP/DEQ-EPUSP. O actinômetro utilizado foi solução de ferrioxalato de potássio.

O resultado apresentado confirma a observação anterior de que para potência de lâmpada maior que $250 \mathrm{~W}$ não há efeito significativo sobre a taxa de remoção de COT das amostras.

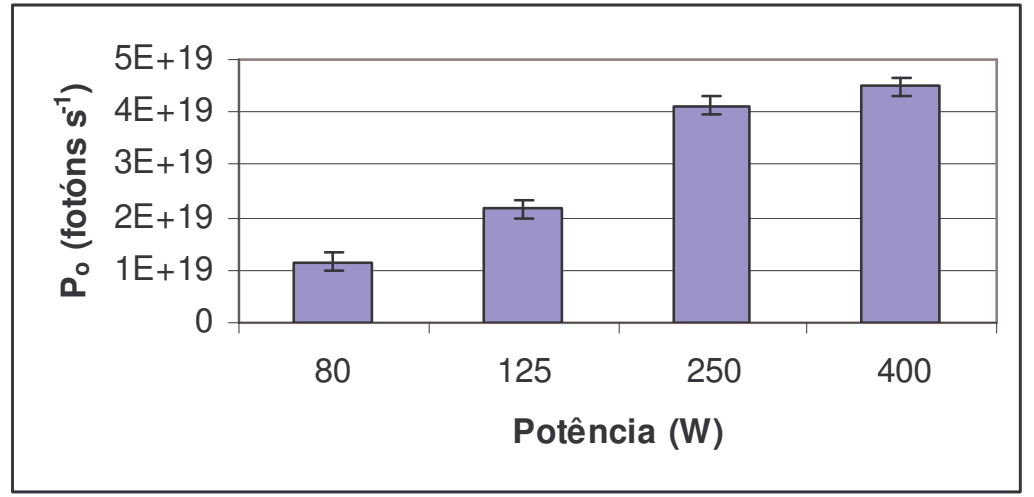

Figura 38 - Actinometria: taxa de incidência de fótons $P_{0}$ (fótons $s^{-1}$ ) em função da potência da lâmpada.

\subsubsection{Efeito da concentração de peróxido de hidrogênio}

Com a finalidade de analisar o efeito da concentração de $\mathrm{H}_{2} \mathrm{O}_{2}$ realizaram-se experimentos com vários níveis de concentração de $\mathrm{H}_{2} \mathrm{O}_{2}$. Devido à variação nos valores de COT inicial, a relação a foi utilizada como ferramenta para fins de comparação (em que a é razão mássica inicial de $\mathrm{H}_{2} \mathrm{O}_{2}$ e COT). $\mathrm{O}$ efeito foi avaliado na condição de excesso de luz, na qual o peróxido torna-se o reagente limitante e considerando a mesma condição de temperatura. Da Figura 39 à Figura 42 é apresentado o efeito da concentração de peróxido de hidrogênio ao longo do tempo de reação, para o caso de baixa (E1, E2 e E3) e alta (E4) teor de matéria orgânica.

No caso dos efluentes E1 e E2 (baixo teor de matéria orgânica), o efeito da quantidade de $\mathrm{H}_{2} \mathrm{O}_{2}$ foi avaliado para potência da lâmpada de $125 \mathrm{~W}$, a partir qual o aumento do valor não afeta de maneira significativa a degradação de COT, de 
acordo com os resultados mostrados no item anterior. Já para o efluente E3 (baixo teor de matéria orgânica), a condição na qual ao aumento da potência não afeta mais os resultados de remoção de COT ocorre para potências maiores ou iguais a $250 \mathrm{~W}$ e por isso o efeito da quantidade de $\mathrm{H}_{2} \mathrm{O}_{2}$ foi estudado para potência da lâmpada de 250W. Para o efluente E4 (alto teor de matéria), a saturação de luz foi atingida para a potência de $400 \mathrm{~W}$.

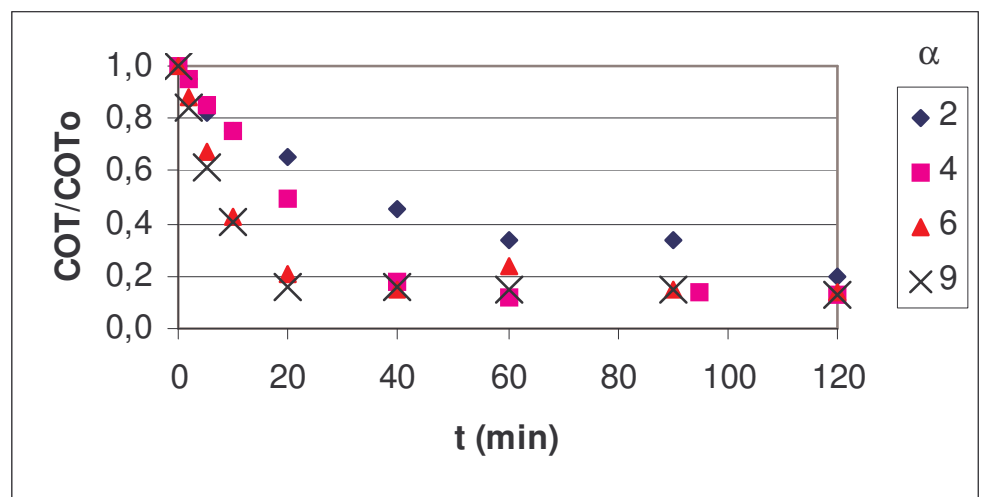

Figura 39 - Curvas de remoção de matéria orgânica no tratamento de efluente E1 por sistema $\mathrm{UV} / \mathrm{H}_{2} \mathrm{O}_{2}$, mostrando o efeito da concentração $\mathrm{H}_{2} \mathrm{O}_{2}$ representada pela razão $\alpha$. Experimentos $\mathrm{BE} 1-$ 10, BE1-11, BE1-12 e BE1-13 cujas condições experimentais estão apresentadas na Tabela 16 $\left(\mathrm{P}=125 \mathrm{~W}, \mathrm{~T}=30^{\circ} \mathrm{C}\right)$. Os dados foram normalizados devido às diferenças no $\mathrm{COT}_{0}$.

$\mathrm{Na}$ Figura 39 nota-se que, para o efluente E1, quanto maior a quantidade de $\mathrm{H}_{2} \mathrm{O}_{2}$ adicionada ao sistema maior o efeito sobre a taxa inicial de reação. Para $\alpha$ maior que $6 \mathrm{mgH}_{2} \mathrm{O}_{2} / \mathrm{mgCOT}$, observa-se que a curva de degradação permanece constante a partir dos 20 minutos de reação, atingindo níveis de remoção de COT maiores que 80\%. Para a menor que $4 \mathrm{mgH}_{2} \mathrm{O}_{2} / \mathrm{mgCOT}$, a velocidade de degradação decresce, sendo necessários maiores tempos de reação para alcançar níveis de remoção semelhantes. Ao final da reação, após 120 minutos, para todos os casos os percentuais atingidos foram próximos ( $86 \%)$.

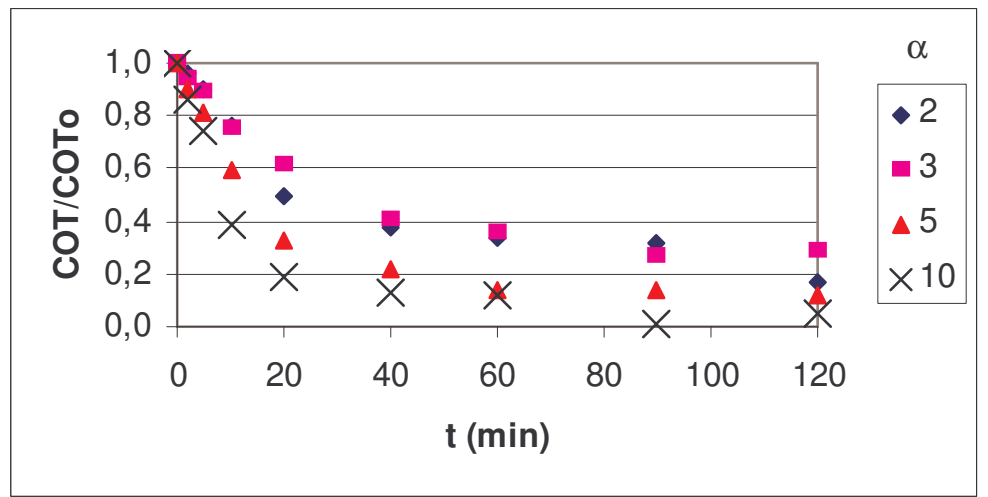

Figura 40 - Curvas de remoção de matéria orgânica durante tratamento de efluente E2 por sistema $\mathrm{UV} / \mathrm{H}_{2} \mathrm{O}_{2}$, mostrando o efeito da concentração $\mathrm{H}_{2} \mathrm{O}_{2}$ representada pela razão $\alpha$. Experimentos BE214, BE2-15, BE2-16 e BE2-17 cujas condições experimentais estão apresentadas na Tabela 17 $\left(\mathrm{P}=125 \mathrm{~W}, \mathrm{~T}=30^{\circ} \mathrm{C}\right)$. Os dados foram normalizados devido às diferenças no $\mathrm{COT}_{0}$. 
A mesma discussão vale para os resultados da Figura 40, pois quanto maior a quantidade de $\mathrm{H}_{2} \mathrm{O}_{2}$ maior o efeito sobre a taxa inicial. Contudo, para o efluente $\mathrm{E} 2 \mathrm{a}$ quantidade de $\mathrm{H}_{2} \mathrm{O}_{2}$ também influi mais significativamente sobre o percentual de remoção final. Para os menores níveis de $\mathrm{H}_{2} \mathrm{O}_{2}$ o percentual de remoção alcançada foi de $\sim 60 \%$ e para o maior nível foi de 95\%. Para $\alpha=2$ e $t=120 \mathrm{~min}$, o valor

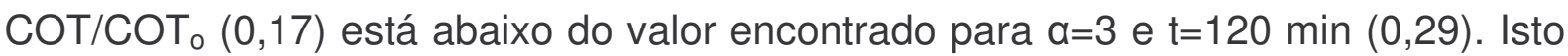
pode ser atribuído a erros de preparação das amostras e análises, uma vez que este ponto não está seguindo a tendência de estabilização no patamar conforme observado nas demais curvas. O comportamento das curvas de degradação para efluentes E1 e E2 é semelhante.

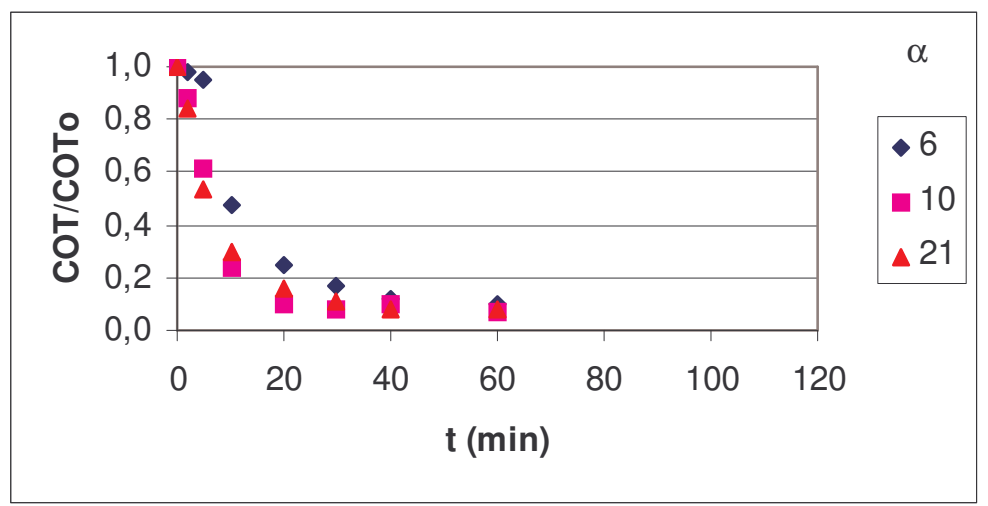

Figura 41 - Curvas de remoção de matéria orgânica durante tratamento de efluente E3 por sistema UV/ $\mathrm{H}_{2} \mathrm{O}_{2}$, mostrando o efeito da concentração $\mathrm{H}_{2} \mathrm{O}_{2}$ representada pela razão $\alpha$. Experimentos BE3-4, BE3-5 e BE3-6 cujas condições experimentais estão apresentadas na Tabela 18 ( $\left.P=250 \mathrm{~W}, \mathrm{~T}=30^{\circ} \mathrm{C}\right)$. Os dados foram normalizados devido às diferenças no $\mathrm{COT}_{0}$.

Para o efluente E3 0 efeito da concentração de $\mathrm{H}_{2} \mathrm{O}_{2}$ sobre a taxa de degradação é menor, mas ainda assim observam-se taxas de degradação iniciais menores para menores doses de $\mathrm{H}_{2} \mathrm{O}_{2}$. Neste caso, o efeito foi avaliado em 250W.

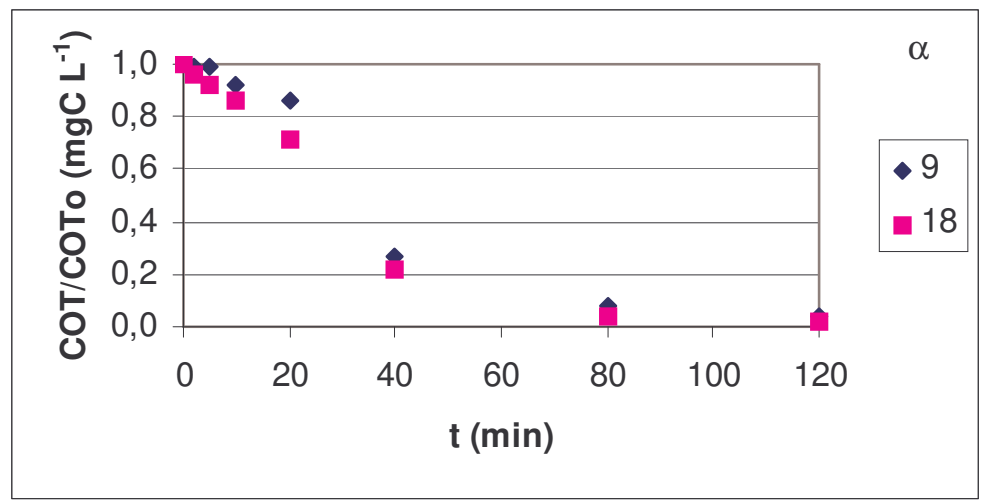

Figura 42 - Curvas de remoção de matéria orgânica durante tratamento de efluente E4 por sistema $\mathrm{UV} / \mathrm{H}_{2} \mathrm{O}_{2}$, mostrando o efeito da concentração $\mathrm{H}_{2} \mathrm{O}_{2}$ representada pela razão $\alpha$. Experimentos $\mathrm{BE} 4-5$ e BE4-6 cujas condições experimentais estão apresentadas na Tabela 19 ( $\left.P=250 \mathrm{~W}, \mathrm{~T}=30^{\circ} \mathrm{C}\right)$. Os dados foram normalizados devido às diferenças no $\mathrm{COT}_{0}$. 
Para o efluente E4 0 efeito da concentração de $\mathrm{H}_{2} \mathrm{O}_{2}$ sobre a taxa de degradação inicial (primeiros 20 minutos) no domínio experimental estudado, com doses de $\mathrm{H}_{2} \mathrm{O}_{2}$ de 9 e $18 \mathrm{mgH}_{2} \mathrm{O}_{2} / \mathrm{mg} \mathrm{COT}$, é maior em relação aos efluentes anteriores (E1, E2 e E3). A Figura 43 mostra o percentual de remoção $\left(X_{20}\right)$ e a taxa inicial de remoção de COT para os primeiros 20 minutos $\left(r_{20}\right)$. A Figura 44 mostra o percentual de remoção $\left(\mathrm{X}_{60}\right)$ e a taxa média de remoção de COT para os primeiros 60 minutos $\left(r_{60}\right)$.
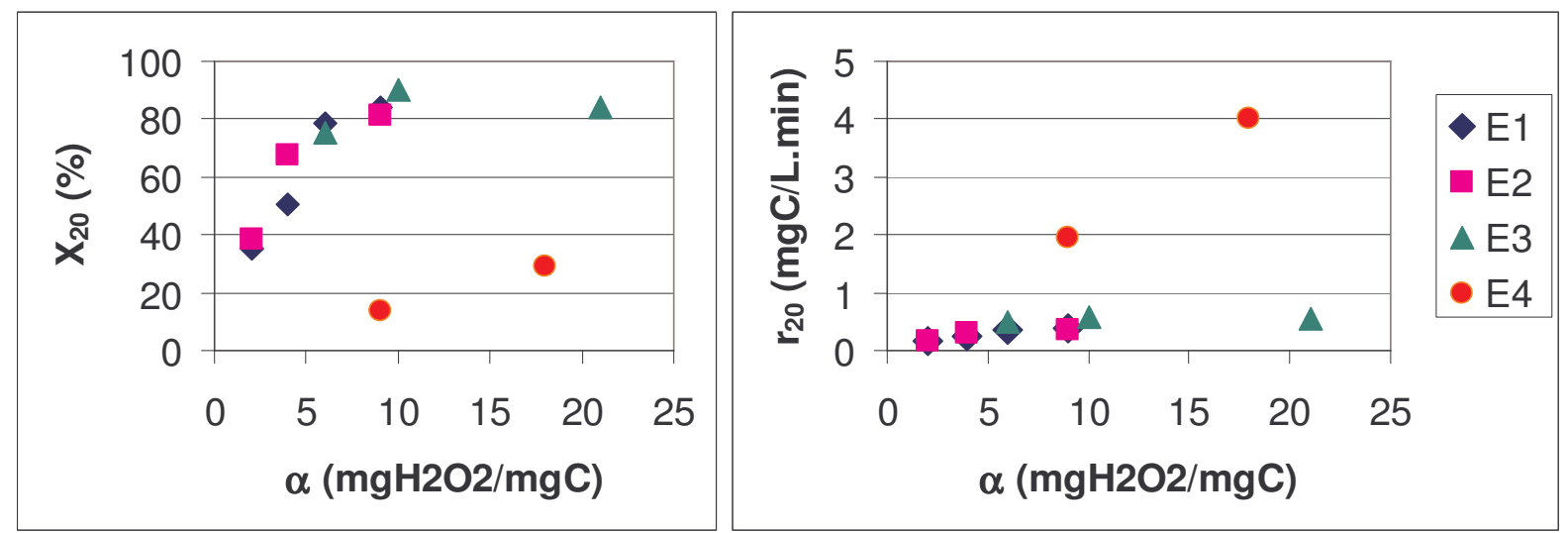

Figura 43 - Percentual de remoção de COT para $t=20 \min \left(\mathrm{X}_{20}\right)$ e taxa inicial de remoção para $\mathrm{t}=20$ min $\left(r_{20}\right)$ em função de dose de $\mathrm{H}_{2} \mathrm{O}_{2}(\alpha)$.
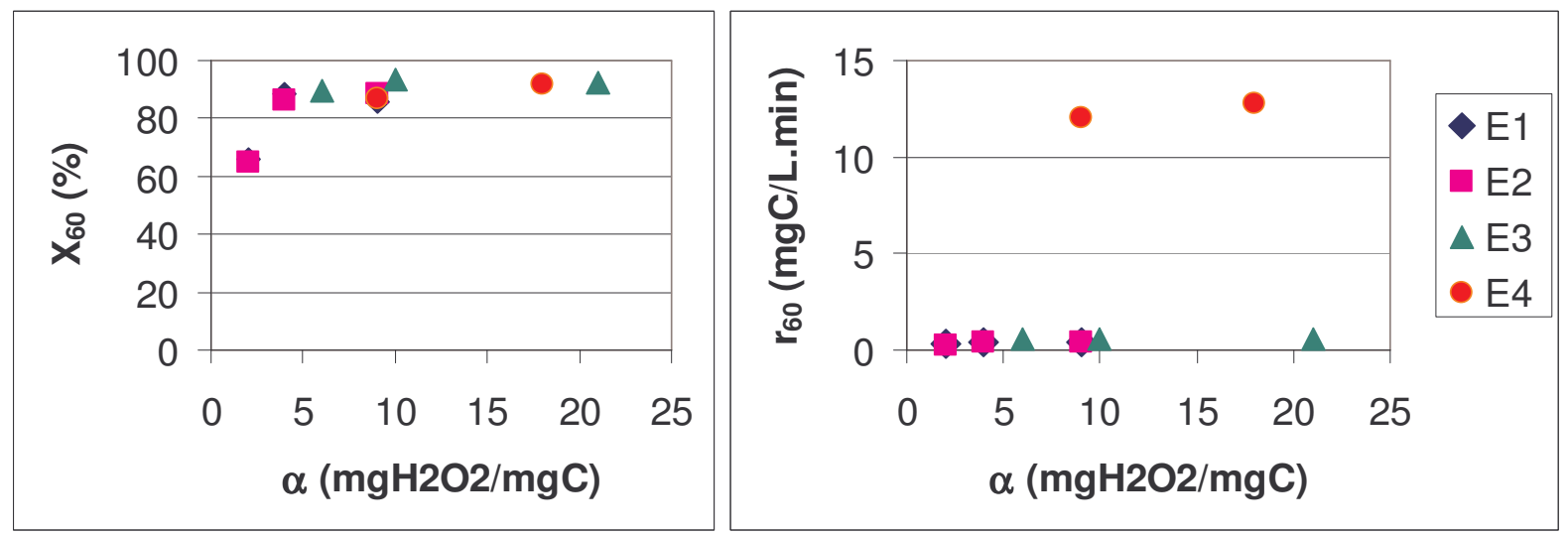

Figura 44 - Percentual de remoção de COT para $t=60$ min $\left(X_{60}\right)$ e taxa média de remoção para $\mathrm{t}=60 \mathrm{~min}\left(\mathrm{r}_{60}\right)$ em função de dose de $\mathrm{H}_{2} \mathrm{O}_{2}(\alpha)$.

Em todos os casos, o aumento da concentração de peróxido de hidrogênio no sistema resulta em maior degradação de matéria orgânica. A influência da variável $\mathrm{H}_{2} \mathrm{O}_{2}$ é positiva, pois variando-se a concentração de peróxido do nível menor para o maior, a taxa inicial de remoção aumenta (Figura 43). Apesar disso, considerando maiores tempos de remoção, a variável $\mathrm{H}_{2} \mathrm{O}_{2}$, passa a ter uma influência menor sobre o percentual de remoção de COT (Figura 44). Notam-se diferenças mais acentuadas na taxa inicial de remoção de COT para o caso de alto teor de matéria orgânica inicial. Com valores a em torno de 9 , o máximo percentual de remoção é atingido em todos os sistemas, não havendo necessidade de aumentar este valor, 
uma vez que seu efeito sobre o sistema é pouco relevante. A tendência de não haver melhoras nos resultados de oxidação a partir de uma determinada razão oxidante/contaminante é observada por alguns autores na oxidação de aromáticos (Sanz et al., 2002a). Como resultado do modelo cinético proposto na parte 2 REVISÃO BIBLIOGRÁFICA, a concentração de $\mathrm{HO}^{\circ}$ depende principalmente da concentração do oxidante $\mathrm{H}_{2} \mathrm{O}_{2}$. No entanto, parece existir uma concentração crítica de $\mathrm{H}_{2} \mathrm{O}_{2}$, acima da qual a concentração de $\mathrm{HO}^{\circ} \mathrm{e}$, portanto, as taxas de oxidação de contaminantes permanecem constantes, como mostrado na Figura 44. A análise pode indicar que o peróxido está em excesso para a maior que 9, por isso seu efeito não é significativo.

\subsubsection{Efeito da temperatura}

O efluente gerado na planta possui temperatura de cerca de $50^{\circ} \mathrm{C}$. Para avaliar o efeito da temperatura realizaram-se experimentos a 30 e $50^{\circ} \mathrm{C}$, com o objetivo de analisar se a eficiência do processo de tratamento fotoquímico seria prejudicada nas temperaturas mais elevadas e de manter as condições experimentais próximas das condições industriais. Os efeitos de temperatura foram avaliados considerando as mesmas condições de a e potência e encontram-se apresentados a partir da Figura 45 até Figura 48. Na Figura 46 (1), foi possível identificar um outlier (exp B2-6, t=60min), que possivelmente é devido à erros de coleta, podendo ser classificados como erro grosseiro. Observa-se que o sistema é pouco sensível à temperatura nas condições experimentais apresentadas. Este fato é uma das características das reações de primeira ordem (sistema de rápido percentual de remoção), no qual a energia de ativação é baixa. Os efeitos térmicos da energia útil fotoquimicamente são geralmente negligenciáveis (CASSANO et al., 1995). 


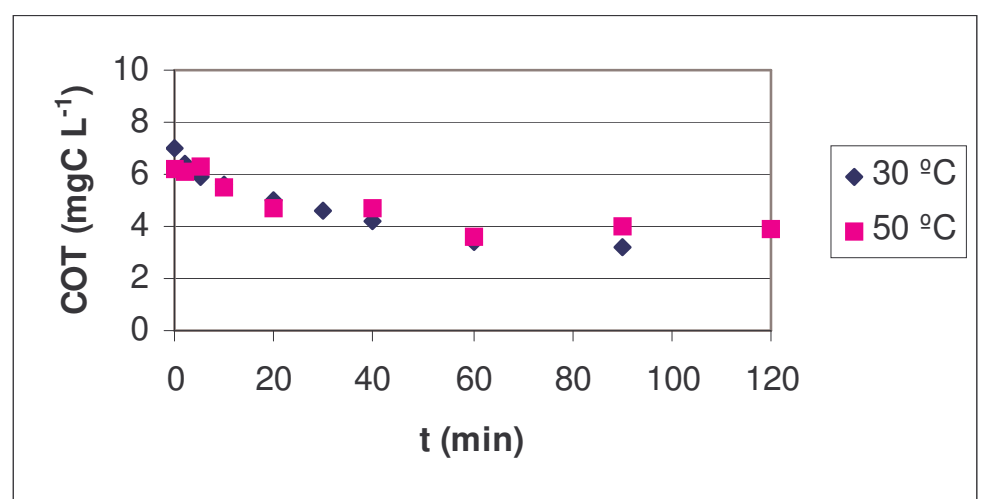

Figura 45 - Efeito da temperatura: efluente $\mathrm{E} 1, \mathrm{COT}_{0}=6,9 \mathrm{mgC} \mathrm{L}^{-1}, \mathrm{P}=80 \mathrm{~W},\left[\mathrm{H}_{2} \mathrm{O}_{2}\right]=0,8 \mathrm{mM}, \alpha=$ 4. Experimentos (»)BE1-4 e (匹) BE1-7, conforme Tabela 16.
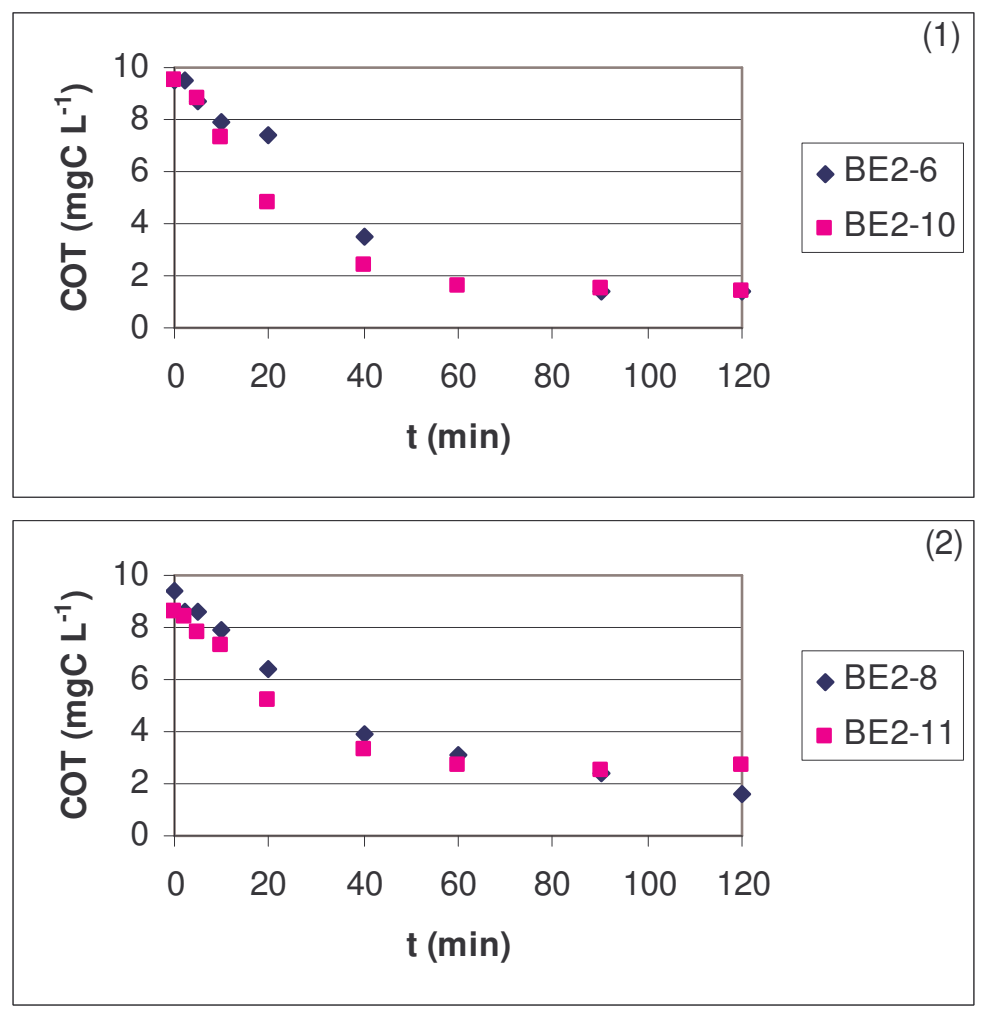

Figura 46 - Efeito da temperatura $(\star) 30^{\circ} \mathrm{C}$ e $(\varpi) 50^{\circ} \mathrm{C}$, efluente E2, COT $=9 \mathrm{mgC} \mathrm{L}^{-1}, \mathrm{P}=80 \mathrm{~W}$. Diagramas (1) $\alpha=8$, Diagramas (2) $\alpha=5$, conforme Tabela 17. 

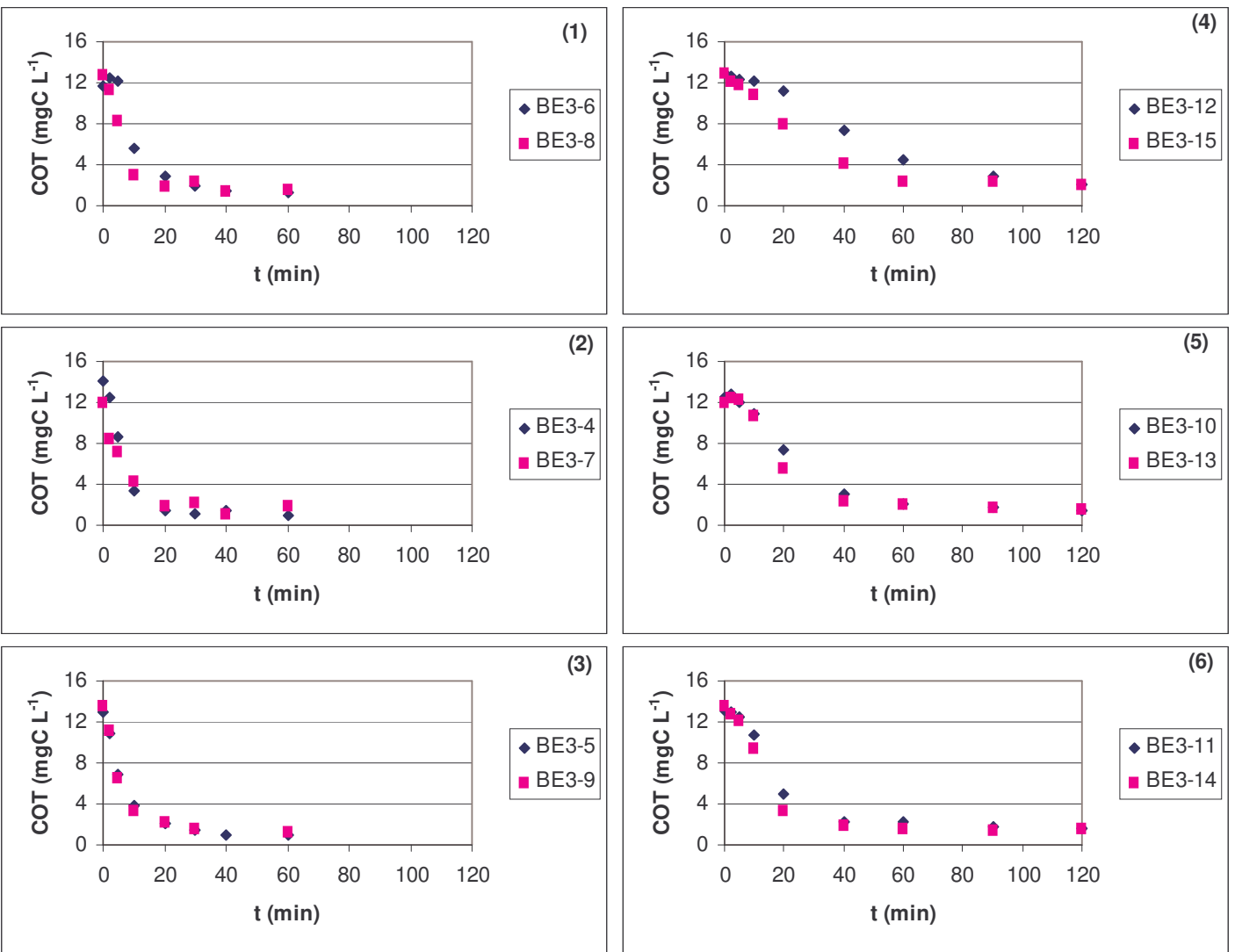

Figura 47 - Efeito da temperatura $(\bullet) 30^{\circ} \mathrm{C}$ e $\left(-50^{\circ} \mathrm{C}\right.$, efluente $\mathrm{E} 3, \mathrm{COT}_{0}=14 \mathrm{mgC} \mathrm{L}^{-1}$. Diagramas (1), (2) e (3) $P=250 \mathrm{~W}$; (4), (5) e (6) $P=80 \mathrm{~W}$. Relação $\alpha=6$ para diagramas (1) e (4), $\alpha=10$ para (2) e (5) e $\alpha=20$ para (3) e (6). Demais condições experimentais conforme Tabela 18.
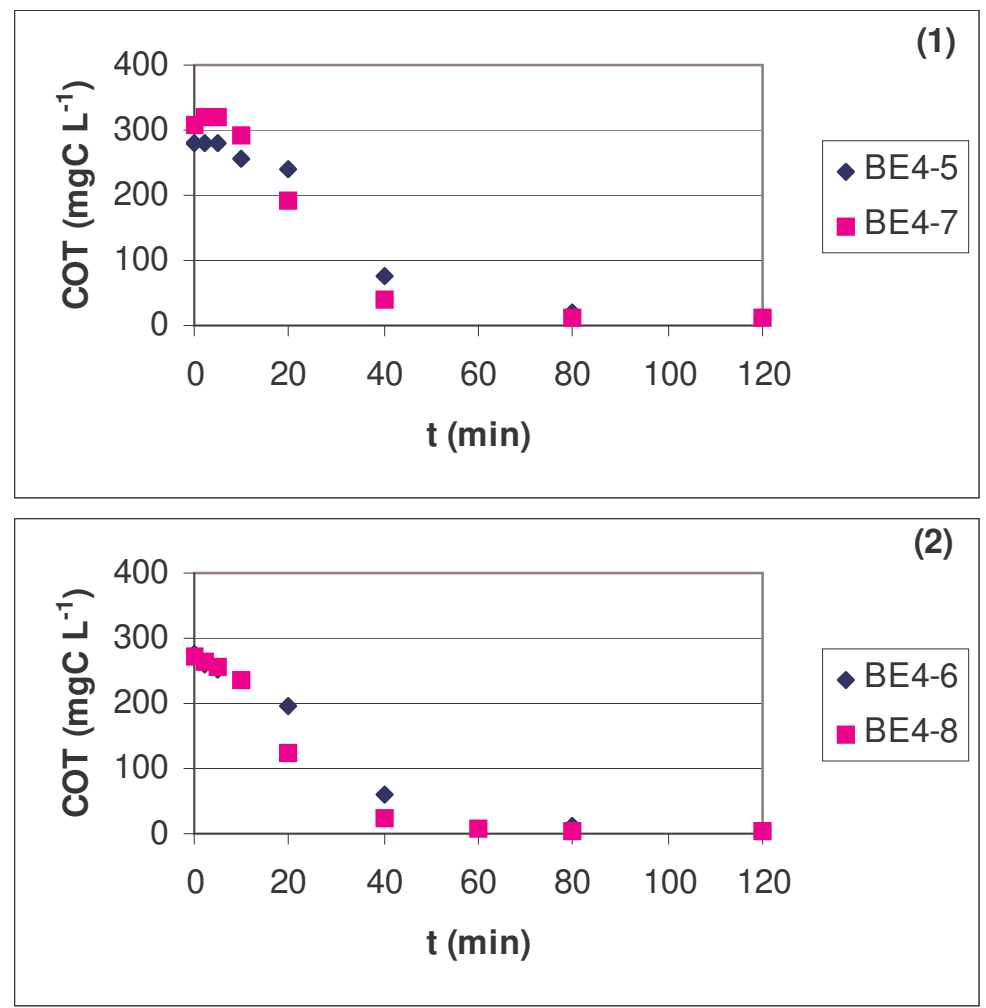

Figura 48 - Efeito da temperatura ( $\bullet) 30^{\circ} \mathrm{C} \mathrm{e} \mathrm{( \bullet )} 50^{\circ} \mathrm{C}$, efluente E4. Diagrama (1) $\mathrm{COT}_{0}=294 \mathrm{mgC} \mathrm{L}^{-1}$, $\mathrm{P}=250 \mathrm{~W}, \alpha=9$. Diagrama (2) $\mathrm{COT}_{0}=272 \mathrm{mgC} \mathrm{L}^{-1}, \mathrm{P}=250 \mathrm{~W}, \alpha=18$. Demais condições experimentais conforme Tabela 19. 


\subsubsection{Efeito do $\mathrm{pH}$}

Em todos os experimentos o pH do meio foi mantido livre, não havendo ajuste dessa variável ao longo da reação. Esta variável foi apenas monitorada. O resultado típico da variação do $\mathrm{pH}$, que representa grande parte dos ensaios realizados, é mostrado da Figura 49 até Figura 51.

Ao longo dos experimentos o valor do pH decrescia gradualmente a um nível mínimo, e então aumentava lentamente até um valor de $\mathrm{pH}$ mais baixo do que o valor inicial ao final do período de irradiação, como pode ser observado na Figura 49 e Figura 50. Esta variação é consistente com a formação de ácidos orgânicos e sua subseqüente remoção através das reações de oxidação. $\mathrm{O}$ pH mais baixo ao final da reação comparado com seu valor inicial pode ser atribuído ao $\mathrm{CO}_{2}$ gerado durante o processo ou à presença de ácidos orgânicos remanescentes ao final da reação (STEFAN; BOLTON, 1998).

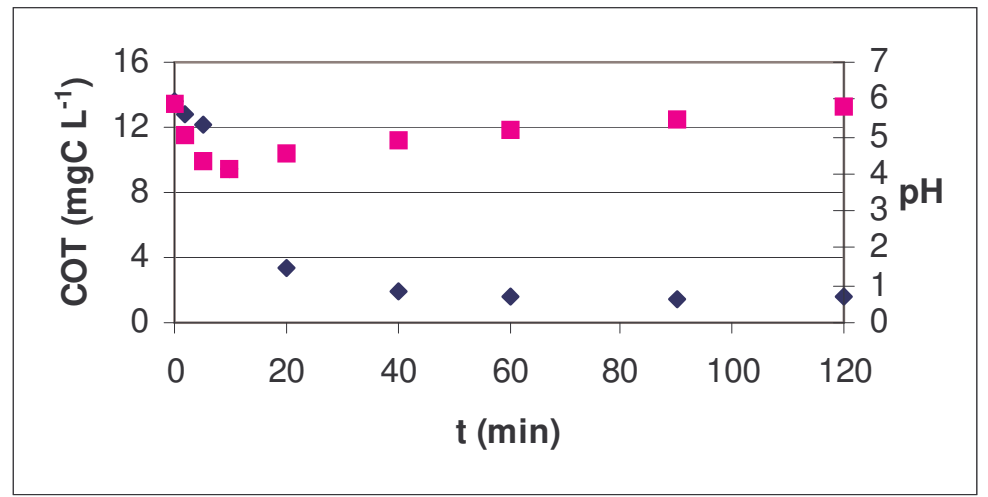

Figura $49-\mathrm{pH}$ versus tempo (min). Experimento B3-14, COTo $=14 \mathrm{mgC} \mathrm{L}-1,\left[\mathrm{H}_{2} \mathrm{O}_{2}\right] \mathrm{o}=8 \mathrm{mM}, \alpha=$ $20, \mathrm{P}=80 \mathrm{~W}$. (๘) $\mathrm{pH},(\bullet)$ COT.

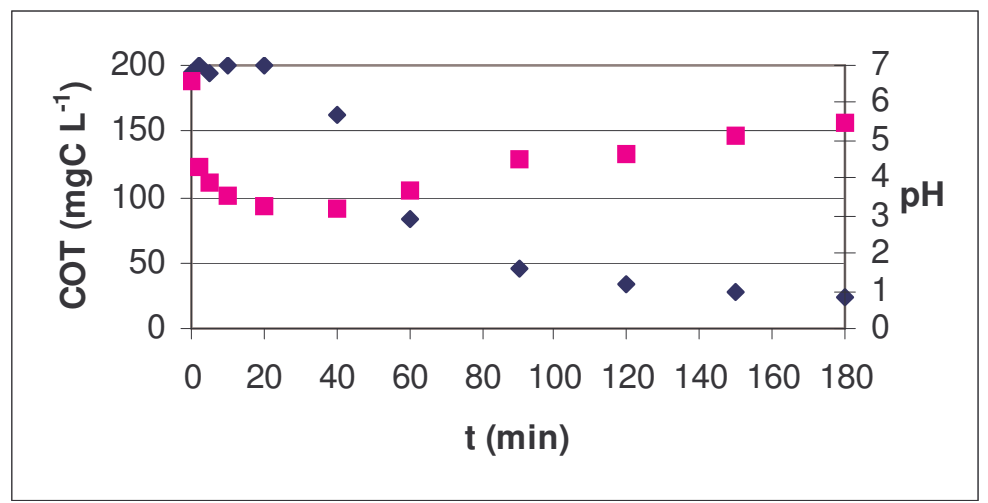

Figura $50-\mathrm{pH}$ versus tempo (min). Experimento B4-12, $\mathrm{COT}_{0}=195 \mathrm{mgC} \mathrm{L}^{-1},\left[\mathrm{H}_{2} \mathrm{O}_{2}\right]_{0}=53 \mathrm{mM}, \alpha=9$, $\mathrm{P}=125 \mathrm{~W}$. ( $\bullet \mathrm{pH},(\bullet)$ COT. 


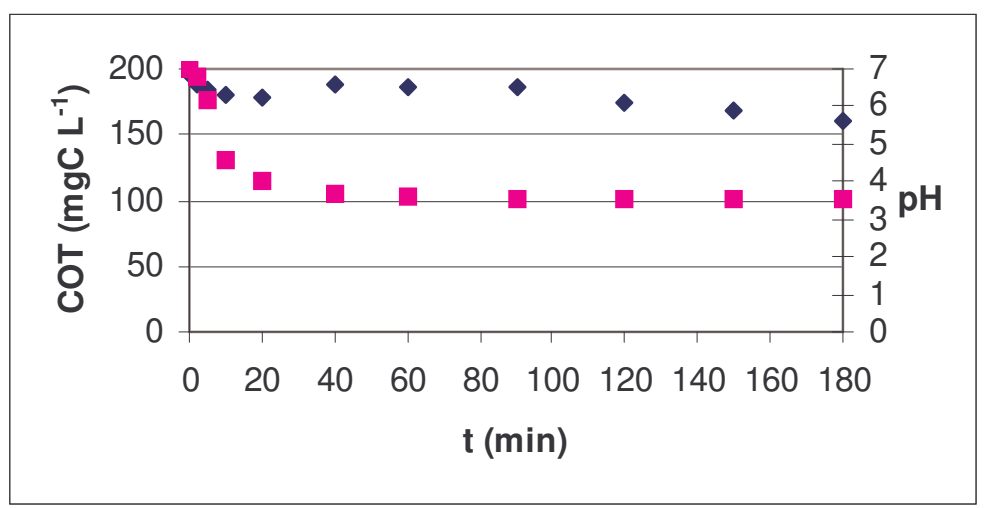

Figura $51-\mathrm{pH}$ versus tempo (min). Experimento $\mathrm{B} 4-13, \mathrm{COT}_{0}=197 \mathrm{mgC} \mathrm{L}^{-1},\left[\mathrm{H}_{2} \mathrm{O}_{2}\right]_{0}=13 \mathrm{mM}, \alpha=2$,

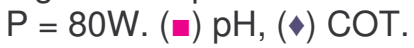

No caso do experimento apresentado na Figura 51, no qual pode-se observar que o nível de degradação foi pouco significativo, o pH diminuiu até um valor constante e não verificou-se o seu aumento como nos casos anteriores em que a degradação foi significativa. Isto pode indicar que, nas condições experimentais nas quais o experimento foi realizado, os ácidos orgânicos estavam sendo formados na mesma proporção em que estavam sendo consumidos a partir do instante no qual o $\mathrm{pH}$ passou a valor constante.

\subsubsection{Cálculo da constante aparente de remoção de COT}

Foi realizada uma tentativa de simulação dos resultados baseada no ajuste de uma constante aparente de remoção de COT, supondo-se que a reação global de oxidação segue cinética de primeira ordem com respeito à concentração de matéria orgânica (ACERO et al., 2004). Então a equação da taxa de reação pode ser expressa pela Eq.(31):

$$
-\frac{\mathrm{dCOT}}{\mathrm{dt}}=k_{o} \mathrm{COT}
$$

Em que $k_{o}$ é uma constante aparente de remoção de COT para a degradação química. Depois da integração da Eq.(31), a Eq.(32) é obtida:

$$
\ln \frac{\mathrm{COT}_{\mathrm{o}}}{\mathrm{COT}}=k_{o} \mathrm{t}
$$

Plotando-se o termo à esquerda versus tempo para os experimentos realizados, obtém-se uma linha reta com um bom ajuste para grande parte dos 
experimentos conduzidos. A Figura 52 apresenta resultados representativos do conjunto experimental para efluentes de baixo e alto COT inicial.

Nessa figura observa-se que, para os efluentes de baixo COT, é coerente considerar que a reação de oxidação segue cinética aparente de primeira ordem para intervalos de tempo iniciais. A partir de um determinado instante, a remoção de COT torna-se muito lenta. Para os efluentes com baixo COT, o intervalo de tempo no qual a reação de oxidação segue cinética aparente de primeira ordem, a partir do início do ensaio, foi de cerca de 60 minutos, para as condições experimentais com menores concentrações de $\mathrm{H}_{2} \mathrm{O}_{2}$ e baixos níveis de potência. Esse tempo, no entanto, foi de apenas cerca de 20 minutos para as maiores concentrações de $\mathrm{H}_{2} \mathrm{O}_{2}$ e altos níveis de potência.

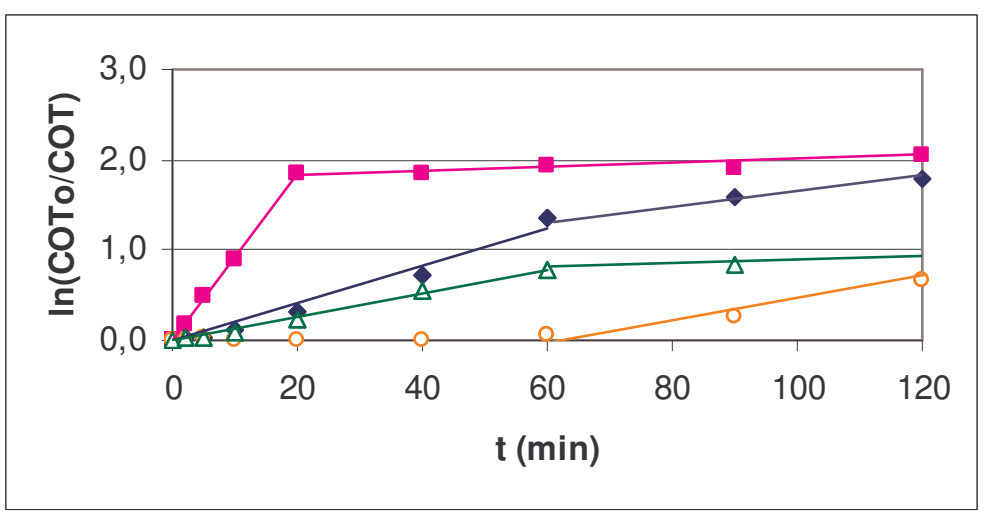

Figura 52 - Determinação da constante aparente da remoção de COT $\left(\mathrm{k}_{0}\right)$ durante o tratamento de efluente de baixo e alto COT. Efluente $\mathrm{E} 1$ (baixo COT): ( $\mathrm{a}$ ) $\mathrm{BE} 1-13 \mathrm{k}_{0}=0,09 \mathrm{~min}^{-1}, \mathrm{COT}_{0}=7,8 \mathrm{mgC} \mathrm{L}$ ${ }^{1}, \mathrm{P}=125 \mathrm{~W},\left[\mathrm{H}_{2} \mathrm{O}_{2}\right]=2,0 \mathrm{mM}, \alpha=9, \mathrm{~T}=30^{\circ} \mathrm{C} ;(\diamond) \mathrm{BE} 1-4 \mathrm{k}_{0}=0,02 \mathrm{~min}^{-1} \mathrm{COT}_{0}=7,6 \mathrm{mgC} \mathrm{L}^{-1}, \mathrm{P}=80 \mathrm{~W}$, $\left[\mathrm{H}_{2} \mathrm{O}_{2}\right]=2,0 \mathrm{mM}, \alpha=9, \mathrm{~T}=30^{\circ} \mathrm{C}$. Efluente $\mathrm{E} 1$ (baixo COT): $(\Delta) \mathrm{BE} 4-3 \mathrm{k}_{0}=0,01 \mathrm{~min}^{-1} \mathrm{COT}_{0}=336 \mathrm{mgC} \mathrm{L}^{-}$ ${ }^{1}, \mathrm{P}=400 \mathrm{~W},\left[\mathrm{H}_{2} \mathrm{O}_{2}\right]=41 \mathrm{mM}, \alpha=4, \mathrm{~T}=30^{\circ} \mathrm{C} ;(\mathrm{O}) \mathrm{BE} 4-15 \mathrm{k}_{0}=0,01 \mathrm{~min}^{-1} \mathrm{COT}_{0}=204 \mathrm{mgC} \mathrm{L}^{-1}, \mathrm{P}=80$ $W,\left[\mathrm{H}_{2} \mathrm{O}_{2}\right]=53 \mathrm{mM}, \alpha=9, \mathrm{~T}=30^{\circ} \mathrm{C}$.

O acréscimo da potência da lâmpada no sistema de $80 \mathrm{~W}$ para $125 \mathrm{~W}$ promoveu um aumento da constante de remoção de COT de 0,02 $\min ^{-1}$ no experimento $\mathrm{BE} 1-4$ para $0,09 \mathrm{~min}^{-1}$ no experimento $\mathrm{BE} 1-13$, ambos realizados na mesma concentração de $\mathrm{H}_{2} \mathrm{O}_{2}(2,0 \mathrm{mM})$. Para efluentes de alto COT, em alguns ensaios, cujas condições eram de menores concentrações de $\mathrm{H}_{2} \mathrm{O}_{2}$ e/ou baixas potências, o início da reação era caracterizado por um período no qual não houve degradação perceptível considerando os limites de precisão do equipamento de análise do COT. Esse período era mais curto, caso do experimento BE4-3, ou mais longo, caso do experimento BE4-15, dependendo das condições experimentais. Uma possível explicação para existência desse período: formação de intermediários que não resultam na queda de COT. Após esse período, a degradação iniciava-se conforme uma cinética aparente de primeira ordem até um instante no qual a taxa de 
remoção de COT caía bruscamente, permanecendo praticamente nula. Nota-se que para os intervalos em que foi atribuída à reação de degradação a cinética aparente de primeira ordem, os valores das constantes de remoção de COT para os experimentos com efluente de alto COT ( $k_{\circ}=0,01 \mathrm{~min}^{-1}$ para ambos os ensaios) foram menores em relação aos ensaios com efluente de baixo COT.

A descrição da cinética de reação usando modelos simples, como o de $1^{\text {a }}$ ordem, é parcialmente adequada para efluentes no domínio experimental estudado, pois o sistema tem comportamento complexo, o que limita a aplicação de modelos simples. É necessário outro tipo de abordagem, tal como será apresentado do item 4.1.4 (Modelagem por Redes Neurais).

\subsubsection{Viabilidade Econômica}

Os POAs, os quais envolvem a geração in-situ de oxidantes químicos altamente potentes tais como radical hidroxila, surgiram como uma importante classe de tecnologia para acelerar a oxidação e, portanto, a destruição de uma larga faixa de contaminantes orgânicos na água e no ar. Existe um número de fatores importantes na seleção de uma tecnologia de tratamento de efluente: custo, economia de escala, exigências ambientais, qualidade do efluente requerida, operação (manutenção, controle e segurança) e robustez (flexibilidade às mudanças). Embora todos estes fatores sejam importantes, os econômicos são freqüentemente essenciais. Uma análise econômica completa dos custos ( $p$. ex.: amortização, investimentos, instalação e custo de operação) de implementação de uma ampla faixa de tecnologias de tratamento representa um trabalho difícil e específico, uma vez que se trata de processos não convencionais, para os quais não há informações disponíveis com base em experiência acumulada. Um estudo de custo simplificado, ordem de grandeza, é apresentado a seguir. Neste cálculo considerou-se para o custo apenas o custo industrial da energia elétrica ( $R \$ 0,30$ / KWh, informado pela Suzano Petroquímica), visto que esta é a parcela mais significativa do custo total do processo. Adotando-se o custo do $\mathrm{H}_{2} \mathrm{O}_{2}$ a $50 \%$ como de $R \$ 1,95 / \mathrm{kg}$ (informado por fornecedores) e considerando a máxima dosagem de $\mathrm{H}_{2} \mathrm{O}_{2}$ aplicada neste trabalho $(141,2 \mathrm{mM}$, Tabela 15), então o custo por 1000 metros 
cúbicos de efluente tratado será de $R \$ 8,10$. A equação para o custo de energia é dada pela Eq.(33):

Custo $=($ Potência da lâmpada $) .($ custo de energia $) .(\Delta t / V)\left(R \$ / m^{3}\right)$

O custo do processo foi calculado para diferentes níveis de remoção de matéria orgânica, considerando as lâmpadas a vapor de mercúrio de média pressão: 80, 125, 250 e 400W. Para cada efluente, estes custos foram comparados com o custo de produção de água desmineralizada $\left(C A D, R \$ 7,40 / m^{3}\right.$, informado pela Suzano Petroquímica), a qual se quer substituir com o reúso. O reaproveitamento das correntes efluentes do processo tende a ser mais viável para os casos nos quais tais correntes sejam caracterizadas por baixos teores de COT, pois os compostos orgânicos neste tipo de efluente são mais facilmente removidos. Os resultados para todas as correntes de efluente estão apresentados da Figura 53 a Figura 56.

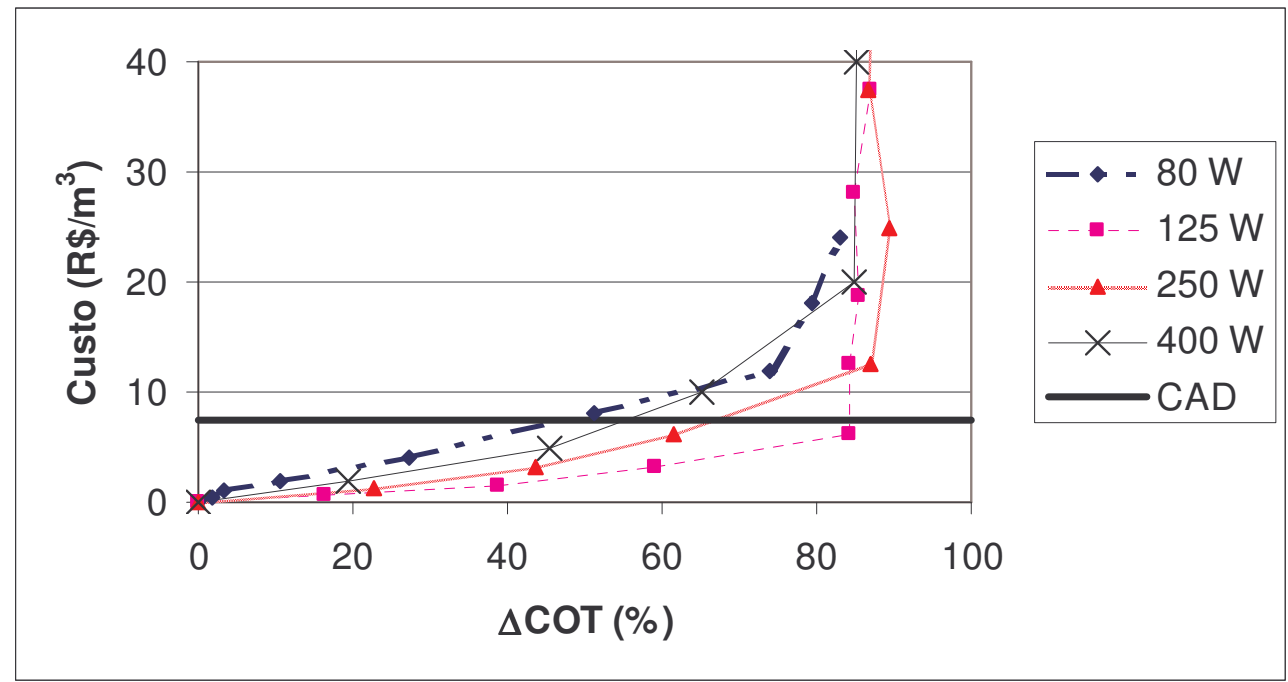

Figura 53 - Custo de tratamento por sistema $\mathrm{UV} \mathrm{H}_{2} \mathrm{O}_{2}$ versus $\triangle \mathrm{COT}$, efluente $\mathrm{E} 1, \mathrm{COT}_{0}=7,7 \mathrm{mgC} \mathrm{L}$ 1, $\alpha=9,\left[\mathrm{H}_{2} \mathrm{O}_{2}\right]_{0}=2,0 \mathrm{mM}, \mathrm{T}=30^{\circ} \mathrm{C}$. Experimentos: BE1-13, BE1-14, BE1-15 e BE1-16.

Para os efluentes com baixo COT (E1- Figura 53, E2 -Figura 54 e E3 - Figura 55) observa-se que remoções satisfatórias de matéria orgânica podem ser alcançadas com um custo menor do que o da água desmineralizada. $O$ uso de radiação com potência elétrica de $125 \mathrm{~W}$ favorece uma maior relação entre remoção de COT e custo de tratamento ( $\triangle \mathrm{COT} /$ custo). A avaliação do efluente tratado a fim de verificar se a água atende especificações para fins de reúso e o estudo da sua alocação dentro das unidades de processo fazem partem das próximas atividades do estudo, não incluídas neste trabalho. 


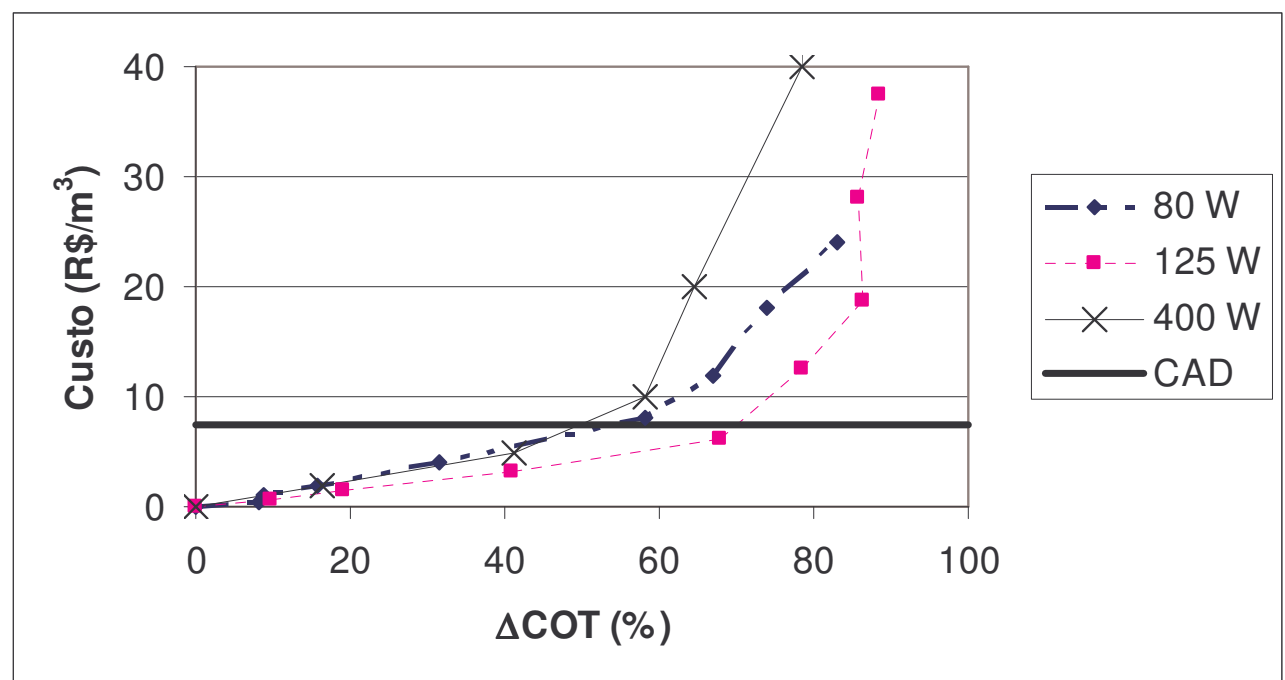

Figura 54 - Custo de tratamento por sistema $\mathrm{UV} / \mathrm{H}_{2} \mathrm{O}_{2}$ versus $\triangle \mathrm{COT}$, efluente $\mathrm{E} 2$, $C O \mathrm{~T}_{0}=5,3$ a 9,3 $\mathrm{mgC} \mathrm{L}{ }^{-1}, \alpha=4$ a $5,\left[\mathrm{H}_{2} \mathrm{O}_{2}\right]_{0}=0,8$ a 1,2 mM, T=30으. Experimentos: BE2-3, BE2-8 e BE2-15.

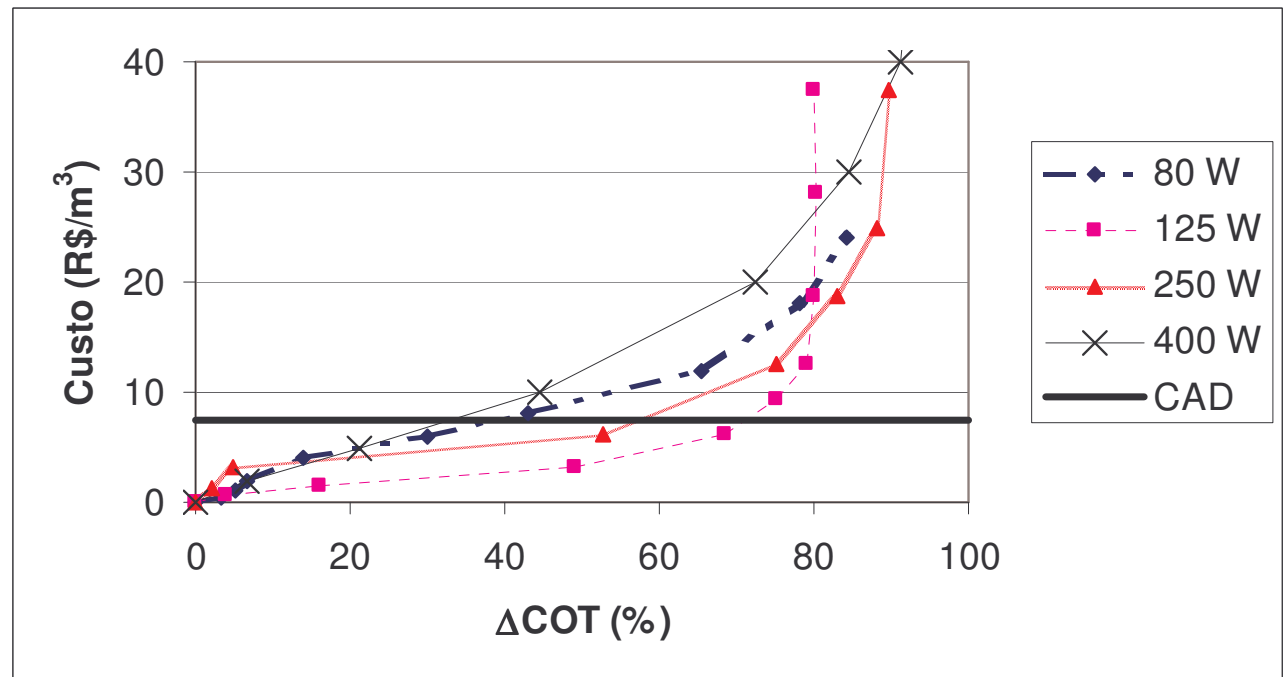

Figura 55 - Custo de tratamento por sistema $\mathrm{UV} / \mathrm{H}_{2} \mathrm{O}_{2}$ versus $\triangle \mathrm{COT}$, efluente $\mathrm{E} 3$, $\mathrm{COT}_{0}=8,8$ a 17,6 mgC L ${ }^{-1}, \alpha=6$ a 8, $\left[\mathrm{H}_{2} \mathrm{O}_{2}\right]_{0}=2,2$ a 3,3 mM, T=30으. Experimentos: BE3-2, BE3-6, BE3-12 e BE3-17.

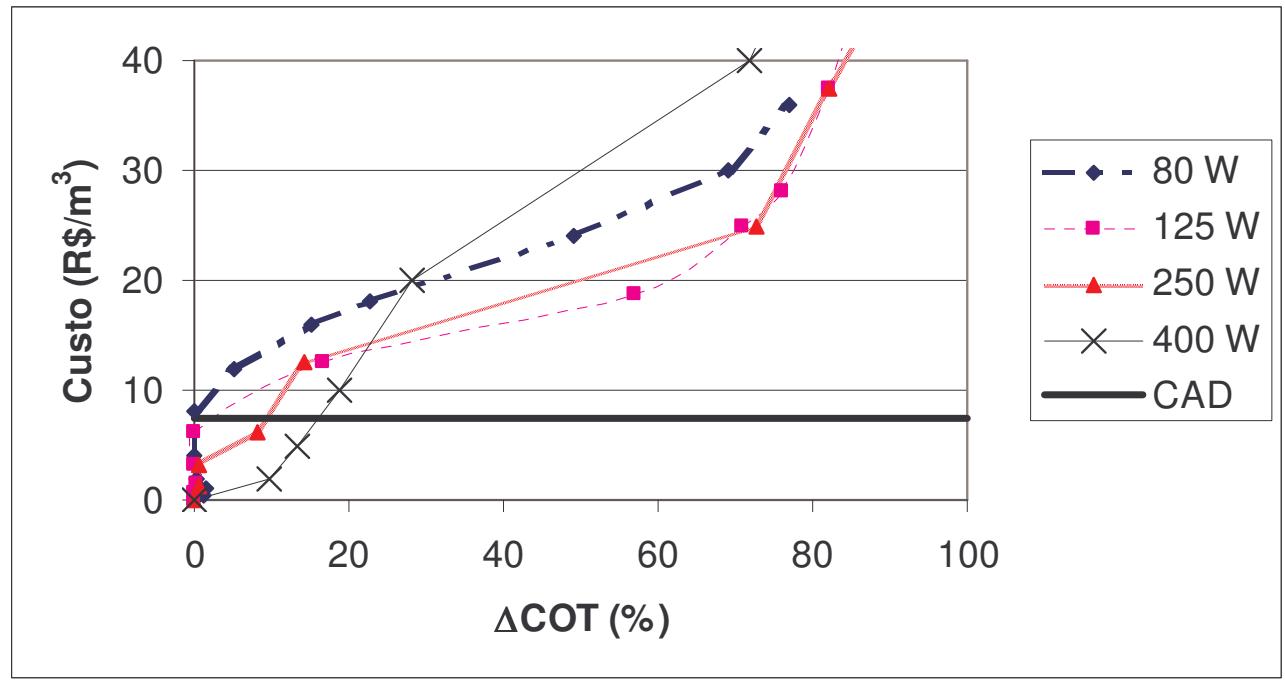

Figura 56 - Custo de tratamento por sistema $U V / \mathrm{H}_{2} \mathrm{O}_{2}$ versus $\triangle \mathrm{COT}$, efluente $\mathrm{E} 4, \mathrm{COT}_{0}=195$ a 287 $\mathrm{mgC} \mathrm{L}^{-1}, \alpha=9,\left[\mathrm{H}_{2} \mathrm{O}_{2}\right]_{0}=53$ a $76 \mathrm{mM}, \mathrm{T}=30$ e 50으. Experimentos: BE4-1, BE4-5, BE4-12 e BE4-15. 
No caso do efluente E4, (Figura 56), apesar do tratamento $\mathrm{UV} / \mathrm{H}_{2} \mathrm{O}_{2}$ ser viável tecnicamente, aparentemente não é viável economicamente, nas condições experimentais estudadas, devido ao alto COT. Altos teores de matéria orgânica possivelmente absorvem UV, prejudicando a geração de radicais hidroxila e, conseqüentemente, a sua ação sobre a taxa de remoção de COT. Venkatadri e Peters (1993) sugerem em seu trabalho que o sistema $U V / \mathrm{H}_{2} \mathrm{O}_{2}$ pode ser combinado com outros processos, tornando-se mais atrativo economicamente.

Os gráficos anteriores mostram claramente a diferença no comportamento cinético entre os efluentes de alto $\mathrm{COT}_{0}$ (efluente E4) e efluentes com baixo COT。 (E1, E2 e E3). A taxa de remoção de contaminantes é diretamente proporcional à quantidade de energia elétrica empregada para efluente com alto teor de matéria orgânica (BOLTON et al., 1995), sendo que a lâmpada de 400W proporciona as maiores remoções de COT. Para efluente com baixo teor de matéria orgânica, a lâmpada de potência 125W proporciona as maiores remoções de COT considerando o custo limite para aplicabilidade do sistema $U V / \mathrm{H}_{2} \mathrm{O}_{2}$ com a finalidade de reduzir a produção de água desmineralizada.

Claro que há outros fatores que deverão completar a análise de custo, no entanto esta análise preliminar permitiu obter informações para estabelecer metas para o estudo do tratamento fotoquímico contínuo e propor uma configuração possível para o reúso (Figura 57).

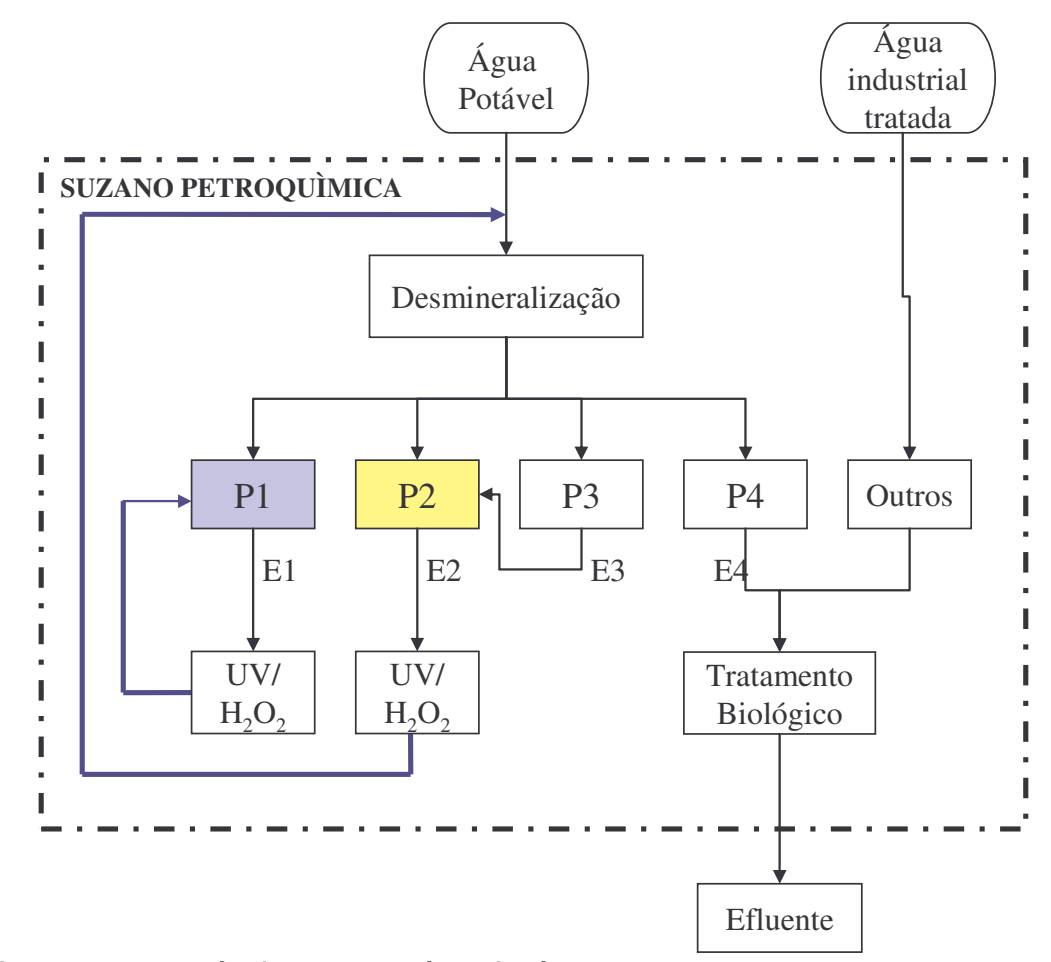

Figura 57 - Configuração possível para o reúso da água. 
O APÊNDICE C apresenta a planilha de estimativa de custos para três casos distintos, antes (cenário 1) e após (cenário 2) implantação de reúso de água de processo.

> CASO A: Reúso direto no próprio processo P1 e Reúso alimentando o processo de desmineralização, conforme Figura 57. O custo de tratamento fotoquímico (CT) foi fixado em $\mathrm{R} \$ 7,40 / \mathrm{m}^{3}$, cujo valor é igual ao custo de produção de água desmineralizada (CAD).

$>$ CASO B: Idem ao caso anterior, exceto pelo custo de tratamento (CT) fixado em $\mathrm{R} \$ 4,40 / \mathrm{m}^{3}$.

CASO C: Reúso direto nos próprios processos P1, P2 e P3. O custo de tratamento fotoquímico (CT) foi fixado em $\mathrm{R} \$ 7,40 / \mathrm{m}^{3}$.

Para os três casos, considerando o cenário 1 (antes da implantação de reúso de água de processo), o custo de captação e desmineralização de água para a vazão máxima é de $R \$ 359.211,58$ por ano. Soma-se a este valor o custo de descarte ( $R \$ 968,23)$, baseado na metodologia de cobrança do Comitê para Integração da Bacia Hidrográfica do Rio Paraíba do Sul - CEIVAP (Deliberações CEIVAP nº 008/01 e 015/02). Para caso A, haverá um prejuízo global de $36 \%$ deste valor com a implantação do reúso. Entretanto, uma economia de 54\% com o custo de captação e desmineralização (CAD) pode ser alcançada. Este valor representa uma parcela significativa quando se avalia a tendência de aumento do custo de captação de recursos hídrico.

O prejuízo obtido para o caso A pode sofrer decréscimo, quando o valor do custo de tratamento diminui, conforme apresentado no caso B (prejuízo global igual a $0 \%$, economia CAD igual a 54\%) ou quando houver uma realocação das correntes reusadas para o próprio processo (caso C: prejuízo global igual a 0\%, economia CAD igual a 90\%).

Deve-se ter em mente que o reúso da água resulta não somente em benefício econômico, mas também em benefício ambiental, diminuindo a descarga de poluentes e permitindo alcançar tanto a redução no consumo de água, quanto na quantidade de efluente gerado. 


\subsubsection{Modelagem por Redes Neurais}

Um modelo baseado em redes neurais artificiais foi desenvolvido com os dados experimentais obtidos no reator fotoquímico batelada em escala de bancada. O objetivo do modelo é descrever a evolução da concentração de COT ao longo do tempo de reação sob variadas condições operacionais e simular o comportamento do sistema de reação. A base de dados apresentada à rede consistiu de 60 experimentos, conforme apresentados da Tabela 16 até a Tabela 19. Os experimentos, cuja adição de $\mathrm{H}_{2} \mathrm{O}_{2}$ foi feita ao longo dos ensaios não foram apresentados à rede.

Os programas utilizados para preparação dos dados, bem como para ajuste e simulação de redes neurais, foram desenvolvidos no LSCP/DEQ-EPUSP (NASCIMENTO; GUARDANI, 1998).

Como o tempo também é uma variável de entrada, cada amostra retirada num determinado tempo em cada experimento é considerada uma observação experimental para utilização no ajuste do modelo de rede neural. Assim, os 60 experimentos corresponderam a uma base de dados de 594 observações experimentais.

\subsubsection{Variáveis de entrada e saída para o modelo de redes neurais.}

Três modelos de rede neural foram desenvolvidos. O primeiro modelo ( $M-1)$ abrange os dados de remoção de COT para todos os níveis de concentração de carbono orgânico inicial (COTo), ou seja, para alto COT。 (efluente E4) e baixo COT。 (demais efluentes). O segundo (M-2) e terceiro (M-3) modelos englobam cada um os dados dos experimentos realizados com efluentes de baixo e alto $\mathrm{COT}_{0}$, respectivamente. As variáveis de entrada para os três modelos são: $x_{1}$, tempo de reação $t(\min ) ; x_{2}$, concentração inicial de peróxido de hidrogênio $\left[\mathrm{H}_{2} \mathrm{O}_{2}\right]_{\circ}(\mathrm{mM}) ; \mathrm{x}_{3}$, potência da lâmpada $\mathrm{P}(\mathrm{W}) ; \mathrm{x}_{4}$, temperatura de reação $\mathrm{T}\left({ }^{\circ} \mathrm{C}\right)$; e $\mathrm{x}_{5}, \mathrm{COT}_{0}\left(\mathrm{mgC} \mathrm{L}^{-1}\right)$. $A$ concentração de COT ao longo do tempo - $\operatorname{COT}(t)$ - é a variável de saída $y_{1}$. A faixa de variação para as variáveis de entrada e saída é dada na Tabela 20. Todas as variáveis foram normalizadas na faixa entre 0,1 e 0,9 . 
Tabela 20 -Valores mínimos e máximos para as variáveis de entrada e saída

\begin{tabular}{|c|c|c|c|c|c|c|c|}
\hline Modelos & Variáveis & $\begin{array}{c}t \\
(\min ) \\
x_{1}\end{array}$ & $\begin{array}{c}{\left[\mathrm{H}_{2} \mathrm{O}_{2}\right]_{\circ}} \\
(\mathrm{mM}) \\
\mathrm{x}_{3}\end{array}$ & $\begin{array}{c}\text { Potência } \\
\text { (W) } \\
x_{3}\end{array}$ & $\begin{array}{c} \\
(\stackrel{T}{ }) \\
x_{4}\end{array}$ & $\begin{array}{c}\text { COTo } \\
\left(\mathrm{mgC} \mathrm{L}^{-1}\right) \\
\mathrm{X}_{5}\end{array}$ & $\begin{array}{c}\operatorname{COT}(\mathrm{t}) \\
\left(\mathrm{mgC} \mathrm{L}^{-1}\right) \\
\mathrm{y}_{1}\end{array}$ \\
\hline \multirow{2}{*}{$M-1$} & Mínimo & 0 & 0,4 & 80 & 30 & 3,6 & 0,4 \\
\hline & Máximo & 180 & 141,2 & 400 & 50 & 336,4 & 356 \\
\hline \multirow{2}{*}{ M-2 } & Mínimo & 0 & 0,4 & 80 & 30 & 3,6 & 0,4 \\
\hline & Máximo & 120 & 8,0 & 400 & 50 & 17,6 & 17,6 \\
\hline \multirow{2}{*}{$M-3$} & Mínimo & 0 & 13,0 & 80 & 30 & 193 & 3,0 \\
\hline & Máximo & 180 & 141,2 & 400 & 50 & 336,4 & 356 \\
\hline
\end{tabular}

A rede neural utilizada no trabalho foi de sentido único ("feed-forward"), com três camadas: a de entrada de dados, a oculta e a de saída. A Figura 58 mostra a rede utilizada e as variáveis de entrada e saída.

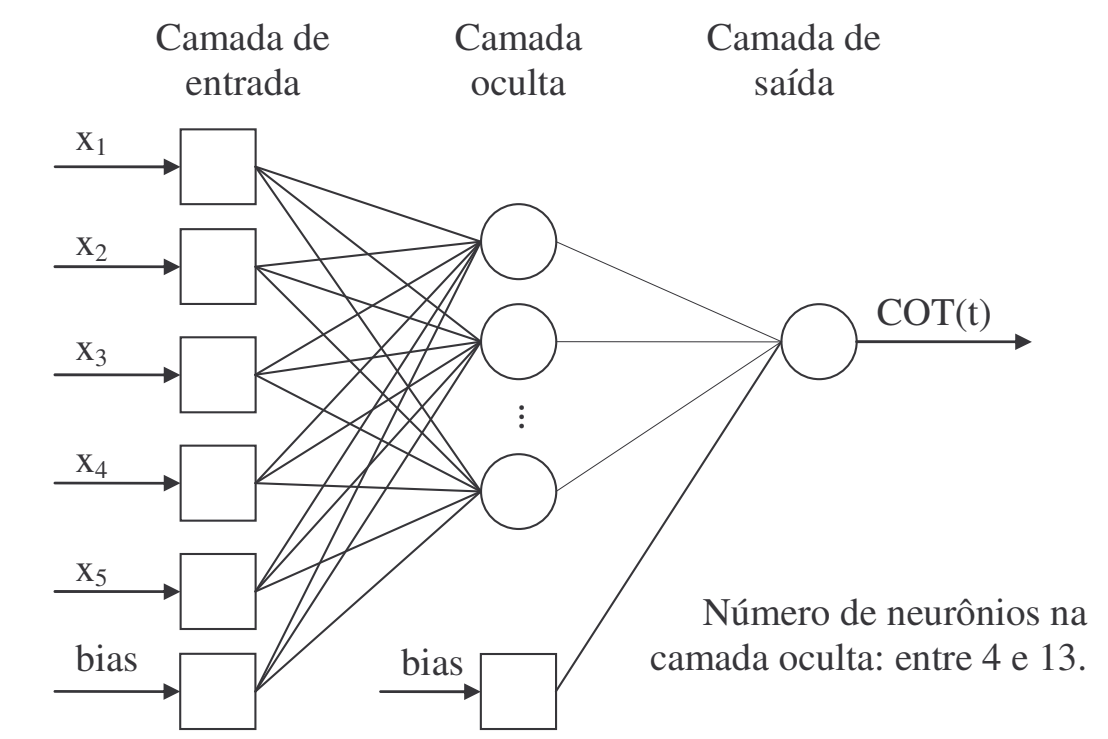

Figura 58 - Rede neural utilizada na modelagem e variáveis de entrada e saída.

\subsubsection{Análise dos dados}

Uma etapa prévia de escolha de dados é essencial para a qualidade e confiabilidade dos modelos de rede neural. Portanto, dados anômalos e dados contendo erros grosseiros devem ser removidos com a finalidade de não afetar o ajuste do modelo. Com base nesse critério, os experimentos retirados da base de dados foram:

experimentos cuja adição de peróxido não foi feita apenas no início: BE1-1, BE1-2, BE2-1, BE2-2, BE3-1, BE4-1 e BE4-2;

> BE3-3 (não possui coerência com os outros experimentos); 
> conjunto independente escolhido aleatoriamente para validação dos modelos através de simulação: BE1-8, BE2-14, BE2-16, BE2-18, e BE3-15.

Após a primeira etapa de filtração e reconciliação dos dados, o conjunto de dados M-1 foi alimentado à rede neural com três camadas, sendo o ajuste baseado no algoritmo retropropagação para implementação dos pesos. Os dados foram organizados em dois conjuntos, um de aprendizado (Learning Set, LS) e outro de teste (Test Set, TS). Os dados dos experimentos foram aleatoriamente distribuídos em ambos os conjuntos, de maneira que o LS contivesse os extremos de todas as variáveis. O passo seguinte do treinamento da rede foi escolher o melhor número de neurônios para determinadas condições de ajuste e um dado número de apresentações da base de dados. O número de apresentações equivale ao número de vezes que o programa calcula o erro, guardando o conjunto de pesos correspondente ao menor valor deste.

A saída do programa de rede neural fornece quatro conjuntos de dados com valores experimentais e calculados. Estes conjuntos de resposta são indicados como L-L, T-L, L-T e T-T. A primeira letra mostra se os dados experimentais pertencem ao LS (L) ou ao TS (T), e a segunda se os valores calculados foram obtidos com pesos do LS ou do TS (GIROTO, 2002).

Nos primeiros ajustes para 6 neurônios na camada oculta, os dados foram apresentados 20000 vezes à rede neural e a relação entre o número de dados experimentais distribuídos nos conjuntos do LS e do TS foi de 3 (LS/TS=3). A Figura 59 apresenta a raiz quadrada do erro quadrático médio (Root mean square total, RMST) para o LS e o TS em função do número de apresentações.

Não há diferença significativa entre os erros do LS e do TS. Ambos tendem a diminuir em função do número de apresentações e estão próximos. Isso indica que não houve problemas de sobreajuste, situação na qual os erros do LS tendem a diminuir, mas os do TS podem oscilar e apresentar valores mais altos. Comparando os resultados da modelagem para 10000 e 20000 apresentações, não foram obtidas diferenças significativas nos valores de erros quadráticos médios e coeficientes de determinação $(0,99$ para conjunto de resposta $L-L)$. Assim, os demais passos do treinamento da rede foram feitos sempre com 10000 apresentações, que representa um esforço computacional menor. 


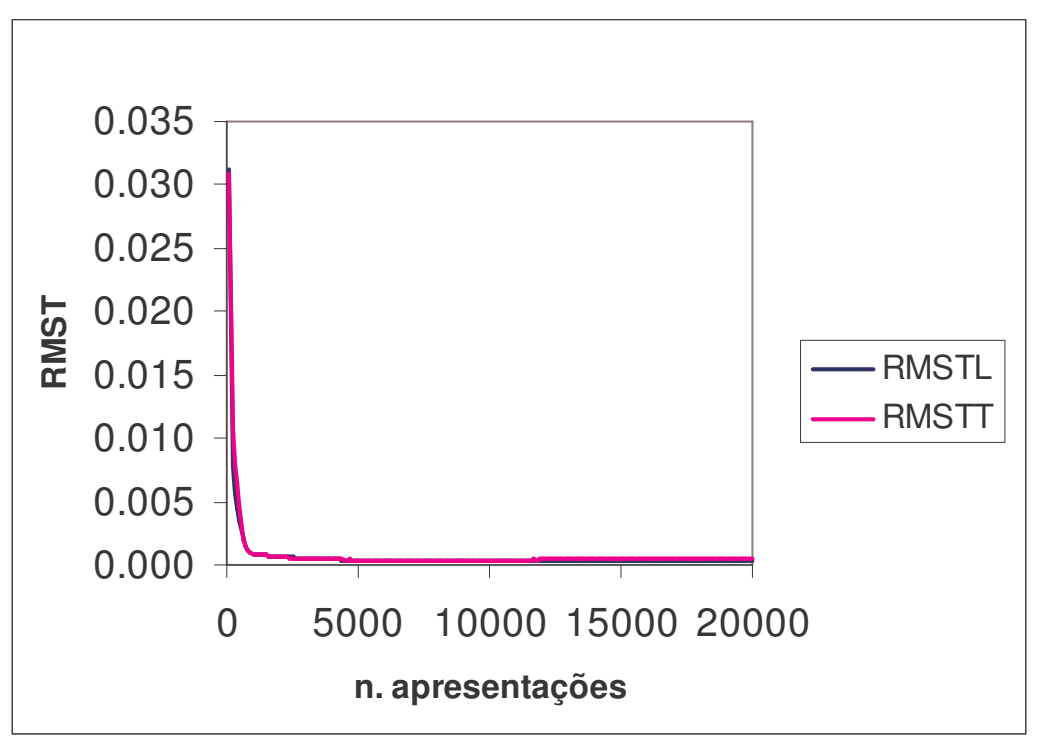

Figura 59 - Raiz quadrada do erro quadrático médio, para o LS (RMSTL) e o TS (RMSTT), em função do número de apresentações ( $\mathrm{NH}=6, \mathrm{n}^{\circ}$ de apresentações $=20000$ e LS/TS=3).

Para os conjuntos L-L e L-T são calculados o resíduo médio por ponto experimental, que é o menor valor de RMST para o LS e para o TS dividido pelo número de experimentos. A partir das análises da variação do resíduo (Figura 60) e dos coeficientes angular e de determinação (Figura 61) selecionou -se o melhor número de neurônios. As redes foram ajustadas com o número de neurônios na camada oculta $(\mathrm{NH})$ variando de 4 a 13 e com número de interações igual a 10000.

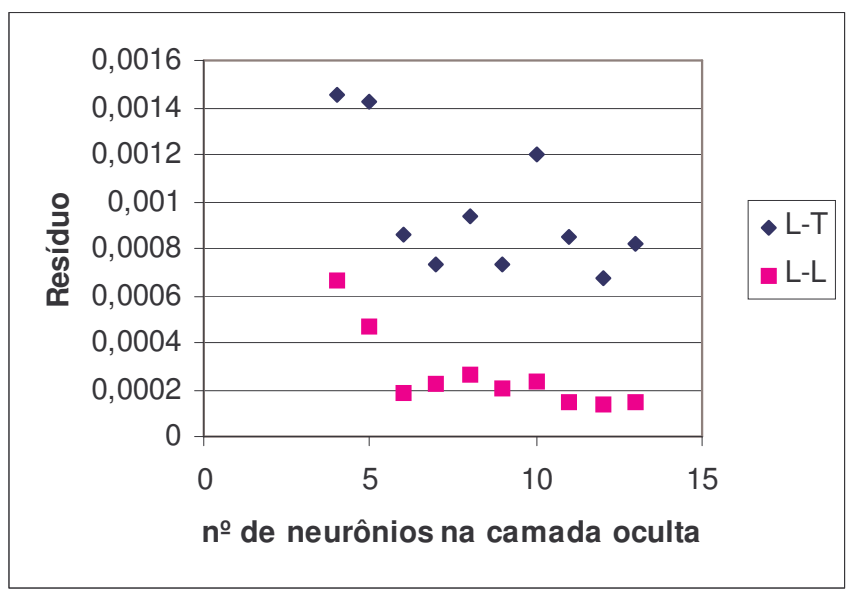

Figura 60 - Resíduo médio por ponto experimental em função do número de neurônios, para o modelo $\mathrm{M}-1$ ( $\mathrm{NH}=4$ a 13, no de apresentações $=10000$ e LS/TS=3).

A eficiência do modelo pode ser avaliada plotando-se os valores calculados em função dos experimentais, pois no caso de um modelo perfeito seria obtida uma reta com inclinação de $45^{\circ}$, e coeficientes angular e de determinação iguais a um.

Um bom ajuste de modelo foi obtido para $\mathrm{NH}=6$, apresentando altos coeficientes de determinação $(0,996$ e 0,977$)$, coeficientes angulares próximos a um e menores resíduos para ambos os conjuntos de dados LS e TS respectivamente 
(Figura 62a). Portanto, optou-se por utilizar 6 neurônios na camada oculta, pois com um número menor de neurônios têm-se menos parâmetros a serem ajustados.

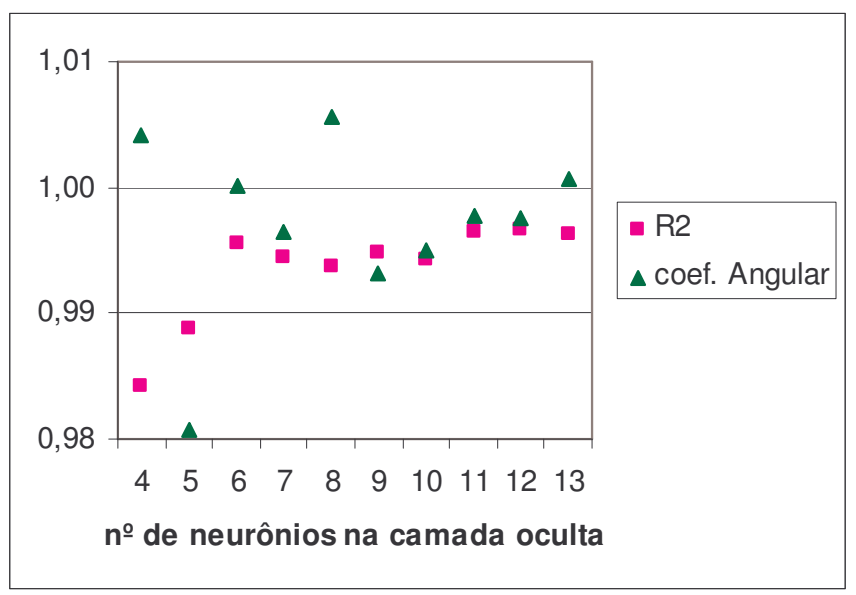

Figura 61 - Coeficientes de determinação (R2) e angular (coef. Angular) em função do número de neurônios, para o modelo M-1 (NH=4 a 13, no de apresentações $=10000$ e LS/TS= 3). Dados do LS.

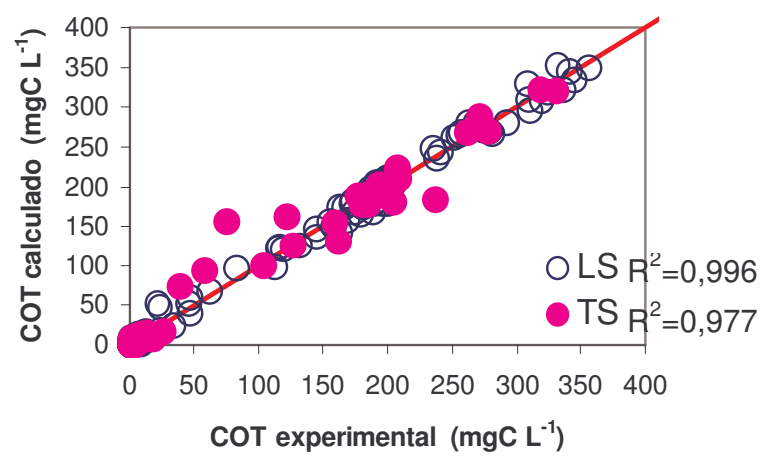

(a)

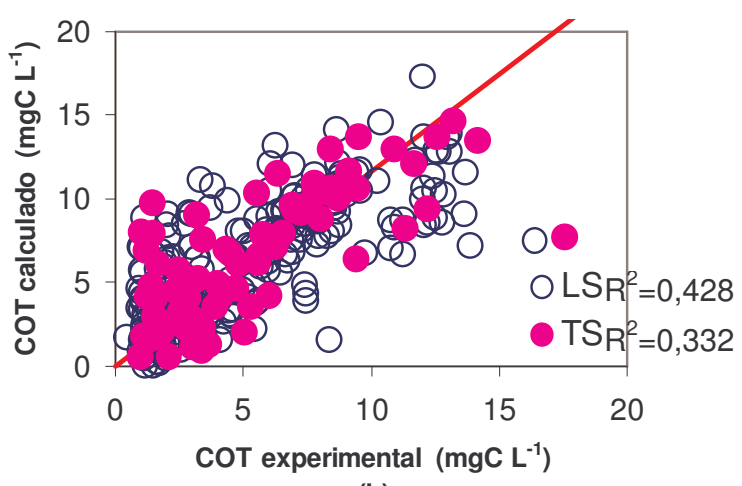

(b)

Figura 62 - Comparação entre COT experimental e calculado para $\mathrm{Nl}=10000$ e $\mathrm{NH}=6$, (a) mostra todos os valores da variável de saída COT e (b) leva em consideração apenas valores de COT menores que $20 \mathrm{mgC} \mathrm{L}^{-1}$.

No entanto, a Figura 62b mostra que existe uma dispersão significativa (baixos coeficientes de determinação, 0,428 e 0,332) para os valores de COT menores de $20 \mathrm{mgC} \mathrm{L}^{-1}$. Ou seja, o modelo ajustado não é capaz de simular o comportamento do sistema para os efluentes que possuem baixa concentração de COT. Este fato pode ser devido a erros experimentais, que podem ter causado grande dispersão nas medidas de COT a baixas concentrações, ou a alterações no comportamento do sistema, implicando, neste último caso, a necessidade de ajuste de modelos diferentes para altas e baixas concentrações de COT. Assim, os dados experimentais foram separados em dois conjuntos: (M-2) efluentes de baixa e (M-3) 
alta concentração inicial de COT. Os resultados dos ajustes desses novos modelos estão apresentados na Figura 63 e na Figura 64.

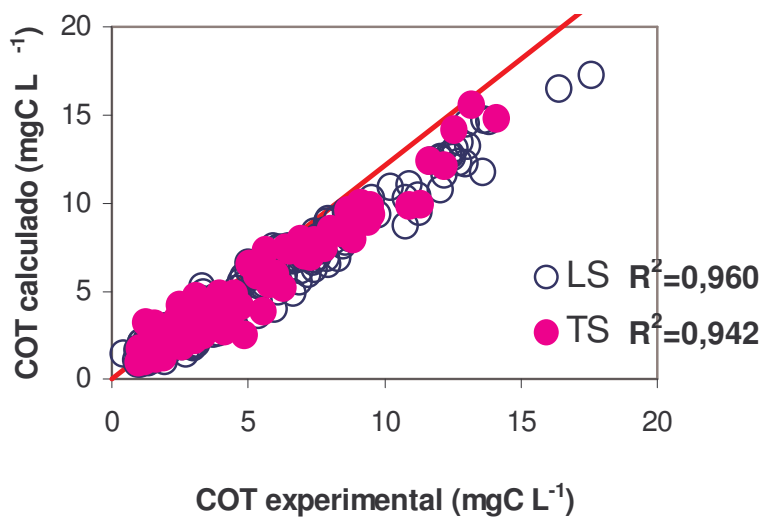

(a)

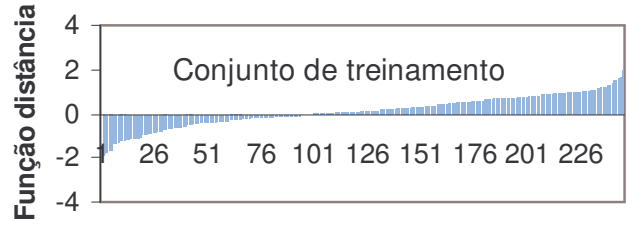

(b)

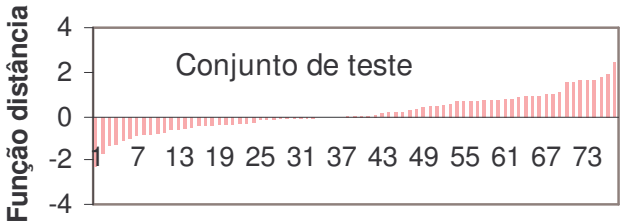

(c)

Figura 63 - Resultados para M-2 (efluentes com baixa concentração de COT), Nl=10000 e NH=5: (a) comparação entre valores de COT experimental e calculado; (b) distribuição da função distância para o conjunto de treinamento (LS) e (c) conjunto de teste (TS). A função distância é a diferença entre COT calculado e experimental.

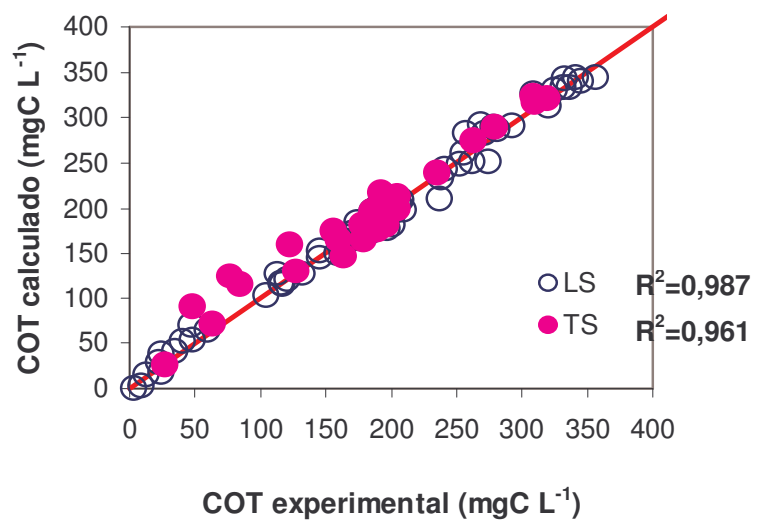

(a)

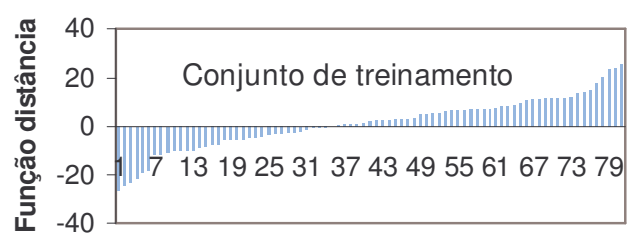

(b)

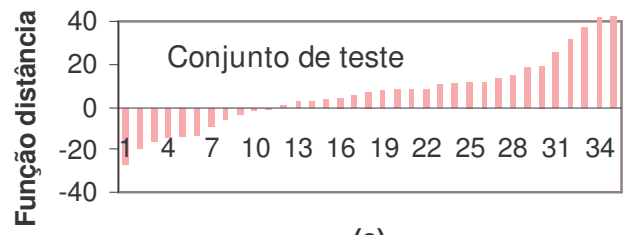

(c)

Figura 64 - Resultados para M-3 (efluente com alta concentração de COT), NI=10000 e NH=7: (a) comparação entre valores de COT experimental e calculado; (b) distribuição da função distância para o conjunto de treinamento (LS) e (c) conjunto de teste (TS). A função distância é a diferença entre COT calculado e experimental.

O ajuste para ambos os modelos foi bom (Figura 63a e Figura 64a). Os gráficos da Figura 63b,c e Figura 64b,c mostram que a função distância está bem distribuída ao longo do domínio experimental. A Tabela 21 apresenta os valores dos principais parâmetros obtidos pelos modelos de rede neural.

Tabela 21 - Parâmetros/Características das redes obtidas

\begin{tabular}{ccccccccc}
\hline & \multicolumn{3}{c}{$\mathbf{n}^{\circ}$ de pares de dados $(\mathbf{x}, \mathbf{y})$} & $\mathbf{N H}^{\mathbf{c}}$ & \multicolumn{2}{c}{$\mathbf{R}^{2}$} & \multicolumn{2}{c}{ coef. Ang. } \\
Modelos & LS $^{\mathbf{a}}$ & TS $^{\mathbf{b}}$ & total & & LS & TS & LS & TS \\
\hline M-1 & 333 & 106 & 439 & 6 & 0,996 & 0,977 & 1,000 & 1,000 \\
M-2 & 246 & 77 & 323 & 5 & 0,960 & 0,942 & 1,007 & 1,026 \\
M-3 & 81 & 35 & 116 & 7 & 0,987 & 0,961 & 1,006 & 1,033 \\
\hline
\end{tabular}

LS: conjunto de treinamento; (b) TS: conjunto de teste; (c) № de neurônios na camada escondida. 
Dentro as faixas experimentais empregadas, os modelos ajustados por redes neurais, com as respectivas matrizes de pesos apresentadas na Tabela 22 e Tabela 23, são capazes de descrever adequadamente a remoção de COT sob diferentes condições e podem ser usados na simulação da taxa de degradação aparente global (Eq. 34), com o modelo ilustrado na Figura 65.

Tabela 22 - Pesos da rede neural (LS) ajustada para modelo $\mathrm{M}-1$ ( $\mathrm{NH}=6 ; \mathrm{NI}=10000)$

\begin{tabular}{|c|c|c|c|c|c|c|c|c|}
\hline \multicolumn{5}{|c|}{$\mathrm{W}_{1}$} & \multicolumn{4}{|c|}{$W_{2}$} \\
\hline Neurônio & $x_{1}$ & $\mathbf{x}_{2}$ & $x_{3}$ & $\mathbf{x}_{4}$ & $x_{5}$ & Bias & Neurônio & $y_{1}$ \\
\hline 1 & $-0,399$ & 0,709 & $-0,785$ & $-0,285$ & 4,345 & 0,976 & 1 & 3,088 \\
\hline 2 & $-1,262$ & 8,776 & 5,867 & 1,540 & $-8,621$ & 0,884 & 2 & $-3,921$ \\
\hline 3 & $-8,892$ & 6,346 & $-6,009$ & $-4,369$ & 6,397 & $-0,181$ & 3 & 2,274 \\
\hline 4 & $-10,561$ & $-6,462$ & $-4,885$ & $-8,374$ & 7,963 & 0,419 & 4 & $-5,184$ \\
\hline 5 & $-15,972$ & 1,280 & $-3,596$ & $-1,076$ & 7,272 & $-0,919$ & 5 & 3,066 \\
\hline 6 & 0,399 & 3,623 & $-5,796$ & $-1,657$ & 3,197 & $-0,436$ & 6 & $-3,234$ \\
\hline & & & & & & & bias & 3,088 \\
\hline
\end{tabular}

$\mathrm{W}_{1}$ : pesos entre a camada de entrada e a camada oculta; $\mathrm{W}_{2}$ : pesos entre a camada oculta e a camada de saída.

Tabela 23 - Pesos da rede neural (LS) ajustada para modelo $\mathrm{M}-2(\mathrm{NH}=5 ; \mathrm{NI}=10000)$

\begin{tabular}{|c|c|c|c|c|c|c|c|c|}
\hline \multirow[b]{2}{*}{ Neurônio } & \multicolumn{3}{|c|}{$\mathrm{W}_{1}$} & \multicolumn{5}{|c|}{$W_{2}$} \\
\hline & $x_{1}$ & $x_{2}$ & $x_{3}$ & $x_{4}$ & $x_{5}$ & Bias & Neurônio & $y_{1}$ \\
\hline 1 & $-10,571$ & 0,327 & $-1,048$ & 0,045 & 1,176 & $-0,629$ & 1 & 5,832 \\
\hline 2 & $-22,642$ & $-2,784$ & $-10,071$ & $-0,469$ & 2,972 & 0,883 & 2 & $-10,755$ \\
\hline 3 & $-0,916$ & $-2,600$ & $-6,700$ & $-0,020$ & 0,053 & 0,268 & 3 & 3,614 \\
\hline 4 & $-33,564$ & $-1,111$ & 1,806 & $-0,535$ & 4,722 & $-0,054$ & 4 & 3,289 \\
\hline \multirow[t]{2}{*}{5} & 7,103 & 1,979 & 19,498 & 1,366 & $-9,801$ & 0,965 & 5 & $-1,531$ \\
\hline & & & & & & & bias & $-0,436$ \\
\hline
\end{tabular}

$\mathrm{W}_{1}$ : pesos entre a camada de entrada e a camada oculta; $\mathrm{W}_{2}$ : pesos entre a camada oculta e a camada de saída.

Tabela 24 - Pesos da rede neural (LS) ajustada para modelo $\mathrm{M}-3(\mathrm{NH}=7 ; \mathrm{NI}=10000)$

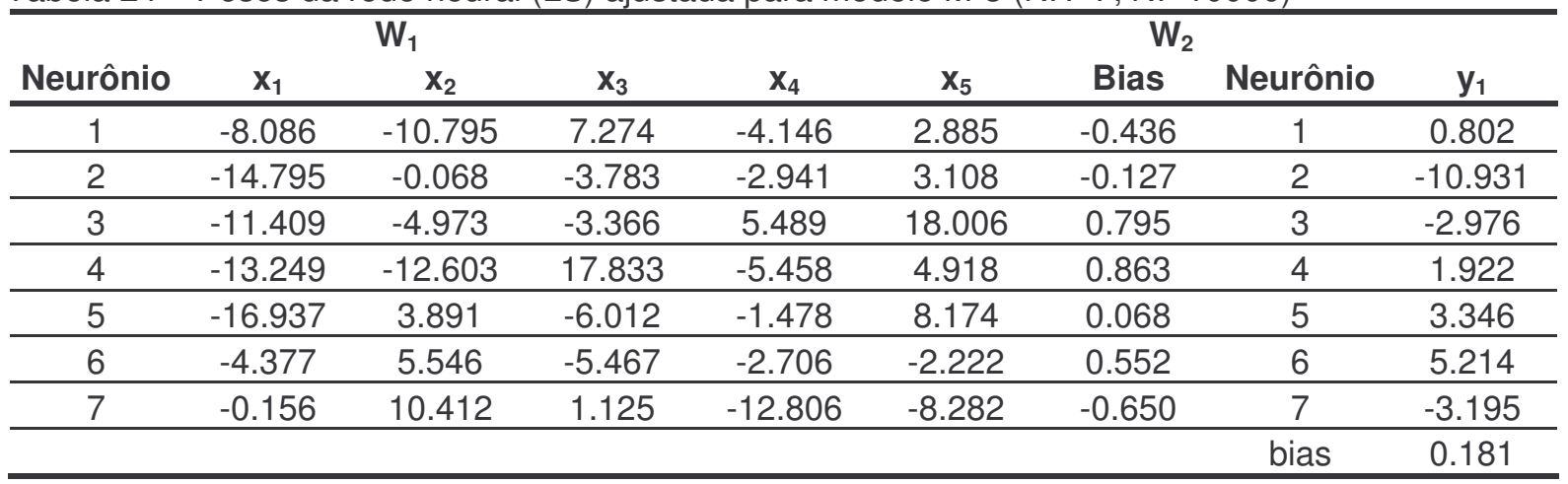

$\mathrm{W}_{1}$ : pesos entre a camada de entrada e a camada oculta; $\mathrm{W}_{2}$ : pesos entre a camada oculta e a camada de saída.

$$
r(t)=f\left(x_{1}, x_{2}, x_{3}, x_{4}, x_{5}\right)
$$




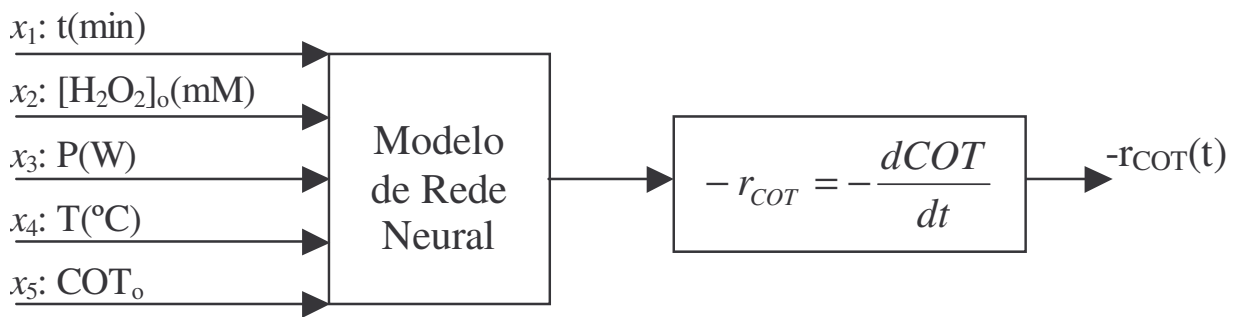

Figura 65 - llustração do modelo usado para o cálculo da taxa de remoção de COT.

A taxa de degradação aparente (taxa de remoção de COT) pode ser obtida diretamente por diferenças finitas dos resultados do modelo de rede neural (TEIXEIRA; GUARDANI; NASCIMENTO, 2004).

\subsubsection{Simulação do Processo UV/ $\mathrm{H}_{2} \mathrm{O}_{2}$}

O processo de degradação em estudo foi simulado através de um programa que utiliza os melhores pesos gerados pelo ajuste por redes neurais. $\mathrm{O}$ algoritmo de cálculo é resumido a seguir:

Entrada de dados:

- tempo total de reação (min) e passo $\Delta$ t suficientemente pequeno para cálculo do COT(t) instantâneo e taxas instantâneas r(t);

- intervalo de tempo para cálculo da taxa média;

- faixa de concentrações iniciais de peróxido de hidrogênio $(\mathrm{mM})$ e 0 intervalo em que esta será dividida, i;

- valores de potências da lâmpada (80, 125, 250 e 400W), j;

- temperatura $\left({ }^{\circ} \mathrm{C}\right): \mathrm{T}$;

- concentração inicial de orgânicos no sistema $\left(\mathrm{mg} \mathrm{L}^{-1}\right)$ : COT

- Matrizes de pesos (LS ou TS) de um dos modelos da rede neural ajustada.

Saída de dados:

- para simular um determinado experimento cujas condições experimentais são definidas por um dado $\mathrm{COT}_{0},\left[\mathrm{H}_{2} \mathrm{O}_{2}\right]_{0}$, Potência e temperatura de reação; o programa retorna a concentração de $\operatorname{COT}(\mathrm{t})$ e a taxa instantânea para um intervalo $\Delta$ t de impressão definido, por exemplo a cada minuto.

- $\operatorname{COT}(\mathrm{t})$ é calculada através do modelo ajustado; 
- a taxa instantânea é dada pela variação de COT no intervalo de tempo e a taxa média é a média aritmética das taxas instantâneas para o intervalo desejado.

- o programa retorna como resultado a taxa média para cada par $\left(\left[\mathrm{H}_{2} \mathrm{O}_{2}\right]_{\mathrm{o}}\right.$, Potência). Com estes dados obtém-se uma superfície de taxas médias para um dado $\mathrm{COT}_{\circ}$ e temperatura em função da potência e da concentração de peróxido de hidrogênio.

No APÊNDICE A é apresentado o código do programa em SCILAB ${ }^{\circledR} 3.0$.

\subsubsection{Discussão dos resultados de simulação}

Experimentos foram simulados com os modelos de rede neurais obtidos e comparados com os resultados experimentais (Figura 66,Figura 67,Figura 68). Primeiramente, os experimentos de alto COT foram simulados através dos pesos obtidos pelo modelo M-1, conforme mostrado na Figura 66.
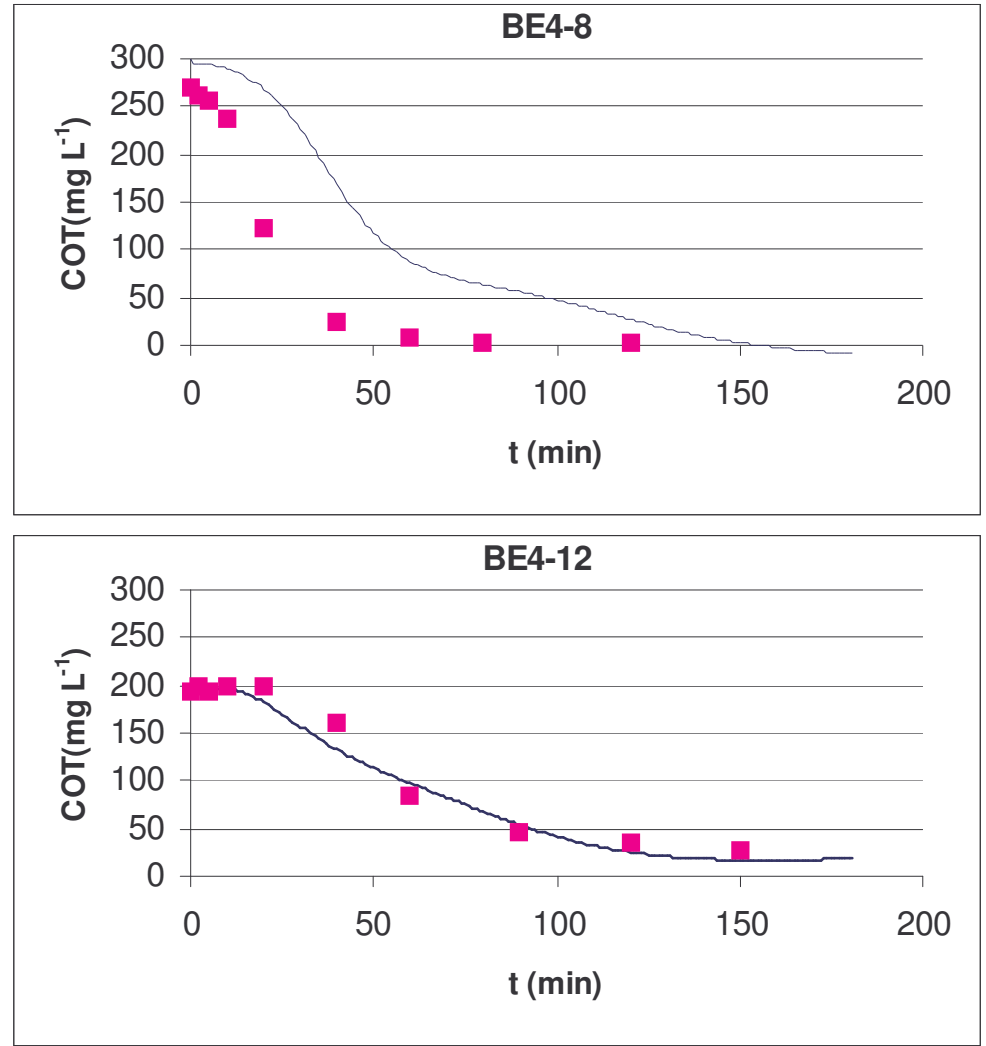

Figura 66 - Comparação dos resultados experimentais ( $₫$ ) e calculados (-) pelo modelo M-1 (alta e baixo teor de matéria orgânica). Experimentos fazem parte da base de dados da RNA para o referido modelo. 
Observa-se que, a simulação do experimento BE4-8 $\left(\mathrm{COT}_{0}=271 \mathrm{mgC} \mathrm{L}^{-1} ; \alpha=\right.$ 18; $P=250 ; T=50^{\circ} \mathrm{C}$ ) não se mostrou satisfatória, apesar deste experimento ter feito parte da base de dados alimentados à rede. Ao mesmo tempo, um bom ajuste foi alcançado através da simulação do experimento BE4-12 $\left(\mathrm{COT}_{0}=195 \mathrm{mgC} \mathrm{L}^{-1}\right.$; $\alpha=$ 9; $\left.\mathrm{P}=125 ; \mathrm{T}=30^{\circ} \mathrm{C}\right)$. Este fato pode estar associado ao número reduzido de pares

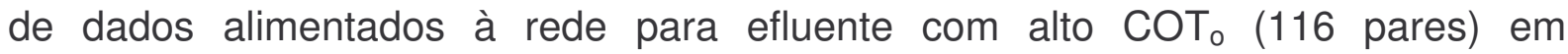
comparação com o número de dados para efluente com baixo COT。 (323 pares). Outra explicação possível é que a qualidade dos dados alimentados à rede pode não ser satisfatória, requerendo uma análise mais cuidadosa para excluir os pontos e/ou experimentos que podem ter prejudicado o ajuste da rede.

Após esta análise, um novo modelo de rede neural artificial foi obtido, modelo M-1a. A Tabela 25 mostra os parâmetros e características da rede e a Tabela 26 os pesos obtidos. Neste modelo o número de dados (419) foi reduzido, em relação ao modelo M-1 (439) para excluir dados aparentemente não coerentes.

Tabela 25 - Parâmetros/Características da rede obtida para modelo M-1a

\begin{tabular}{l|cc}
\hline \multirow{2}{*}{ no de pares de dados $(\mathbf{x}, \mathbf{y})$} & LS $^{\mathbf{a}}$ & $\mathbf{3 1 7}$ \\
\cline { 2 - 3 } & $\mathrm{TS}^{\mathrm{b}}$ & 102 \\
\cline { 2 - 3 } & total & 419 \\
\hline $\mathrm{NH}^{\mathrm{c}}$ & & 6 \\
\hline \multirow{2}{*}{$\mathrm{R}^{2}$} & LS & 0,992 \\
\cline { 2 - 3 } & TS & 0,990 \\
\hline \multirow{2}{*}{ coef. Ang. } & LS & 1,005 \\
\cline { 2 - 3 } & TS & 0,999 \\
\hline
\end{tabular}

LS: conjunto de treinamento; (b) TS: conjunto de teste; (c) № de neurônios na camada escondida.

Tabela 26 - Pesos da rede neural (LS) ajustada para modelo $\mathrm{M}-1$ a $(\mathrm{NH}=6 ; \mathrm{Nl}=10000)$

\begin{tabular}{|c|c|c|c|c|c|c|c|c|}
\hline \multirow[b]{2}{*}{ Neurônio } & \multicolumn{3}{|c|}{$W_{1}$} & \multicolumn{5}{|c|}{$W_{2}$} \\
\hline & $x_{1}$ & $\mathrm{x}_{2}$ & $x_{3}$ & $x_{4}$ & $x_{5}$ & Bias & Neurônio & $y_{1}$ \\
\hline 1 & 3.172 & -4.295 & 0.623 & 0.846 & -5.494 & 0.976 & 1 & 3.356 \\
\hline 2 & -14.315 & -0.442 & -4.339 & -13.086 & 4.690 & 0.884 & 2 & -4.756 \\
\hline 3 & -22.103 & 0.908 & 0.017 & -0.575 & 5.144 & -0.181 & 3 & 2.996 \\
\hline 4 & 0.579 & -1.470 & 0.093 & 0.144 & -7.479 & 0.419 & 4 & -6.269 \\
\hline 5 & -6.471 & 7.234 & -15.205 & -0.372 & 5.196 & -0.919 & 5 & 1.250 \\
\hline \multirow[t]{2}{*}{6} & 6.332 & 7.333 & 2.775 & 3.953 & -11.224 & -0.436 & 6 & -2.069 \\
\hline & & & & & & & bias & -0.282 \\
\hline
\end{tabular}

$\mathrm{W}_{1}$ : pesos entre a camada de entrada e a camada oculta; $\mathrm{W}_{2}$ : pesos entre a camada oculta e a camada de saída.

A concordância entre os pontos do experimento BE4-8 e os valores simulados pelo modelo $\mathrm{M}$-1a mostrou-se melhor nesta nova tentativa, conforme se observa na Figura 67. 

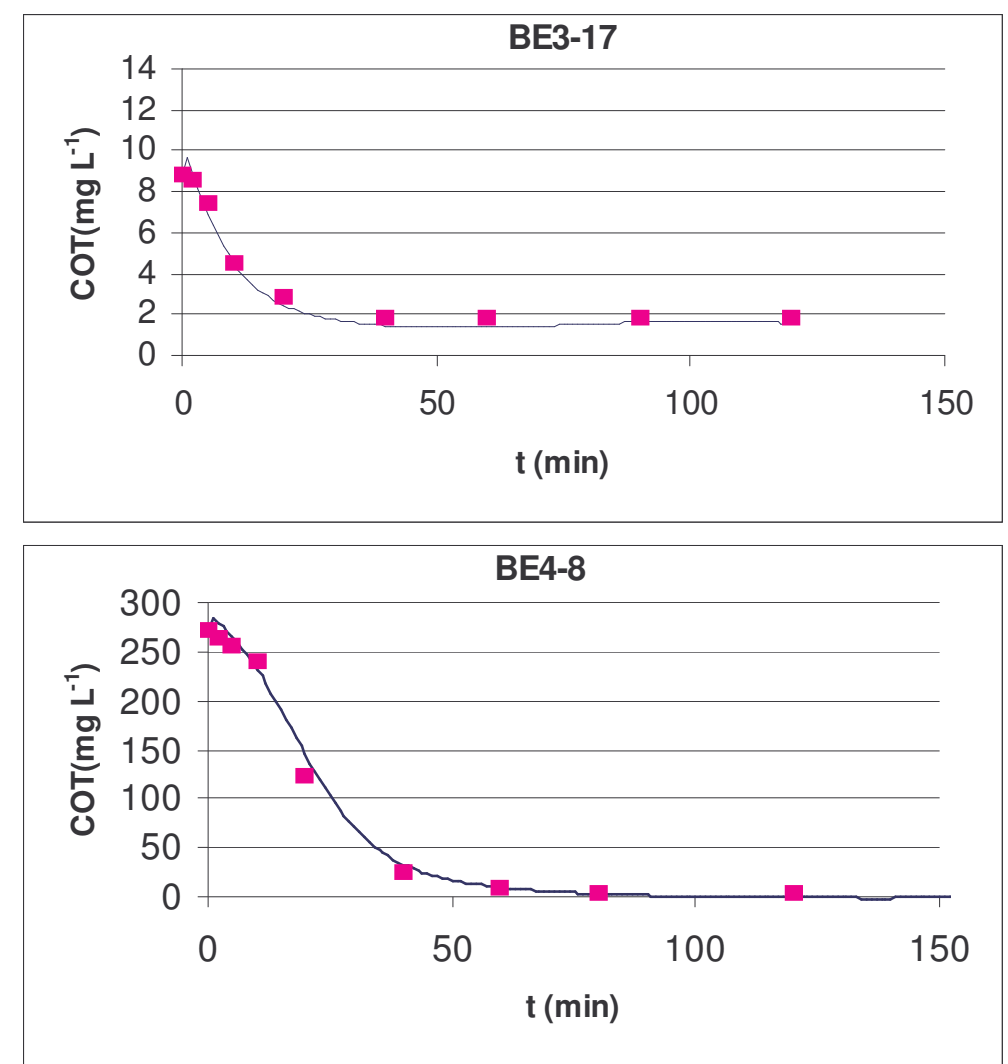

Figura 67 - Comparação dos resultados experimentais ( $₫$ ) e calculados (-) pelo modelo M-1a (alta e baixo teor de matéria orgânica). Experimentos não estão na base de dados RNA para o referido modelo.

A remoção de COT ao longo do tempo também foi simulada para efluentes com baixo $\mathrm{COT}_{0}$. A simulação do experimento BE3-17 $\left(\mathrm{COT}_{0}=9 \mathrm{mgC} \mathrm{L}{ }^{-1} ; \alpha=8 ; P=\right.$ $125 \mathrm{~W} ; \mathrm{T}=30^{\circ} \mathrm{C}$ ) pelo modelo $\mathrm{M}-1 \mathrm{a}$ mostrou-se satisfatória (Figura 67), apesar da grande dispersão dos pontos apresentada (Figura 62) e discutida no item 4.1.4.2 Análise dos dados (4.1.4 Modelagem por Redes Neurais), que mostrava-se parecer prejudicial ao desempenho da rede.

O modelo M-2 também foi usado para simular os experimentos (Figura 68). 

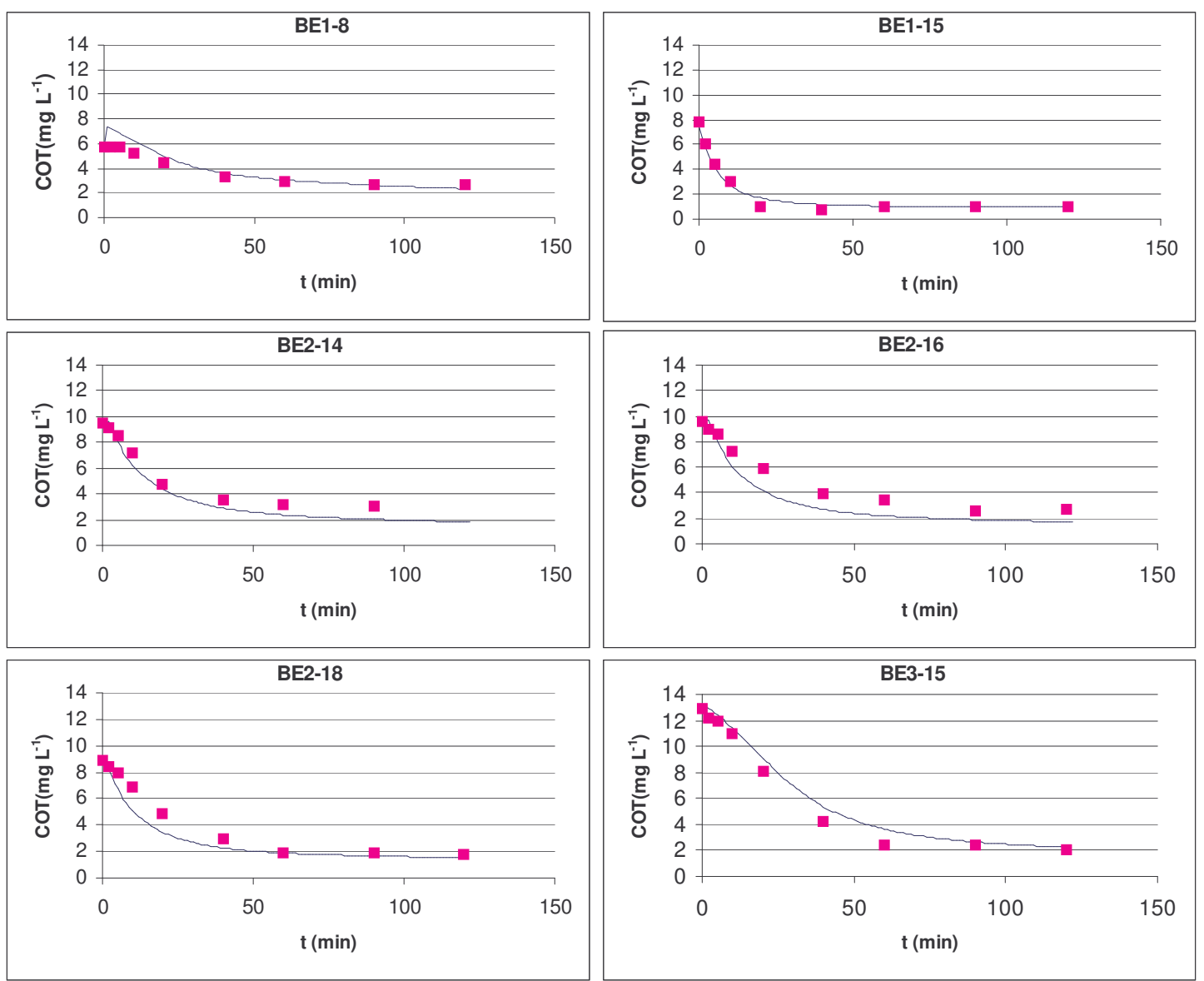

Figura 68 - Comparação dos resultados experimentais (-) e calculados (-) pelo modelo M-2 (baixo teor de matéria orgânica). O experimento BE1-15 é o único que faz parte da base de dados da RNA para o referido modelo; os demais são experimentos independentes.

Em geral, as simulações dos experimentos inclusos no ajuste da rede neural, assim como as dos experimentos independentes, mostraram uma boa concordância entre os resultados experimentais e calculados, principalmente para os experimentos com baixo teor de matéria orgânica. A taxa de degradação aparente obtida a partir dos modelos pode, então, ser usada para o cálculo das conversões em reatores contínuos, caracterizados a partir da distribuição do tempo de residência. Esta abordagem será tratada nos próximos itens.

\subsubsection{Análise de sensibilidade do modelo}

Uma análise de sensibilidade do sistema de reação em relação às variáveis críticas pôde ser efetuada por meio de superfícies de resposta geradas por simulações com o modelo M-2. Estas informações são úteis à otimização do 
processo bem como para o projeto e aumento de escala de reatores fotoquímicos para uso industrial.

Como esperado para processos do tipo estudado, a superfície de resposta mostrada na Figura 69 indica que, no domínio experimental investigado, a potência da lâmpada tem um importante efeito sobre a taxa média de remoção de COT em comparação com a concentração de $\mathrm{H}_{2} \mathrm{O}_{2}$, que possui efeito menor. Esse resultado é ainda mais importante se for considerado que a potência da lâmpada é o principal componente de custo do processo, conforme discutido anteriormente. Pode-se observar que a taxa média de remoção de COT aumenta com o aumento da potência da lâmpada até um nível a partir do qual o processo não é mais afetado, correspondendo a uma potência de cerca de $250 \mathrm{~W}$.

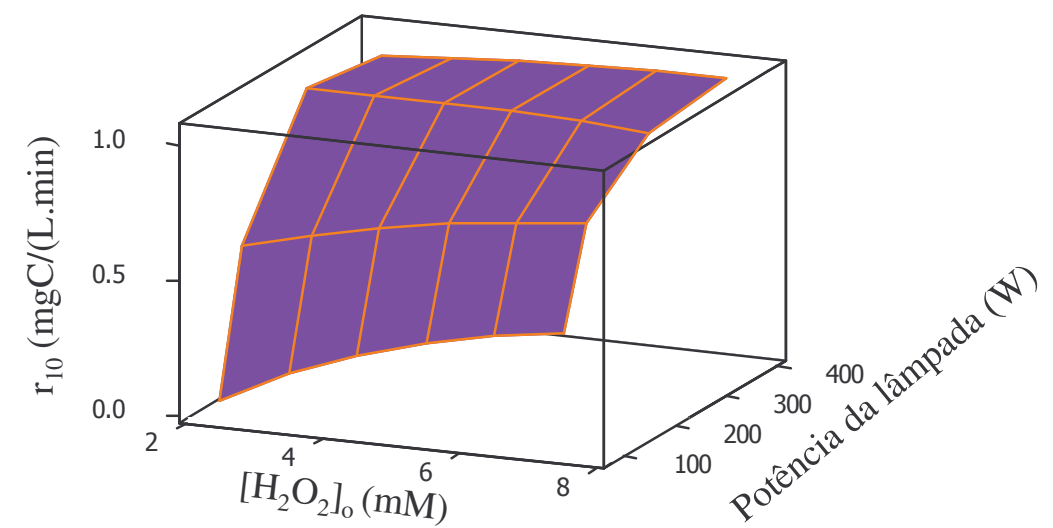

Figura 69 - Simulação da superfície de resposta para taxas médias de remoção de COT (durante os primeiros 10 minutos) como função da concentração de $\mathrm{H}_{2} \mathrm{O}_{2}$ e da potência da fonte de luz. COTo = $15 \mathrm{mgC} \mathrm{L}^{-1}$ e $\mathrm{T}=30^{\circ} \mathrm{C}$.

\subsection{Segunda fase}

\subsubsection{Distribuição de tempos de residência}

A fim de analisar as características de escoamento do reator de múltiplos compartimentos, foram realizados ensaios para medição da distribuição do tempo de residência (DTR). A DTR é uma das mais informativas características sobre a forma 
de contato entre reagentes em um reator químico. Foram realizados cinco ensaios com vazões de alimentação entre 10 e $90 \mathrm{~L} / \mathrm{h}$. Os dados obtidos para as amostras coletadas na saída do reator estão apresentados na Figura 70 e Figura 71 (com tempo normalizado sendo $\theta=\mathrm{t} / \tau$ ). As características da curvas obtidas em cada ensaio estão mostradas na Tabela 27. A função $E(t)$ foi calculada a partir da Eq.(22). A integração relativa a esta equação foi obtida numericamente pela regra do trapézio simples. A concentração de traçador foi inferida pelo valor de absorbância com base na Eq.(19). Para cada curva, o pico máximo foi identificado determinando-se o valor máximo de $\mathrm{E}(\mathrm{t})$ e o respectivo tempo. A Tabela 27 apresenta também o tempo médio de residência $\left(\tau=\frac{V}{Q}\right)$; média da distribuição de tempos de residência $(\bar{t})$, calculada pela Eq.(24); o parâmetro $\bar{t} / \tau$; a variância da distribuição $\sigma^{2}$, calculada pela Eq.(25); o terceiro momento, calculado pela Eq.( 26 ).

Tabela 27 - Condições dos ensaios de DTR e características das curvas obtidas no reator contínuo para vazões entre 10 e $90 \mathrm{~L} / \mathrm{h}$.

\begin{tabular}{|c|c|c|c|c|c|c|c|c|c|}
\hline & \multirow{2}{*}{$\begin{array}{c}\text { Vazão } \\
\text { média } \\
\text { (L/h) }\end{array}$} & \multirow{2}{*}{$\begin{array}{c}\text { desvio } \\
\text { padrão } \\
\text { (L/h) }\end{array}$} & \multicolumn{2}{|c|}{ Pico máximo } & \multirow{2}{*}{$\begin{array}{c}\tau \\
(\min )\end{array}$} & \multirow{2}{*}{$\begin{array}{c}\bar{t} \\
\text { (min) }\end{array}$} & \multirow{2}{*}{$\bar{t} / \tau$} & \multirow{2}{*}{$\begin{array}{c}\sigma^{2} \\
\left(\min ^{2}\right)\end{array}$} & \multirow{2}{*}{$s^{3}$} \\
\hline & & & $E(t)_{\text {máx }}$ & $\begin{array}{c}\text { tempo } \\
\text { (min) }\end{array}$ & & & & & \\
\hline$\square$ Ensaio 1 & 90 & 1,0 & 0,095 & 7 & 9,3 & 9,5 & 1,03 & 31 & 22 \\
\hline$\Delta$ Ensaio 2 & 69 & 0,5 & 0,070 & 8 & 11,9 & 12,1 & 1,01 & 61 & 46 \\
\hline - Ensaio 3 & 50 & 1,0 & 0,052 & 13 & 16,5 & 16,8 & 1,02 & 135 & 82 \\
\hline Ensaio 4 & 31 & 0,8 & 0,034 & 18 & 26,8 & 26,0 & 0,97 & 283 & 185 \\
\hline$\Delta$ Ensaio 5 & 10 & 0,4 & 0,012 & 41 & 82,8 & 74,3 & 0,90 & 3276 & 864 \\
\hline
\end{tabular}

A ocorrência do efeito de cauda nas curvas de todos os experimentos pode ser indicativa de que o traçador tenha sido acumulado parcialmente nas paredes do reator, ou da ocorrência de zonas mortas. Pequenas ondulações na curva E apontam para a existência de alguma recirculação do fluido no interior do reator. No entanto, flutuações observadas dos dados experimentais nas Figura 70 e Figura 71 , podem ser também atribuídas à dificuldade de manter e estimar com precisão as vazões ao longo dos ensaios e à coleta de amostras. 


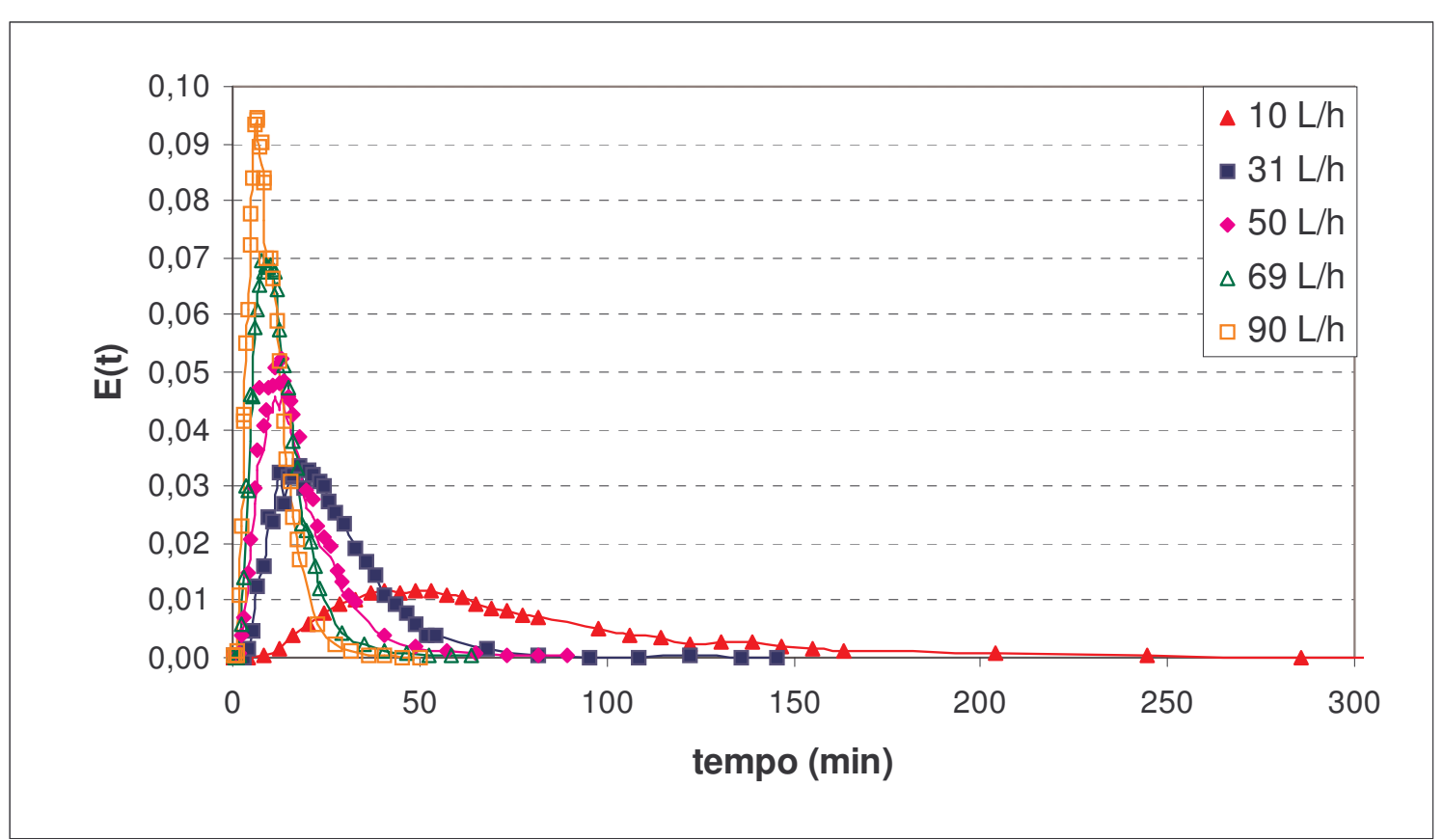

Figura 70 - Curva E (t) $x$ t para reator contínuo em condições variadas de vazão conforme apresentadas na Tabela 27.

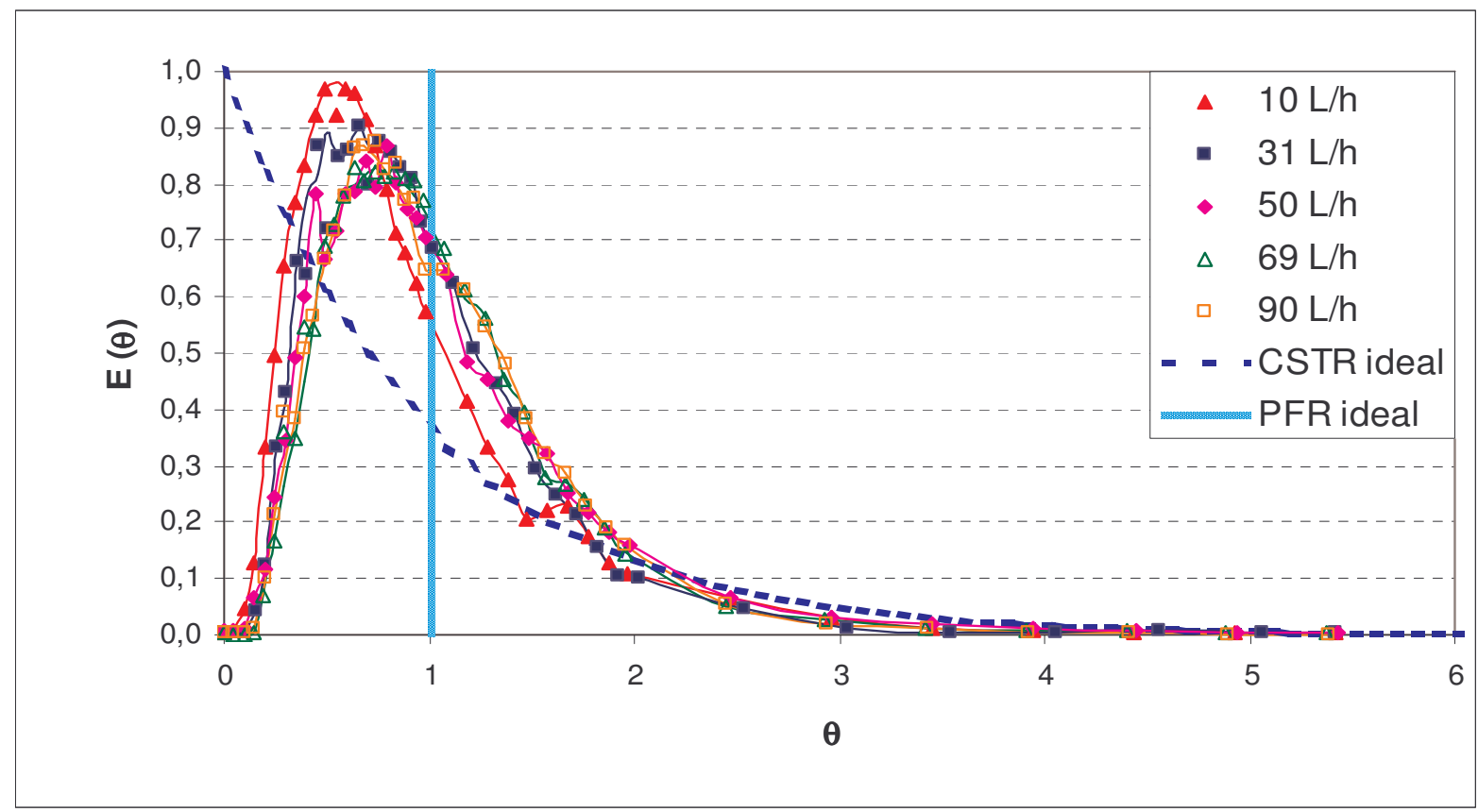

Figura 71 - Curva E $(\Theta)$ para os reatores RFCMS e RFCMI em condições variadas de vazão conforme apresentadas na Tabela 27.Reator de mistura perfeita (---) e reator de fluxo pistonado ideal $(-)$.

A dificuldade de manter a vazão constante ao longo do ensaio tem sua origem na bomba centrífuga utilizada, pois a vazão varia com a altura do nível de água no tanque. Este problema pode ser minimizado mantendo-se a altura do nível constante ou ajustando-se manualmente a vazão ao longo do tempo através da válvula globo. A leitura da vazão torna-se um pouco mais imprecisa para a menor (10L/h) e a maior vazão $(90 \mathrm{~L} / \mathrm{h})$, por serem esses valores próximos dos limites de escala do rotâmetro 
empregado (de 0 a $100 \mathrm{~L} / \mathrm{h}$ ). Por isso, para complementar e verificar a leitura de vazão, medidas de vazão foram efetuadas aleatoriamente durante os ensaios através de testes de proveta. Esse teste consiste em coletar o fluido na saída do reator com o auxílio de proveta de volume adequado para a escala das vazões a serem medidas, cronometrando o tempo gasto para atingir um dado volume. A vazão é o resultado da divisão entre o volume e o tempo medidos.

Desta maneira, foi possível determinar o desvio padrão das vazões para cada ensaio, conforme mostrado na Tabela 28. Os perfis de variação dos valores de vazão para cada ensaio são apresentados no APÊNDICE D.

O efeito da dispersão dos dados de vazão em relação à média foi estimado através do coeficiente de variação, dado pela Eq. ( 35 ):

$c_{v}(\%)=\frac{d_{p}}{x} \cdot 100$

em que: $d_{p}=$ desvio padrão da amostra; $x$ = média aritmética de $n$ amostras.

Os resultados do cálculo do coeficiente de variação para cada um dos perfis de vazão estão apresentados na Tabela 28. As vazões de alimentação apresentaram variações pequenas (coeficiente de variação menor que $5 \%$ em relação ao valor médio). No entanto, quanto menor o valor da média, maior foi o coeficiente de variação da mesma. Esse fato sugere que as medidas nos valores mais baixos são mais imprecisas, conforme comentado anteriormente.

Tabela 28 - Desvio padrão e coeficiente de variação das vazões ensaiadas

\begin{tabular}{cccc}
\hline & vazão $(\mathbf{L} / \mathbf{h})$ & $\mathbf{d}_{\mathrm{p}}(\mathbf{L} / \mathbf{h})$ & $\mathbf{c}_{\mathbf{v}}(\%)$ \\
\hline$\square$ Ensaio 1 & 90 & 1 & 1 \\
\hline$\Delta$ Ensaio 2 & 69 & 0,5 & 1 \\
\hline Ensaio 3 & 50 & 1 & 2 \\
\hline Ensaio 4 & 31 & 0,8 & 3 \\
\hline$\Delta$ Ensaio 5 & 10 & 0,4 & 4 \\
\hline
\end{tabular}

$\mathrm{Na}$ Figura 70, observa-se o forte efeito da vazão de escoamento sobre a curva de DTR. Menores vazões contribuem com maiores valores de dispersão da distribuição de tempos de residência, conforme é verificado na Figura 72 . 


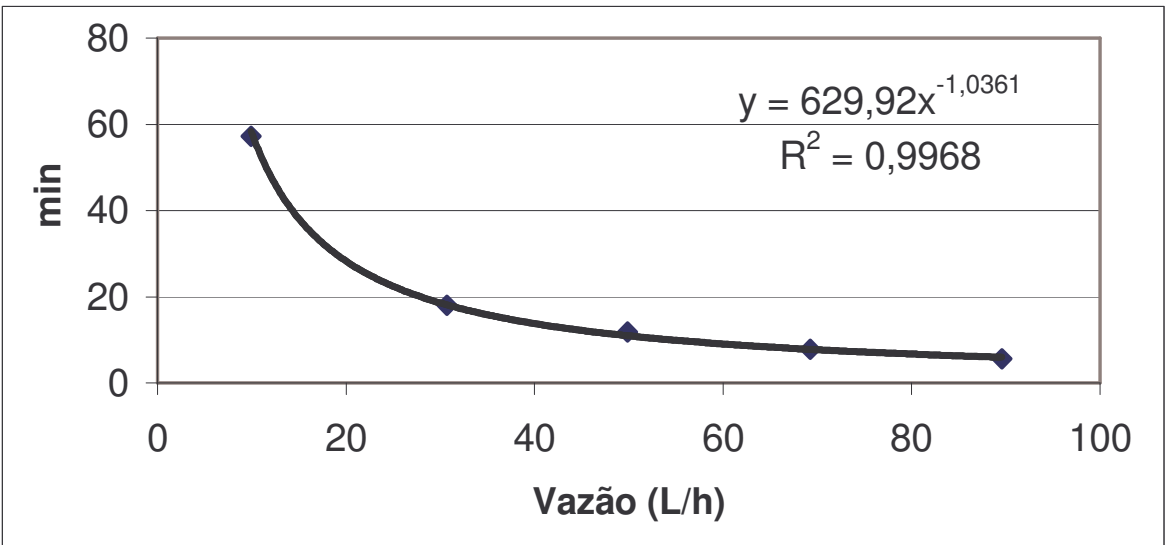

Figura 72 - Desvio padrão das distribuições versus vazão de escoamento.

Para o cálculo do tempo médio de residência $(\tau=V / Q)$, o volume útil do reator foi determinado, pela soma de duas parcelas. A medida da primeira parcela consistiu em preencher completamente com água os compartimentos do reator até o nível máximo, no qual não se verifica transbordamento do fluido na saída do reator, e medir em seguida o volume do conteúdo total, com auxílio de uma proveta. Este volume é denominado volume fixo $\left(\mathrm{V}_{\mathrm{F}}\right)$. No entanto, quando uma corrente é alimentada ao reator, o nível de fluido dentro dele tende a aumentar em função do aumento da vazão. Este volume é denominado de volume devido à altura do vertedor $\left(\mathrm{V}_{\mathrm{v}}\right)$. Sua medida baseou-se em alimentar com água o reator a uma vazão constante e quando o fluxo era interrompido, coletou-se imediatamente o excedente de fluido que saia do reator. O volume útil do reator contínuo (V) é igual à soma das duas parcelas (Eq. 36). $O$ desvio padrão de $V$ é obtido através de propagação de erro (PIMENTEL; RABINOVICH; YAMAMURA, 1985), Eq.(37):

$\mathrm{V}=\mathrm{V}_{\mathrm{F}}+\mathrm{V}_{\mathrm{V}}$

$d_{p}(V)= \pm \sqrt{d_{p}\left(V_{F}\right)^{2}+d_{p}\left(V_{v}\right)^{2}}$

A Tabela 29 apresenta os volumes úteis do reator obtidos para vazões entre 10 e $90 \mathrm{~L} / \mathrm{h}$.

Tabela 29 - Determinação do volume útil do reator em função da vazão.

\begin{tabular}{ccccc}
\hline \multirow{2}{*}{ vazão $(L / h)$} & \multicolumn{2}{c}{$\mathbf{V}_{\mathbf{v}}(\mathrm{L})$} & \multicolumn{2}{c}{$\mathbf{V}(\mathrm{L})$} \\
\cline { 2 - 5 } & média & $\mathbf{d}_{\mathrm{p}}$ & média & $\mathbf{d}_{\mathrm{p}}$ \\
\hline 90 & 0,196 & 0,015 & 13,816 & 0,032 \\
\hline 69 & 0,150 & 0,000 & 13,770 & 0,028 \\
\hline 50 & 0,121 & 0,001 & 13,741 & 0,028 \\
\hline 31 & 0,123 & 0,008 & 13,743 & 0,029 \\
\hline 10 & 0,088 & 0,002 & 13,708 & 0,028 \\
\hline
\end{tabular}

$\mathrm{V}$ : volume útil do reator; $\mathrm{V}_{\mathrm{v}}$ : Volume devido à altura do vertedor; O volume fixo $\mathrm{V}_{\mathrm{F}}$ é igual a $13,62 \pm$ $0,028 \mathrm{~L}$ 
Portanto, o desvio padrão do tempo médio de residência $(\tau=V / Q)$ pode ser determinado indiretamente por propagação de erros:

$d_{p}(\tau)= \pm \tau \sqrt{\frac{d_{p}(V)^{2}}{V^{2}}+\frac{d_{p}(Q)^{2}}{Q^{2}}}$

Tabela 30 - Determinação do desvio padrão de $\tau-d_{p}(\tau)$

\begin{tabular}{ccccccc}
\hline & $\mathbf{V}(\mathbf{L})$ & $\mathbf{d}_{\mathbf{p}}(\mathbf{V})(\mathbf{L})$ & $\mathbf{Q}(\mathbf{l} / \mathbf{h})$ & $\mathbf{d}_{\mathrm{p}}(\mathbf{Q})(\mathbf{l} / \mathbf{h})$ & $\boldsymbol{\tau}(\mathbf{m i n})$ & $\mathbf{d}_{\mathrm{p}}(\boldsymbol{\tau})(\mathbf{m i n})$ \\
\hline Ensaio 1 & 13,816 & 0,032 & 90 & 1,0 & 9,3 & 0,1 \\
\hline$\Delta$ Ensaio 2 & 13,770 & 0,028 & 69 & 0,5 & 11,9 & 0,09 \\
\hline Ensaio 3 & 13,741 & 0,028 & 50 & 1,0 & 16,5 & 0,32 \\
\hline Ensaio 4 & 13,743 & 0,029 & 31 & 0,8 & 26,8 & 0,73 \\
\hline$\Delta$ Ensaio 5 & 13,708 & 0,028 & 10 & 0,5 & 82,8 & 3,8 \\
\hline
\end{tabular}

Segundo Himmelblau e Bischoff (1967), na prática, os dados experimentais para tempos $\theta$ maiores que 2 a 3 tempos médios de residência raramente possuem precisão adequada para serem usados nos cálculos, devido ao lento decaimento e imprecisão nas determinações de concentrações para baixos valores. Portanto as integrais devem ser truncadas em $\theta=2$ ou 3. Sassaki (2005) sugere que a integral relativa à Eq.(24) seja calculada em parte numericamente e em parte analiticamente, ajustando o trecho de lento decaimento por uma função exponencial. Neste trabalho, adotou-se o ajuste de uma função exponencial para o trecho da curva no qual $\theta>2$, conforme apresentado Eq. (39).

$$
E(t)=\kappa \cdot e^{(\omega \cdot t)} \quad \text { para } \quad \theta>2 \Rightarrow t>2 \cdot \tau
$$

A média da distribuição de tempos de residência $(\bar{t})$ foi calculada integrandose numericamente 0 trecho de $\theta=0$ a $\theta=2$ e analiticamente a função exponencial ajustada para $\theta>2$.

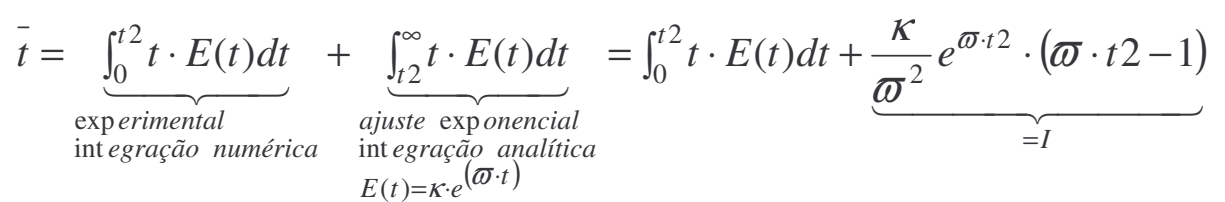

Para estimar o desvio padrão da média da distribuição de tempos de residência $(\bar{t})$, o ensaio 4 foi repetido (Figura 73 ). 


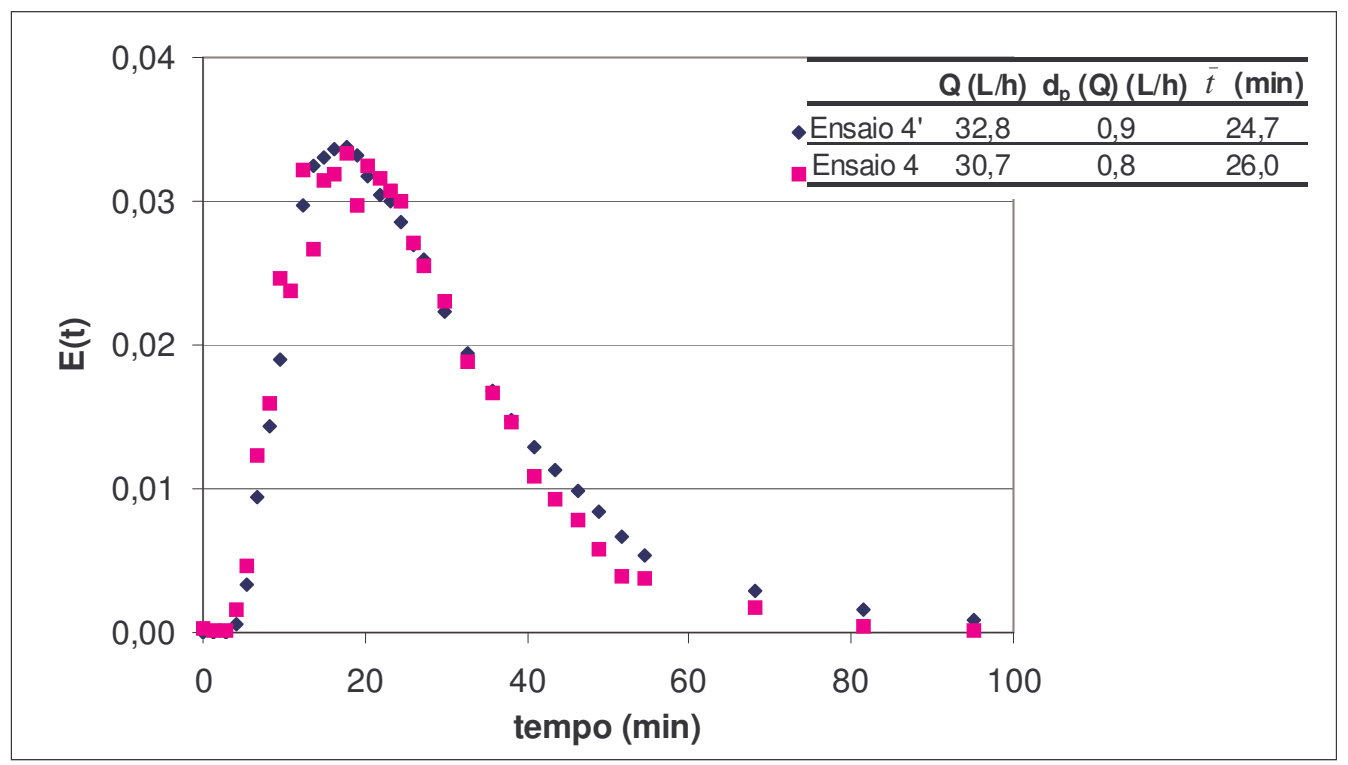

Figura 73 - Curva $E(t)$ versus t do ensaio 4 e repetição 4'.

$\mathrm{Na}$ Figura 73, observa-se que os dados dos ensaios 4 e 4' estão condizentes, apresentando uma boa reprodutibilidade. $O$ erro foi de $4,17 \cdot 10^{-6}$. $O$ desvio padrão estimado para a média da distribuição de tempos de residência é de 0,92 min.

A existência de zona morta pode ser identificada através da curva de DTR, que possuirá uma cauda longa indicando que o fluido está estagnado na zona morta. O verdadeiro tempo médio de residência será igual a $\tau=V / Q$.

A fim de caracterizar o escoamento no reator com bases em fundamentos teóricos, para cada um dos ensaios procurou-se ajustar aos dados experimentais modelos de distribuição de tempos de residência com significado físico, ou seja, estes modelos contêm elementos necessários para descrever apropriadamente o processo físico. O reator contínuo estudado possui quatro compartimentos de volumes aproximadamente iguais, então é coerente propor um modelo de quatro reatores de mistura perfeita em série (modelo $A$ ) ou um modelo de quatro reatores de mistura perfeita em série com zonas mortas (modelo B). $O$ equacionamento dos modelos propostos é apresentado no APÊNDICE B.

No APÊNDICE D, encontram-se os resultados gerais de distribuição de tempos de residência no reator contínuo.

A existência de regiões de zona morta pode ser determinada através do cálculo da média de distribuição de tempos de residência $(\bar{t})$, truncado em $\theta=2,5$ (Himmelblau e Bischoff, 1967). Se a região de zona morta está presente no reator: $\bar{t}<\tau$ ou $\bar{\theta}<1$. Então o volume de zona morta é obtido pela equação a seguir: 


$$
\bar{t}=\frac{V_{a T}}{Q}=\frac{V-V_{d T}}{Q}=\tau \cdot \bar{\theta} \Rightarrow V_{a T}=Q \cdot \bar{t}
$$

A Tabela 31 abaixo mostra o cálculo estimativo de $\mathrm{V}_{\mathrm{dT}}$. Os gráficos a seguir ilustram os ajustes dos modelos para cada condição experimental.

Tabela 31 - Volumes estimados para a zona morta

\begin{tabular}{|c|c|c|c|c|c|}
\hline & $V(L){ }^{*}$ & $Q(1 / h)$ & $\tau(\min )$ & $t(\min )$ & $\mathrm{V}_{\mathrm{dT}}(\min )$ \\
\hline Ensaio 1 & 13,82 & 90 & 9,3 & 9,8 & $-0,8 \pm 1,3$ \\
\hline$\Delta$ Ensaio 2 & 13,77 & 69 & 11,9 & 11,8 & $0,2 \pm 1,0$ \\
\hline - Ensaio 3 & 13,74 & 50 & 16,5 & 17,5 & $-0,8 \pm 0,8$ \\
\hline - Ensaio 4 & 13,74 & 31 & 26,8 & 25,5 & $0,7 \pm 0,6$ \\
\hline$\Delta$ Ensaio 5 & 13,71 & 10 & 82,8 & 70,2 & $2,1 \pm 0,6$ \\
\hline
\end{tabular}

${ }^{*}$ Volume do reator preenchido pelo líquido depende da vazão

Através do cálculo de volume de zona morta total observa-se que, para os ensaios de 1 a 4 , os volumes obtidos foram insignificantes. Obtiveram-se alguns valores negativos, o que é fisicamente incorreto, mas levando em consideração os erros inerentes aos ensaios, tais como: oscilações da vazão, dispersão no ponto de injeção de traçador, coletas de amostras, medição do volume útil do reator, pode-se considerar que a região de zona morta para estes ensaios seja nula. Para o ensaio 5 , o volume estimado foi um pouco maior, indicando uma possível existência de zona morta. Observa-se através do gráfico do ensaio 5 que o modelo que melhor se ajustou foi o $\mathrm{A}$, considerando zona morta. No entanto, a pequena ondulação observada na cauda dos dados experimentais indica que este modelo (A) pode ser melhorado se for considerado no modelo um elemento que represente um reciclo ou um atraso no aparecimento de uma porção do fluido. Esta provável recirculação pode ser atribuída à baixa vazão ensaiada. 

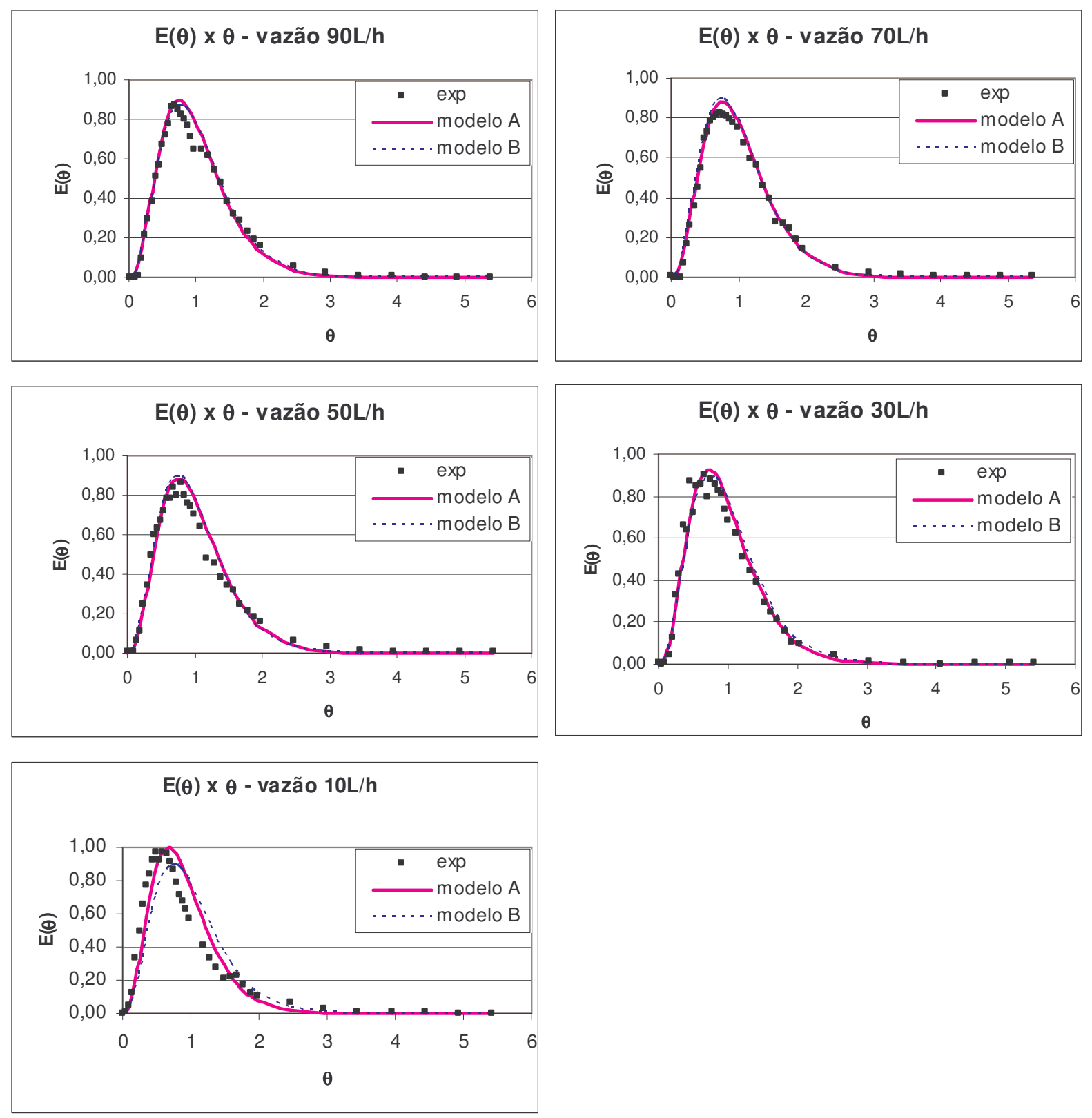

Figura 74 - Ajustes de modelos aos dados experimentais

Os resultados de DTR indicam que o projeto do reator é satisfatório, visto que este pode ser representado por modelos ideais. Com isso, na etapa a seguir podese testar o reator para a finalidade a que ele se destina: o processo fotoquímico de tratamento de efluente. 


\subsubsection{Ensaios fotoquímicos nos Reatores Contínuos}

Nos experimentos com reator fotoquímico contínuo utilizou-se o efluente E1, de uma indústria petroquímica coletado após filtro do tipo semi-bag de 200 mesh

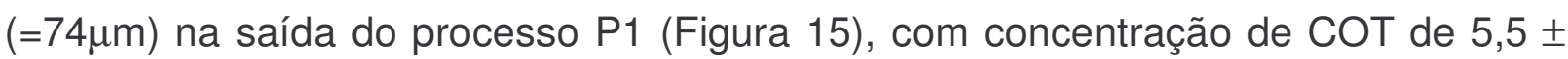
$0,9 \mathrm{mgC} \mathrm{\textrm {L } ^ { - 1 }}$. O efluente e a solução de $\mathrm{H}_{2} \mathrm{O}_{2}$ foram alimentados no primeiro compartimento do reator contínuo, conforme representado na Figura 75. A dose de peróxido em relação ao COT alimentado ao reator foi de $\alpha=14,0 \pm 2,3 \mathrm{mgH}_{2} \mathrm{O}_{2} / \mathrm{mg}$ C. A degradação dos compostos contidos no efluente foi investigada em função da potência das lâmpadas e vazão alimentada ao sistema, conforme a Tabela 32. A temperatura inicial foi a ambiente. $\mathrm{O}$ valor de $\mathrm{pH}$ inicial correspondeu a $\mathrm{pH}$ natural do efluente. Durante os ensaios contínuos, a temperatura e o $\mathrm{pH}$ não foram controlados, apenas monitorados.

Tabela 32 - Condições dos experimentos contínuos

\begin{tabular}{|c|c|}
\hline Variáveis & Faixa de valores \\
\hline Potência elétrica total no sistema & $4 \times(125 W), 4 \times(250 W)$ e $4 \times(400 W)$ \\
\hline Vazão de efluente na entrada & $10,30,50,70$ e 90 L.h $^{-1}$ \\
\hline \multicolumn{2}{|c|}{$\begin{array}{l}\text { Valor correspondente à soma da potência de quatro lâmpadas a vapor de mercúrio de média } \\
\text { pressão (Philips, } 125,250 \text { e } 400 \mathrm{~W} \text {, modelo } \mathrm{HPL}-\mathrm{N}) \text { que são inseridas em cada um dos quatro } \\
\text { compartimentos do reator }\left(\mathrm{P}_{\mathrm{T}}=\mathrm{P}_{1}+\mathrm{P}_{2}+\mathrm{P}_{3}+\mathrm{P}_{4}\right) \text {. }\end{array}$} \\
\hline
\end{tabular}

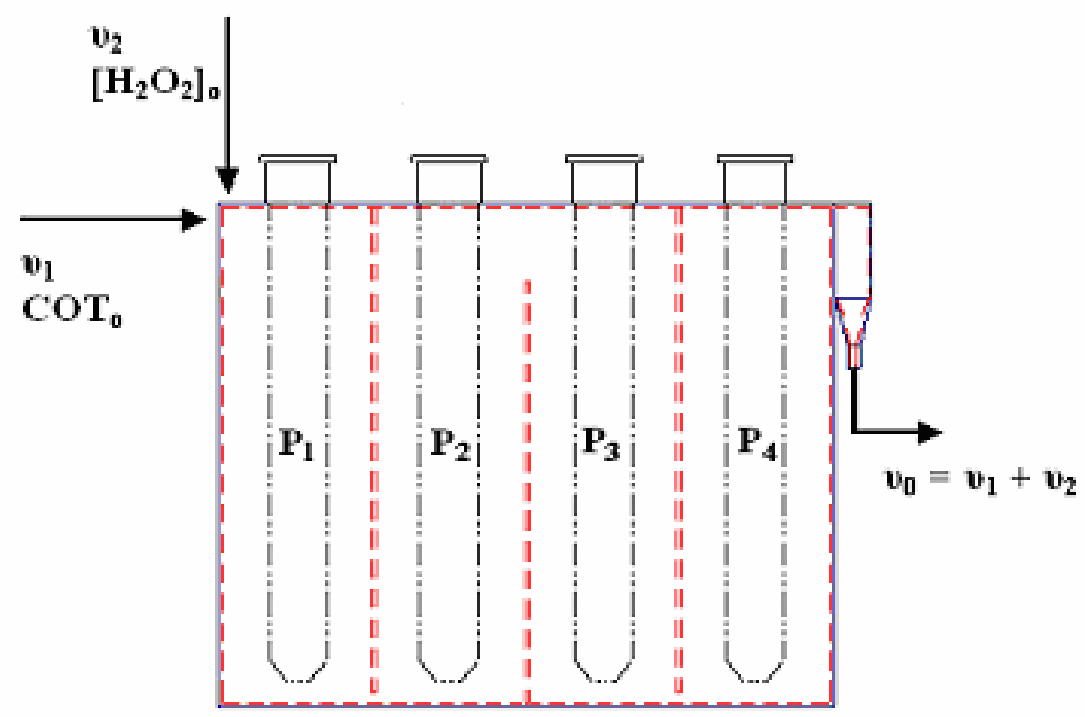

Figura 75 - Esquema dos fluxos de entradas e saídas no reator contínuo tipo RCFMI.

Os efeitos da potência da lâmpada e da vazão foram avaliados a partir de um planejamento de experimentos de acordo com uma metodologia conhecida como matriz Doehlert (SAUTOUR et al., 2001). Essa metodologia, baseada em métodos 
multivariáveis, provê o levantamento de um modelo estatístico a partir de um mínimo número de experimentos, adequadamente distribuídos no domínio experimental.

Os sete experimentos, realizados para o caso de uma matriz Doehlert de 2 variáveis, são uniformemente distribuídos e podem ser representados em um plano, na forma codificada, através das extremidades e do centro de um hexágono, com as coordenadas apresentadas na Tabela 33 e Figura 77. A Tabela 34 apresenta as condições experimentais dos ensaios realizados e dos 2 ensaios adicionais do ponto central utilizados para o cálculo da estimativa do erro experimental. Os níveis mínimos e máximos de cada fator (vazão e potência) foram escolhidos de acordo com experimentos prévios realizados no sistema batelada. A Figura 76 apresenta os valores de COT em função do tempo para os experimentos do planejamento Doehlert. Nesta figura o ponto central foi representado apenas pelo experimento 1. Uma análise englobando os demais pontos centrais do planejamento é mostrada posteriormente. Os resultados gerais dos ensaios fotoquímicos contínuos estão apresentados no APÊNDICE E.

Tabela 33 - Plano de experimentos Doehlert

\begin{tabular}{ccccccc}
\hline $\exp$ & vazão $(\mathbf{L} / \mathbf{h})$ & $\boldsymbol{\tau}(\boldsymbol{m i n})$ & potência $(\mathbf{W})^{\mathbf{A}}$ & $\mathbf{x}_{\mathbf{1}}$ & $\mathbf{x}_{\mathbf{2}}$ & Eficiência de remoção de COT (\%) \\
\hline 1 & 50 & 16,5 & 1000 & 0 & 0 & 53 \\
\hline 2 & 30 & 26,8 & 1600 & $-0,5$ & 0,866 & 85 \\
\hline 3 & 10 & 82,8 & 1000 & -1 & 0 & 77 \\
\hline 4 & 30 & 26,8 & 500 & $-0,5$ & $-0,866$ & 17 \\
\hline 5 & 70 & 11,9 & 500 & 0,5 & $-0,866$ & 29 \\
\hline 6 & 90 & 9,3 & 1000 & 1 & 0 & 53 \\
\hline 7 & 70 & 11,9 & 1600 & 0,5 & 0,866 & 63 \\
\hline 8 & 50 & 16,5 & 1000 & 0 & 0 & 55 \\
\hline 9 & 50 & 16,5 & 1000 & 0 & 0 & 0
\end{tabular}

${ }^{A}$ Os valores de potência foram arredondados de acordo com as potências de lâmpadas disponíveis. $\mathrm{x}_{1}$ : Variável codificada de vazão (adimensional)

$\mathrm{x}_{2}$ : Variável codificada de potência (adimensional)

Tabela 34 - Condições experimentais dos ensaios realizados no reator continuo

\begin{tabular}{cccccccccc}
\hline $\exp$ & $\begin{array}{c}\text { COTo } \\
\left(\mathbf{m g C ~ L}^{-1}\right)\end{array}$ & $\begin{array}{c}\mathbf{v}_{\mathbf{1}} \\
\left(\mathbf{L ~ h}^{-1}\right)\end{array}$ & $\begin{array}{c}\mathbf{v}_{\mathbf{0}} \\
\left(\mathbf{L ~ h ~}^{-1}\right)\end{array}$ & $\begin{array}{c}\mathbf{F}_{\mathbf{H 2 O} 2} \\
\left(\mathbf{g ~ h}^{-1}\right)\end{array}$ & $\mathbf{\alpha}$ & $\mathbf{P}_{\mathbf{1}}(\mathbf{W})$ & $\mathbf{P}_{\mathbf{2}}(\mathbf{W})$ & $\mathbf{P}_{\mathbf{3}}(\mathbf{W})$ & $\mathbf{P}_{\mathbf{4}}(\mathbf{W})$ \\
\hline 1 & 5,6 & 50 & 51 & 4,0 & 14 & 250 & 250 & 250 & 250 \\
\hline 2 & 6,2 & 30 & 31 & 2,4 & 13 & 400 & 400 & 400 & 400 \\
\hline 3 & 6,8 & 10 & 10 & 0,7 & 11 & 250 & 250 & 250 & 250 \\
\hline 4 & 6,2 & 30 & 31 & 2,4 & 13 & 125 & 125 & 125 & 125 \\
\hline 5 & 5,6 & 70 & 72 & 5,1 & 13 & 125 & 125 & 125 & 125 \\
\hline 6 & 5,8 & 90 & 92 & 6,6 & 13 & 250 & 250 & 250 & 250 \\
\hline 7 & 5,0 & 70 & 72 & 5,1 & 17 & 400 & 400 & 400 & 400 \\
\hline 8 & 4,0 & 50 & 51 & 3,6 & 18 & 250 & 250 & 250 & 250 \\
\hline 9 & 4,7 & 50 & 51 & 3,4 & 14 & 250 & 250 & 250 & 250 \\
\hline
\end{tabular}




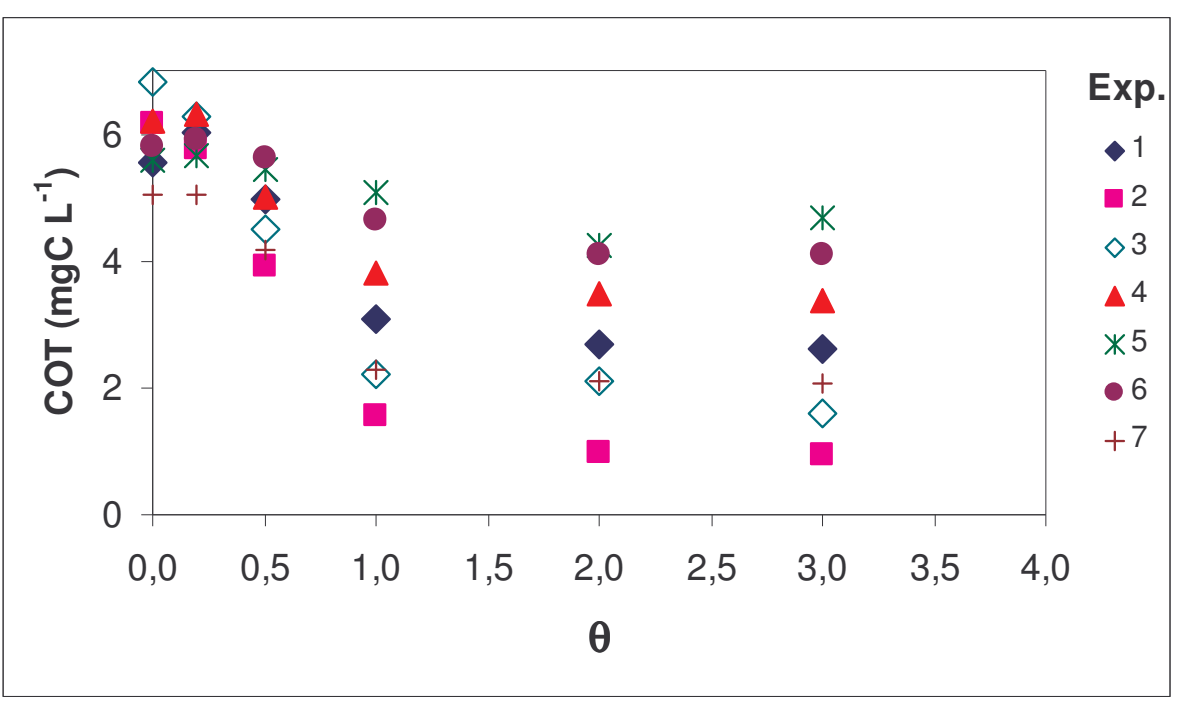

Figura 76 - COT em função de $\theta$ para os ensaios contínuos, do plano experimental.

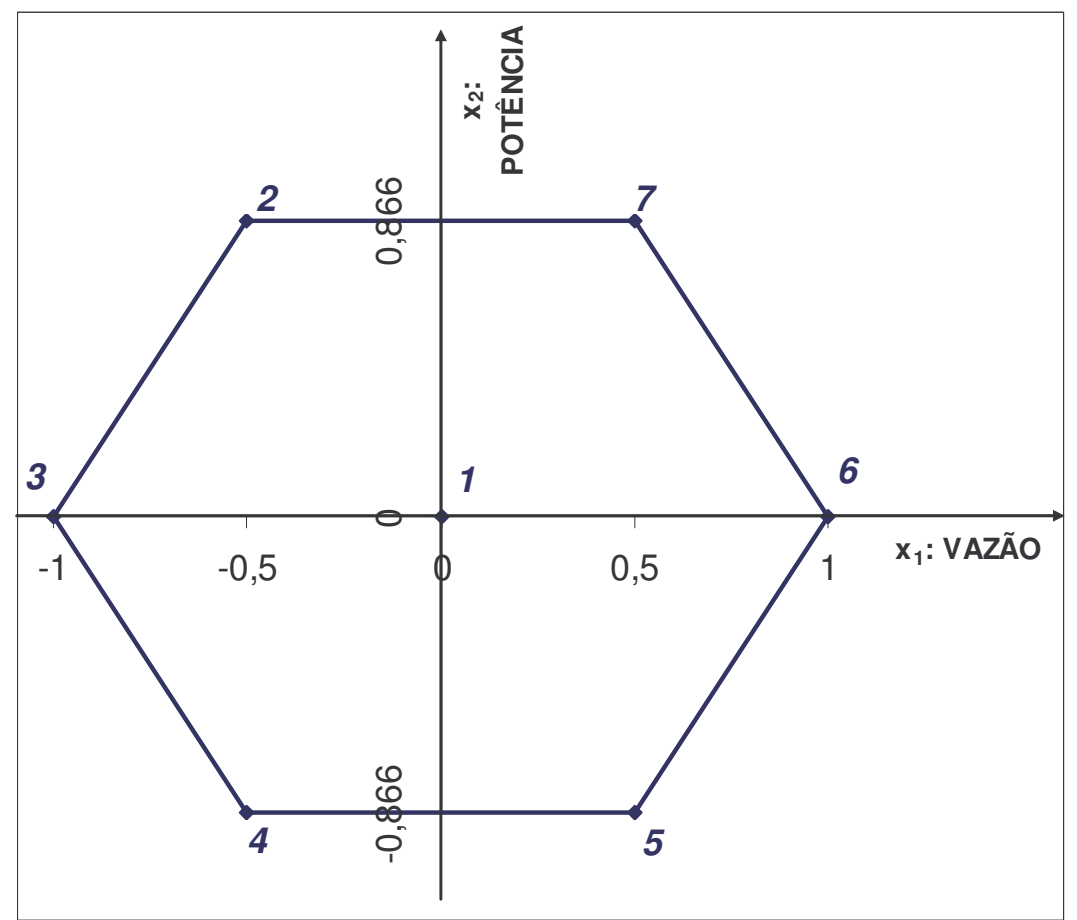

Figura 77 - Representação do Plano de experimentos Doehlert.

A análise dos resultados é iniciada admitindo que a superfície de resposta na região investigada seja uma função quadrática, cuja expressão geral, para duas variáveis, é:

$$
\operatorname{\Delta COT}(\%)=b_{o}+b_{1} x_{1}+b_{2} x_{2}+b_{11} x_{1}^{2}+b_{22} x_{2}^{2}+b_{12} x_{1} x_{2}
$$

A análise de regressão pelo método de ajuste por mínimos quadrados fornece a estimativa dos coeficientes do modelo a partir dos dados apresentados na Tabela 33: 


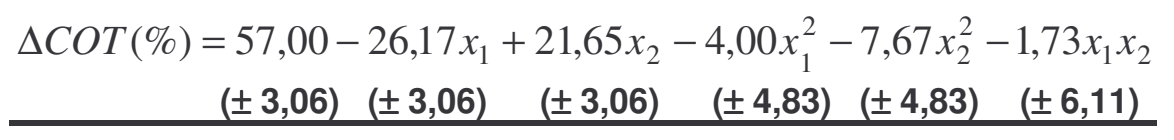

Os valores entre parênteses são os erros padrões dos coeficientes do modelo. Os coeficientes dos termos quadráticos não são estatisticamente significativos, pois os valores de erros padrões são grandes em relação aos coeficientes.

O erro do modelo estimado a partir do ponto central foi de $\pm 5,3 \%$.

O coeficiente de determinação, $r^{2}$, é de 0,98 .

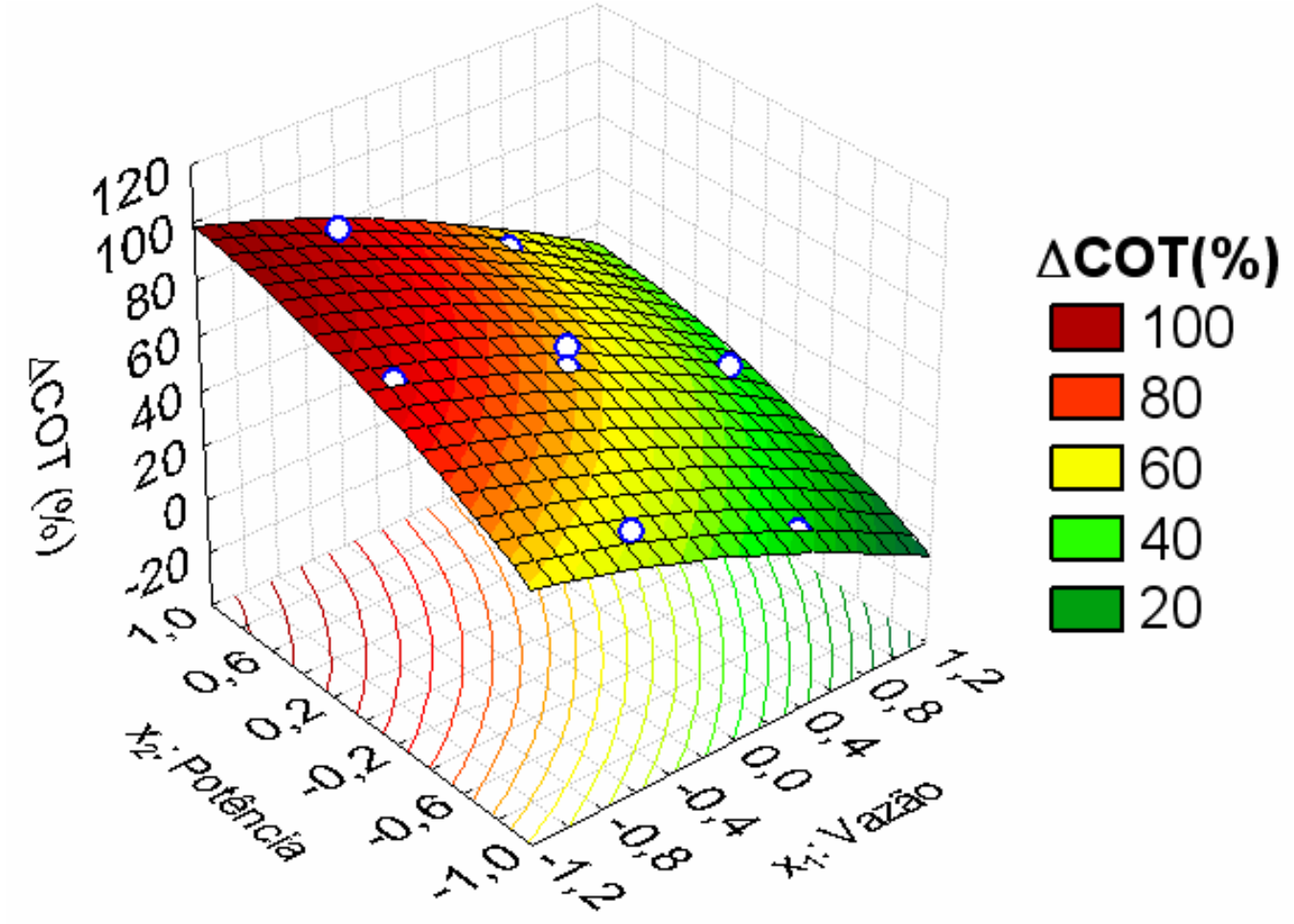

Figura 78 - Superfície de resposta para o plano experimental Doehlert.

No domínio experimental estudado, a eficiência de remoção de COT é afetada fortemente pelas variáveis consideradas no estudo: vazão e potência total das lâmpadas utilizadas.

A vazão, representada pela variável codificada $x_{1}$, apresenta um efeito negativo sobre a variável $\triangle \mathrm{COT}(\%)$, ou seja, o aumento dessa variável implica $o$ decréscimo de remoção de COT. Quanto maior é a vazão, o tempo de residência dos reagentes no reator diminui, levando a uma menor eficiência de remoção.

Por outro lado, a potência, representada pela variável codificada $\mathrm{x}_{2}$, apresenta um efeito linear positivo e um efeito quadrático negativo. Os resultados mostram que 
o aumento da potência da lâmpada aumenta a taxa de remoção de COT, mas que esta variável tem sua importância decrescente à medida que seu valor aumenta.

O diagrama de Pareto da Figura 79 mostra que os efeitos mais importantes são os efeitos principais 1 (vazão) e 2 (potência), pois o valor de p está abaixo de 0,05 . Portanto, nos níveis experimentados, o efeito de interação 12 e os efeitos quadráticos não foram significativos.

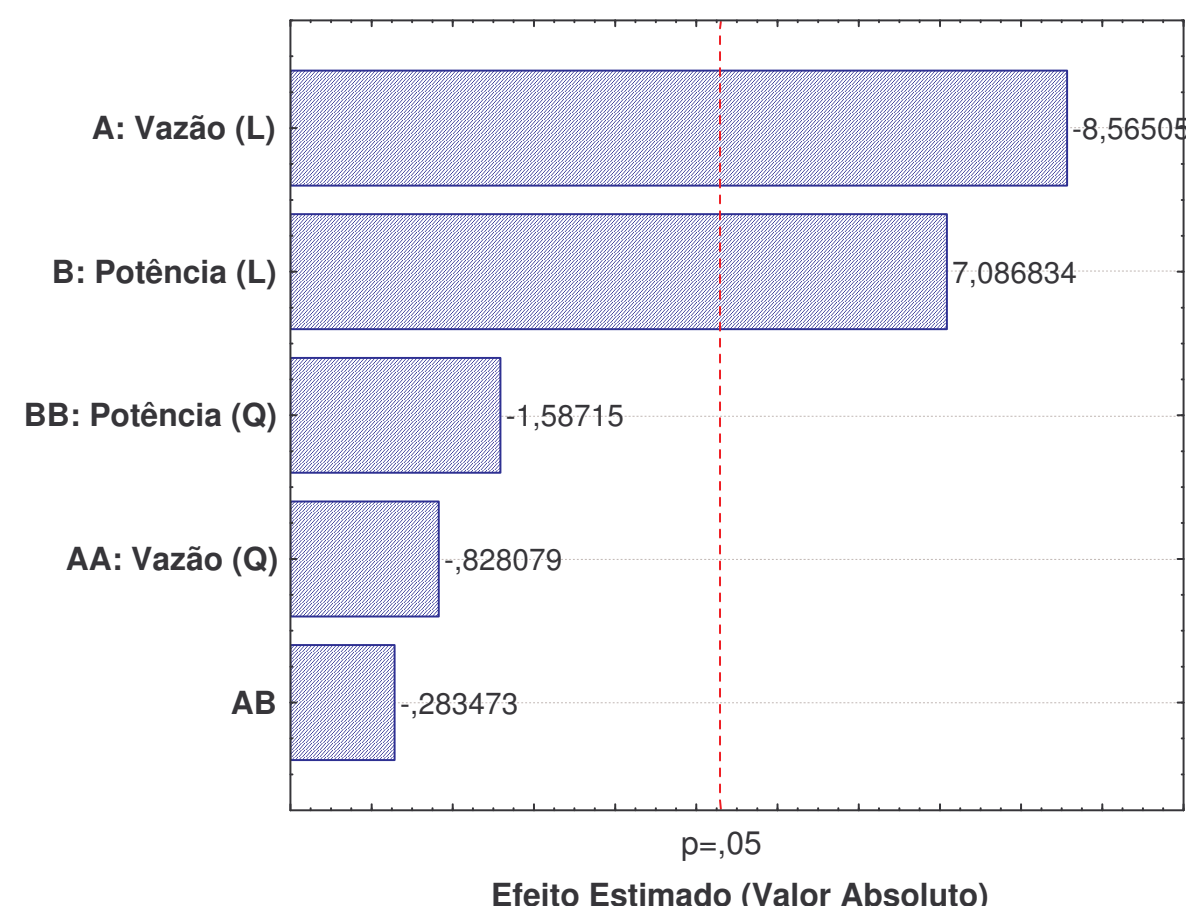

Figura 79 - Diagrama de Pareto dos efeitos padronizados

O modelo proposto mostrou-se satisfatório para o ajuste dos dados experimentais. Através da análise de variância, pôde-se obter a percentagem de variação explicada pela regressão, isto é, a razão entre a soma quadrática devida à regressão e a soma quadrática total (98\%).

Tabela 35 - ANOVA para o modelo proposto ( $\triangle$ COT $\left.=b_{0}+b_{1} x_{1}+b_{2} x_{2}+b_{11} x_{1}+b_{22} x_{2}+b_{12} x_{1} x_{2}\right)$

\begin{tabular}{|c|c|c|c|}
\hline & SQ & № g.l. & MQ \\
\hline x1 (L) regressão - R & 2054,083 & 1 & 2054,083 \\
\hline x1 (Q) regressão - $R$ & 19,200 & 1 & 19,200 \\
\hline x2 (L) regressão - R & 1406,250 & 1 & 1406,250 \\
\hline X2 (Q) regressão - $R$ & 70,533 & 1 & 70,533 \\
\hline x1 x2 regressão - $R$ & 2,250 & 1 & 2,250 \\
\hline Falta de Ajuste - faj & 28,167 & 1 & 28,167 \\
\hline Erro puro - ep & 56,000 & 2 & 28,000 \\
\hline Total & 3636,483 & 8 & \\
\hline
\end{tabular}

Onde: SQ: soma quadrática, gl: grau de liberdade, MQ: média quadrática

A máxima variação explicável (razão entre soma quadrática devida à regressão e falta de ajuste e a soma quadrática total = 
$\left.\frac{S Q_{R}+S Q_{f a j}}{S Q_{\text {Total }}}=\frac{2054,083+19,200+1406,250+70,533+28,167}{3636,483}\right)$ é $98,5 \%$. O valor da

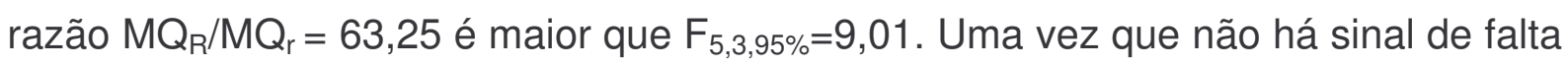
de ajuste, confirmada pelo valor de $M Q_{\mathrm{faj}} / \mathrm{MQ}_{\mathrm{ep}}=1,79<\mathrm{F}_{1,2,95 \%}=18,51$, isto indica que a regressão é significativa.

Experimentos no ponto central foram realizados para avaliar erros experimentais associados ao processo, preparação das amostras e análises. $O$ gráfico mostrado na Figura 80 apresenta a variação de COT em função do tempo para os três ensaios realizados no ponto central. O erro para medida COT no sistema contínuo, estimado a partir do cálculo médio do desvio padrão (Tabela 36), foi de $0,58 \mathrm{mgC} \mathrm{L}^{-1}$ com coeficiente médio de variação de aproximadamente $19 \%$.
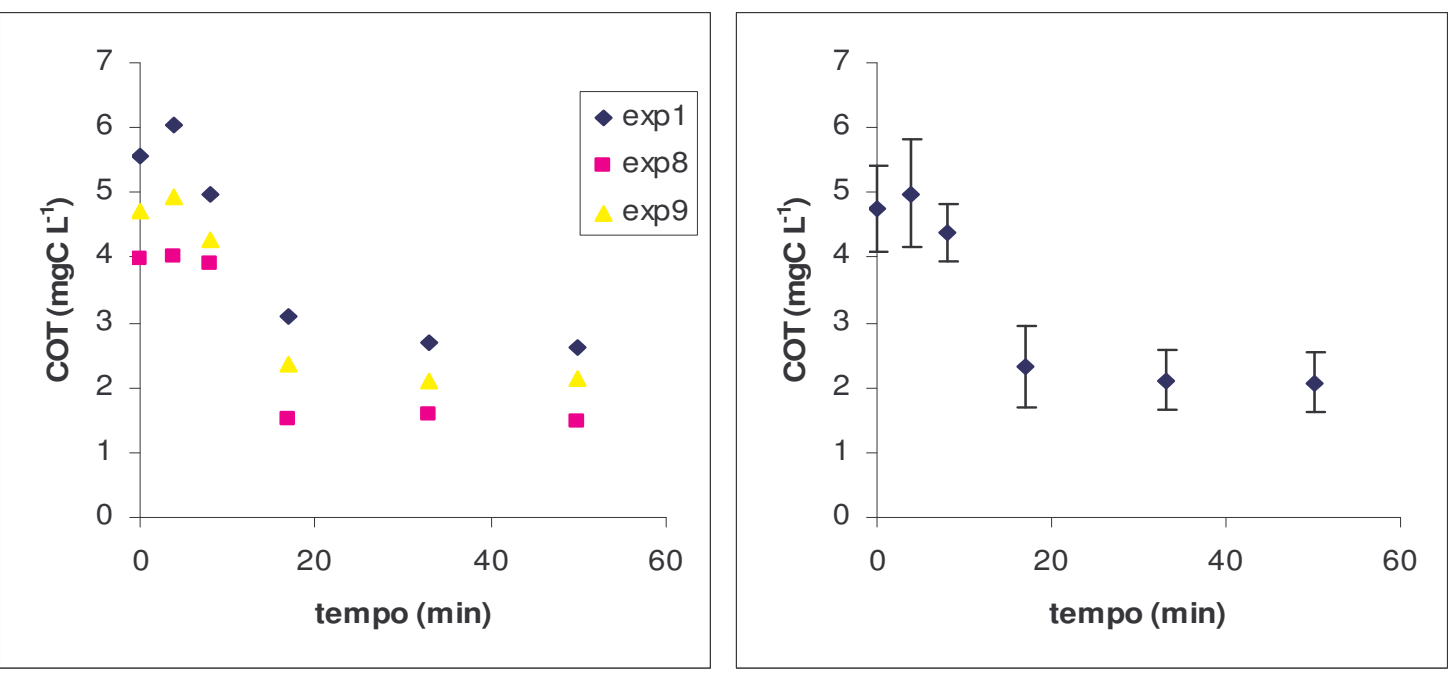

Figura 80 - Análise do erro experimental no ponto central. Condições experimentais: ver Tabela 34.

Tabela 36 - Resultados de COT versus tempo medidos no $4^{\circ}$ compartimento para os ensaios no ponto central

\begin{tabular}{|c|c|c|c|c|c|c|}
\hline $\begin{array}{l}\text { Tempo } \\
\text { (min) }\end{array}$ & $\begin{array}{c}\operatorname{exp1} \\
4^{\circ} \mathrm{cp} \\
\left(\mathrm{mgC} \mathrm{L}^{-1}\right)\end{array}$ & $\begin{array}{c}\operatorname{exp8} \\
4^{\circ} \mathrm{cp} \\
\left(\mathrm{mgC} \mathrm{L}^{-1}\right)\end{array}$ & $\begin{array}{c}\operatorname{exp9} \\
4^{\circ} \mathrm{cp} \\
\left(\mathrm{mgC} \mathrm{L}^{-1}\right)\end{array}$ & $\begin{array}{c}\text { Média } \\
\left(\mathrm{mgC} \mathrm{L}^{-1}\right)\end{array}$ & $\begin{array}{c}\text { Desv. Padrão } \\
\left(d_{p}\right) \\
\left(m g C L^{-1}\right)\end{array}$ & $\begin{array}{c}\text { 100*Desv. Padrão/Média } \\
\left.\text { Coef. Variação (c } \mathbf{c}_{\mathrm{v}}\right) \\
(\%)\end{array}$ \\
\hline 0 & 5,55 & 3,97 & 4,73 & 4,75 & 0,65 & 14 \\
\hline 4 & 6,03 & 4,01 & 4,94 & 4,99 & 0,82 & 16 \\
\hline 8 & 4,98 & 3,89 & 4,29 & 4,39 & 0,45 & 10 \\
\hline 17 & 3,08 & 1,53 & 2,37 & 2,32 & 0,63 & 27 \\
\hline 33 & 2,69 & 1,58 & 2,09 & 2,12 & 0,46 & 22 \\
\hline 50 & 2,62 & 1,48 & 2,12 & 2,07 & 0,47 & 23 \\
\hline \multicolumn{5}{|c|}{ Valores médios } & 0,58 & 19 \\
\hline
\end{tabular}

Os experimentos realizados no reator fotoquímico contínuo, projetado com base no reator em sistema batelada, apresentaram desempenho médio de 57\% de remoção de COT. Este resultado indica que processos de foto-oxidação em sistemas contínuos visando a aplicação industrial é possível. 


\section{CONCLUSÕES}

Com base nos objetivos propostos e nos resultados obtidos no desenvolvimento do trabalho apresentado obtiveram-se as seguintes conclusões:

$\mathrm{O}$ processo $\mathrm{UV} / \mathrm{H}_{2} \mathrm{O}_{2}$ é eficiente para o tratamento de efluentes industriais aquosos contendo oligômeros de propileno. Em geral, após o término da reação fotoquímica, mais que $80 \%$ do carbono orgânico total (COT) é removido mesmo em efluente altamente concentrado. Conforme observado, por exemplo no ensaio BE113 com baixo COT (Efluente E1, $\mathrm{COT}_{0}=7,8 \mathrm{mgC} \mathrm{L}^{-1}, \mathrm{P}=125 \mathrm{~W},\left[\mathrm{H}_{2} \mathrm{O}_{2}\right]=2,0 \mathrm{mM}, \alpha$ $=9, T=30^{\circ} \mathrm{C}, t_{R}=120 \mathrm{~min}$ ) no qual a remoção de COT atingiu $87 \%$ ao final da reação. Para efluente altamente concentrado, no ensaio BE4-12 (Efluente E4, COT 0195 $\mathrm{mgC} \mathrm{L}{ }^{-1}, \mathrm{P}=125 \mathrm{~W},\left[\mathrm{H}_{2} \mathrm{O}_{2}\right]=53 \mathrm{mM}, \alpha=9, \mathrm{~T}=30^{\circ} \mathrm{C}, \mathrm{t}_{\mathrm{R}}=180 \mathrm{~min}$ ) foi mostrado remoção de $88 \%$ do carbono orgânico.

A partir dos experimentos realizados em sistema fotoquímico operando em batelada, conclui-se que quanto maior o valor de energia luminosa aplicada ao sistema, maior é a eficiência de remoção de COT. Para o volume de reator empregado, a potência da fonte de luz atinge saturação para lâmpada de potência de 125W. O uso de potências maiores implica um excedente de fótons, ou seja, desperdício de energia.

Nos casos dos efluentes E1, E2 e E3, que contêm baixo teor de matéria orgânica, um curto tempo de reação, aproximadamente 20 minutos, é requerido para alcançar níveis satisfatórios de remoção. No entanto, para o caso do efluente E4, de alto teor de matéria orgânica inicial, maiores tempos de reação são necessários, em torno de 80 minutos.

No domínio experimental investigado, a influência da variável $\mathrm{H}_{2} \mathrm{O}_{2}$ é positiva, pois variando a concentração de peróxido do nível menor para o maior, a taxa inicial de remoção aumenta. Apesar disso, considerando maiores tempos de remoção, a variável $\mathrm{H}_{2} \mathrm{O}_{2}$, passa a ter uma influência menor sobre o percentual de remoção de COT. Com proporção alta de peróxido de hidrogênio (a em torno de 9), o percentual de remoção máximo é atingido em todos os sistemas, não havendo necessidade de aumentar este valor, uma vez que seu efeito sobre o sistema é pouco relevante.

O sistema apresentou-se pouco sensível à variação de temperatura investigada. 
Com base nos resultados, a remoção de quantidades significativas de COT no efluente de baixo COT inicial (E1, E2, E3) após tratamento via sistema $U V / \mathrm{H}_{2} \mathrm{O}_{2}$, a custos menores do que o custo da água potável desmineralizada, é economicamente possível. Embora a aplicação do sistema $U \mathrm{UV} / \mathrm{H}_{2} \mathrm{O}_{2}$ para fins de reúso seja tecnicamente viável para alta e baixo teor de matéria orgânica, ela não é economicamente atrativa para efluentes contendo alto teor de matéria orgânica. Uma análise de custo preliminar mostra que o circuito de água de processo com o reúso pode reduzir os custos de captação de água em $50 \%$.

Pelas características dos efluentes depois de tratados, eles estão aptos tecnicamente a serem reusados, especialmente os efluentes E1, E2 e E3. No entanto, a avaliação do efluente tratado a fim de verificar se a água atende especificações para fins de reúso e o estudo da sua alocação dentro das unidades de processo fazem partem das próximas atividades do estudo, não incluídas neste trabalho.

O uso de um modelo de rede neural para a descrição da oxidação fotoquímica dos efluentes mostrou resultados promissores, uma vez que o modelo é capaz de descrever o comportamento do sistema complexo de reações dentro da faixa de condições experimentais adotadas.

Através de simulações baseadas no modelo, uma análise de sensibilidade do sistema de reação em relação às variáveis críticas foi efetuada por meio de superfície de resposta. Estas informações são úteis para a otimização do processo bem como para o projeto e aumento de escala de reatores fotoquímicos para uso industrial.

Os resultados de DTR indicam que o projeto do reator contínuo é satisfatório, visto que este pode ser representado por modelos ideais. Com isso, na etapa a seguir pode-se testar o reator para a finalidade a que ele se destina: os processos fotoquímicos. Os processos de foto-oxidação em sistemas contínuos visando a aplicação industrial é possível, uma vez o desempenho médio de remoção de COT foi de $57 \%$, para vazão de $50 \mathrm{~L} / \mathrm{h}$ e potência aplicada ao sistema de $1000 \mathrm{~W}$.

A superfície de resposta para os ensaios fotoquímicos contínuos obtida através do plano experiemntal Doehlert demonstra que quanto maior é a vazão, o tempo de residência dos reagentes no reator diminui, levando a uma menor eficiência de remoção. Os resultados mostram também que o aumento da potência 
da lâmpada aumenta a taxa de remoção de COT, mas que esta variável tem sua importância decrescente à medida que seu valor aumenta.

Para trabalhos futuros, sugere-se testar a eficiência do reator contínuo para remoção de poluentes modelos tal como fenol, largamente estudado na literatura, aplicando-se outros tipos de Processos Oxidativos Avançados, por exemplo: fotoFenton e $\mathrm{H}_{2} \mathrm{O}_{2} / \mathrm{O}_{3} / \mathrm{hv}$. Este estudo permitiria comparar os resultados com os já publicados na literatura. Sugere-se também avaliar a aplicabilidade do reator fotoquímico contínuo para outros tipos de efluentes industriais. 


\section{REFERÊNCIAS BIBLIOGRÁFICAS}

ACERO, J.L.; BENITEZ, F.J.; HEREDIA, J. B.; LEAL, A.I. Chemical treatment of cork-processing wastewaters for potential reuse. Journal Of Chemical Technology and Biotechnology, v. 79, p. 1065-1072, 2004.

ALFANO, O.M.; BAHNEMANN, D.;CASSANO, A.E.; DOLLERT, R. GOSLICH, R. Photocatalysis in water environments using artificial and solar light. Catalysis Today, v. 58, p. 199-230, 2000.

ANDREOZZI, R.; CAPRIO, V.; INSOLA, A.; MAROTTA, R. Advanced Oxidation Process (AOP) for Water Purification and Recovery. Catalysis Today, v. 53, p. 5159, 1999.

ARSLAN, I.; BALCIOGLU, I.A.; TUHKANEN, T.; BAHNEMANN, D. $\mathrm{H}_{2} \mathrm{O}_{2} / \mathrm{UV}$ and $\mathrm{Fe}^{2+} / \mathrm{H}_{2} \mathrm{O}_{2} / \mathrm{UV}$-c versus $\mathrm{TiO}_{2} / \mathrm{UV}$ - $A$ treatment for reactive dye wastewater. Journal of Environmental Engineering, v. 126, p. 903-911, 2000.

BARROS NETO, B.; SCARMÍNIO, I.S.; BRUNS, R.E. Como Fazer Experimentos: Pesquisa e Desenvolvimento da Ciência e Indústria. $2^{\underline{a}}$ edição. Campinas: Editora da UNICAMP, 2002. 401 p.

BELTRÁN, F.J.; GONZÁLEZ, M.; GONZÁLEZ, J. F. Industrial wastewater advanced oxidation: Part 1. UV radiation in the presence and absence of hydrogen peroxide. Water Research, v. 31, p. 2405-2414, 1997.

BENITEZ, F. J.; HEREDIA, J. B.; ACERO, J.L.; GONZALEZ, T. Degradation of protocatechuic acid by two advanced oxidation processes: ozone/UV radiation and $\mathrm{H}_{2} \mathrm{O}_{2} / \mathrm{UV}$ radiation. Water Research, v.30, p. 1597-1604, 1996.

BES-PIÁ, A.; MENDOZA-ROCA, J.A.; ROIG-ALCOVER, L.; IBORRA-CLAR, A.; IBORRA-CLAR, M.I.; ALCAINA-MIRANDA, M.I. Comparison between nanofiltration and ozonation of biologically treated textile wastewater for its reuse in the industry. Desalination, v. 157; p. 81-86, 2003.

BIGDA, R. Consider Fenton's Chemistry for Wastewater Treatment. Chem. Eng. Prog., p.62-66, dec.1995.

BOLTON, J.R.; BIRCHER, K.G.; TUMAS, W.; TOLMAN, C. A. A Figures-of-Merit for the Technical Development and Application of Advanced Oxidation Technologies for Both Electric- and Solar-Driven Systems. Pure Appl. Chem., v. 73, p. 627-637, 2001. 
BOLTON, J.R.; BIRCHER, K.G.; TUMAS, W.; TOLMAN, C.A. Figures-of-Merit for Technical Development and Application of Advanced Oxidation Processes. Journal of Advanced Oxidation Technologies, 1995.

BRASIL. Agência Nacional de Águas, ANA. Cadernos de Recursos Hídricos: Disponibilidade e Demandas de Recursos Hídricos no Brasil. Brasília:

SPR/SUM/SAS, 2005. 123p. Disponível em: < http://www.ana.gov.br >. Acesso em: 18 fev. 2006.

BRASIL. Comitê PCJ. Estabelece mecanismos e sugere os valores para a cobrança pelo uso dos Recursos Hídricos nas Bacias Hidrográficas dos rios Piracicaba, Capivari e Jundiaí e dá outras providências. Deliberação Conjunta no025/05, de 21 de outubro de 2005 alteradas pela Deliberação Conjunta nº 027/05, de 30 de novembro de 2005. Disponível em:

$<$ http://www.ana.gov.br/GestaoRecHidricos/CobrancaUso >. Acesso em: 04 maio 2006.

BRASIL. CONAMA. Resolução nํ357, de 17 de março de 2005. Dispõe sobre a classificação dos corpos de água e diretrizes ambientais para o seu enquadramento, bem como estabelece as condições e padrões de lançamento de efluentes, e dá outras providências. Disponível em:

<http://www.mma.gov.br/conama/res/res05/res35705.pdf >. Acesso em: 29 set. 2006.

BRASIL. Lei no 9.433, de 08 de janeiro de 1997. Institui a Política Nacional de Recursos Hídricos, cria o Sistema Nacional de Gerenciamento de Recursos Hídricos, regulamenta o inciso XIX do art. 21 da Constituição Federal, e altera o art. $1^{\circ}$ da Lei no 8.001, de 13 de março de 1990, que modificou a Lei no 7.990, de 28 de dezembro de 1989. Disponível em:

<http://www.ana.gov.br/Legislacao/docs/lei9433.pdf>. Acesso em: 20 abr. 2006.

BRASIL. Lei no 9.605 de 12 de fevereiro de 1998. Dispõe sobre as sanções penais e administrativas derivadas de condutas e atividades lesivas ao meio ambiente, e dá outras providências.Disponível em:

<http://www.presidencia.gov.br/ccivil/Leis/L9605.htm>. Acesso em: 29 set. 2006.

BRASIL. Lei no 9.984, de 17 de julho de 2000. Dispõe sobre a criação da Agência Nacional de Águas - ANA, entidade federal de implementação da Política Nacional de Recursos Hídricos e de coordenação do Sistema Nacional de Gerenciamento de Recursos Hídricos, e dá outras providências. Disponível em:

<http://www.ana.gov.br/Legislacao/docs/lei9984.pdf>. Acesso em: 20 abr. 2006.

BRASIL. Ministério da Ciência e Tecnologia. Pesquisa estuda o potencial de reúso da água nas indústrias de Manaus como instrumento para 0 desenvolvimento sustentável. 2006. Disponível em 
$<$ http://www.canalciencia.ibict.br/pesquisas/pesquisa.php?ref pesquisa=128>.

Acesso em: 20 maio 2006.

BRAUN, A. M.; OLIVEROS, E. How to evaluate photochemical methods for water treatment. Wat. Sci. Tech., v. 35, p. 17-23, 1997.

BRAUN, A.M.; JAKOB, L.; OLIVEIROS, E.; NASCIMENTO, C. A. O. Up-Scaling Photochemical Reactions. Adv.Photchem., New York, v. 18, p. 235-313, 1993.

BRAUN, A.M.; MAURETTE, M.T.; OLIVEROS E. Photochemical Tecnology. Chichester, West Sussex, England, New York: John Wiley \& Sons Inc., 1991. 559 p.

BUXTON, G.V.; GREENSTOCK, C.L.; HELMAN, W.P.; ROSS, A.B. Critical review of rate constants for reaction of hydrated electrons hydrogen atoms and hydroxyl radicals $\left({ }^{\circ} \mathrm{OH} /{ }^{\circ} \mathrm{O}\right)$ in aqueous solution. J. Phys. Chem. Ref. Data, v.17, p. 513-886, 1988.

CARETTI, C.; LUBELLO, C. Wastewater disinfection with PAA and UV combined treatment: a pilot plant study. Water Research, v. 37, p. 2365-2371, 2003.

CASSANO, A. E.; MARTIN, C.A.; BRANDI, R.J.; ALFANO, T.O.M. Photoreactor Analysis and Design: Fundamentals and Applications. Ind. Eng. Chem. Res., v. 34, p. 2155-2201, 1995.

CATER, S.R.; STEFAN, M.I.; BOLTON, J.R.; SAFARZADEH-AMIRI, A. UV/ $\mathrm{H}_{2} \mathrm{O}_{2}$ Treatment of Methyl tert-Butyl Ether in Contaminated Waters. Environ. Sci. Technol., v.34, p. 659-662, 2000.

CAVICCHIOLI, A.; GUTZ, I.G.R. O Uso de Radiação Ultravioleta para o PréTratamento de Amostras em Análise Inorgânica. Química Nova, v. 26, p. 913-921, 2003.

CHANG, P. B. L.; YOUNG, T. M. Kinetics of Methyl Tert-Butyl Ether Degradation And by-Product Formation during UV/Hydrogen Peroxide Water Treatment. Water

Research, v. 34, p. 2233-2240, 2000.

$\mathrm{CHU}, \mathrm{W}$. Modeling the quantum yield of herbicide 2,4-D decay in $\mathrm{UV} / \mathrm{H}_{2} \mathrm{O}_{2}$ process.

Chemosphere, v. 44, p.935-941, 2001.

CISNEROS, R. L.; ESPINOZA, A. G.; LITTER, M. I. Photodegradation of an azo dye of textile industry. Chemosphere, v. 48, p. 393-399, 2002. 
CLARKE, N.; KNOWLES, G. High purity water using $\mathrm{H}_{2} \mathrm{O}_{2}$ and UV radiation. Effluent and Water Treatment Journal, v. 22, p. 335-341, 1982.

COSTA, D.M.A; BARROS JÚNIOR, A.C. Avaliação da Necessidade do Reúso de Águas Residuais. Holos, Ano 21, p. 81-101, set. 2005.

CRITTENDEN, J. C.; HU, S.; HAND, D. W.; GREEN S. A. A Kinetic model for $\mathrm{H}_{2} \mathrm{O}_{2} / \mathrm{UV}$ process in a completely mixed batch reactor. Water Research, v.33, p. 2315-2328, 1999.

DANESHVAR, B, N.; RABBANIA, M.; MODIRSHAHLAC, N.; BEHNAJADY, M.A. Photooxidative degradation of Acid Red 27 in a tubular continuous-flow photoreactor: influence of operational parameters and mineralization products. Journal of Hazardous Materials B, v.118, p.155-160, 2005.

DANTAS, M.A.R.; MELO, H.N.S.; NETO, C.O.A. Aplicação de Traçadores em Filtro Anaeróbios para Avaliação das Características Hidrodinâmicas. In: CONGRESSO INTERAMERICANO DE ENGENHARIA SANITÁRIA E AMBIENTAL, XXVII, 2000, Porto Alegre. Anais do XXVII Congresso Interamericano de Engenharia Sanitária e Ambiental. Rio de Janeiro: ABES, 2000. v. 1, p. 1-12.

Deliberação CEIVAP № 008, de 06 de dezembro de 2001. CEIVAP. Dispõe sobre a implantação da cobrança pelo uso de Recursos Hídricos na Bacia do rio Paraíba do Sul a partir de 2002, Resende. RESENDE (MUNICÍPIO). Disponível em: <http://www.ana.gov.br/GestaoRecHidricos/CobrancaUso>. Acesso em: 04 maio 2006.

Deliberação CEIVAP no 015, de 04 de novembro de 2002. CEIVAP. Dispõe sobre medidas complementares para a implantação da cobrança pelo uso de Recursos Hídricos na Bacia do rio Paraíba do Sul a partir de 2002, em atendimento à Deliberação CEIVAP no 08/2001. RESENDE (MUNICÍPIO). Disponível em: $<$ http://www.ana.gov.br/GestaoRecHidricos/CobrancaUso >. Acesso em: 04 maio 2006.

DEZOTTI, M. Técnicas de Controle Ambiental em Efluente Líquidos: Processos Oxidativos Avançados - Parte 1. Rio de Janeiro: PEQ/COPPE/UFRJ, 2000. Capítulo 5, 20 p. Apostila de curso.

DURHAM, B.; BOURBIGOT, M.; PANKRATZ, T. Membranes as pretreatment to desalination in wastewater reuse: operating experience in the municipal and industrial sectors. Desalination, v. 138, p. 83-90, 2001. 
EINSCHLAG, F. S. G.; LOPEZ, J.; CARLOS, L.; CAPPARELLI, A. L.; BRAUN, A. M.; OLIVEROS, E. Evaluation of the Efficiency of Photodegradation of Nitroaromatics Applying the UV/ $\mathrm{H}_{2} \mathrm{O}_{2}$ Technique. Environ. Sci. Technol., v.36, p. 3936-3944, 2002.

EINSCHLAG, F.S.G.; CARLOS, L.; CAPPARELLI; A.L. Competition kinetics using the $\mathrm{UV} / \mathrm{H}_{2} \mathrm{O}_{2}$ process: a structure reactivity correlation for the rate constants of hydroxyl radicals toward nitroaromatic compounds. Chemosphere, v. 53, p 1-7, 2003.

ESCOLA POLITÉCNICA DA UNIVERSIDADE DE SÃO PAULO. Diretrizes para apresentação de dissertações e teses. $3^{\text {an }}$ ed. São Paulo, 2006. 103 p.

ESPULGAS, S.; JIMÉNEZ, J.; CONTRERAS, S.; PASCUAL, E.; RODRÍGUEZ, M. Comparison of different advanced oxidation processes for phenol degradation. Water Research, v. 36, p. 1034-1042, 2002.

Environmental Protection Agency, EPA. Handbook: Advanced Photochemical Oxidation Processes. Estados Unidos. Cincinnatti: Dec. 1998. 97 p. (EPAl6251R981004).

FELIZATTO, M. R. ETE CAGIF: Projeto Integrado de Tratamento Avançado e Reúso Direto de Águas Residuárias. In: CONGRESSO BRASILEIRO DE ENGENHARIA

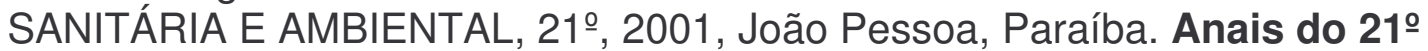
Congresso Brasileiro de Engenharia Sanitária e Ambiental. Rio de Janeiro: ABES, 2001. p. 1-17. CD-ROM.

FIESP; CIESP. Conservação e Reúso de Água: Manual de Orientações para o Setor Industrial. 2004. v.1. Disponível em: $<$ www.fiesp.com.br/download/publicacoes meio ambiente/reuso.pdf $>$. Acesso em: 1 fev. 2006.

FOGLER, H.S. Elements of Chemical Reaction Engineering. Third Edition. Upper Saddle River, N.J.: Prentice Hall, 1999. 967 p. (International Series in the Physical and Chemical Engineering Sciences).

FURTADO, M.R. Tarifas em alta incentivam os primeiros projetos na indústria. Revista Química e Derivados, edição no 444, dez. 2005. Disponível em: http://www.quimica.com.br/revista/qd444/reuso1.html>. Acesso em: 10 out. 2006.

GALINDO, C.; KALT, A. UV/ $\mathrm{H}_{2} \mathrm{O}_{2}$ oxidation of monoazo dyes in aqueous media: a kinetic study. Dyes and Pigments, v. 40, p. 27-35, 1998. 
GIROTO, J.A. Estudo do processo de degradação fotoquímica de soluções aquosas de álcool polivinílico. 2002. 106 p. Dissertação (Mestrado em Engenharia Química). Universidade de São Paulo. São Paulo, 2002.

GLAZE, W.H.; LAY, Y.; KANG, J. Advanced Oxidation Processes. A kinetic model for oxidation of 1,2-dibromo-3-chloropropane in water by combination of hydrogen peroxide and UV radiation. Ind. Eng. Chem. Res., v. 34, p. 2314-2323, 1995.

GLAZE, W.H.; LAY, Y.; KANG, J. The chemistry of water treatment use involving ozone, hydrogen peroxide and ultraviolet radiation. Ozone Sci. and Engrg. v. 9, p. 335-342, 1987.

GONÇALVES, A. C. Tratamento de Efluentes Contendo Cianeto Livre Através do Sistema $\mathrm{H}_{2} \mathrm{O}_{2} /$ UV. 2004. 206 p. Tese (Doutorado em em Ciência dos Materiais e Metalurgia). Pontifícia Universidade Católica do Rio de Janeiro. Rio de Janeiro, 2004.

GOSLICH, R.; DILLERT, R.; BAHNEMANN, D. Solar water treatment: Principles and reactors. Wat. Sci. Tech., v. 35, n. 4, p. 137-148, 1997.

HAM, F. M.; KOSTANIC, I. Principles of neurocomputing for science and engineering. New York: McGraw Hill, 2001. 642 p.

HANCOCK, F.E. Catalytic strategies for industrial water re-use. Catalysis Today, v.53, p. 3-9, 1999.

HIMMELBLAU, D.M.; BISCHOFF, K.B. Process Analysis and Simulation:

Deterministic Systems. New York: J. Wiley \& Sons, 1968. 348 p.

INCE, N.H.; TEZCANLI, G. Treatability of textile dye-bath effluents by advanced oxidation: preparation for reuse. Wat. Sci. Tech., v. 40, p. 183-190, 1999.

INTO, M.; JONSSON, A.S.; LENGDEN, G. Reuse of industrial wastewater following treatment with reverse osmosis. Journal of Membrane Science, v. 242, p. 21-25, 2004.

JUANG, L-C; TSENG, D-H; YANG, S-C. Treatment of petrochemical wastewater by $\mathrm{UV} / \mathrm{H}_{2} \mathrm{O}_{2}$ photodecomposed system. Wat. Sci. Tech., v. 36, p. 357-365, 1997.

LECLERC, J.-P.; CLAUDEL, S.; LINTZ, H. -G.; POTIER, O.; ANTOINE, B. Photochemical Processes for Water Treatment. Chem. Rev., v.93, p.159-166, 1993. 
LEGRINI, O.; OLIVEROS, E.; BRAUN, A. M. Photochemical Processes for Water Treatment. Chem. Rev., v.93, p.159-166, 1993.

LEITE, A.M.F. Reúso de Água na Gestão Integrada de Recursos Hídricos. 2003. 116 p. Dissertação (Mestrado em Planejamento e Gestão Ambiental) - Universidade Católica de Brasília. Distrito Federal, 2003.

LEVENSPIEL, O. Engenharia das Reações Químicas. São Paulo: Edgard Blucher, 1974. $2 \mathrm{~V}$.

LEVENSPIEL, O. Mixed Models to Represent Flow of Fluids through Vessels. The Canadian Journal of Chemical Engineering, p. 135-138, August, 1962.

LEOPOLDO, P.R.; HERRERA, O.M. Perdas de água tratada no sistema de abastecimento público de Botucatu. Energia na Agricultura, v. 12, p. 26-44, 1997.

LINDÉN, L.Å.; RABEK, J.F. KACZMAREK, H.; KAMINSKA, A.; SCOPONI, M. Photooxidative degradation of polymers by $\mathrm{HO}^{\bullet}$ and $\mathrm{HO}_{2}{ }^{\bullet}$ radicals generated during the photolysis of $\mathrm{H}_{2} \mathrm{O}_{2}, \mathrm{FeCl}_{3}$, and Fenton reagents. Coordination Chemistry Reviews, v. 125, p. $195-218,1993$.

LIRA, D.C.B.; AGUIAR, D.T., TEIXEIRA, A.C.S.C.; WILL, I.B.S.; GUARDANI, R.; NASCIMENTO, C.A.O. ESTUDO DE TRATAMENTO FOTOQUÍMICO $\left(\mathrm{UV} / \mathrm{H}_{2} \mathrm{O}_{2}\right)$ PARA REUSO DE ÁGUAS DE PROCESSOS CONTENDO CONTAMINANTES ORGÂNICOS. In: Congresso Brasileiro de Engenharia Química COBEQ, XVI, 2006a, Santos, Brasil. CD-ROM.

LIRA, D.C.B.; AGUIAR, D.T.; WILL, I.B.S.; GUARDANI, R.; NASCIMENTO, C.A.O. Aplicação do Sistema UV/ $\mathrm{H}_{2} \mathrm{O}_{2}$ para o Reuso de Água de Processo de uma Indústria Petroquímica. In: Encontro Sobre Aplicações Ambientais de Processos Oxidativos Avançados EPOA, III, 2005, Campinas, Brasil. Livro de Resumos. Campinas: Prisma Printer Gráfica e Editora Ltda, 2005a. POA-12.

LIRA, D.C.B.; NASCIMENTO, L; WILL, I.B.S.; CHIAVONE-FILHO, O.; GUARDANI, R.; NASCIMENTO, C.A.O. Fotodegradação em Sistema Contínuo de um Efluente Industrial Contendo Polímeros Visando o Reuso. Revista Petro \& Química, ㄲo 281, p. 71-77, fev. 2006b.

LIRA, D.C.B.; WILL, I.B.S.; GUARDANI, R.; NASCIMENTO, C.A.O. Modeling the Kinetics of a Petrochemical Industrial Wastewater Treatment Using Artificial Neural Networks. In: Mercosur Congress on Chemical Engineering ENPROMER, $2^{\text {nd }}, 2005$, Rio de Janeiro, Brasil. Proceedings. Rio de Janeiro: E-papers Serviços Editoriais, 2005b. Code 465. CD-ROM. 
MADWAR, K.; TARAZI, H. Desalination techniques for industrial wastewater reuse. Desalination, v. 152, p. 325-332, 2002.

MANCUSO, P.C.S; SANTOS, H.F. Reúso de Água. São Paulo: Ed. Barueri: Manole, 2003. $579 \mathrm{p}$.

MARCUCCI, M.; TOGNOTTI, L. Reuse of wastewater for industrial needs: the Pontedera case. Resources Conservation and Recycling, v. 34, p. 249-259, 2002.

MARTIN, A. D. Interpretation of residence time distribution data. Chemical Engineering Science, v. 55, p. 5907-5917, 2000.

MIERZWA, J. C. O uso racional e o reúso como ferramentas para o gerenciamento de águas e efluentes na indústria: estudo de caso da kodak brasileira. 2002. 367p. Tese (Doutorado em Engenharia Hidráulica e Sanitária) Escola Politécnica, Universidade de São Paulo. São Paulo, 2002.

MIERZWA, J. C.; HESPANHOL, I. Programa para o gerenciamento de águas e efluentes nas indústrias visando o uso racional e o reúso. Revista de Engenharia Ambiental, v. 4, p. 11-15, 1999.

MINAS GERAIS. Decreto no 44.046, de 13 de junho de 2005. Regulamenta a cobrança pelo uso de recursos hídricos de domínio do Estado. Disponível em: $<$ http://www.ana.gov.br/GestaoRecHidricos/CobrancaUso/ ARQSLegal/Geral/Legislacoes Estaduais/MG/Decreto 44046 - 13Jun05.doc >. Acesso em: 20 set. 2006.

NASCIMENTO, C. A. O.; OLIVEROS, E.; BRAUN, A. M. Neural Network Modelling for Photochemical Processes. Chem. Eng. Processing, v.33, p.319-324, 1994.

NEWTON, D.; SOLT, G. (Ed.). Water Use and Reuse. UK: Institution of Chemical Engineers, 1994. 92 p.

PACHECO, J. R.; PERALTA-ZAMORA, P. G. Integração de processos físicoquímicos e oxidativos avançados para remediação de percolado de aterro sanitário (chorume). Eng. Sanit. Ambient., v.9, p.306-311, 2004.

PAREEK,V. K.; BRUNGS, M. P.; ADESINA, A. A. Continuous Process for Photodegradation of Industrial Bayer Liquor. Ind. Eng. Chem. Res., v. 40, p. 51205125, 2001. 
PARSONS, S. Advanced Oxidation Processes for Water and Wastewater

Treatment. London: IWA Publishing, 2004. 368 p.

PIMENTEL, C.A.F.; RABINOVICH, S.V.; YAMAMURA, P. Elementos da Teoria de Erros. São Paulo: Instituto de Física da USP, 1985. 44 p. Apostila.

SANTOS, F. N. dos. Otimização do Reúso Industrial através da Metodologia "Pinch". 2004. 201 p. Dissertação (Mestrado em Engenharia Hidráulica e Sanitária) - Escola Politécnica, Universidade de São Paulo. São Paulo, 2004.

SANZ, J.; LOMBRAÑA, J.I.; DE LUIS, A.M..; RODRÍGUEZ, R. UV/ $\mathrm{H}_{2} \mathrm{O}_{2}$ Chemical Oxidation for High Loaded Effluents: Application to Surfactants in Water. Kinetics of Decomposition and Biodegradability. In: INTERNATIONAL CONGRESS OF CHEMICAL AND PROCESS ENGINEERING, 15 $5^{\text {th }}, 2002$, Praha, Czech Republic. CHISA 2002 : proceedings. Praha, 2002b. "Paginação sem indicação". CD-ROM.

SANZ, J.; LOMBRAÑA, J.I.; DE LUIS, A.M.; ORTUETA, M.; VARONA, F. Analysis of the Efficiency of Three Advanced Oxidation Processes on the Generation of Hydroxyl Radicals in the Treatment of Phenol. In: INTERNATIONAL CONGRESS OF CHEMICAL AND PROCESS ENGINEERING, 15 ${ }^{\text {th }}, 2002$, Praha, Czech Republic. CHISA 2002 : proceedings. Praha, 2002a. "Paginação sem indicação". CD-ROM.

SÃO PAULO (ESTADO). Lei nํ 12.183, de 29/12/2005. Dispõe sobre a cobrança pela utilização dos recursos hídricos do domínio do Estado de São Paulo, os procedimentos para fixação dos seus limites, condicionantes e valores e dá outras providências. Disponível em:

$<$ http://www.ana.gov.br/GestaoRecHidricos/CobrancaUso/ ARQSLegal/Geral/Legislacoes Estaduais/SP/Lei-12183-05.pdf>. Acesso em: 20 set. 2006.

SASSAKI, R.A. Distribuição de Tempos de Residência em Sistemas

Alimentados com Vazão Variável. 2005. 89 p. Dissertação (Mestrado em Engenharia Civil) - Universidade Federal do Rio De Janeiro. Rio de Janeiro, 2005.

SAUTOUR, M.; ROUGET, A.; DANTIGNY, P.; DIVIES, C.; BENSOUSSAN, M. Application of Doehlert design to determine the combined effects of temperature, water activity and $\mathrm{pH}$ on conidial germination of Penicillium chrysogenum. Journal of Applied Microbiology, v. 91, p. 900-906, 2001.

SERPONE, N. Relative photonic efficiencies and quantum yields in heterogeneous photocatalysis. J. Photochem. Photobiol. A., v. 104, p. 1, 1997.

SHEN,Y. S.; WANG, D. K. Development of photoreactor design equation for the treatment of dye wastewater by $\mathrm{UV} / \mathrm{H}_{2} \mathrm{O}_{2}$ process. Journal of Hazardous Materials B, v. 89, p. 267-277, 2002. 
SONUNE, A.; GHATE, R. Developments in wastewater treatment methods.

Desalination, v. 167, p. 55-63, 2004.

SOUILAH, O.; AKRETCHE, D.E.; AMARA, M. Water reuse of an industrial effluent by means of Electrodeionisation. Desalination, v. 167, p. 49-54, 2004.

STEFAN, M.I.; BOLTON, J.R. Mechanism of degradation of 1,4-dioxane in dilute aqueous solution using the UV/hydrogen peroxide process. Environ. Sci. Technol., v. 32, p. 1588-1595, 1998.

STEPNOWISKI, P.; SIEDLECKA, E.M.; BEHREND, P.; JASTORFF, B. Enhanced photodegradation of contaminants in petroleum refinery wastewater. Water Research, v. 36, p. 2167-2172, 2002.

STRAPASSON, R. Valorização do polipropileno através de sua mistura e reciclagem. 2004. 84 p. Dissertação (Mestrado) - Universidade Federal do Paraná. Curitiba, 2004,

SUN, L.; BOLTON, J.R. Determination of the quantum yield for the photochemical generation of hydroxyl radicals in TiO2 suspensions. J. Phys. Chem., v. 100, p. 4127-4134, 1996.

TEIXEIRA, A. C. S. C.; GUARDANI, R.; NASCIMENTO, C. A. O. Photo-fenton remediation of wastewaters containing silicones: Experimental study and neural network modeling. Chemical Engineering \& Technology, v. 27, p. 800-810, 2004.

TEIXEIRA, C.P.A.B.; JARDIM, W.F. Processos Oxidativos Avançados: Conceitos Teóricos. Campinas: Universidade Estadual de Campinas - Unicamp, ago. 2004. 83 p. Caderno Temático Volume 03.

TELÊMACO, E.P; LIRA, D.C.B.; NASCIMENTO, L; WILL, I.B.S.; CHIAVONE-FILHO, O.; GUARDANI, R.; NASCIMENTO, C.A.O. Fotodegradação através do Processo Oxidativo avançado de um efluente industrial contendo polímeros. Revista Petro \& Química, no 278, p. 83-88, nov. 2005.

VENKATADRI, R.; PETERS, R. W. Chemical Oxidation Technologies: UV Light/Hydrogen Peroxide, Fenton's Reagent, Titanium Dioxide Assisted Photocatalysis. Hazardous Waste and Hazardous Materials, v. 10, p. 107-149, 1993.

VERHOEVEN, J. W. Glossary of Terms Used in Photochemistry: IUPAC Recommendations 1996. Pure Appl. Chem., v. 68, p. 2223-2286, 1996. 
WILL, I.B. S. Estudo da utilização de reatores fotoquímicos solares para a degradação de efluentes industriais contendo compostos orgânicos tóxicos. 2003. 142 p. Tese (Doutorado em Engenharia Química) - Escola Politécnica, Universidade de São Paulo. São Paulo, 2003. 
APÊNDICE A - Código do programa de simulação da Curva de COT x tempo a partir dos pesos obtidos por rede neural:

getf('rn3.sci');

COTo=6; // conc. inicial de orgânicos no sistema , mg/L

$\mathrm{T}=30 ; / /$ Temperatura, $\stackrel{\circ}{\mathrm{C}}$

$\mathrm{H} 2 \mathrm{O} 2=8$; // conc. peróxido, mg/L

Pot $=125$;

$\mathrm{h}=1 ; / /$ passo de integração, min

//COT(1)=COTo;

$\mathrm{i}=1 ;$ // índice para o contador de tempo

$\mathrm{t}(\mathrm{i})=0 ; / /$

$\mathrm{fd}=$ mopen('saida.txt',''w');

mfprintf(fd,'ttt COT $\backslash n ')$;

while $\mathrm{t}(\mathrm{i})<120$

$\mathrm{X}=[\mathrm{t}$ (i) H2O2 Pot T COTo]; // X é o vetor das vars. de entrada da RN

$\mathrm{COT}(\mathrm{i})=\mathrm{rn} 3(\mathrm{X})$; // Cálculo do COT(t) pela rede neural em mg/L

$\mathrm{i}=\mathrm{i}+1$;

$t(i)=t(i-1)+h$;

end

mfprintf(fd, '\%flt \%fln',t,COT);

mclose('all');

function $[\mathrm{mrA}]=\mathrm{rn} 3(\mathrm{X})$

// Calcula a taxa de remoção de COT partir da conc. em t e demais condições

$\mathrm{Nl}=5 ; \mathrm{NO}=1 ; \mathrm{NH}=5$;

$\mathrm{MIN}=0.1 ; \mathrm{MAX}=0.9 ; / /$ intervalo de normalização

// valores mínimos e máximos das variáveis de entrada e saída:

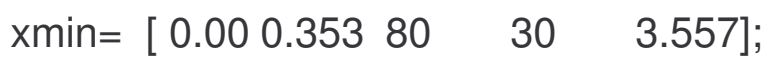

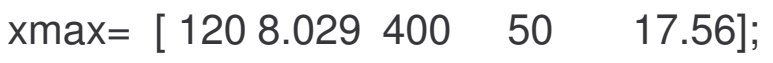

$y \min =[0.428] ; y \max =[17.56]$;

// pesos para a camada oculta, $\mathrm{Wij}, \mathrm{i}=1, \ldots \mathrm{n},+$ bias; $\mathrm{j}=1, \ldots \mathrm{NH}$ :

$\mathrm{WIJ}=\left[\begin{array}{lllll}-10.5713 & -22.64229 & -0.9155144 & -33.56388 & 7.103121 ;\end{array}\right.$

$\begin{array}{lllll}0.3269661 & -2.783576 & -2.599961 & -1.110888 & 1.97874 ; \\ -1.04822 & -10.07075 & -6.699554 & 1.805975 & 19.49778 ; \\ 4.53 E-02 & -0.4693396 & -2.04 E-02 & -0.5353283 & 1.365828 ;\end{array}$


$1.176103 \quad 2.971581 \quad 5.34 \mathrm{E}-02 \quad 4.721505 \quad-9.800926$;

$\left.\begin{array}{lllll}-0.6287023 & 0.8827205 & 0.2680593 & -5.42 E-02 & 0.9651506\end{array}\right]$;

// pesos para a camada de saída, $\mathrm{Wjk}, \mathrm{j}=1, \ldots \mathrm{NH},+$ bias; $\mathrm{k}=1, \ldots$ nsaídas:

WJK= [5.832086; -10.75539; 3.613932; 3.28927; -1.531322; -0.4355897];

//Etapa 1: normalização das variáveis de entrada:

for $\mathrm{i}=1$ :NI

$$
X N(i)=(X(i)-x \min (i)) /(x \max (i)-x \min (i))^{\star}(M A X-M I N)+M I N ;
$$

end

//Etapa 2: calc. soma ponderada para camada oculta:

$\mathrm{XN}(\mathrm{NI}+1)=1$;

SOMA1=XN"*WIJ; //soma para cada um dos NH neurônios da camada oculta //Etapa 3: cal. das saídas (sigmoidal):

for $\mathrm{j}=1 \mathrm{NH}$

$$
\text { SAI1(j) }=1 /(1+\exp (-\operatorname{SOMA} 1(\mathrm{j}))) \text {; }
$$

end

//Etapa 4: calc. soma ponderada para camada saída:

$\mathrm{SAI} 1(\mathrm{NH}+1)=1$;

SOMA2=SAI1'*WJK; //soma para cada um dos NO neurônios de saída

//Etapa5: calc. das saídas da rede

for $k=1$ :NO

$$
\mathrm{YN}(\mathrm{k})=1 /(1+\exp (-\mathrm{SOMA} 2(\mathrm{k}))) ;
$$

end

//Etapa 6: desnormalização da saída:

for $k=1: N O$

$$
\mathrm{y}(\mathrm{k})=(\mathrm{YN}(\mathrm{k})-\mathrm{MIN})^{\star}(\mathrm{ymax}(\mathrm{k})-\mathrm{ymin}(\mathrm{k})) /(\mathrm{MAX}-\mathrm{MIN})+\mathrm{ymin}(\mathrm{k}) ;
$$

end

$\mathrm{mrA}=\mathrm{y}(1)$

endfunction 
APÊNDICE B - Cálculo de modelos de distribuição de tempos de residência

Modelo A: Modelo de escoamento para quatro reatores de mistura perfeita e volumes iguais em série, considerando região de zona morta para cada reator.

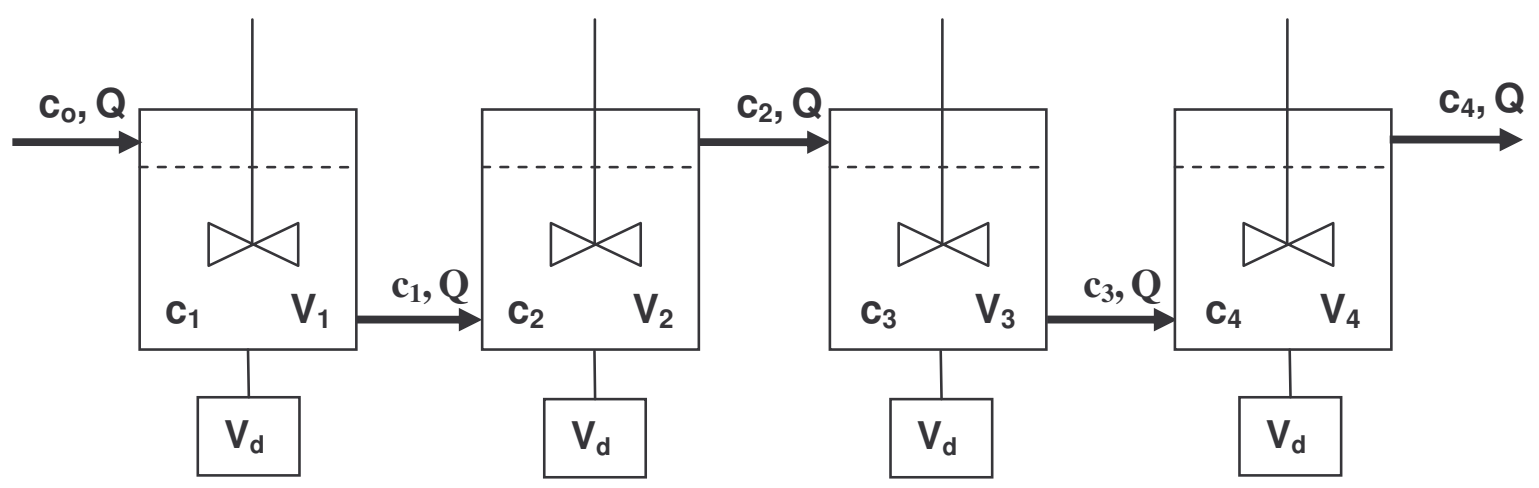

Figura C.1 - Representação do modelo proposto

Condições iniciais:

$\mathrm{V}_{1}=\mathrm{V}_{2}=\mathrm{V}_{3}=\mathrm{V}_{4}=\mathrm{V}_{\mathrm{a}}$ (volume da zona ativa reacional em cada reator)

$\mathrm{V}_{1}+\mathrm{V}_{2}+\mathrm{V}_{3}+\mathrm{V}_{4}=\mathrm{V}_{\mathrm{aT}}$ (volume da zona ativa reacional total)

$V_{d}$ (volume de zona morta em cada reator)

$\mathrm{V}_{\mathrm{dT}}$ (volume de zona morta total)

Com base na Figura C.1, pode-se escrever o seguinte balanço material do traçador para o i-nésimo tanque:

$V_{a} \frac{d c_{i}}{d t}+Q \cdot c_{i}=Q \cdot c_{i-1}$

Como o tempo de injeção é muito pequeno face à duração do experimento e do tempo médio de residência, pode-se considerar que o traçador é adicionado na forma de pulso instantâneo no primeiro tanque no instante $\mathrm{t}=0$. Portanto:

$c_{i \neq 0}=0$

$c_{i=0}=c^{o} \frac{V}{Q} \delta(t)$

Em que:

$$
\begin{aligned}
& c^{\circ}=\text { concentração média de traçador se distribuído uniformemente no sistema } \\
& \mathrm{V}=\text { volume total no sistema }=\mathrm{V}_{\mathrm{aT}}+\mathrm{V}_{\mathrm{dT}}=4 \cdot\left(\mathrm{V}_{\mathrm{a}}+\mathrm{V}_{\mathrm{d}}\right) \\
& \delta(\mathrm{t})=\text { função pulso unitário } \begin{cases}\delta(t)=0 & t=0 \\
\delta(t)=\infty & t \neq 0\end{cases}
\end{aligned}
$$

Aplicando a transformada de Laplace à Eq.( 43 ) e às condições iniciais Eq.(44) e Eq.(45), obtém-se: 


$$
\begin{aligned}
& s \cdot V_{a} \cdot \bar{c}_{i}+Q \cdot \bar{c}_{i}=Q \cdot \bar{c}_{i-1} \\
& \bar{c}_{i \neq 0}=0 \\
& \bar{c}_{i=0}=c^{o} \frac{V}{Q}
\end{aligned}
$$

De (46), tem-se:

$$
\bar{c}_{i}=\frac{\bar{c}_{i-1}}{s\left(\frac{V_{a}}{Q}\right)+1}
$$

Então, resolvendo a Eq.(49) para todos os tanques:

$$
\begin{array}{lll}
\bar{c}_{4}=\frac{\bar{c}_{3}}{s\left(\frac{V_{a}}{Q}\right)+1} & (50) & \bar{c}_{2}=\frac{\bar{c}_{1}}{s\left(\frac{V_{a}}{Q}\right)+1} \\
\bar{c}_{3}=\frac{\bar{c}_{2}}{s\left(\frac{V_{a}}{Q}\right)+1} & (52) & \bar{c}_{1}=\frac{c^{o} \frac{V}{Q}}{s\left(\frac{V_{a}}{Q}\right)+1}
\end{array}
$$

Portanto, para o último tanque $(\mathrm{i}=4)$ :

$$
\bar{c}_{4}=\frac{c^{o} \frac{V}{Q}}{\left[s\left(\frac{V_{a}}{Q}\right)+1\right]^{4}}
$$

A transformada inversa de Laplace é aplicada resultando na seguinte equação:

$$
c_{4}=c^{o} \frac{V}{Q} \cdot \frac{1}{3 !}\left(\frac{Q}{V_{a}}\right)^{4} \cdot t^{3} \cdot e^{-\frac{Q}{V_{a}} \cdot t}
$$

Usando $\theta=\frac{t}{\tau} \quad$ e $\tau=\frac{V}{Q}$, tem-se $\mathrm{E}(\theta)$ para quatro reatores de mistura perfeita e volumes iguais em série considerando região de zona morta para cada reator:

$$
E(\theta)=\frac{c_{4}}{c^{o}}=\frac{1}{6} \cdot\left(\frac{V}{V_{a}}\right)^{4} \cdot \theta^{3} \cdot e^{-\frac{V}{V_{a}} \cdot \theta}
$$

Para $V_{d}=0$ (sem região de zona morta), $V=4^{*} V_{a}$. Portanto $\circ E(\theta)$ obtido será o equivalente ao modelo de quatro reatores de mistura perfeita e volumes iguais em série (Modelo B). 


\section{APÊNDICE C - Estudo de Viabilidade Econômica}

\section{Estudo de Viabilidade Econômica - CASO A}

\begin{tabular}{|l|r|}
\hline Custo da água potável $\left(\mathrm{R} \$ / \mathrm{m}^{3}\right)$ - captação de água da rede de abastecimento - CAP & 1,40 \\
\hline Custo da água potável desmineralizada $\left(\mathrm{R} \$ / \mathrm{m}^{3}\right)$ - conforme item 1.2 - Justificativa - CAD & 7,40 \\
\hline Custo de tratamento $\left(\mathrm{R} \$ / \mathrm{m}^{3}\right)$ - CT & 7,40 \\
\hline Custo de descarte $\left(\mathrm{R} \$ / \mathrm{m}^{3}\right)$ - cobrança de recursos hídricos do CEIVAP (item 2.1.2) - CD & 0,02 \\
\hline
\end{tabular}

\begin{tabular}{|l|r|r|r|r|}
\hline \multicolumn{9}{|l|}{ DADOS DOS EFLUENTES } & \multicolumn{3}{|l|}{} \\
\hline \multirow{2}{*}{ Variáveis } & BE1-13 & BE2-15 & BE2-17 & \\
\cline { 2 - 6 } & E1 & E2-E3 & E2-E3 & \\
\hline COTo $\left(\mathrm{mg} \mathrm{L}^{-1}\right)$ & 7,8 & 7,8 & 8,5 & \\
\hline$\Delta$ COT $\%)$ & 84 & 71 & 71 & \\
\hline$\Delta$ COT $\left(\mathrm{mg} \mathrm{L}^{-1}\right)$ & 6,59 & 5,53 & 6,00 & \\
\hline Tempo de tratamento $(\mathrm{min})$ & 20 & 20 & 30 & \\
\hline $\mathrm{P}(\mathrm{W})$ & 125 & 125 & 125 & \\
\hline$\alpha(\mathrm{mgH} 2 \mathrm{O} 2 / \mathrm{mgC})$ & 9 & 5 & 10 & \\
\hline
\end{tabular}

\begin{tabular}{|c|c|c|c|}
\hline $\begin{array}{l}\text { CENARIO 1: ANTES DA IMPLAN } \\
\text { Vazão de água consumida }\left(\mathrm{m}^{3} / \mathrm{h}\right)\end{array}$ & $\frac{R \text { min }}{\min }$ & $\frac{G \cup A D E P}{\max }$ & ROCESSO \\
\hline $\mathrm{E} 1$ & 2,0 & 2,5 & $Q_{E 1}$ \\
\hline E2 e E3 & 2,0 & 2,5 & $Q_{E 2 / E 3}$ \\
\hline E4 & 0,024 & 0,024 & $Q_{E 4}$ \\
\hline Total & 4,024 & 5,024 & $Q_{T}=Q_{E 1}+Q_{E 2 / E 3}+Q_{E 4}$ \\
\hline Vazão de Reposição $\left(\mathrm{m}^{3} / \mathrm{h}\right)^{*}$ & 4,426 & 5,526 & $Q_{R}=1,1^{*} Q_{T}$ \\
\hline \multicolumn{4}{|l|}{${ }^{*}$ perda de água no sistema $=10 \%$} \\
\hline Custo $(\mathrm{R} \$ /$ ano $)$ ANTES & $\min$ & $\max$ & \\
\hline Custo captação e desmi ( $\mathrm{R} \$ /$ ano) & 286936,95 & 358243,35 & $\$_{C A D}=C A D^{*} Q_{R}$ \\
\hline Custo de descarte (R\$/ano) & 775,51 & 968,23 & $\$_{D}=C D^{*} Q_{R}$ \\
\hline TOTAL & 287712,46 & 359211,58 & $\$_{T}=\$_{C A D}+\$_{D}$ \\
\hline
\end{tabular}

CENARIO 2: APOS IMPLANTAÇAO DE REUSO DE AGUA DE PROCESSO (cf. Fig 57)

\begin{tabular}{|c|c|c|c|}
\hline Vazão de água reusada $\left(\mathrm{m}^{3} / \mathrm{h}\right)$ & $\min$ & $\max$ & \\
\hline Próprio processo $(\mathrm{E} 1)$ & 2,0 & 2,5 & $Q_{E 1}$ \\
\hline Água para desmineralização (E2 e E3) & 2,0 & 2,5 & $\mathrm{Q}_{\mathrm{E} / \mathrm{E} 3}$ \\
\hline E4 & 0,024 & 0,024 & $\mathrm{Q}_{\mathrm{E} 4}$ \\
\hline Total para reúso & 4,0 & 5,0 & $Q_{T}=Q_{E 1}+Q_{E 2 / E 3}$ \\
\hline Vazão de Reposição $\left(\mathrm{m}^{3} / \mathrm{h}\right)^{*}$ & 0,426 & 0,526 & $Q_{R}=0,1^{*} Q_{T}+1,1 Q_{E 4}$ \\
\hline \multicolumn{4}{|l|}{${ }^{*}$ perda de água no sistema $=10 \%$} \\
\hline Custo $(\mathrm{R} \$ / \mathrm{ano})$ APÓS & $\min$ & $\max$ & \\
\hline Custo captação e desmi (R\$/ano) & 132760,95 & 165523,35 & 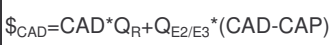 \\
\hline Custo de tratamento (R\$/ano) & 259296,00 & 324120,00 & $\$_{\mathrm{CT}}=\mathrm{CT}^{*} \mathrm{Q}_{\mathrm{T}}$ \\
\hline Custo de descarte (R\$/ano) & 74,71 & 92,23 & $\$_{D}=C D^{*} Q_{R}$ \\
\hline TOTAL & 392131,66 & 489735,58 & $\$ \$_{T}=\$ C A D+\$ D$ \\
\hline
\end{tabular}

\section{ECONOMIA ENTRE CENARIOS $1 \mathrm{E} 2$}

ECONOMIA TOTAL (\%) ECONOMIA CAPTAÇÃO/DESMIN. (\%)
$-36 \%$

$54 \%$
$-36 \%=1$-APOS/ANTES $54 \%=1$-APÓS/ANTES 
Estudo de Viabilidade Econômica - CASO B

\begin{tabular}{|l|r|}
\hline Custo da água potável $\left(\mathrm{R} \$ / \mathrm{m}^{3}\right)$ - captação de água da rede de abastecimento - CAP & 1,40 \\
\hline Custo da água potável desmineralizada $\left(\mathrm{R} \$ / \mathrm{m}^{3}\right)$ - conforme item 1.2 - Justificativa - CAD & 7,40 \\
\hline Custo de tratamento $\left(\mathrm{R} \$ / \mathrm{m}^{3}\right)$ - CT & 4,40 \\
\hline Custo de descarte $\left(\mathrm{R} \$ / \mathrm{m}^{3}\right)$ - cobrança de recursos hídricos do CEIVAP (item 2.1.2) - CD & 0,02 \\
\hline
\end{tabular}

\begin{tabular}{|l|l|r|r|r|}
\hline \multicolumn{5}{|c|}{ DADOS DOS EFLUENTES } \\
\hline \multirow{2}{*}{ Variáveis } & BE1-13 & BE2-15 & BE2-17 & \\
\cline { 2 - 6 } & E1 & E2-E3 & E2-E3 & \\
\hline COTo $\left(\mathrm{mg} \mathrm{L}^{-1}\right)$ & 7,8 & 7,8 & 8,5 & \\
\hline$\Delta$ COT $\%)$ & 70 & 52 & 57 & \\
\hline$\Delta$ COT $\left(\mathrm{mg} \mathrm{L}^{-1}\right)$ & 5,49 & 4,05 & 4,82 & \\
\hline Tempo de tratamento $(\mathrm{min})$ & 20 & 20 & 30 & \\
\hline $\mathrm{P}(\mathrm{W})$ & 125 & 125 & 125 & \\
\hline$\alpha(\mathrm{mgH} 2 \mathrm{O} 2 / \mathrm{mgC})$ & 9 & 5 & 10 & \\
\hline
\end{tabular}

CENARIO 1: ANTES DA IMPLANTAÇAO DE REUSO DE AGUA DE PROCESSO

\begin{tabular}{|c|c|c|c|}
\hline \multicolumn{4}{|c|}{$\begin{array}{l}\text { CENARIO 1: ANTES DA IMPLANTAÇAO DE REUSO DE AGUA DE PROCESSO } \\
\end{array}$} \\
\hline Vazão de água consumida $\left(\mathrm{m}^{3} / \mathrm{h}\right)$ & $\min$ & $\max$ & \\
\hline \begin{tabular}{|l|l}
$\mathrm{E} 1$ \\
\end{tabular} & 2,0 & 2,5 & $Q_{\mathrm{E} 1}$ \\
\hline E2 e E3 & 2,0 & 2,5 & $\mathrm{Q}_{\mathrm{E} 2 / \mathrm{E} 3}$ \\
\hline E4 & 0,024 & 0,024 & $\mathrm{Q}_{\mathrm{E} 4}$ \\
\hline Total & 4,024 & 5,024 & $Q_{T}=Q_{E 1}+Q_{E 2 / E 3}+Q_{E 4}$ \\
\hline Vazão de Reposição $\left(\mathrm{m}^{3} / \mathrm{h}\right)^{\star}$ & 4,426 & 5,526 & $Q_{R}=1,1^{*} Q_{T}$ \\
\hline \multicolumn{4}{|l|}{ * perda de água no sistema $=10 \%$} \\
\hline Custo $(\mathrm{R} \$ / \mathrm{ano})$ ANTES & $\min$ & $\max$ & \\
\hline Custo captação e desmi ( $\mathrm{R} \$ /$ ano) & 286936,95 & 358243,35 & $\$_{C A D}=C A D * Q_{R}$ \\
\hline Custo de descarte $(\mathrm{R} \$ / \mathrm{ano})$ & 775,51 & 968,23 & $\$_{D}=C D^{*} Q_{R}$ \\
\hline TOTAL & 287712,46 & 359211,58 & $\$_{T}=\$_{C A D}+\$_{D}$ \\
\hline
\end{tabular}

\begin{tabular}{|c|c|c|c|}
\hline \multicolumn{4}{|c|}{ CENARIO 2: APOS IMPLANTAÇAO DE REUSO DE AGUA DE PROCESSO (cf. Fig 57) } \\
\hline Vazão de água reusada $\left(\mathrm{m}^{3} / \mathrm{h}\right)$ & $\min$ & $\max$ & \\
\hline Próprio processo $(\mathrm{E} 1)$ & 2,0 & 2,5 & $Q_{E 1}$ \\
\hline Água para desmineralização (E2 e E3) & 2,0 & 2,5 & $Q_{E 2 / E 3}$ \\
\hline E4 & 0,024 & 0,024 & $\mathrm{Q}_{\mathrm{E} 4}$ \\
\hline Total para reúso & 4,0 & 5,0 & $Q_{T}=Q_{E 1}+Q_{E 2 / E 3}$ \\
\hline Vazão de Reposição $\left(m^{3} / h\right)^{*}$ & 0,426 & 0,526 & $Q_{R}=0,1^{*} Q_{T}+1,1 Q_{E 4}$ \\
\hline \multicolumn{4}{|l|}{ * perda de água no sistema $=10 \%$} \\
\hline Custo (R\$/ano) APÓS & $\min$ & $\max$ & \\
\hline Custo captação e desmi (R\$/ano) & 132760,95 & 165523,35 & $\$_{C A D}=C_{A D}{ }^{*} Q_{R}+Q_{E 2 E 3^{*}}($ CAD-CAP) \\
\hline Custo de tratamento $(\mathrm{R} \$ / \mathrm{ano})$ & 154101,72 & 192627,14 & $\$_{\mathrm{CT}}=\mathrm{CT}^{*} \mathrm{Q}_{\mathrm{T}}$ \\
\hline Custo de descarte (R\$/ano) & 74,71 & 92,23 & $\$_{D}=C D^{*} Q_{R}$ \\
\hline TOTAL & 286937,37 & 358242,72 & $\$_{T}=\$_{C A D}+\$_{D}$ \\
\hline
\end{tabular}

ECONOMIA ENTRE CENARIOS $1 \mathrm{E} 2$

ECONOMIA TOTAL (\%) ECONOMIA CAPTAÇÁO/DESMIN. (\%)

$0 \%$ $0 \%=1$-APÓS/ANTES $54 \%=1$-APÓS/ANTES 
Estudo de Viabilidade Econômica - CASO C

\begin{tabular}{|l|r|}
\hline Custo da água potável $\left(\mathrm{R} \$ / \mathrm{m}^{3}\right)$ - captação de água da rede de abastecimento - CAP & 1,40 \\
\hline Custo da água potável desmineralizada $\left(\mathrm{R} \$ / \mathrm{m}^{3}\right)$ - conforme item 1.2 - Justificativa - CAD & 7,40 \\
\hline Custo de tratamento $\left(\mathrm{R} \$ / \mathrm{m}^{3}\right)$ - CT & 7,40 \\
\hline Custo de descarte $\left(\mathrm{R} \$ / \mathrm{m}^{3}\right)$ - cobrança de recursos hídricos do CEIVAP (item 2.1.2) - CD & 0,02 \\
\hline
\end{tabular}

\begin{tabular}{|l|l|r|r|r|}
\hline \multicolumn{5}{|c|}{ DADOS DOS EFLUENTES } \\
\hline \multirow{2}{*}{ Variáveis } & BE1-13 & BE2-15 & BE2-17 & \\
\cline { 2 - 6 } & E1 & E2-E3 & E2-E3 & \\
\hline COTo $\left(\mathrm{mg} \mathrm{L}^{-1}\right)$ & 7,8 & 7,8 & 8,5 & \\
\hline$\Delta$ COT $\%)$ & 84 & 71 & 71 & \\
\hline$\Delta$ COT $\left(\mathrm{mg} \mathrm{L}^{-1}\right)$ & 6,59 & 5,53 & 6,00 & \\
\hline Tempo de tratamento $(\mathrm{min})$ & 20 & 20 & 30 & \\
\hline $\mathrm{P}(\mathrm{W})$ & 125 & 125 & 125 & \\
\hline$\alpha(\mathrm{mgH} 2 \mathrm{O} 2 / \mathrm{mgC})$ & 9 & 5 & 10 & \\
\hline
\end{tabular}

CENARIO 1: ANTES DA IMPLANTAÇAO DE REUSO DE AGUA DE PROCESSO

\begin{tabular}{|c|c|c|c|}
\hline \multicolumn{4}{|c|}{ CENARIO 1: ANTES DA IMPLANTAÇAO DE REUSO DE AGUA DE PROCESSO } \\
\hline Vazão de água consumida $\left(\mathrm{m}^{3} / \mathrm{h}\right)$ & $\min$ & $\max$ & \\
\hline E1 & 2,0 & 2,5 & $Q_{\mathrm{E} 1}$ \\
\hline E2 e E3 & 2,0 & 2,5 & $\mathrm{Q}_{\mathrm{E} 2 / \mathrm{E} 3}$ \\
\hline E4 & 0,024 & 0,024 & $Q_{\mathrm{E} 4}$ \\
\hline Total & 4,024 & 5,024 & $Q_{T}=Q_{E 1}+Q_{E 2 / E 3}+Q_{E 4}$ \\
\hline Vazão de Reposição $\left(\mathrm{m}^{3} / \mathrm{h}\right)^{*}$ & 4,426 & 5,526 & $Q_{R}=1,1^{*} Q_{T}$ \\
\hline \multicolumn{4}{|l|}{ * perda de água no sistema $=10 \%$} \\
\hline Custo $(\mathrm{R} \$ / \mathrm{ano})$ ANTES & $\min$ & $\max$ & \\
\hline Custo captação e desmi ( $R \$ / a n o)$ & 286936,95 & 358243,35 & $\$_{C A D}=C A D^{*} Q_{R}$ \\
\hline Custo de descarte (R\$/ano) & 775,51 & 968,23 & $\$_{D}=C D^{*} Q_{R}$ \\
\hline TOTAL & 287712,46 & 359211,58 & $\$ \$_{T}=\$ C A D+\$ D$ \\
\hline
\end{tabular}

CENARIO 3: APOS IMPLANTAÇAO DE REUSO DE AGUA DE PROCESSO (reúso direto)

\begin{tabular}{|c|c|c|c|}
\hline Vazão de água reusada $\left(\mathrm{m}^{3} / \mathrm{h}\right)$ & $\min$ & $\max$ & \\
\hline Próprio processo $(\mathrm{E} 1)$ & 2,0 & 2,5 & $Q_{E 1}$ \\
\hline Próprio processo (E2 e E3) & 2,0 & 2,5 & $Q_{E 2 / E 3}$ \\
\hline E4 & 0,024 & 0,024 & $Q_{E 4}$ \\
\hline Total para reúso & 4,0 & 5,0 & $Q_{T}=Q_{E 1}+Q_{E 2 / E 3}$ \\
\hline Vazão de Reposição $\left(\mathrm{m}^{3} / \mathrm{h}\right)^{*}$ & 0,426 & 0,526 & $Q_{R}=0,1^{*} Q_{T}+1,1 Q_{E 4}$ \\
\hline \multicolumn{4}{|l|}{ * perda de água no sistema $=10 \%$} \\
\hline Custo (R\$/ano) APÓS & $\min$ & $\max$ & \\
\hline Custo captação e desmi ( $\mathrm{R} \$ / \mathrm{ano})$ & 27640,95 & 34123,35 & $\$_{C A D}=C A D^{*} Q_{R}$ \\
\hline Custo de tratamento ( $\mathrm{R} \$ / \mathrm{ano})$ & 259296,00 & 324120,00 & $\$_{\mathrm{CT}}=\mathrm{CT}^{*} \mathrm{Q}_{\mathrm{T}}$ \\
\hline Custo de descarte (R\$/ano) & 74,71 & 92,23 & $\$_{D}=C D^{*} Q_{R}$ \\
\hline TOTAL & 287011,66 & 358335,58 & $\$ \$_{T}=\${ }_{C A D}+\$_{D}$ \\
\hline
\end{tabular}

ECONOMIA ENTRE CENARIOS $1 \mathrm{E} 3$

\begin{tabular}{l|r|r|l}
\hline ECONOMIA TOTAL (\%) & $0 \%$ & $0 \%$ & $=1$-APÓS/ANTES \\
\hline ECONOMIA CAPTAÇÄO/DESMIN. (\%) & $90 \%$ & $90 \%$ & $=1$-APÓS/ANTES
\end{tabular}




\section{APÊNDICE D - Resultados Gerais dos Ensaios de DTR}

a $C(A B S)=0,0328 A B S(665 n m)$

${ }^{\text {b }} E(t)=\frac{C(t)}{\int_{0}^{\infty} C(t) d t} \quad$ с $\bar{t}=\int_{0}^{\infty} t \cdot E(t) d t \quad * M_{C}=Q \cdot \int_{0}^{\infty} C(t) d t$

modelo A: 4 CSTR em série

modelo B: 4 CSTR em série com zona morta

${ }^{\mathrm{c}}$ Cálculo da média da distribuição de tempos de residência $\bar{t}$ :

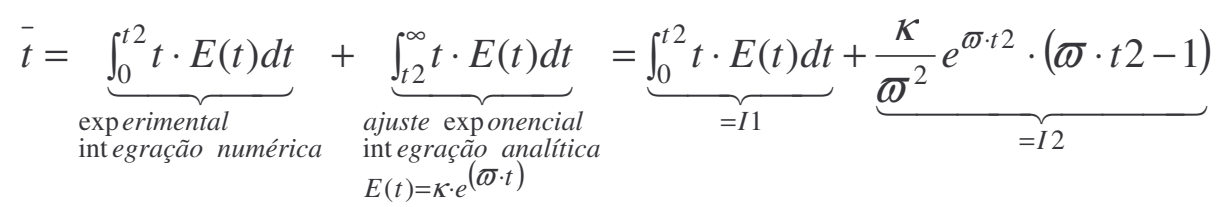

\begin{tabular}{cccccccccccc}
\hline Ensaio & $\mathrm{t} 1(\mathrm{~min})$ & $\mathrm{t} 2(\mathrm{~min})$ & $\theta 1$ & $\theta 2$ & $\mathrm{E}(\mathrm{t} 1)$ & $\mathrm{E}(\mathrm{t} 2)$ & $\mathrm{k}$ & $\omega$ & $\mathrm{I}(\mathrm{min})$ & $\mathrm{I} 2(\mathrm{~min})$ & $t(\mathrm{mim})$ \\
\hline $\mathbf{1}$ & $\mathbf{2 7 , 2}$ & $\mathbf{1 8 , 1}$ & $\mathbf{2 , 9}$ & $\mathbf{2 , 0}$ & $\mathbf{0 , 0 0 2 2 6}$ & $\mathbf{0 , 0 1 7 0 1}$ & $\mathbf{0 , 9 6 1}$ & $-\mathbf{0 , 2 2 3}$ & $\mathbf{8 , 0}$ & $\mathbf{1 , 8}$ & $\mathbf{9 , 8}$ \\
\hline $\mathbf{2}$ & $\mathbf{2 2 , 2}$ & $\mathbf{2 3 , 3}$ & $\mathbf{1 , 9}$ & $\mathbf{2 , 0}$ & $\mathbf{0 , 0 1 6 1 4}$ & $\mathbf{0 , 0 1 2 2 8}$ & $\mathbf{2 , 9 9 3}$ & $-\mathbf{0 , 2 3 6}$ & $\mathbf{1 0 , 3}$ & $\mathbf{1 , 5}$ & $\mathbf{1 1 , 8}$ \\
\hline $\mathbf{3}$ & $\mathbf{4 0 , 8}$ & $\mathbf{3 2 , 6}$ & $\mathbf{2 , 5}$ & $\mathbf{2 , 0}$ & $\mathbf{0 , 0 0 3 9 7}$ & $\mathbf{0 , 0 0 9 6 8}$ & $\mathbf{0 , 3 4 2}$ & $-0,109$ & $\mathbf{1 3 , 8}$ & $\mathbf{3 , 7}$ & $\mathbf{1 7 , 5}$ \\
\hline $\mathbf{4}$ & $\mathbf{4 6 , 2}$ & $\mathbf{5 4 , 4}$ & $\mathbf{1 , 7}$ & $\mathbf{2 , 0}$ & $\mathbf{0 , 0 0 7 9 2}$ & $\mathbf{0 , 0 0 3 7 6}$ & $\mathbf{0 , 5 2 3}$ & $-\mathbf{0 , 0 9 1}$ & $\mathbf{2 2 , 8}$ & $\mathbf{2 , 7}$ & $\mathbf{2 5 , 5}$ \\
\hline $\mathbf{5}$ & $\mathbf{1 3 8 , 7}$ & $\mathbf{1 6 3 , 2}$ & $\mathbf{1 , 7}$ & $\mathbf{2 , 0}$ & $\mathbf{0 , 0 0 2 7 6}$ & $\mathbf{0 , 0 0 1 3 1}$ & $\mathbf{0 , 1 8 9}$ & $-0,030$ & $\mathbf{6 1 , 7}$ & $\mathbf{8 , 5}$ & $\mathbf{7 0 , 2}$ \\
\hline
\end{tabular}


Ensaio 1 data: 6/dez/2005

Tabela D1.1 - Medidas de vazão para Ensaio 1

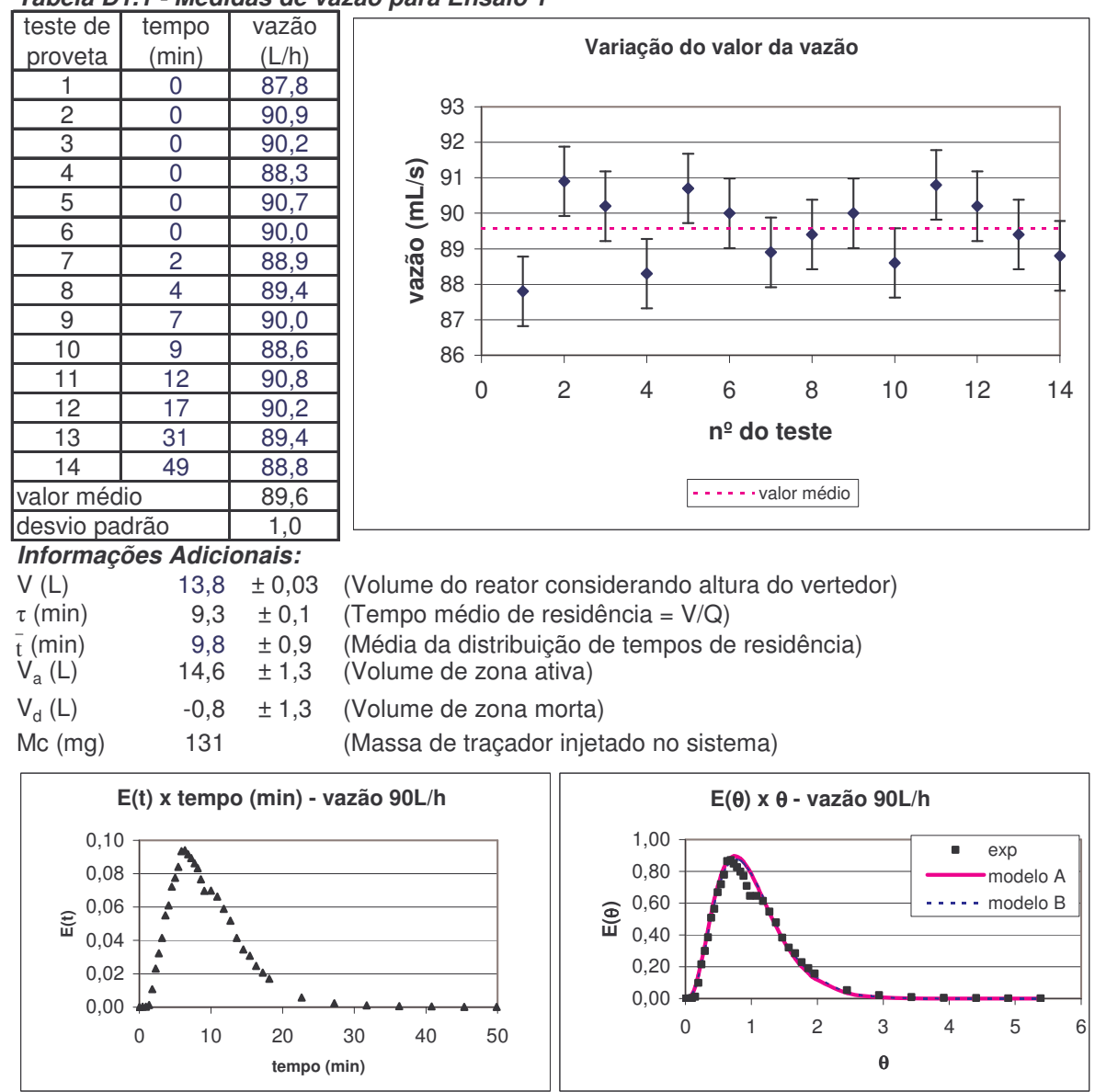

Tabela D1.2 - Dados experimentais obtidos no Ensaio 1 e modelos para ajuste dos dados

\begin{tabular}{|c|c|c|c|c|c|c|c|c|c|}
\hline amostra & $t(\min )$ & $\begin{array}{c}\text { valor ABS } \\
(665 \mathrm{~nm})\end{array}$ & $C(A B S)^{a}$ & $E(t) b$ & $\bar{t}(\min )^{c}$ & $\theta=\mathrm{t} / \tau$ & $E(\theta)=\tau^{\star} E(t)$ & $\begin{array}{c}E(\theta) \\
\text { modelo } A\end{array}$ & $\begin{array}{c}\mathrm{E}(\theta) \\
\text { modelo } \mathrm{B}\end{array}$ \\
\hline 0 & 0,0 & 0,00 & 0,000 & 0,000 & 0,0 & 0,0 & 0,00 & 0,00 & 0,00 \\
\hline 1 & 0,5 & 0,00 & 0,000 & 0,000 & 0,0 & 0,0 & 0,00 & 0,00 & 0,00 \\
\hline 2 & 0,9 & 0,00 & 0,000 & 0,000 & 0,0 & 0,1 & 0,00 & 0,03 & 0,03 \\
\hline 3 & 1,4 & 0,01 & 0,000 & 0,001 & 0,0 & 0,1 & 0,01 & 0,08 & 0,07 \\
\hline 4 & 1,8 & 0,06 & 0,002 & 0,011 & 0,0 & 0,2 & 0,10 & 0,15 & 0,14 \\
\hline 5 & 2,3 & 0,14 & 0,005 & 0,023 & 0,1 & 0,2 & 0,21 & 0,24 & 0,22 \\
\hline 6 & 2,7 & 0,26 & 0,008 & 0,032 & 0,1 & 0,3 & 0,30 & 0,33 & 0,31 \\
\hline 7 & 3,2 & 0,25 & 0,008 & 0,042 & 0,2 & 0,3 & 0,38 & 0,44 & 0,41 \\
\hline 8 & 3,6 & 0,33 & 0,011 & 0,055 & 0,3 & 0,4 & 0,51 & 0,54 & 0,51 \\
\hline 9 & 4,1 & 0,37 & 0,012 & 0,061 & 0,4 & 0,4 & 0,56 & 0,63 & 0,60 \\
\hline 10 & 4,5 & 0,43 & 0,014 & 0,072 & 0,6 & 0,5 & 0,67 & 0,71 & 0,67 \\
\hline 11 & 5,0 & 0,47 & 0,015 & 0,078 & 0,8 & 0,5 & 0,72 & 0,77 & 0,74 \\
\hline 12 & 5,4 & 0,50 & 0,017 & 0,084 & 1,0 & 0,6 & 0,78 & 0,83 & 0,79 \\
\hline 13 & 5,9 & 0,56 & 0,018 & 0,093 & 1,3 & 0,6 & 0,86 & 0,86 & 0,83 \\
\hline 14 & 6,4 & 0,56 & 0,018 & 0,094 & 1,5 & 0,7 & 0,87 & 0,89 & 0,86 \\
\hline 15 & 6,8 & 0,57 & 0,019 & 0,092 & 1,8 & 0,7 & 0,85 & 0,90 & 0,87 \\
\hline 16 & 7,3 & 0,54 & 0,018 & 0,089 & 2,1 & 0,8 & 0,83 & 0,89 & 0,88 \\
\hline 17 & 7,7 & 0,54 & 0,018 & 0,086 & 2,4 & 0,8 & 0,80 & 0,88 & 0,87 \\
\hline 18 & 8,2 & 0,50 & 0,016 & 0,083 & 2,7 & 0,9 & 0,77 & 0,86 & 0,85 \\
\hline 19 & 8,6 & 0,50 & 0,016 & 0,077 & 3,0 & 0,9 & 0,71 & 0,83 & 0,83 \\
\hline 20 & 9,1 & 0,42 & 0,014 & 0,070 & 3,6 & 1,0 & 0,65 & 0,80 & 0,79 \\
\hline 21 & 10,0 & 0,42 & 0,014 & 0,070 & 4,3 & 1,1 & 0,65 & 0,72 & 0,72 \\
\hline 22 & 10,9 & 0,40 & 0,013 & 0,066 & 4,9 & 1,2 & 0,61 & 0,63 & 0,64 \\
\hline 23 & 11,8 & 0,35 & 0,012 & 0,059 & 5,5 & 1,3 & 0,55 & 0,54 & 0,55 \\
\hline 24 & 12,7 & 0,31 & 0,010 & 0,052 & 6,1 & 1,4 & 0,48 & 0,46 & 0,47 \\
\hline 25 & 13,6 & 0,25 & 0,008 & 0,041 & 6,6 & 1,5 & 0,38 & 0,38 & 0,40 \\
\hline 26 & 14,5 & 0,21 & 0,007 & 0,035 & 7,0 & 1,6 & 0,32 & 0,31 & 0,33 \\
\hline 27 & 15,4 & 0,18 & 0,006 & 0,031 & 7,4 & 1,7 & 0,29 & 0,25 & 0,27 \\
\hline 28 & 16,3 & 0,15 & 0,005 & 0,025 & 7,7 & 1,8 & 0,23 & 0,20 & 0,22 \\
\hline 29 & 17,2 & 0,12 & 0,004 & 0,021 & 8,0 & 1,9 & 0,19 & 0,16 & 0,17 \\
\hline 30 & 18,1 & 0,10 & 0,003 & 0,017 & 9,0 & 2,0 & 0,16 & 0,13 & 0,14 \\
\hline 31 & 22,7 & 0,03 & 0,001 & 0,006 & 9,5 & 2,4 & 0,05 & 0,03 & 0,04 \\
\hline 32 & 27,2 & 0,01 & 0,000 & 0,002 & 9,7 & 2,9 & 0,02 & 0,01 & 0,01 \\
\hline 33 & 31,7 & 0,01 & 0,000 & 0,001 & 9,8 & 3,4 & 0,01 & 0,00 & 0,00 \\
\hline 34 & 36,3 & 0,00 & 0,000 & 0,001 & 9,9 & 3,9 & 0,00 & 0,00 & 0,00 \\
\hline 35 & 40,8 & 0,00 & 0,000 & 0,000 & 9,9 & 4,4 & 0,00 & 0,00 & 0,00 \\
\hline 36 & 45,3 & 0,00 & 0,000 & 0,000 & $+10,0$ & 4,9 & 0,00 & 0,00 & 0,00 \\
\hline 37 & 49,9 & 0,00 & 0,000 & 0,000 & $=\mathrm{I1}$ & 5,4 & 0,00 & 0,00 & 0,00 \\
\hline
\end{tabular}


Ensaio 2 data: 6/dez/2005

Tabela D2.1 - Medidas de vazão para Ensaio 2

\begin{tabular}{|c|c|c|}
\hline $\begin{array}{c}\text { teste de } \\
\text { proveta }\end{array}$ & $\begin{array}{c}\text { tempo } \\
(\mathrm{min})\end{array}$ & $\begin{array}{c}\text { vazão } \\
(\mathrm{L} / \mathrm{h})\end{array}$ \\
\hline 1 & 0 & 68,6 \\
\hline 2 & 0 & 69,2 \\
\hline 3 & 0 & 70,3 \\
\hline 4 & 0 & 68,7 \\
\hline 5 & 2 & 69,6 \\
\hline 6 & 5 & 69,5 \\
\hline 7 & 9 & 68,8 \\
\hline 8 & 12 & 69,8 \\
\hline 9 & 18 & 69,2 \\
\hline 10 & 29 & 69,6 \\
\hline 11 & 40 & 69,2 \\
\hline 12 & 52 & 68,7 \\
\hline 13 & & \\
\hline 14 & & \\
\hline valor médio & 69,3 \\
\hline desvio padrão & 0,5 \\
\hline
\end{tabular}

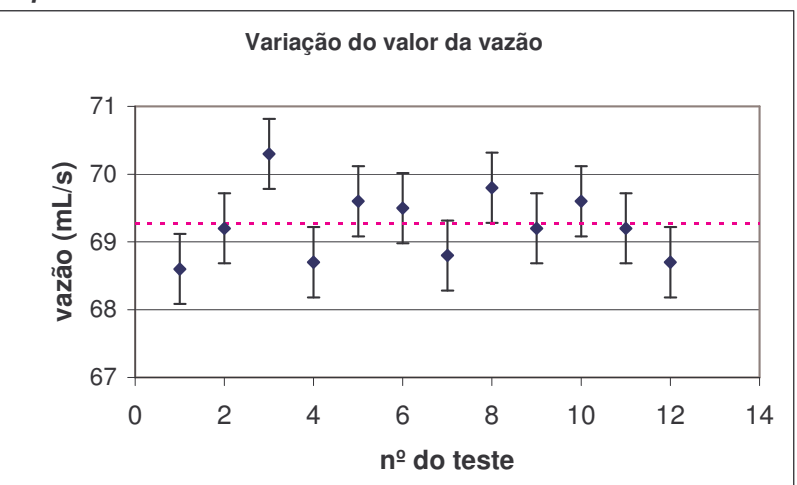

Informações Adicionais:

$\mathrm{V}(\mathrm{L}) \quad 13,8 \quad \pm 0,03 \quad$ (Volume do reator considerando altura do vertedor)

$\tau$ (min) $\quad 11,9 \pm 0,09 \quad$ (Tempo médio de residência $=\mathrm{V} / \mathrm{Q}$ )

$\bar{t}(\min ) \quad 11,8 \quad \pm 0,9 \quad$ (Média da distribuição de tempos de residência)

$\mathrm{V}_{\mathrm{a}}(\mathrm{L}) \quad 13,6 \quad \pm 1,0 \quad$ (Volume de zona ativa)

$\mathrm{V}_{\mathrm{d}}(\mathrm{L}) \quad 0,2 \quad \pm 1,0 \quad$ (Volume de zona morta)

Mc (mg) $131 \quad$ (Massa de traçador injetado no sistema)

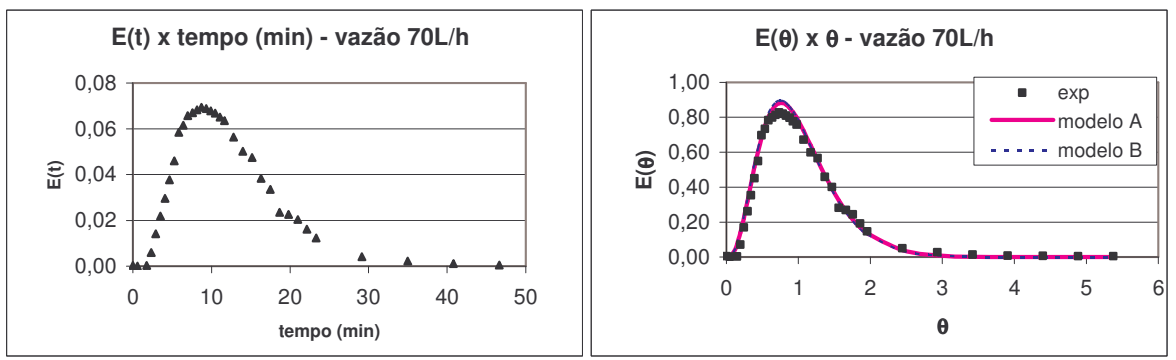

Tabela D2.2 - Dados experimentais obtidos no Ensaio 2 e modelos para ajuste dos dados

\begin{tabular}{|c|c|c|c|c|c|c|c|c|c|}
\hline amostra & $t(\min )$ & $\begin{array}{c}\text { valor ABS } \\
(665 \mathrm{~nm})\end{array}$ & $C(A B S)^{a}$ & $E(t){ }^{b}$ & $t(\min )^{c}$ & $\theta=\mathrm{t} / \tau$ & $E(\theta)=\tau^{\star} E(t)$ & $\begin{array}{c}\mathrm{E}(\theta) \\
\text { modelo } \mathrm{A}\end{array}$ & $\begin{array}{c}\mathrm{E}(\theta) \\
\text { modelo B }\end{array}$ \\
\hline 0 & 0,0 & 0,00 & 0,000 & 0,000 & 0,0 & 0,0 & 0,00 & 0,00 & 0,00 \\
\hline 1 & 0,6 & 0,00 & 0,000 & 0,000 & 0,0 & 0,0 & 0,00 & 0,00 & 0,00 \\
\hline 2 & 1,2 & 0,00 & 0,000 & 0,000 & 0,0 & 0,1 & 0,00 & 0,03 & 0,03 \\
\hline 3 & 1,8 & 0,00 & 0,000 & 0,000 & 0,0 & 0,1 & 0,00 & 0,07 & 0,07 \\
\hline 4 & 2,3 & 0,05 & 0,002 & 0,006 & 0,0 & 0,2 & 0,07 & 0,14 & 0,15 \\
\hline 5 & 2.9 & 0,11 & 0,004 & 0,014 & 0,1 & 0,2 & 0,17 & 0,22 & 0,23 \\
\hline 6 & 3,5 & 0,24 & 0,008 & 0,022 & 0,1 & 0,3 & 0,26 & 0,32 & 0,33 \\
\hline 7 & 4,1 & 0,23 & 0,008 & 0,030 & 0,2 & 0,3 & 0,35 & 0,42 & 0,43 \\
\hline 8 & 4,7 & 0,37 & 0,012 & 0,038 & 0,3 & 0,4 & 0,45 & 0,51 & 0,53 \\
\hline 9 & 5,3 & 0,36 & 0,012 & 0,046 & 0,5 & 0,4 & 0,55 & 0,60 & 0,63 \\
\hline 10 & 5,8 & 0,46 & 0,015 & 0,058 & 0,7 & 0,5 & 0,70 & 0,68 & 0,71 \\
\hline 11 & 6,4 & 0,49 & 0,016 & 0,062 & 1,0 & 0,5 & 0,73 & 0,75 & 0,77 \\
\hline 12 & 7,0 & 0,52 & 0,017 & 0,066 & 1,2 & 0,6 & 0,78 & 0,80 & 0,82 \\
\hline 13 & 7,6 & 0,55 & 0,018 & 0,067 & 1,5 & 0,6 & 0,80 & 0,84 & 0,86 \\
\hline 14 & 8,2 & 0,55 & 0,018 & 0,068 & 1,9 & 0,7 & 0,81 & 0,87 & 0,89 \\
\hline 15 & 8,7 & 0,56 & 0,018 & 0,069 & 2,3 & 0,7 & 0,83 & 0,88 & 0,90 \\
\hline 16 & 9,3 & 0,56 & 0,018 & 0,069 & 2,6 & 0,8 & 0,82 & 0,88 & 0,89 \\
\hline 17 & 9,9 & 0,56 & 0,018 & 0,068 & 3,0 & 0,8 & 0,81 & 0,87 & 0,88 \\
\hline 18 & 10,5 & 0,56 & 0,018 & 0,067 & 3,4 & 0,9 & 0,80 & 0,85 & 0,86 \\
\hline 19 & 11,1 & 0,55 & 0,018 & 0,065 & 3,9 & 0,9 & 0,78 & 0,83 & 0,83 \\
\hline 20 & 11,7 & 0,53 & 0,017 & 0,064 & 4,7 & 1,0 & 0,76 & 0,80 & 0,80 \\
\hline 21 & 12,8 & 0,47 & 0,016 & 0,056 & 5,6 & 1,1 & 0,67 & 0,72 & 0,72 \\
\hline 22 & 14,0 & 0,42 & 0,014 & 0,050 & 6,4 & 1,2 & 0,60 & 0,64 & 0,63 \\
\hline 23 & 15,2 & 0,40 & 0,013 & 0,047 & 7,2 & 1,3 & 0,57 & 0,55 & 0,54 \\
\hline 24 & 16,3 & 0,33 & 0,011 & 0,038 & 7,9 & 1,4 & 0,46 & 0,47 & 0,46 \\
\hline 25 & 17,5 & 0,29 & 0,010 & 0,034 & 8,5 & 1,5 & 0,40 & 0,39 & 0,38 \\
\hline 26 & 18,7 & 0,21 & 0,007 & 0,024 & 9,0 & 1,6 & 0,28 & 0,32 & 0,31 \\
\hline 27 & 19,8 & 0,21 & 0,007 & 0,023 & 9,5 & 1,7 & 0,27 & 0,26 & 0,25 \\
\hline 28 & 21,0 & 0,19 & 0,006 & 0,020 & 10,0 & 1,8 & 0,24 & 0,21 & 0,20 \\
\hline 29 & 22,2 & 0,16 & 0,005 & 0,016 & 10,3 & 1,9 & 0,19 & 0,17 & 0,16 \\
\hline 30 & 23,3 & 0,12 & 0,004 & 0,012 & 11,5 & 2,0 & 0,15 & 0,14 & 0,13 \\
\hline 31 & 29,1 & 0,06 & 0,002 & 0,004 & 12,1 & 2,4 & 0,05 & 0,04 & 0,04 \\
\hline 32 & 35,0 & 0,05 & 0,001 & 0,002 & 12,5 & 2,9 & 0,03 & 0,01 & 0,01 \\
\hline 33 & 40,8 & 0,04 & 0,001 & 0,001 & 12,7 & 3,4 & 0,01 & 0,00 & 0,00 \\
\hline 34 & 46,6 & 0,03 & 0,001 & 0,001 & 12,9 & 3,9 & 0,01 & 0,00 & 0,00 \\
\hline 35 & 52,5 & 0,03 & 0,001 & 0,001 & 13,0 & 4,4 & 0,01 & 0,00 & 0,00 \\
\hline 36 & 58,3 & 0,03 & 0,001 & 0,000 & 13,1 & 4,9 & 0,00 & 0,00 & 0,00 \\
\hline 37 & 64,1 & 0,03 & 0,001 & 0,000 & = I1 & 5,4 & 0,00 & 0,00 & 0,00 \\
\hline
\end{tabular}


Ensaio $3 \quad$ data: 6/dez/2005

Tabela D.1 - Medidas de vazão para Ensaio 3

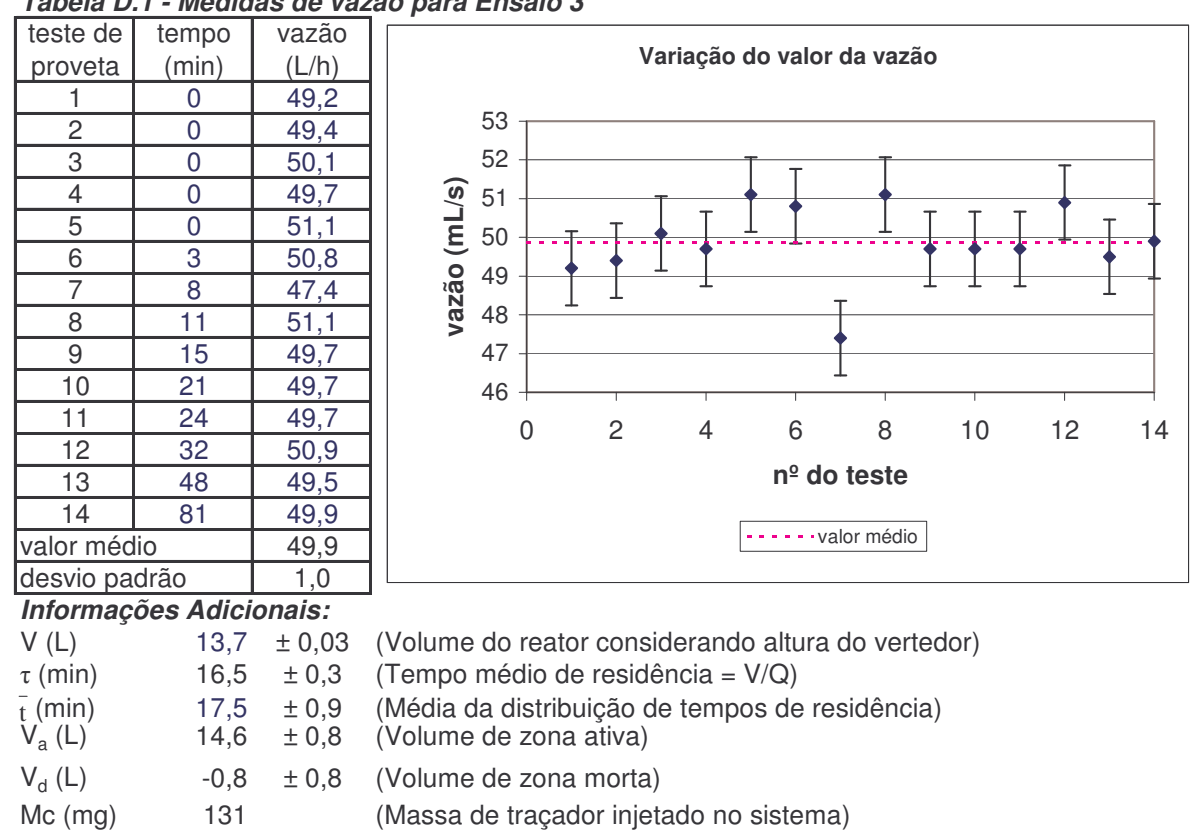

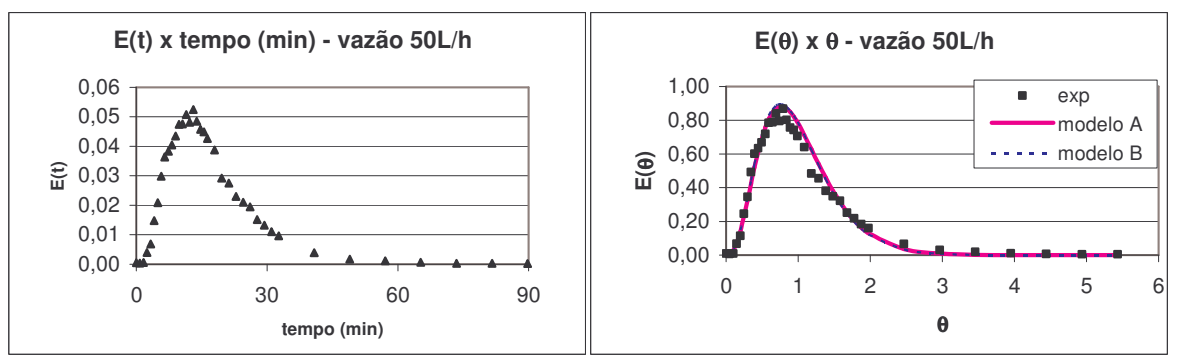

Tabela D.2 - Dados experimentais obtidos no Ensaio 3 e modelos para ajuste dos dados

\begin{tabular}{|c|c|c|c|c|c|c|c|c|c|}
\hline amostra & $t(\min )$ & $\begin{array}{c}\text { valor ABS } \\
(665 \mathrm{~nm})\end{array}$ & $C(A B S)^{a}$ & $E(t) b$ & $\mathrm{t}(\min )^{c}$ & $\theta=t / \tau$ & $E(\theta)=\tau^{\star} E(t)$ & $\begin{array}{c}\mathrm{E}(\theta) \\
\text { modelo } \mathrm{A}\end{array}$ & $\begin{array}{c}\mathrm{E}(\theta) \\
\text { modelo B }\end{array}$ \\
\hline 0 & 0,0 & 0,01 & 0,000 & 0,001 & 0,0 & 0,0 & 0,01 & 0,00 & 0,00 \\
\hline 1 & 0,8 & 0,00 & 0,000 & 0,000 & 0,0 & 0,0 & 0,01 & 0,00 & 0,00 \\
\hline 2 & 1,6 & 0,01 & 0,000 & 0,001 & 0,0 & 0,1 & 0,01 & 0,03 & 0,03 \\
\hline 3 & 2,5 & 0,04 & 0,001 & 0,004 & 0,0 & 0,1 & 0,07 & 0,07 & 0,08 \\
\hline 4 & 3,3 & 0,06 & 0,002 & 0,007 & 0,1 & 0,2 & 0,11 & 0,14 & 0,15 \\
\hline 5 & 4,1 & 0,14 & 0,005 & 0,015 & 0,1 & 0,2 & 0,25 & 0,23 & 0,24 \\
\hline 6 & 4,9 & 0,20 & 0,006 & 0,021 & 0,2 & 0,3 & 0,35 & 0,32 & 0,34 \\
\hline 7 & 5,7 & 0,28 & 0,009 & 0,030 & 0,4 & 0,3 & 0,49 & 0,42 & 0,44 \\
\hline 8 & 6,5 & 0,34 & 0,011 & 0,036 & 0,6 & 0,4 & 0,60 & 0,52 & 0,54 \\
\hline 9 & 7,3 & 0,44 & 0,015 & 0,038 & 0,9 & 0,4 & 0,63 & 0,61 & 0,63 \\
\hline 10 & 8,2 & 0,38 & 0,012 & 0,040 & 1,2 & 0,5 & 0,67 & 0,69 & 0,71 \\
\hline 11 & 9,0 & 0,41 & 0,013 & 0,043 & 1,5 & 0,5 & 0,72 & 0,76 & 0,78 \\
\hline 12 & 9,8 & 0,44 & 0,015 & 0,047 & 1,9 & 0,6 & 0,78 & 0,81 & 0,83 \\
\hline 13 & 10,6 & 0,45 & 0,015 & 0,048 & 2,3 & 0,6 & 0,79 & 0,85 & 0,87 \\
\hline 14 & 11,4 & 0,48 & 0,016 & 0,051 & 2,8 & 0,7 & 0,84 & 0,87 & 0,89 \\
\hline 15 & 12,2 & 0,45 & 0,015 & 0,048 & 3,3 & 0,7 & 0,80 & 0,88 & 0,90 \\
\hline 16 & 13,1 & 0,49 & 0,016 & 0,052 & 3,9 & 0,8 & 0,87 & 0,88 & 0,89 \\
\hline 17 & 13,9 & 0,45 & 0,015 & 0,049 & 4,4 & 0,8 & 0,80 & 0,87 & 0,88 \\
\hline 18 & 14,7 & 0,43 & 0,014 & 0,046 & 5,0 & 0,9 & 0,76 & 0,85 & 0,86 \\
\hline 19 & 15,5 & 0,42 & 0,014 & 0,045 & 5,6 & 0,9 & 0,74 & 0,82 & 0,83 \\
\hline 20 & 16,3 & 0,40 & 0,013 & 0,043 & 6,7 & 1,0 & 0,71 & 0,79 & 0,79 \\
\hline 21 & 18,0 & 0,36 & 0,012 & 0,039 & 7,7 & 1,1 & 0,64 & 0,71 & 0,71 \\
\hline 22 & 19,6 & 0,27 & 0,009 & 0,029 & 8,7 & 1,2 & 0,48 & 0,63 & 0,62 \\
\hline 23 & 21,2 & 0,26 & 0,008 & 0,028 & 9,6 & 1,3 & 0,46 & 0,54 & 0,53 \\
\hline 24 & 22,9 & 0,22 & 0,007 & 0,023 & 10,4 & 1,4 & 0,38 & 0,46 & 0,45 \\
\hline 25 & 24,5 & 0,20 & 0,006 & 0,021 & 11,3 & 1,5 & 0,35 & 0,38 & 0,37 \\
\hline 26 & 26,1 & 0,18 & 0,006 & 0,019 & 12,0 & 1,6 & 0,32 & 0,31 & 0,30 \\
\hline 27 & 27,7 & 0,14 & 0,005 & 0,015 & 12,7 & 1,7 & 0,25 & 0,26 & 0,25 \\
\hline 28 & 29,4 & 0,12 & 0,004 & 0,013 & 13,3 & 1,8 & 0,22 & 0,21 & 0,20 \\
\hline 29 & 31,0 & 0,10 & 0,003 & 0,011 & 13,8 & 1,9 & 0,18 & 0,16 & 0,16 \\
\hline 30 & 32,6 & 0,09 & 0,003 & 0,010 & 15,8 & 2,0 & 0,16 & 0,13 & 0,12 \\
\hline 31 & 40,8 & 0,04 & 0,001 & 0,004 & 16,8 & 2,5 & 0,07 & 0,04 & 0,03 \\
\hline 32 & 49,0 & 0,02 & 0,001 & 0,002 & 17,4 & 3,0 & 0,03 & 0,01 & 0,01 \\
\hline 33 & 57,1 & 0,01 & 0,000 & 0,001 & 17,9 & 3,5 & 0,02 & 0,00 & 0,00 \\
\hline 34 & 65,3 & 0,01 & 0,000 & 0,001 & 18,2 & 3,9 & 0,01 & 0,00 & 0,00 \\
\hline 35 & 73,4 & 0,00 & 0,000 & 0,000 & 18,4 & 4,4 & 0,01 & 0,00 & 0,00 \\
\hline 36 & 81,6 & 0,00 & 0,000 & 0,000 & $+18,6$ & 4,9 & 0,01 & 0,00 & 0,00 \\
\hline 37 & 89,8 & 0,00 & 0,000 & 0,000 & $=\mathrm{I1}$ & 5,4 & 0,00 & 0,00 & 0,00 \\
\hline
\end{tabular}


Ensaio 4 data: 6/dez/2005

Tabela D4.1 - Medidas de vazão para Ensaio 4

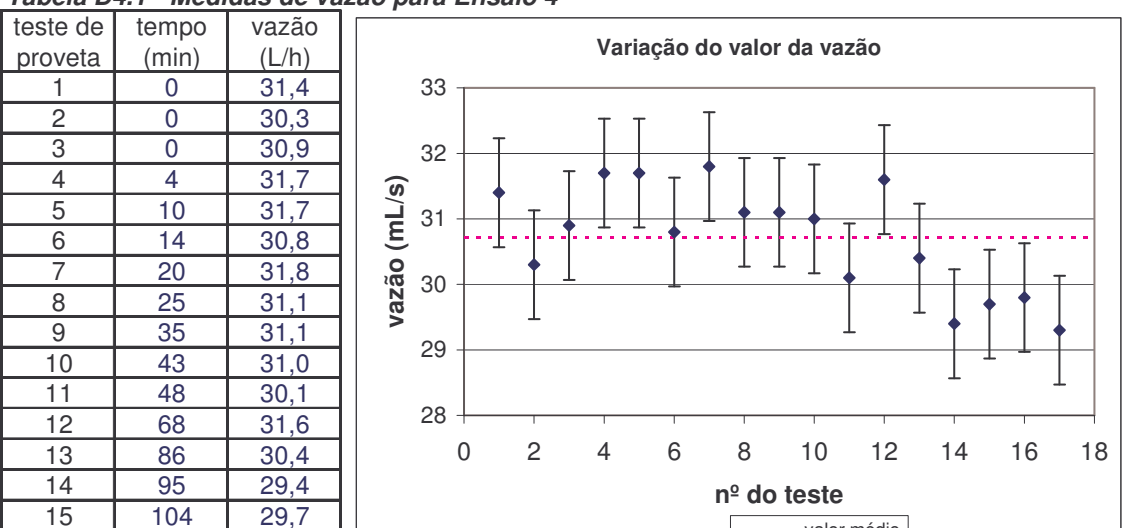

\begin{tabular}{|c|c|c|}
\hline 15 & 104 & 29,7 \\
\hline 16 & 116 & 29,8 \\
\hline 17 & 131 & 29,3 \\
\hline valor médio & 30,7 \\
\hline desvio padrão & 0,8 \\
\hline
\end{tabular}

-.... valor médio

\section{Informaçôes Adicionais:}

$\mathrm{V}$ (L) $\quad 13,7 \quad \pm 0,03 \quad$ (Volume do reator considerando altura do vertedor)

$\tau(\min ) \quad 26,8 \quad \pm 0,7 \quad$ (Tempo médio de residência $=\mathrm{V} / \mathrm{Q}$ )

$\mathrm{t}$ (min) 25,5 $\pm 0,9 \quad$ (Média da distribuição de tempos de residência)

$V_{a}(L) \quad 13,1 \quad \pm 0,6 \quad$ (Volume de zona ativa)

$\mathrm{V}_{\mathrm{d}}(\mathrm{L}) \quad 0,7 \quad \pm 0,6 \quad$ (Volume de zona morta)

Mc (mg) 130,9 (Massa de traçador injetado no sistema)

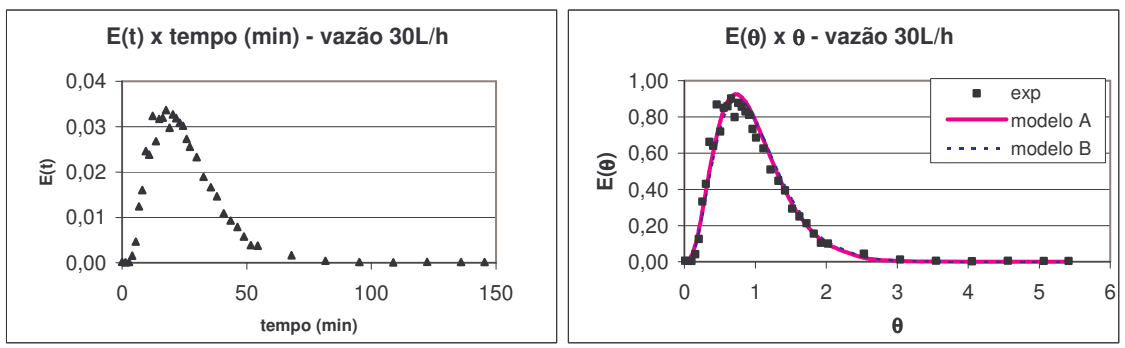

Tabela D4.2 - Dados experimentais obtidos no Ensaio 4 e modelos para ajuste dos dados

\begin{tabular}{|c|c|c|c|c|c|c|c|c|c|}
\hline amostra & $t(\min )$ & $\begin{array}{c}\text { valor ABS } \\
(665 \mathrm{~nm})\end{array}$ & $C(A B S)^{a}$ & $E(t)^{b}$ & $\bar{t}(\min )^{c}$ & $\theta=t / \tau$ & $E(\theta)=\tau^{*} E(t)$ & $\begin{array}{c}\mathrm{E}(\theta) \\
\text { modelo } \mathrm{A}\end{array}$ & $\begin{array}{c}\mathrm{E}(\theta) \\
\text { modelo B }\end{array}$ \\
\hline 0 & 0,0 & 0,00 & 0,000 & 0,000 & 0,0 & 0,0 & 0,01 & 0,00 & 0,00 \\
\hline 1 & 1,4 & 0,00 & 0,000 & 0,000 & 0,0 & 0,1 & 0,00 & 0,01 & 0,00 \\
\hline 2 & 2,7 & 0,00 & 0,000 & 0,000 & 0,0 & 0,1 & 0,00 & 0,03 & 0,03 \\
\hline 3 & 4,1 & 0,02 & 0,001 & 0,002 & 0,0 & 0,2 & 0,04 & 0,09 & 0,08 \\
\hline 4 & 5,4 & 0,06 & 0,002 & 0,005 & 0,1 & 0,2 & 0,13 & 0,17 & 0,16 \\
\hline 5 & 6,8 & 0,17 & 0,006 & 0,012 & 0,2 & 0,3 & 0,33 & 0,28 & 0,25 \\
\hline 6 & 8,2 & 0,22 & 0,007 & 0,016 & 0,5 & 0,3 & 0,43 & 0,39 & 0,36 \\
\hline 7 & 9,5 & 0,34 & 0,011 & 0,025 & 0,8 & 0,4 & 0,66 & 0,50 & 0,46 \\
\hline 8 & 10,9 & 0,33 & 0,011 & 0,024 & 1,3 & 0,4 & 0,64 & 0,61 & 0,56 \\
\hline 9 & 12,2 & 0,44 & 0,015 & 0,032 & 1,8 & 0,5 & 0,87 & 0,70 & 0,65 \\
\hline 10 & 13,6 & 0,37 & 0,012 & 0,027 & 2,4 & 0,5 & 0,72 & 0,78 & 0,73 \\
\hline 11 & 15,0 & 0,43 & 0,014 & 0,032 & 3,0 & 0,6 & 0,85 & 0,84 & 0,79 \\
\hline 12 & 16,3 & 0,44 & 0,014 & 0,032 & 3,8 & 0,6 & 0,86 & 0,88 & 0,84 \\
\hline 13 & 17,7 & 0,46 & 0,015 & 0,034 & 4,6 & 0,7 & 0,90 & 0,91 & 0,87 \\
\hline 14 & 19,0 & 0,41 & 0,013 & 0,030 & 5,4 & 0,7 & 0,80 & 0,92 & 0,89 \\
\hline 15 & 20,4 & 0,45 & 0,015 & 0,033 & 6,4 & 0,8 & 0,88 & 0,92 & 0,90 \\
\hline 16 & 21,8 & 0,44 & 0,014 & 0,032 & 7,3 & 0,8 & 0,86 & 0,91 & 0,89 \\
\hline 17 & 23,1 & 0,42 & 0,014 & 0,031 & 8,3 & 0,9 & 0,83 & 0,88 & 0,87 \\
\hline 18 & 24,5 & 0,41 & 0,014 & 0,030 & 9,3 & 0,9 & 0,81 & 0,85 & 0,84 \\
\hline 19 & 25,8 & 0,37 & 0,012 & 0,027 & 10,2 & 1,0 & 0,73 & 0,81 & 0,81 \\
\hline 20 & 27,2 & 0,35 & 0,012 & 0,026 & 12,1 & 1,0 & 0,69 & 0,77 & 0,77 \\
\hline 21 & 29,9 & 0,32 & 0,010 & 0,023 & 13,9 & 1,1 & 0,63 & 0,67 & 0,68 \\
\hline 22 & 32,6 & 0,26 & 0,009 & 0,019 & 15,7 & 1,2 & 0,51 & 0,57 & 0,59 \\
\hline 23 & 35,6 & 0,23 & 0,008 & 0,017 & 17,1 & 1,3 & 0,45 & 0,47 & 0,49 \\
\hline 24 & 38,1 & 0,20 & 0,007 & 0,015 & 18,5 & 1,4 & 0,39 & 0,40 & 0,42 \\
\hline 25 & 40,8 & 0,15 & 0,005 & 0,011 & 19,7 & 1,5 & 0,29 & 0,32 & 0,34 \\
\hline 26 & 43,5 & 0,13 & 0,004 & 0,009 & 20,7 & 1,6 & 0,25 & 0,26 & 0,28 \\
\hline 27 & 46,2 & 0,11 & 0,004 & 0,008 & 21,6 & 1,7 & 0,21 & 0,20 & 0,22 \\
\hline 28 & 49,0 & 0,08 & 0,003 & 0,006 & 22,3 & 1,8 & 0,15 & 0,16 & 0,18 \\
\hline 29 & 51,7 & 0,05 & 0,002 & 0,004 & 22,8 & 1,9 & 0,10 & 0,12 & 0,14 \\
\hline 30 & 54,4 & 0,05 & 0,002 & 0,004 & 25,0 & 2,0 & 0,10 & 0,09 & 0,11 \\
\hline 31 & 68,0 & 0,02 & 0,001 & 0,002 & 26,0 & 2,5 & 0,04 & 0,02 & 0,03 \\
\hline 32 & 81,6 & 0,01 & 0,000 & 0,000 & 26,4 & 3,0 & 0,01 & 0,00 & 0,01 \\
\hline 33 & 95,2 & 0,00 & 0,000 & 0,000 & 26,6 & 3,5 & 0,00 & 0,00 & 0,00 \\
\hline 34 & 108,8 & 0,00 & 0,000 & 0,000 & 26,8 & 4,1 & 0,00 & 0,00 & 0,00 \\
\hline 35 & 122,4 & 0,00 & 0,000 & 0,000 & 27,2 & 4,6 & 0,01 & 0,00 & 0,00 \\
\hline 36 & 136,0 & 0,00 & 0,000 & 0,000 & 27,4 & 5,1 & 0,00 & 0,00 & 0,00 \\
\hline 37 & 145,4 & 0,01 & 0,000 & 0,000 & $=\mathrm{I1}$ & 5,4 & 0,00 & 0,00 & 0,00 \\
\hline
\end{tabular}


Ensaio 5 data: 7/dez/2005

Tabela D5.1 - Medidas de vazão para Ensaio 5

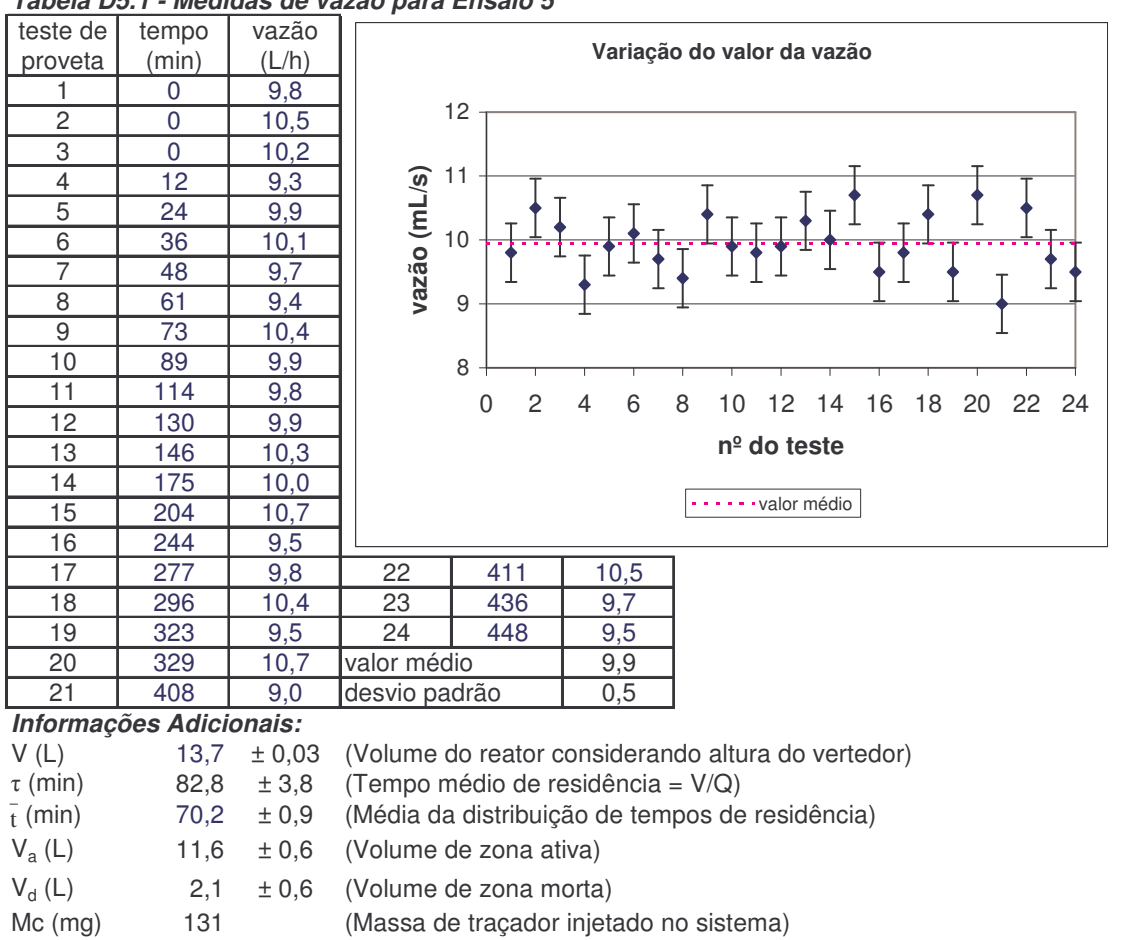

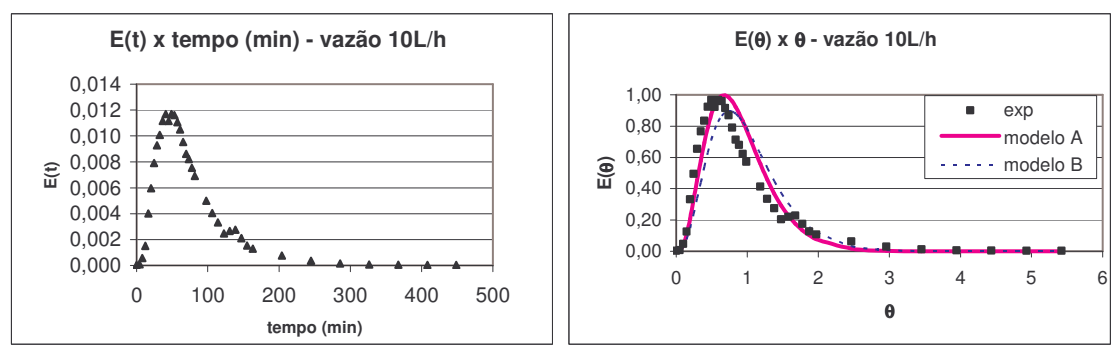

Tabela D5.2 - Dados experimentais obtidos no Ensaio 5 e modelos para ajuste dos dados

\begin{tabular}{|c|c|c|c|c|c|c|c|c|c|}
\hline amostra & $t(\min )$ & $\begin{array}{c}\text { valor ABS } \\
(665 \mathrm{~nm})\end{array}$ & $C(A B S)^{a}$ & $E(t)^{b}$ & $\bar{t}(\min )^{c}$ & $\theta=\mathrm{t} / \tau$ & $E(\theta)=\tau^{*} E(t)$ & $\begin{array}{c}E(\theta) \\
\text { modelo } A\end{array}$ & $\begin{array}{c}\mathrm{E}(\theta) \\
\text { modelo } \mathrm{B}\end{array}$ \\
\hline 0 & 0,0 & 0,00 & 0,000 & 0,000 & 0,0 & 0,0 & 0,00 & 0,00 & 0,00 \\
\hline 1 & 4,1 & 0,01 & 0,000 & 0,000 & 0,0 & 0,0 & 0,01 & 0,01 & 0,00 \\
\hline 2 & 8,2 & 0,05 & 0,002 & 0,001 & 0,1 & 0,1 & 0,05 & 0,04 & 0,03 \\
\hline 3 & 12,2 & 0,13 & 0,004 & 0,002 & 0,2 & 0,1 & 0,13 & 0,11 & 0,08 \\
\hline 4 & 16,3 & 0,35 & 0,011 & 0,004 & 0,6 & 0,2 & 0,33 & 0,21 & 0,15 \\
\hline 5 & 20,4 & 0,52 & 0,017 & 0,006 & 1,3 & 0,2 & 0,49 & 0,33 & 0,24 \\
\hline 6 & 24,5 & 0,69 & 0,023 & 0,008 & 2,2 & 0,3 & 0,66 & 0,45 & 0,34 \\
\hline 7 & 28,6 & 0,81 & 0,027 & 0,009 & 3,4 & 0,3 & 0,77 & 0,58 & 0,44 \\
\hline 8 & 32,6 & 0,88 & 0,029 & 0,010 & 4,9 & 0,4 & 0,83 & 0,69 & 0,54 \\
\hline 9 & 36,7 & 0,97 & 0,032 & 0,011 & 6,7 & 0,4 & 0,92 & 0,79 & 0,63 \\
\hline 10 & 40,8 & 1,02 & 0,033 & 0,012 & 8,7 & 0,5 & 0,97 & 0,87 & 0,71 \\
\hline 11 & 44,9 & 0,97 & 0,032 & 0,011 & 10,9 & 0,5 & 0,92 & 0,93 & 0,78 \\
\hline 12 & 49,0 & 1,02 & 0,033 & 0,012 & 13,3 & 0,6 & 0,97 & 0,97 & 0,83 \\
\hline 13 & 53,0 & 1,01 & 0,033 & 0,012 & 15,9 & 0,6 & 0,96 & 0,99 & 0,87 \\
\hline 14 & 57,1 & 0,97 & 0,032 & 0,011 & 18,5 & 0,7 & 0,92 & 1,00 & 0,89 \\
\hline 15 & 61,2 & 0,92 & 0,030 & 0,011 & 21,1 & 0,7 & 0,87 & 0,98 & 0,90 \\
\hline 16 & 65,3 & 0,83 & 0,027 & 0,010 & 23,5 & 0,8 & 0,79 & 0,96 & 0,89 \\
\hline 17 & 69,4 & 0,75 & 0,025 & 0,009 & 26,0 & 0,8 & 0,71 & 0,92 & 0,88 \\
\hline 18 & 73,4 & 0,72 & 0,023 & 0,008 & 28,4 & 0,9 & 0,68 & 0,88 & 0,86 \\
\hline 19 & 77,5 & 0,66 & 0,022 & 0,008 & 30,8 & 0,9 & 0,62 & 0,83 & 0,83 \\
\hline 20 & 81,6 & 0,60 & 0,020 & 0,007 & 39,4 & 1,0 & 0,57 & 0,78 & 0,79 \\
\hline 22 & 97,9 & 0,44 & 0,014 & 0,005 & 43,1 & 1,2 & 0,41 & 0,56 & 0,62 \\
\hline 23 & 106,1 & 0,35 & 0,012 & 0,004 & 46,4 & 1,3 & 0,33 & 0,46 & 0,53 \\
\hline 24 & 114,2 & 0,29 & 0,010 & 0,003 & 49,2 & 1,4 & 0,28 & 0,37 & 0,45 \\
\hline 25 & 122,4 & 0,22 & 0,007 & 0,002 & 51,9 & 1,5 & 0,21 & 0,29 & 0,37 \\
\hline 26 & 130,6 & 0,23 & 0,008 & 0,003 & 54,8 & 1,6 & 0,22 & 0,23 & 0,30 \\
\hline 27 & 138,7 & 0,24 & 0,008 & 0,003 & 57,7 & 1,7 & 0,23 & 0,18 & 0,25 \\
\hline 28 & 146,9 & 0,18 & 0,006 & 0,002 & 59,9 & 1,8 & 0,17 & 0,14 & 0,20 \\
\hline 29 & 155,0 & 0,13 & 0,004 & 0,002 & 61,7 & 1,9 & 0,13 & 0,10 & 0,16 \\
\hline 30 & 163,2 & 0,11 & 0,004 & 0,001 & 69,3 & 2,0 & 0,11 & 0,08 & 0,12 \\
\hline 31 & 204,0 & 0,07 & 0,002 & 0,001 & 74,3 & 2,5 & 0,06 & 0,02 & 0,03 \\
\hline 32 & 244,8 & 0,03 & 0,001 & 0,000 & 77,0 & 3,0 & 0,03 & 0,00 & 0,01 \\
\hline 33 & 285,6 & 0,01 & 0,000 & 0,000 & 78,4 & 3,5 & 0,01 & 0,00 & 0,00 \\
\hline 34 & 326,4 & 0,01 & 0,000 & 0,000 & 79,4 & 3,9 & 0,01 & 0,00 & 0,00 \\
\hline 35 & 367,2 & 0,01 & 0,000 & 0,000 & 80,3 & 4,4 & 0,01 & 0,00 & 0,00 \\
\hline 36 & 408,0 & 0,00 & 0,000 & 0,000 & 80,9 & 4,9 & 0,00 & 0,00 & 0,00 \\
\hline 37 & 448,8 & 0,00 & 0,000 & 0,000 & $=$ I1 & 5,4 & 0,00 & 0,00 & 0,00 \\
\hline
\end{tabular}


APÊNDICE E - Resultados dos ensaios fotoquímicos contínuos

\begin{tabular}{|c|c|c|c|c|c|c|c|c|c|c|}
\hline & \multicolumn{3}{|c|}{ 8/dez/2005 } & \multirow{2}{*}{\multicolumn{2}{|c|}{\begin{tabular}{|l|} 
Série \\
Ensaio №
\end{tabular}}} & \multicolumn{4}{|c|}{ Plano Dohlert 2} \\
\hline & & \multicolumn{3}{|c|}{ Contínuo } & & & \multicolumn{4}{|c|}{1} \\
\hline \multicolumn{2}{|c|}{ Efluente } & & \multicolumn{2}{|c|}{ D806 } & \multirow{2}{*}{\multicolumn{2}{|c|}{$\frac{\text { TOC }_{0} \text { inicial }}{50 \mathrm{~L} / \mathrm{h}}$}} & \multicolumn{4}{|c|}{$6,70 \mathrm{ppmC}$} \\
\hline \multicolumn{5}{|c|}{ Vazão do efluente } & & & \multicolumn{4}{|c|}{ (vazão de tratamento) } \\
\hline \multicolumn{5}{|c|}{ Volume de efluente } & \multicolumn{2}{|c|}{$50 \mathrm{~L} / \mathrm{h}$} & \multicolumn{4}{|c|}{ (sistema tanque + reator) } \\
\hline \multicolumn{5}{|c|}{ Volume reator (incluindo vertedor) } & \multicolumn{6}{|c|}{ (t) } \\
\hline \multicolumn{3}{|c|}{ Tempo de reação } & \multicolumn{2}{|c|}{$50 \mathrm{~min}$} & \multicolumn{2}{|c|}{ Tempo de res } & ência $(\tau)$ & & \multicolumn{2}{|c|}{$16 \mathrm{~min}$} \\
\hline \multirow{2}{*}{\multicolumn{5}{|c|}{$\begin{array}{ll}\mathrm{H}_{2} \mathrm{O}_{2} & 30,00 \% \\
\end{array}$}} & \multirow{2}{*}{\multicolumn{6}{|c|}{$\begin{array}{c}2 \text { comercial) } \quad \text { densidade } 1,1122 \mathrm{~g} / \mathrm{cm} 3 \\
\text { contínua }\left(1^{\circ} \text { compartimento) }\right.\end{array}$}} \\
\hline & & & & & & & & & & \\
\hline \multirow{2}{*}{\multicolumn{5}{|c|}{ Desvio $\quad 60,81 \%$}} & \multicolumn{6}{|c|}{$1,06 \mathrm{X}$ valor estequiométrico } \\
\hline & & & & & \multicolumn{6}{|c|}{$1,70 \mathrm{X}$ valor estequiométrico (real) } \\
\hline \multicolumn{5}{|c|}{$\begin{array}{l}\text { Volume de } \mathrm{H}_{2} \mathrm{O}_{2} \\
1000 \mathrm{~mL} \mathrm{H}_{2} \mathrm{O} 2 \text { A } 0,99 \%\end{array}$} & \multicolumn{6}{|c|}{$\begin{array}{l}10 \mathrm{~mL} \mathrm{H2O} 2 \text { A } 30,00 \% \text { diluído em } \\
990 \mathrm{~mL} \text { água destilada }\end{array}$} \\
\hline Concen & ração & $\mathrm{H}_{2} \mathrm{O}_{2}$ & & & 2,36 & & ba & se de cé & Iculo: 4 & \\
\hline Tempo C & le adiçấ & & & $50 \mathrm{~min}$ & Vazão c & $\mathrm{e}_{2} \mathrm{O}_{2}$ & & & 0,003 & $\mathrm{~mL} / \mathrm{s}$ \\
\hline$\frac{\text { Fonte de }}{\text { Potência }}$ & luz & $\begin{array}{l}\frac{a r t i f i c i a l}{250 \mathrm{~W}} \\
250\end{array}$ & & & Lâm & pada d & vapor $\mathrm{c}$ & le merc & úrio $(\mathrm{HI}$ & LN) \\
\hline № de lar & & 4 & & & Valor de & $\alpha(\mathrm{mgh}$ & $2 \mathrm{O} 2 / \mathrm{mg}$ & TOC) & & 14 \\
\hline $\begin{array}{l}\text { Observa } \\
\text { entre } 4 \\
\text { volume }\end{array}$ & $\begin{array}{l}\text { tỗes } \\
8 \text { min: } \\
\text { etirado }\end{array}$ & vazão re & $\begin{array}{l}\text { duziu à } \\
\text { na para }\end{array}$ & most & gem (apr & UX). & $\begin{array}{l}\text { nte corrig } \\
452\end{array}$ & & & \\
\hline Tempo & & & $\mathrm{TOC}(\mathrm{m}$ & $\mathrm{g} \mathrm{g} / \mathrm{L})$ & & & Tempera & tura $\left({ }^{\circ} \mathrm{C}\right.$ & & $\mathrm{pH}$ \\
\hline$(\min )$ & $\Theta=t / \tau$ & $1^{\circ} \mathrm{cp}$. & $2^{\circ} \mathrm{cp}$ & & $4^{\circ} \mathrm{cp}$. & $1^{\circ} \mathrm{cp}$. & $2^{\circ} \mathrm{cp}$ & $3^{\circ} \mathrm{cp}$ & $4^{\circ} \mathrm{cp}$. & $4^{\circ} \mathrm{cp}$ \\
\hline 0 & 0,0 & 5,53 & & 5,578 & & & & & & \\
\hline 0 & 0,0 & 5,554 & 5,554 & 5,554 & 5,554 & 23 & & 22 & 23 & 6,09 \\
\hline$\frac{4}{4}$ & 0,2 & 5,397 & $\frac{0,254}{5,256}$ & 5,451 & 6,025 & $\frac{25}{25}$ & $\frac{25}{25}$ & $\frac{25}{25}$ & $\frac{5}{24}$ & $\frac{0,01}{6,01}$ \\
\hline 8 & 0,5 & 4,617 & 4,311 & 4,614 & 4,983 & 26 & 26 & 28 & 28 & 5,86 \\
\hline 17 & 1,0 & 4,468 & 3,671 & 3,095 & 3,079 & 27 & 29 & 31 & 32 & 5,23 \\
\hline 33 & 2,0 & 4,316 & 3,608 & $\frac{3,087}{3,07}$ & $\frac{2,691}{2,691}$ & 27 & 30 & 33 & 35 & $\frac{u, c 5}{5,25}$ \\
\hline 50 & 3,0 & 4,757 & 3,629 & 2,866 & 2,62 & 27 & 30 & 33 & 35 & 5,24 \\
\hline$\Delta \mathrm{COT}$ & & 0,14 & 0,35 & 0,48 & 0,53 & & & & & \\
\hline
\end{tabular}

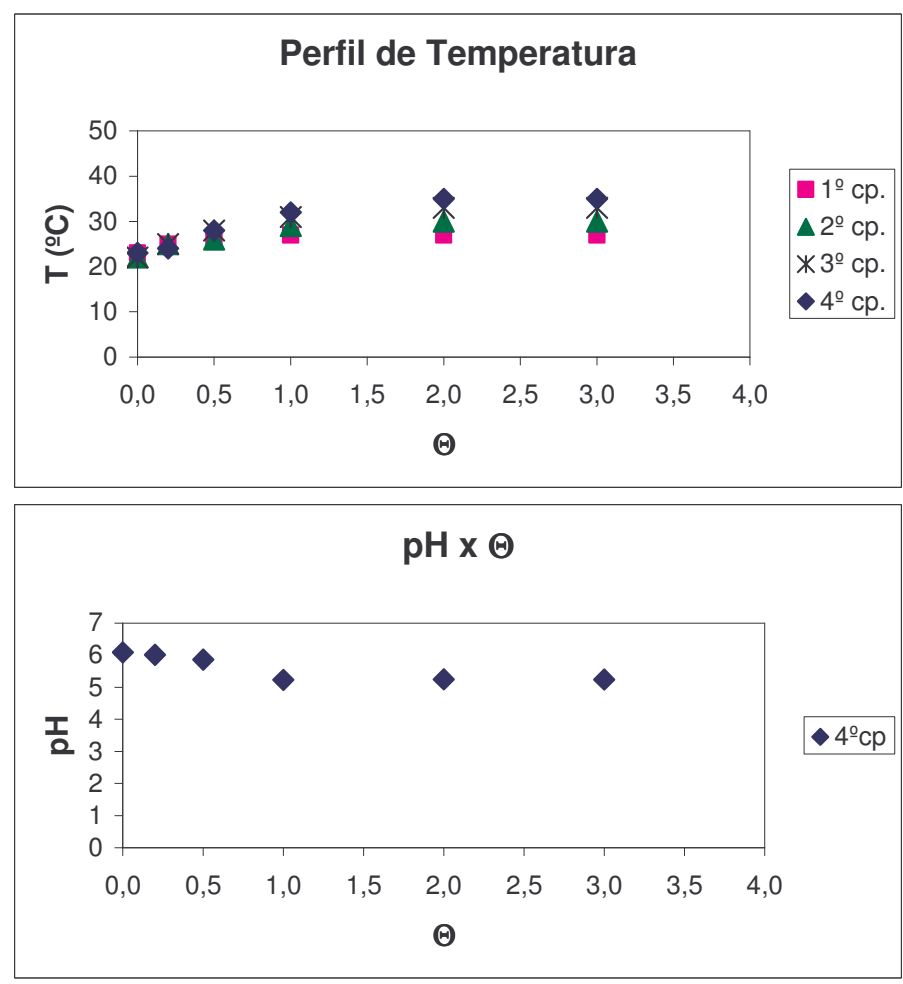

\section{Curva de Remoção de COT}
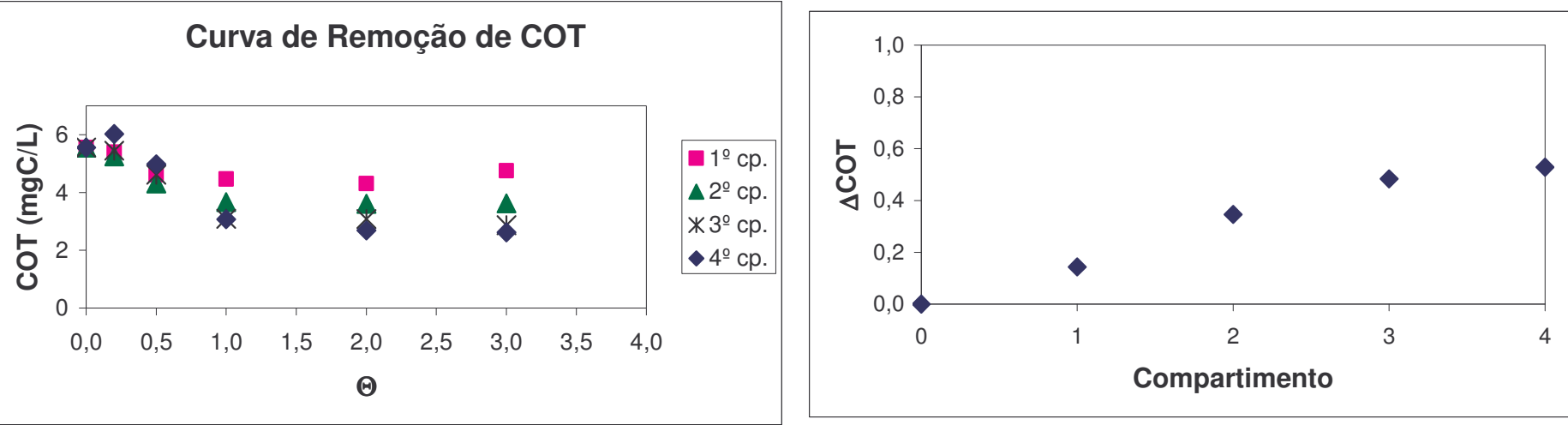

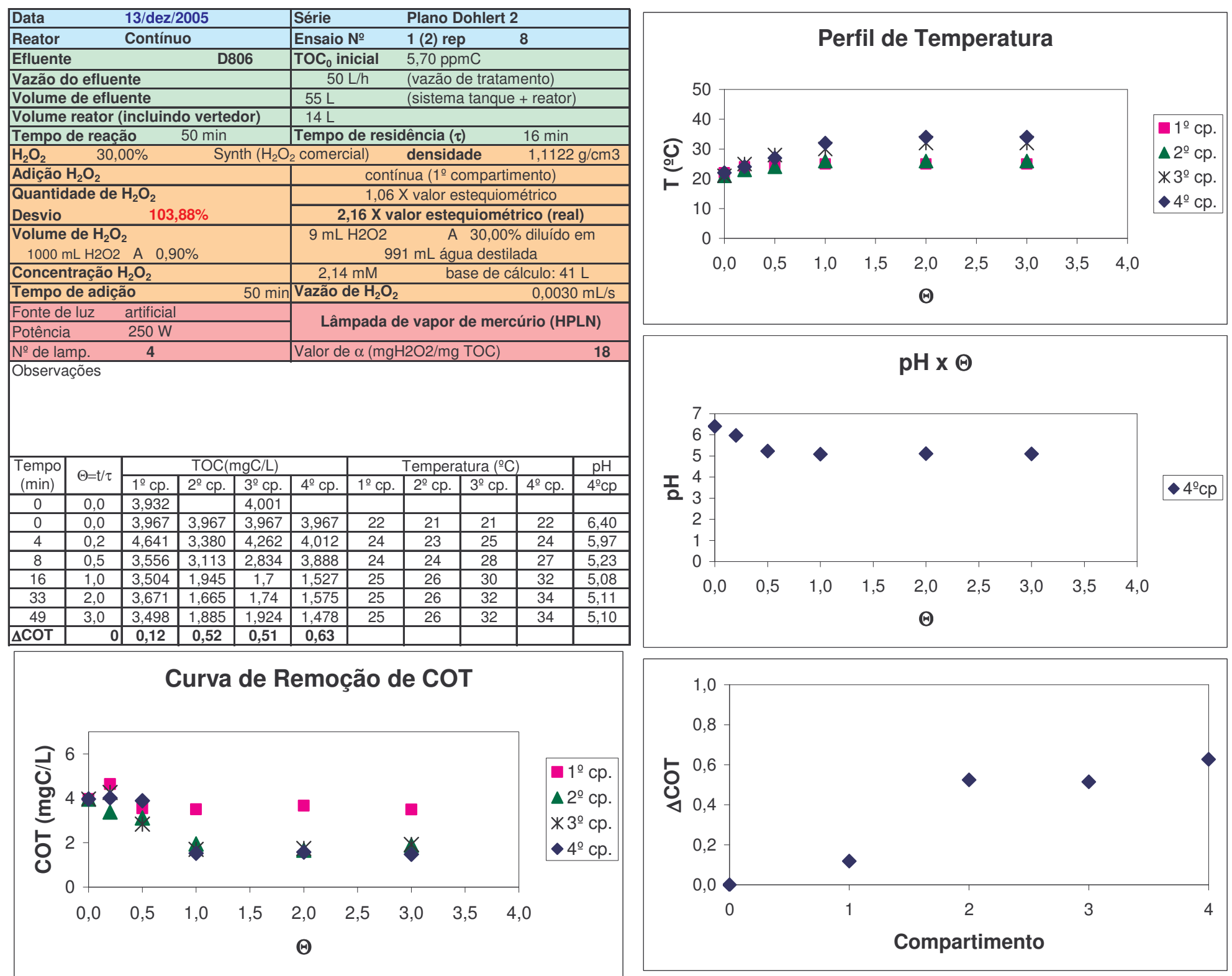

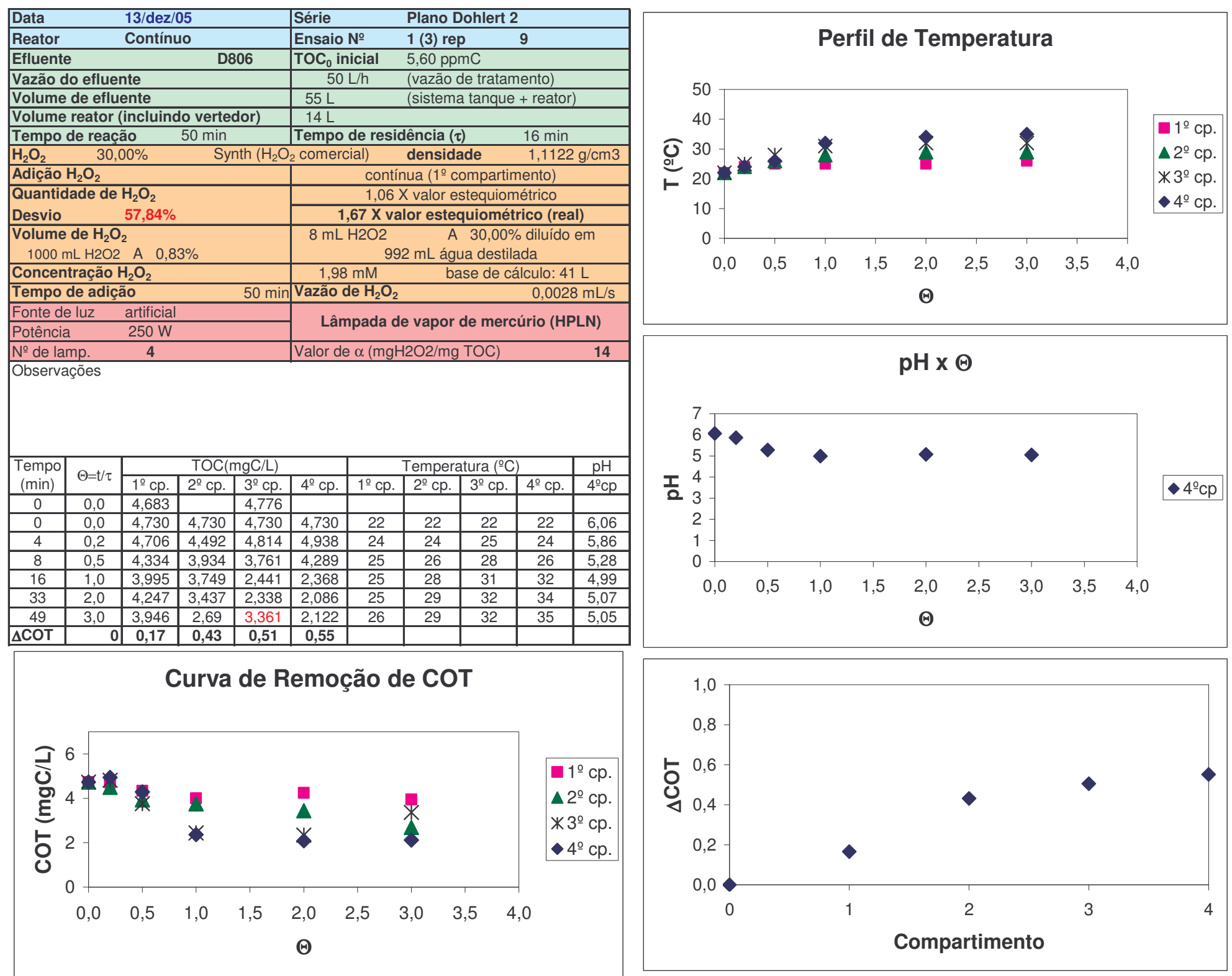

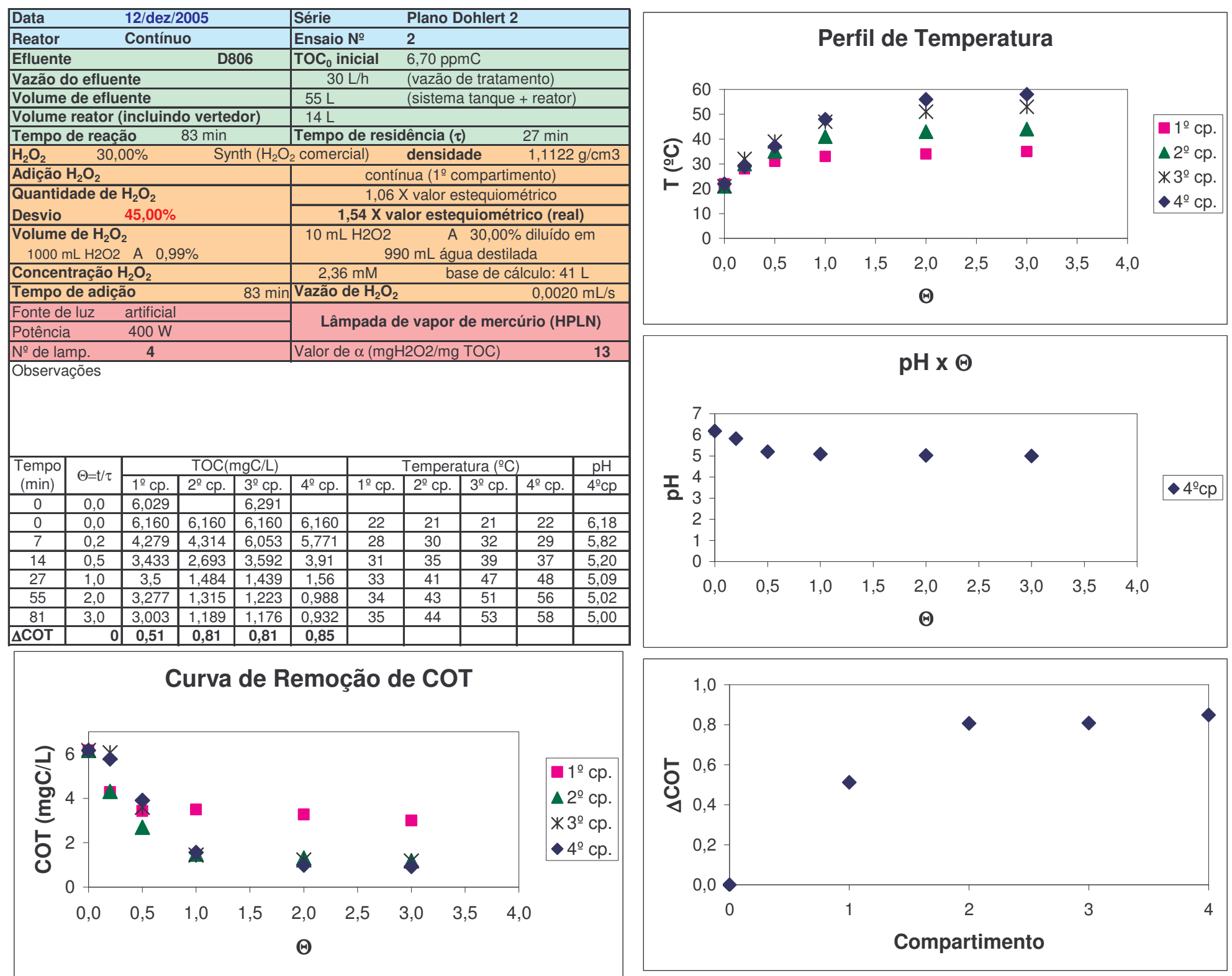

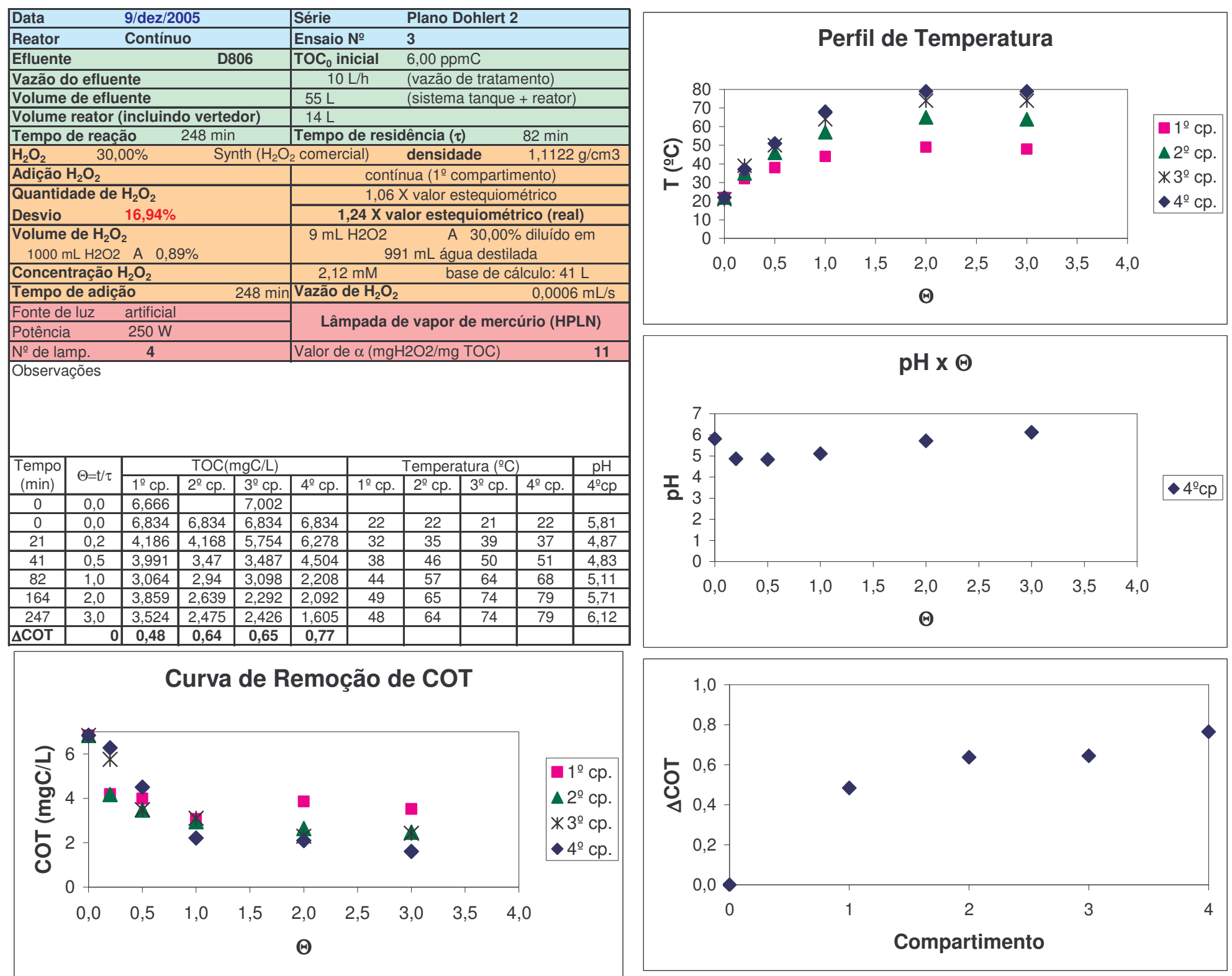

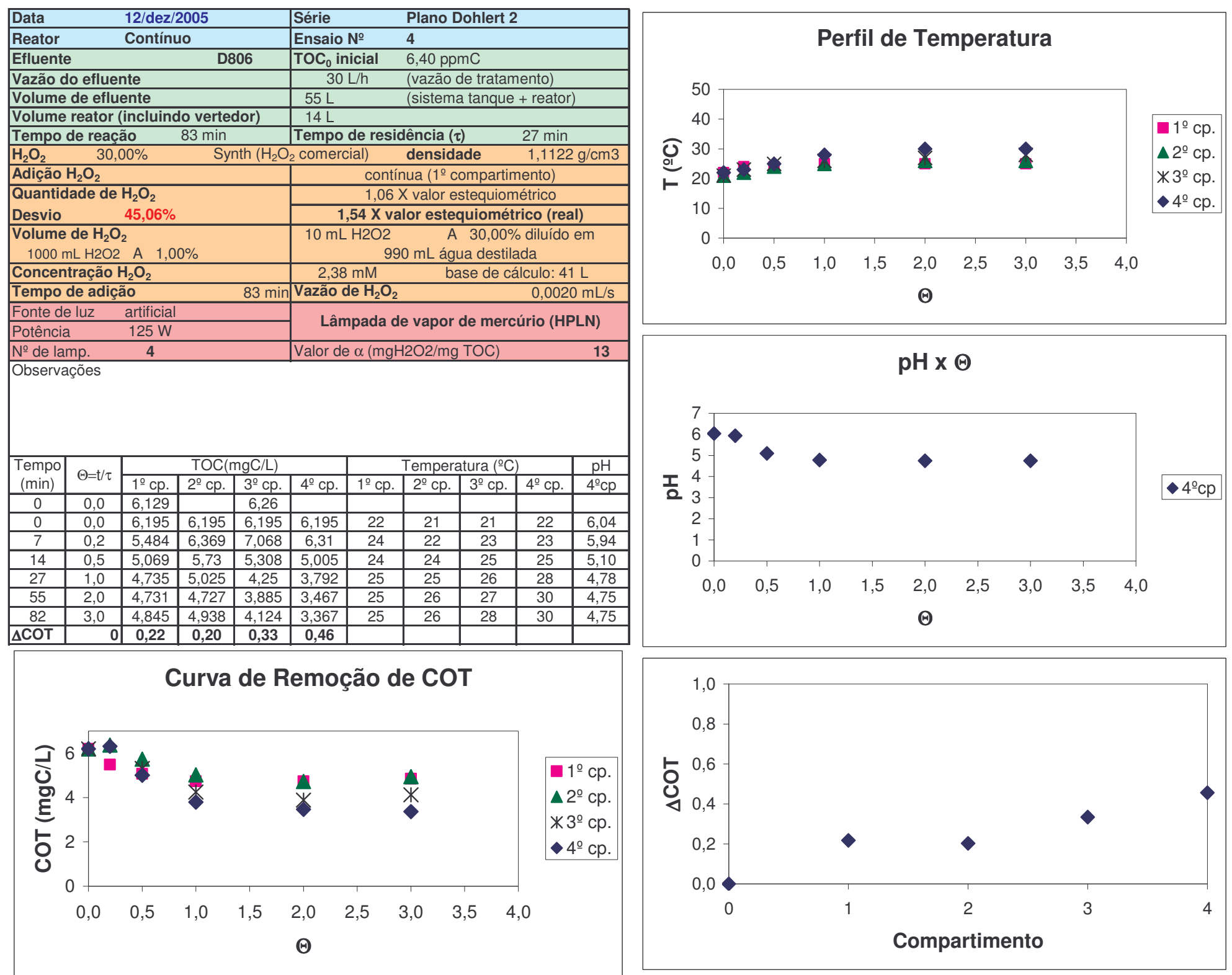

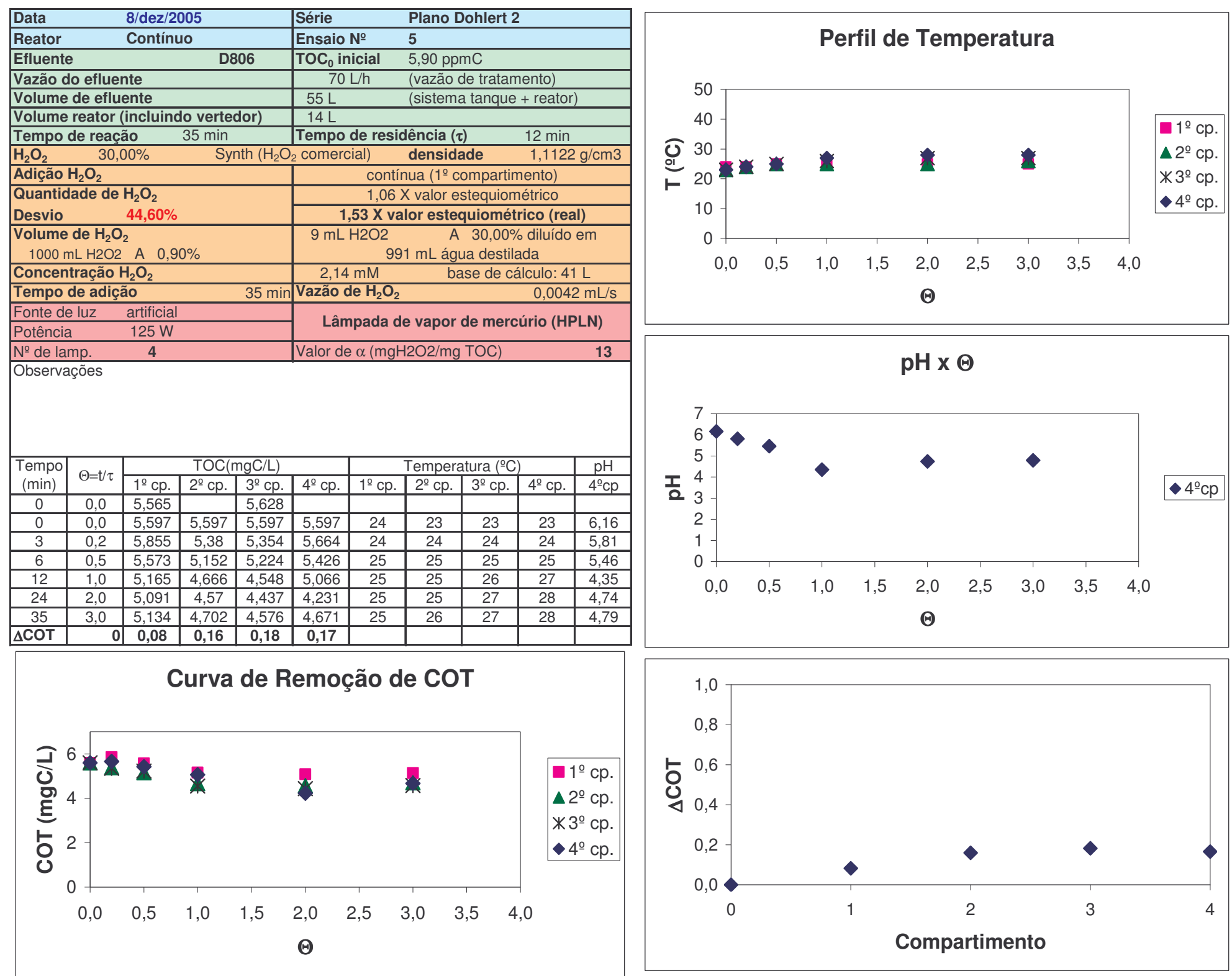

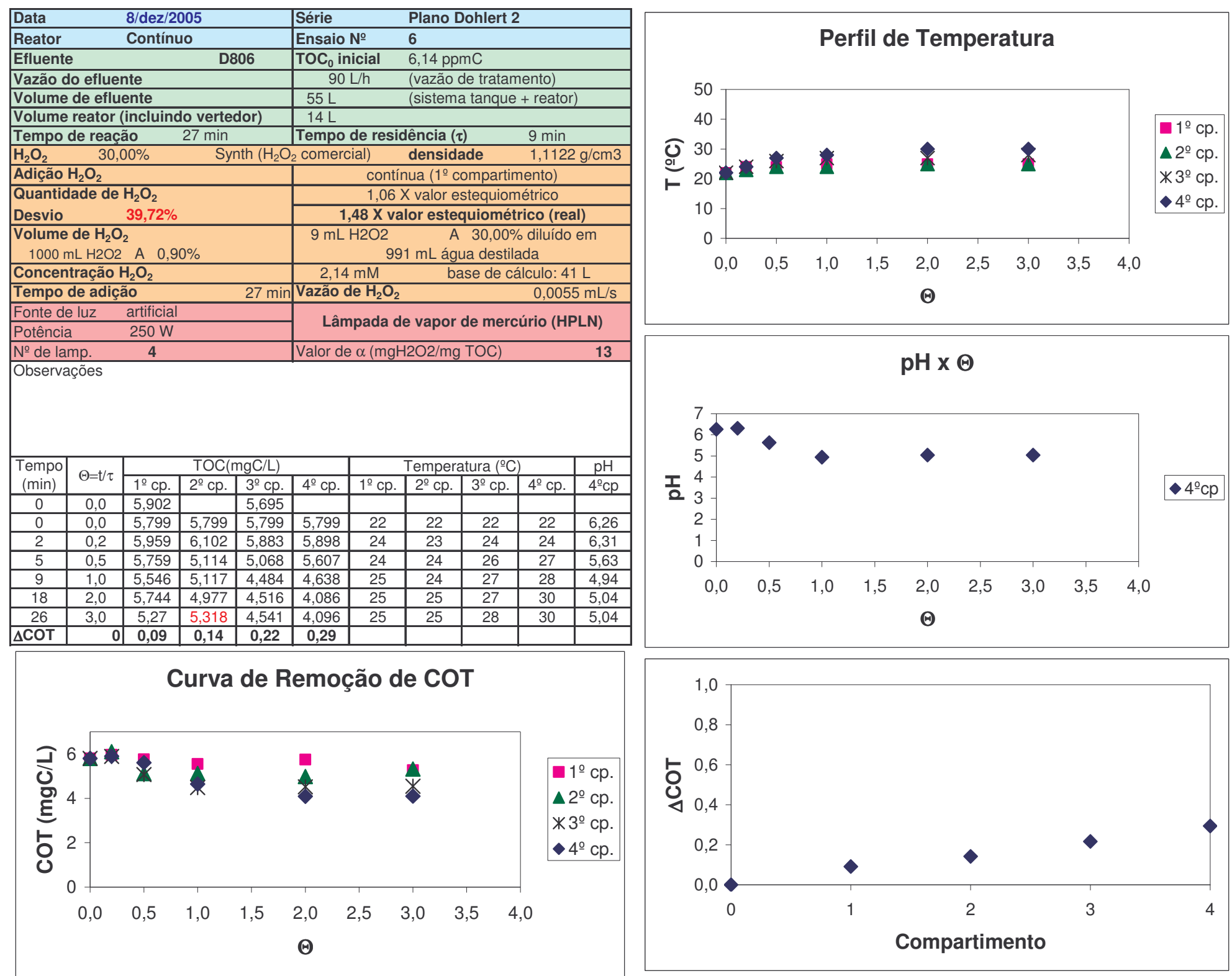

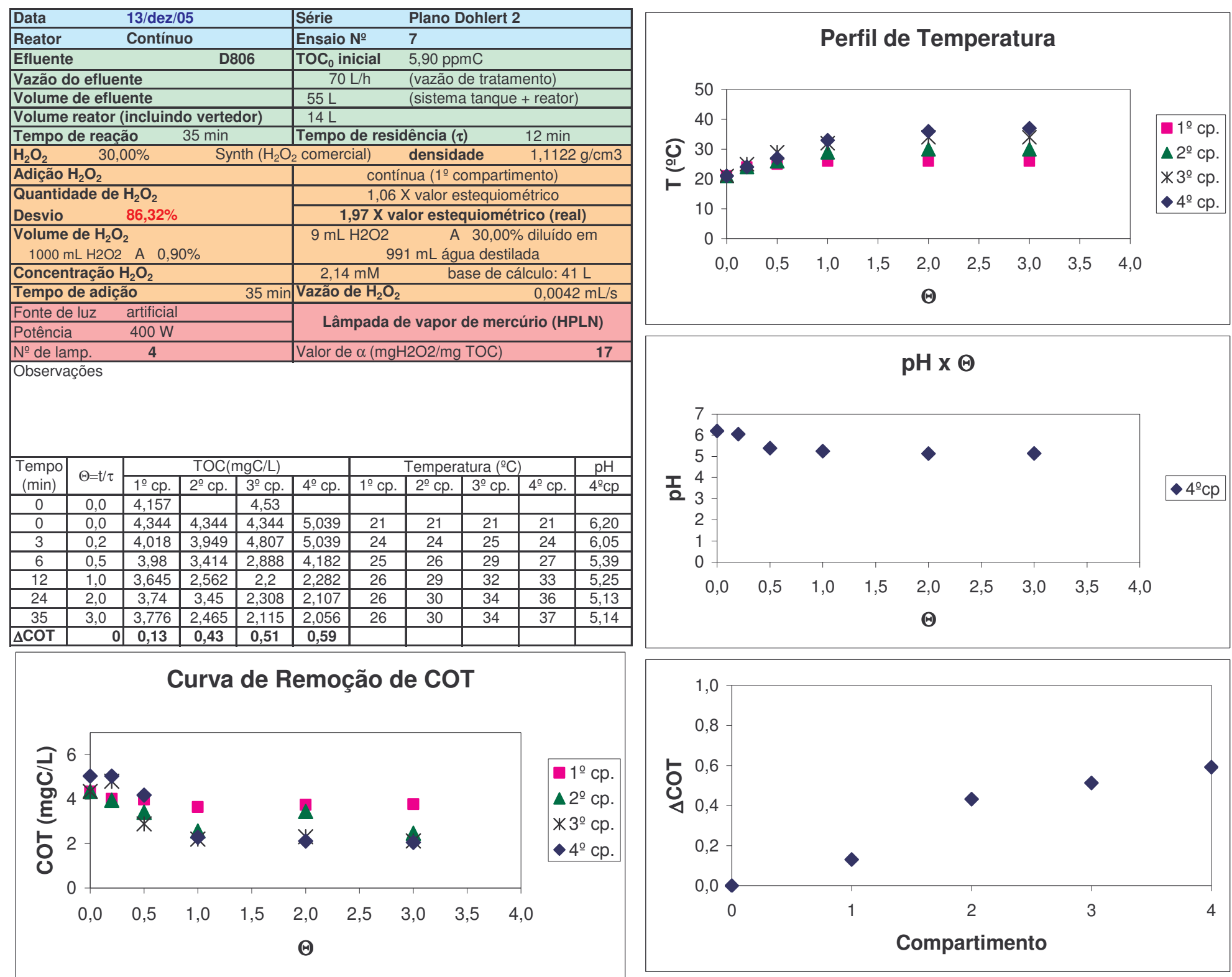